\title{
Radioactive Waste Management in the USSR: A Review of Unclassified Sources, 1963-1990
}

\author{
D. J. Bradley \\ K. J. Schneider
}

March 1990
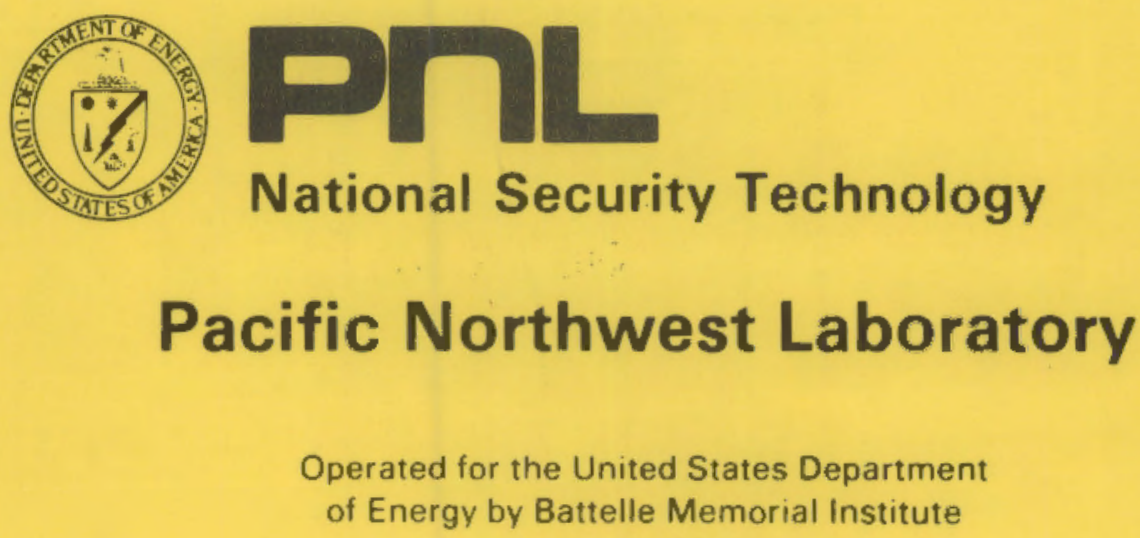

Prepared for the U.S. Department of Energy Office of Defense Programs under Contract DE-AC06-76RLO 1830

by

Office of National Security Technology Pacific Northwest Laboratory

Richland, Washington 99352 


\title{
DISCLAIMER
}

This report was prepared as an account of work sponsored by an agency of the United States Government. Neither the United States Government nor any agency thereof, nor Battelle Memorial Institute, nor any or their employees, makes any warranty, expressed or implied, or assumes any legal liability or responsibility for the accuracy, completeness, or usefulness of any information, apparatus, product, or process disclosed, or represents that its use would not infringe privately owned rights. Reference herein to any specific commercial product, process, or service by trade name, trademark, manufacturer, or otherwise does not necessarily constitute or imply its endorsement, recommendation, or favoring by the United States Government or any agency thereof, or Battelle Memorial Institute. The views and opinions of authors expressed herein do not necessarily state or reflect those of the United States Government or any agency thereof.

\author{
PACIFIC NORTHWEST LABORATORY \\ operated by \\ BATTELLE MEMORIAL INSTITUTE \\ for the \\ UNITED STATES DEPARTMENT OF ENERGY \\ under Contract DE-AC06-76RLO 1830
}

\section{AVAILABLE FROM NTIS}

DE91 007921

PNL-7182 (DE91 007921)

Radioactive Waste Management in the USSR: A Review of Unclassified Sources, $1963-1990$.

DJ Bradley, KJ Schneider

March 1990

PNL -7645

Radioactive Waste Management in the USSR: A Review of Unclassified Sources, Volume II.

DJ Bradley

March 1991

(Sent to OSTI)

PNL-8074

Radioactive Waste Management in the Former USSR: Volume III. DJ Bradley 
RADIOACTIVE WASTE MANAGEMENT IN THE USSR:

A REVIEW OF UNCLASSIFIED SOURCES, 1963-1990

D. J. Bradiey

K. J. Schneider

March 1990

Prepared for

the U.S. Department of Energy

under Contract DE-ACO6-76RLO 1830

Pacific Northwest Laboratory

Richland, Washington 99352 



\section{EXECUTIVE SUMMARY}

The Soviet Union operates a vast and growing radioactive waste management system. Detailed information on this system is rare and a general overal1 picture only emerges after a review of a great deal of literature. Poor waste management practices and slow implementation of environmental restoration activities have caused a great deal of national concern. The release of information on the cause and extent of an accident involving high-level waste at the Kyshtym production reactor site in 1957, as we11 as other contamination at the site, serve to highlight past Soviet waste management practices. As a result, the area of waste management is now receiving greater emphasis, and more public disclosures.

Little is known about Soviet waste management practices related to uranium mining, conversion, and fuel fabrication processes. However, releases of radioactive material to the environment from uranium mining and milling operations, such as from mill tailings piles, are causing public concern.

Official Soviet policy calls for a closed fuel cycle, with reprocessing of power reactor fuel that has been cooled for five years. For power reactors, only WVER-440 reactor fuel has been reprocessed in any significant amount, and a decision on the disposition of RBMK reactor fuel has been postponed indefinitely. Soviet reprocessing efforts are falling behind schedule; thus longer storage times for spent fuel will be required, primarily at multiple reactor stations.

Information on reprocessing in the Soviet Union has been severely limited until 1989, when two reprocessing sites were acknowledged by the Soviets. A 400-metric ton (MT) per year reprocessing facility, located at kyshtym, has been operational since 1949 for reprocessing production reactor fuel. This facility is reported to have been reprocessing WVER-440 and naval reactor fue 1 since 1978, with about 2000 MT of WVER-440 fuel being reprocessed by July 1989. A second facility, located near Krasnoyarsk and having a $1500 \mathrm{MT}$ per year capacity as the first of several modules, was about $30 \%$ completed by July 1989. The completion of this plant was subsequently "indefinitely postponed." The initial reprocessing scheme at the Kyshtym site used sodium uranyl acetate 
precipitation from fuel dissolved in nitric acid solutions. The basic methodology now appears to be based on the conventional PUREX process. Dry reprocessing on a pilot or laboratory scale has been under way in Dimitrovgrad since 1984, and a larger unit is now being built, according to the French CEA.

Perhaps significantly, much research is being done on partitioning high-level waste into element fractions. The Soviets appear to have the technology to remove radioactive noble gases released during reprocessing operations; however, there are no indications of its implementation.

Millions of curies of liquid low- and internediate-level wastes have been disposed of by well injection into underground areas where they were supposedly contained by watertight rock strata. Sone gaseous wastes were also disposed of by well injection. This practice is not referred to in recent literature and thus may not be widely used today. Rather, it appears that these waste streams are now first treated to reduce volume, and then solid ified using bitumen or concrete. These solidified liquid wastes from Soviet nuclear power reactor operations, along with solid wastes, are disposed of in shallow-land burial sites located at most large power reactor stations. In addition, 35 shallow-land burial sites have been alluded to by the Soviets for disposal of industrial, medical, and research low-level wastes as well as ionization sources. Research on tritium-bearing and other gaseous wastes is mentioned, as well as a waste minimization program aimed at reducing the volume of waste streams by $30 \%$.

The Soviets have announced that their high-level waste management plan is to 1) store liquid wastes for 3-5 years; 2) incorporate the waste into glass (at a final glass volume of 100-150 1iters/MT of fuel reprocessed); 3 ) set it aside in air-cooled storage for 30-50 years; and 4) provide for its final disposal in a deep geologic repository.

High-level waste solidification research started in the $1950 \mathrm{~s}$, and a pilot vitrification facility has operated for 10 years at Kyshtym. A fully radioactive unit also operated there for about two years until 1988 and produced 160 MT of HLW phosphate glass, containing $3.9 \times 10^{6}$ curies of radioactivity. [This corresponds to radioactivity in about $10 \mathrm{MT}$ of 10 -year-old power reactor fuel.] Problems with the glass melter electrodes have caused 
this latter plant to shut down, but a new design and plant are being developed. A site near Krasnoyarsk has also recently been referred to as a disposal site for low- and intermediate-level waste streams and possibly for vitrified wastes from Kyshtym.

Deep geologic disposal of vitrified high-level waste has been studied, at a modest level of effort, over the last decade in the Soviet Union. Key disposal concepts under consideration include mining shafts, deep drill holes, and underground excavations. Although a variety of host rock types have been addressed, the emphasis appears to be on salt, clay, and granite. The Soviet Union appears to require the use of man-made barriers and waste packages in permanent disposal, but the geologic formation will be relied upon as the primary protective barrier. The construction schedule for a Soviet repository has not been stated. Meanwhile, a decision on the first repository site may be made in 1990, with a candidate site being at Chelyabinsk. 



\section{ACKNOWLEDGMENTS}

This document was prepared for the U.S. Department of Energy, Defense Programs. The authors wish to thank and acknowledge Elizabeth K. Vaden, Project Manager, DOE Defense Programs, for providing programmatic guidance and reviews, and Ron Nelson, DOE Defense Programs, for technical reviews. Their input contributed significantly to the completion of the report.

The editorial review prior to publication was provided by David $R$. Payson, Pacific Northwest Laboratory. 

GLOSSARY OF ABBREVIATIONS - GENERAL TERMS

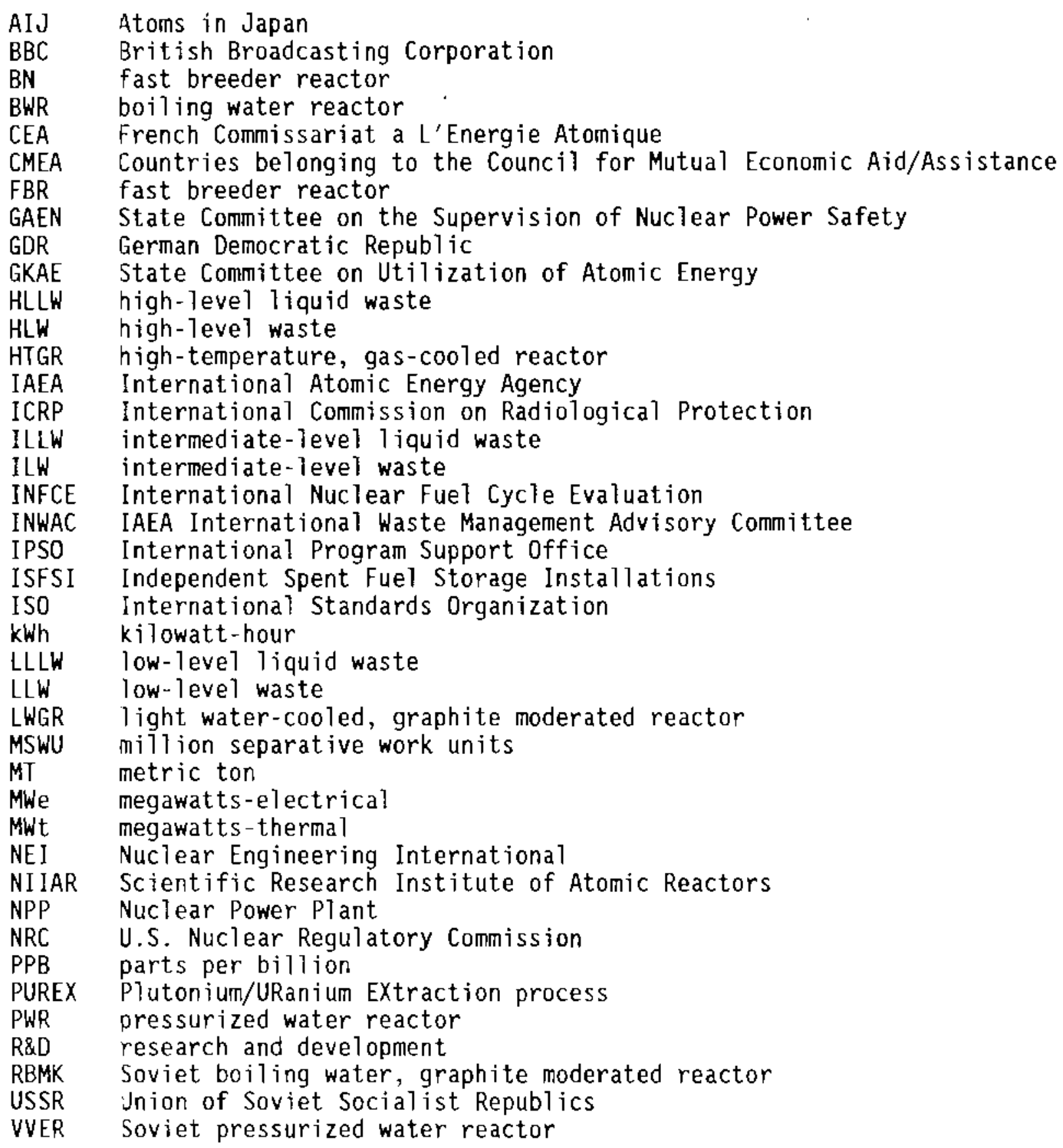





\section{CONTENTS}

EXECU"IVE SUMMARY . . . . . . . . . . . . . . . . . . . . . . i i

ACKNOWLEDGMENTS . . . . . . . . . . . . . . . . . . . . . . . . vii

GLOSSARY OF ABBREVIATIONS - GENERAL TERMS . . . . . . . . . . . . . . ix

INTRODUCTION AND SCOPE . . . . . . . . . . . . . . . . . . . . . . 1

1.0 FADIOACTIVE WASTE MANAGEMENT SUMMARY AND CLASSIFICATION $\ldots \ldots$

.1 POLICY AND STRATEGY . . . . . . . . . . . . . . . . . . . . 1.1

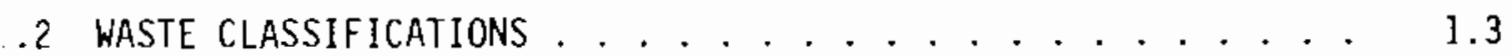

2.0 INSTITUTIONAL STRUCTURE . . . . . . . . . . . . . . . . . . 2.1

2.1 SUMMARY . . . . . . . . . . . . . . . . . . . . . . . . 2.1

2.2 KEY WASTE MANAGEMENT RESEARCH AND DEVELOPMENT INSTITUTIONS $\quad 2.4$

2.2.1 High-Level Waste Management Facilities. . . . . . . 2.4

2.2.2 Low- and Intermediate-Level Waste Management

Facilities . . . . . . . . . . . . . . . . . . 2.4

3.0 INTERNATIONAL EXCHANGES AND AGREEMENTS ON WASTE MANAGEMENT . . . . 3.1

3.1 SUMMARY . . . . . . . . . . . . . . . . . . . . 3.1

3.2 COOPERATION WITH OTHER COUNTRIES . . . . . . . . . . . . . 3.1

3.3 COOPERATION WITH THE UNITED STATES . . . . . . . . . . . . 3.4

4.0 WASTE MANAGEMENT IN THE FRONT END OF THE NUCLEAR FUEL CYCLE.. .4 .1$

4.1 SUMMARY . . . . . . . . . . . . . . . . . . . . . . . 4.1

4.2 POLICY AND STRATEGY . . . . . . . . . . . . . . . . . . . . . 4.1

4.3 WASTE MANAgEMENT ACTIVITIES . . . . . . . . . . . . . . . 4.2

5.0 iHCLEAR REACTOR OPERATIONS WASTE MANAGEMENT . . . . . . . . . . . 5.1

5.1 SUMMARY . . . . . . . . . . . . . . . . . . . . . . . . 5.1

5.2 POLICY AND STRATEGY . . . . . . . . . . . . . . . . . . . 5.1 
5.3 REACTOR WASTE MANAGEMENT . . . . . . . . . . . 5.2

5.3.1 Systems and Activities . . . . . . . . . . . 5.2

5.3.2 Waste Quantities............. 5.5

5.3.3 Research and Development . . . . . . . . 5.6

5.3 .4 Cost Information . . . . . . . . . . 5.6

5.3.5 Safety and Quality Assurance .......... . . 5.7

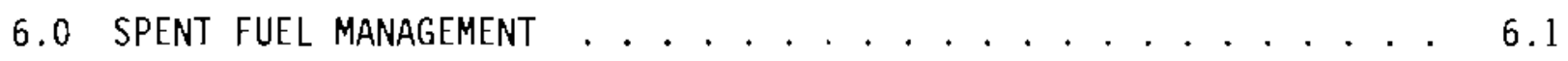

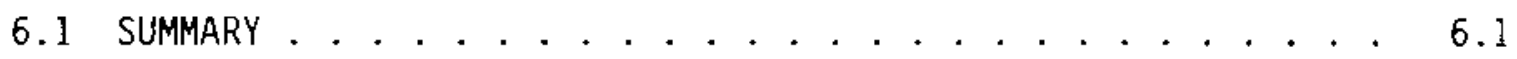

6.2 POLICY AND STRATEGY . . . . . . . . . . . . . . 6.1

6.3 SPENT FUEL QUANTITIES AND CHARACTERISTICS . . . . . . . 6.2

6.4 REACTOR SPENT FUEL STORAGE . . . . . . . . . . . . 6.4

6.4 .1 WVER Reactors ............. 6.4

6.4 .2 RBMK Reactors . . . . . . . . . . 6.6

6.4 .3 Fast Reactors . . . . . . . . . . . 6.6

6.4 .4 CMEA Countries . . . . . . . . . . . . . . 6.8

6.4 .5 0perations and 0ther Information ....... 6.8

6.4 .6 Research and Development . . . . . . . . . 6.9

6.5 INDEPENDENT SPENT FUEL STORAGE INSTALLATIONS . . . . . . 6.9

6.5.1 Facility Deveiopment and Locations. . . . . . . 6.9

6.5 .2 VVER Spent Fuel Storage .......... 6.10

6.5 .3 RBMK Spent Fuel Storage . . . . . . . . 6.11

6.5.4 0perations and 0ther Information........ 6.11

6.5.5 Research and Development .......... 6.12

6.6 MANAGEMENT OF THE NUCLEAR REACTOR ACCIDENT AT CHERNOBYL . . . 6.12

6.6 .1 Summary ................. 6.12

6.6.2 RBMK Fuel and Core Characteristics........ 6.13 
6.6.3 Character of Reactor Core Disruption ........ 6.14

6.6.4 Entombing Unit 4 for Localization of Damaged

Fuel and Radioactive Material ......... . 6.17

6.6.5 Radioactive Waste Management . . . . . . . . 6.18

6.6.6 Research Program to Assess Entombed Unit 4

Condition and Core Debris Behavior . . . . . . . 6.21

6.6.7 Cancellation of Units 5 and $6 \ldots \ldots . \ldots . . . . .61$

6.6 .8 Impacts on Local Public . . . . . . . . . . 6.22

6.6.9 Cost of Accident Recovery . . . . . . . . . . 6.24

7.0 FUEL REPROCESSING (Excluding High-Level Waste Processing and

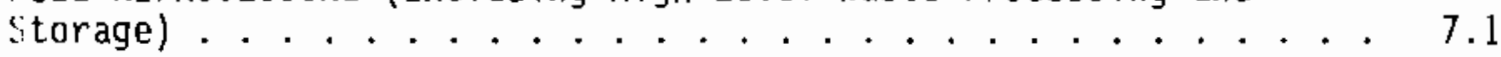

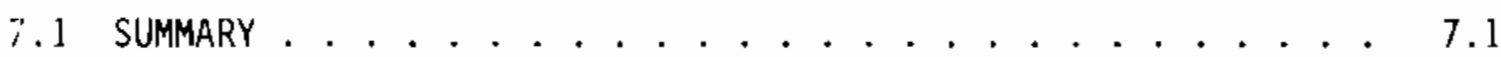

7.2 POL ICY AND STRATEGY . . . . . . . . . . . . . . . 7.2

7.3 FUEL REPROCESSING FACILITIES AND SYSTEMS . . . . . 7.3

7.3.1 Facility Types and Characteristics........ . 7.3

7.3.2 Research and Development . . . . . . . . . 7.7

7.4 . FUEL REPROCESSING WASTE MANAGEMENT $\ldots \ldots \ldots \ldots . \ldots 7.8 \ldots$

7.4.1 Systems and Activities . . . . . . . . . . . . 7.9

7.4 .2 Research and Development.......... 7.9

8.0 HIGH-LEVEL Liquid WASTE PROCESSING AND STORAGE . . . . . . . . 8.1

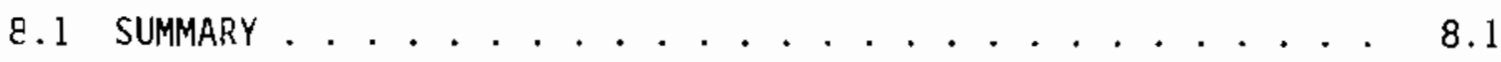

8.2 POLICY AND STRATEGY . . . . . . . . . . . . . . 8.2

8.3 HIGH-LEVEL WASTE QUANTITIES . . . . . . . . 8.2

$\varepsilon .4$ HIgh-LeVEL Liquid WAStE tReAtMent and StORAGE . . . . . . 8.2

8.4.1 Facjlities and Systems ............ 8.2

8.4.2 Research and Development . . . . . . . . . 8.4

8.5 HIGH-LEVEL LIQUID WASTE SOLIDIFICATION AND INFERIM

STORAGE . . . . . . . . . . . . . . . . . 8.5 
8.5.1 Solidification Facilities and systems . . . . . 8.5

8.5.2 Solidified High-Level Waste Stcrage Facilities and Systems . . . . . . . . . . . 8.17

8.6 COST INFORMATION . . . . . . . . . . . . . . 8.19

8.7 ACCIDENT IN THE URALS, $1957 \ldots \ldots . \ldots . \ldots . \ldots$

8.7.1 Summary ................. 8.20

8.7.2 Background and History............ 8. 8.20

8.7.3 Accident Cause and Waste Management Activities... 8 8.24

9.0 LOW-LEVEL AND INTERMEdIATE-LEVEL WASTE CONCITIONING AND STORAGE $\quad 9.1$

9.1 SUMMARY . . . . . . . . . . . . . . . . . . . . 9.1

9.2 POLICY AND STRATEGY . . . . . . . . . . . . . . . . . 9.1

9.3 LOW-LEVEL AND INTERMEDIATE-LEVEL WASTE QUANTITIES . . . . . 9.2

9.4 LOW-LEVEL WASTE TREATMENT AND STORAGE . . . . . . . 9.3

9.4.1 Treatment Facilities and Systenls........ 9.4

9.5 INTERMEDIATE-LEVEL WASTE TREATMENT ANC STORAGE . . . . . 9.10

9.5.1 Treatment Facilities and Systems . . . . . . . . 9.10

9.5.2 Storage Facilities and Systems ......... 9.11

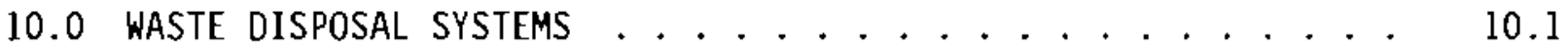

10.1 SuMMARY $\ldots \ldots \ldots . \ldots \ldots . \ldots . \ldots . \ldots . \ldots$

10.2 POLICY AND STRATEGY . . . . . . . . . . . 10.2

10.2.1 High-Level Waste Disposal Systems ....... 10.2

10.2.2 Low-Level and Intermediate-Level Waste
Disposal Systems .............. 10.3

10.3 HIGH-LEVEL WASTE DISPOSAL SYSTEMS . . . . . . . . . 10.4

10.3.1 Site Selection .............. 10.4

10.3.2 Concept and Facility Description ....... 10.5

10.3.3 Research and Development ........ 10.7 
10.4 LOW-LEVEL AND INTERMEDIATE-LEVEL WASTE DISPOSAL SYSTEMS . 10.8

10.4.1 Site Selection ............. 10.8

10.4.2 Concept and Facility Description ....... 10.10

10.4.3 Research and Development ......... 10.13

10.4.4 Cost Information ............. 10.15

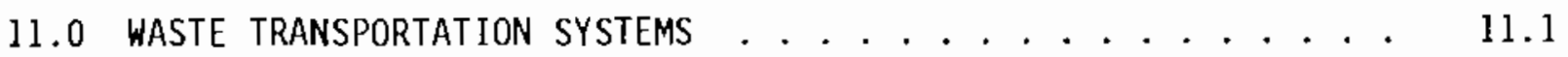

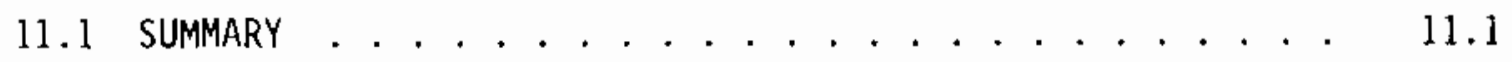

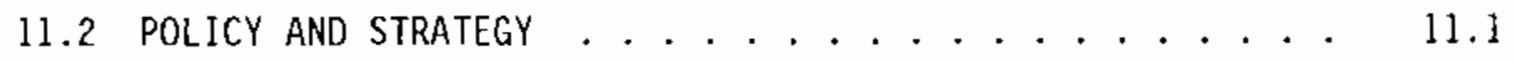

11.3 SPENT FUEL TRANSPORTATION SYSTEM . . . . . . . . . 11.2

11.3.1 Packaging and Hardware System ........ 11.2

11.3.2 Cask Decontamination ........... 11.5

11.3.3 Management, Operations and Capabilities..... 11.5

11.3.4 Research and Development ......... 11.6

11.3.5 Safety and Quality Assurance ......... 11.6

11.4 LOW- AND INTERMEDIATE-LEVEL WASTE TRANSPORTATION SYSTEM . 11.7

12.0 REFERENCES . . . . . . . . . . . . . . . . . 12.1

APPENDIX A - BACKGROUND INFORMATION ............ A.I

A1.0 INSTITUTIONAL StRUCTURE: KEY MINISTRIES AND STATE COMMITTEES . . A.1

A2.0 SOVIET NUCLEAR ENERGY . . . . . . . . . . . . . . . . A.6

A3.0 NUCLEAR ENERGY FACILITIES . . . . . . . . . . . . . . A.12

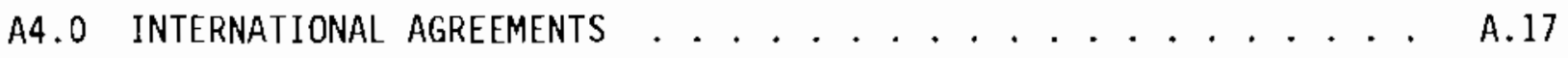

A5.0 Mining AND MILLING OPERATIONS . . . . . . . . . . A.22

A6.0 URANIUM CONVERSION, ENRICHMENT AND FUEL FABRICATION . . . . . A.27

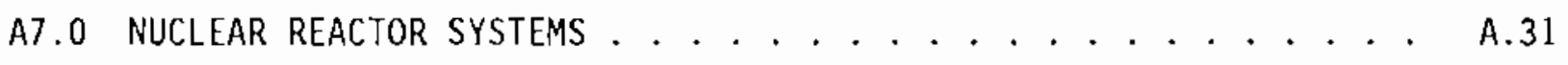

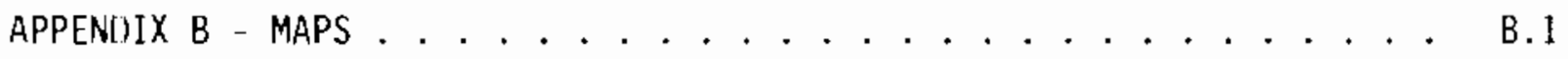


APPENDIX $C$ - CHART OF SOVIET WASTE MANAGEMENT ACTIVITIES ACROSS

THE NUCLEAR FUEL CYCLE . . . . . . . . . . . . . . . . . C.l

INDEX. . . . . . . . . . . . . ............ I. I 


\section{EIGURES}

1.1 General USSR Nuclear Fuel Cycle Schematic . . . . . . . . 1.2

6.1 Estimated Spent Fue Discharged from WWER and RBMK Reactors . . 6.4

8.1 High-Level Liquid Waste Solidification Processes . . . . . . 8.6

8.2 Diagram of HLW Ceramic Melter Vitrification Facility . . . . 8.10

Al.1 Nuclear Safety Regulatory Bodies and Publications in the USSR . A.5

A7.1 USSR Yearly Nuclear Power Generation Capacity . . . . . . . . A.57

A7.2 L'SSR Cumulative Nuclear Power Generation Capacity: 1958-1989 . A A.58

B.l LSSR Uranium-Thorium Deposits and Processing Centers . . . . . . B.3

B.2 LSSR Active Nuciear Power Stations . . . . . . . . . B.5

B.3 LSSR Planned Nuclear Power Stations . . . . . . . . . . . . B.6

B.4 LSSR Decommissioned Nuclear Power Stations or Units . . . . . B.7 B.7

C.1 Chart of Soviet Waste Management Activities Across the Nuclear Fuel Cycle ..................... C.1 


\section{$\underline{\text { TABLES }}$}

1.1 General Stages of Soviet Plan for Handling Liquid Radioactive Wastes... . . . . . . . . . . . . . . . . 1.3

1.2 Classification of Liquid Radioactive Wastes in the USSR . . . . 1.3

1.3 Classification of Solid Radioactive Wastes in the USSR . . . . . 1.4

6.1 Typical Characteristics of Spent Fuel from Soviet WVER, RBMK and Fast (BN) Reactors ............... 6.3

6.2 Typical RBMK-1000 Design Data . . . . . . . . . . . . 6.14

6.3 Estimated Release of Radionuclides from the Chernobyl Accident . . 6.20

11.1 Characteristics of Some USSR Spent Fuel Transportation Casks . . 11.4

A4.1 Summary of USSR Internationa] Agreements . . . . . . . . . . . A.20

A7.1 Performance of Selected Soviet VVERs Through 1987 . . . . . . . A.34

A7.2 USSR Power Reactors - Operational and Shutdown . . . . . . . . . A.46

A7.3 USSR Power Reactors - Planned . . . . . . . . . . . . . A.49

A7.4 USSR Research and Test Reactors Built or Authorized . . . . . . . A.50

A7.5 USSR Power Reactors Stopped or Cancelled Since the Chernobyl \#4 Accident ........................ A1

A7.6 USSR Power Reactor History: Generation Capacity from 1958-1989 . A.53

A7.7 USSR Power Reactor History: Units On Line from 1958-1989 . . . A.54

A7.8 Countries with Reactors 0perating Using USSR-Supplied Fuel . . . . A.55 


\section{INTRODUCTION AND SCOPE}

fiadioactive waste materials--and the methods being used to treat, process, store, transport, and dispose of them--have come under greatly increased scrutiny over the last decade in both national and international fora. Nuclear power has reached the stage where further development will be constrained until the public is satisfied that waste disposal issues are being decisively addressed. As the operator of what is likely to become the world's largest nuclear waste management system, nuclear waste practices in the Soviet Union are of obvious interest. In particular, the Chernobyl accident demonstrated that what happens in the Soviet nuclear program can have serious implications for the U.S. nuclear program.

This report was prepared in an effort to gain a better understanding of the Soviet radioactive waste management program. It may be useful in assessing potential effects on the U.S. nuclear program, as well as providing background material for bilateral discussions on nuclear waste management practices.

The scope of this study covers all publicly known radioactive waste management activities in the Soviet Union as of March 1990, and was based on a review of unclassified literature including documents, meeting presentations, and data base searches of worldwide press releases. The study focuses primarily on waste management activities from spent fuel management through disposal of all waste types; however, available waste management information is given for activities in the front end of the fuel cycle such as mining and power reactor waste management. Background information on fuel cycle activities and power reactors is also provided in appendixes.

The assessment of the Soviet waste management program is not complete in that there are many gaps in the open Titerature related to specific facilities and practices. The reader should recognize that most information relates to currert policy, while historically, practices may have been quite different. In adcition, translation difficulties may have resulted in some inconsistencies. 
Information is given as presented in the references, with supporting analyses or inferences by the authors given in brackets [], when sufficient information was available to assure the analyses are correct. In some cases, the same information is given in more than one pilace in the report, where the information is pertinent to the respective report sections. 


\subsection{RADIOACTIVE WASTE MANAGEMENT SUMMARY AND CLASSIFICATION}

This section presents a summary of available information on the Soviet strategy for nuclear waste management and the classification of waste streams.

\subsection{POLICY AND STRATEGY}

Proper management of radioactive wastes produced by nuclear power plants and fuel reprocessing facilities is an important subject of the Soviet program of nuclear research and development (Semenov 1983). Figure 1.1 shows the general nuclear fuel cycle scheme for the Soviet Union from which radioactive waste management activities arise (CIA 1985). The fuel cycle is a conventional closed one with the feed materials production serving both defense and power activities and the flow of materials from power reactor fuel reprocessing to defense activities. The product stream(s) involved in this transfer are not known. A detailed description of waste management activities across the Soviet nuclear fuel cycle is depicted in Appendix C, Figure C.1.

The Soviet Union has stated that its general plan for handling all levels of liquid radioactive wastes is divided into six general stages, shown in Table 1.1 .

Long-term radioactive waste management plans in the Soviet Union include solidification of high-level waste (HLW) followed by dry storage until a repository is ready, and conditioning of low-level waste (LLW) and intermediate-level waste (ILW) followed by shallow-land disposal. Interim storage of solidified intermediate-level wastes is planned prior to disposal (Semenov 1983); however, it has been acknowledged that 10w- and intermediate-level wastes have been disposed of by injection into wells from the $1960 \mathrm{~s}$ at least through 1980 (GKAE 1978 p. 9-10; Kondratyev 1976; Spitsyn 1978; BBC 8/1/80). Placing solidified HLW [and possibly some ILW] in a deep geologic formation has been considered as the likely disposal method (Kedrovskiy et al. 1987) and a site for a $H L W$ repository may be identified next year (Nucleonics Week 10/89a). 


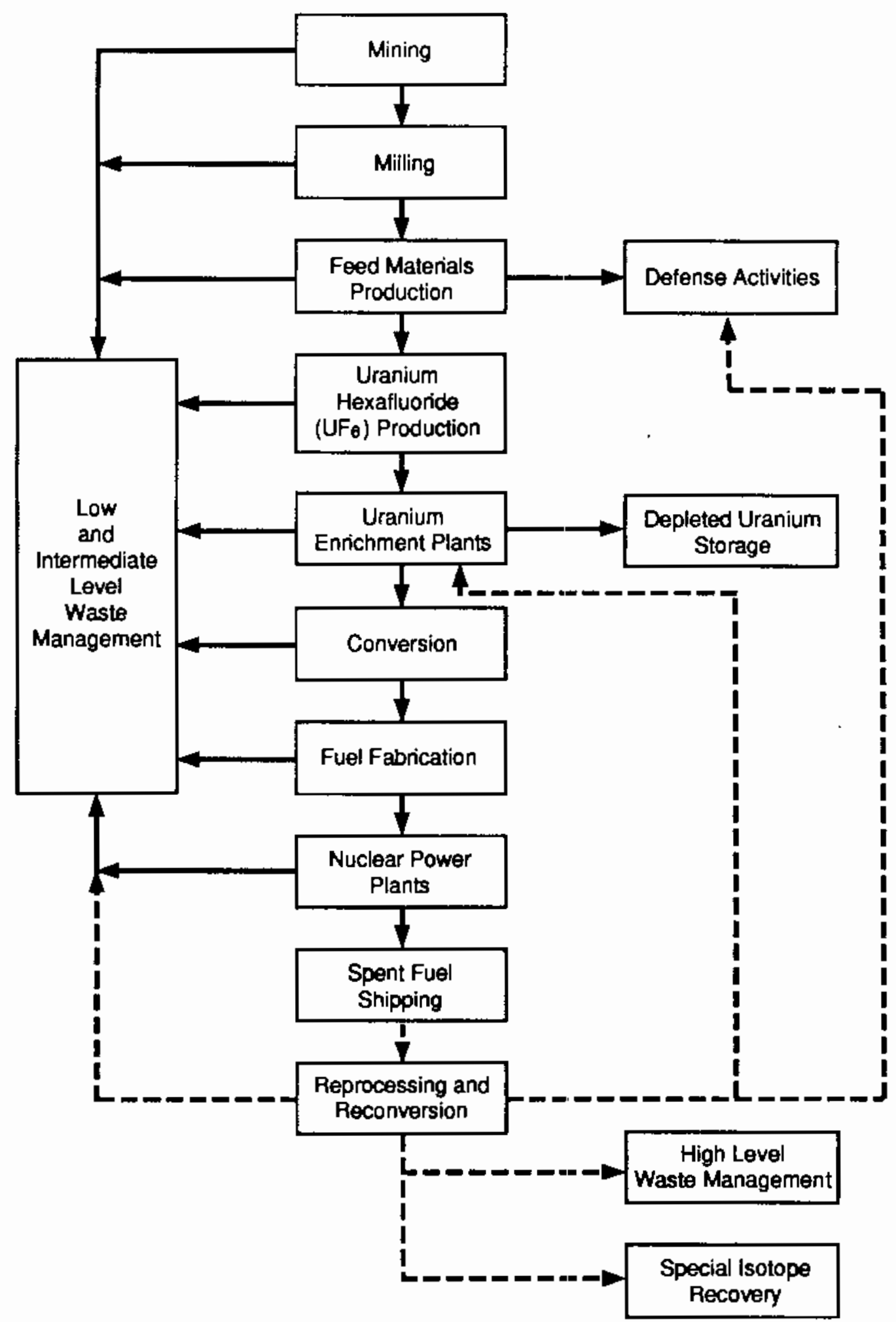

Note: The dotted lines indicate activities not done in the United States civilian program.

FIGURE 1.1 General USSR Nuclear Fuel Cycle Schematic 


\section{TABLE 1.1. General Stages of Soviet Plan for Handling Liquid Radioactive Wastes}

Stage I - collection and primary concentration

Stage II - temporary storage of concentrates in stainless steel tanks

Stage III - solidification of the concentrates formed during the processing of LLW, ILW and HLW

Stage IV - temporary storage of solidified waste in above-ground storage facilities

Stage V - transport of solidified waste to centralized or regional storage sites in special containers

Stage VI - final disposal of solidified waste at centralized or regional disposal sites (Sedov et al. 1983, 1988).

\subsection{WASTE CLASSIFICATIONS}

Liquid radioactive wastes are classified as LLW, ILW or HLW by the Soviets, depending on the radionuclide content. Transuranic wastes are not discussed and are presumed to be included in ILW. The classification scheme is given in Table 1.2 (Sedov et a). 1983). [The classification of liquid radioactive wastes is not comparable to a U.S. classification, which is based on solid wastes.]

Solid radioactive wastes are classified into three categories: Group I (LLW), Group II (approximately LLW to ILW), and Group III (approximately ILW to $H(W)$, depending on the radionuclide content and external radiation levels.

IABLE 1.2. Classification of Liquid Radioactive Wastes in the USSR (Sedov et a1. 1983)

\begin{tabular}{|c|c|}
\hline $\begin{array}{l}\text { Waste } \\
\text { Category }\end{array}$ & $\begin{array}{c}\text { Specific radioactivity, } \\
\text { Ci/liter }\end{array}$ \\
\hline Low-1 evel & less than $1 \times 10^{-5}$ \\
\hline Intermediate-level & from $1 \times 10^{-5}$ to 1 \\
\hline High-level & greater than 1 \\
\hline
\end{tabular}


This classification scheme is given in Table 1.3 (Sedov et al. 1983). [A] though not directly comparable, Group I wastes are roughly comparable to U.S. NRC LLW Class A, and Group II wastes are roughly comparable to NRC LLW Class C.]

IABLE 1.3. Classification of Solid Radioactive Wastes in the USSR(a) (Sedov et a1. 1983)

Gamma Dose Rate $10 \mathrm{~cm}$ from Surface Specific Beta Specific Alpha Category of Haste, $\mathrm{mrem} / \mathrm{h} \quad$ Activity, $\mathrm{Ci} / \mathrm{kq} \quad$ Activity, $\mathrm{Ci} / \mathrm{kg}$

Group I Less than 30 From $\begin{array}{r}2 \times 10^{-6} \\ 1 \times 10^{-4}\end{array}$ to From $2 \times 10^{-7}$ to

Group II From 30 to 1000 From $\begin{array}{r}1 \times 10^{-4} \text { to From } 1 \times 10^{-5} \\ 1 \times 10^{-1}\end{array}$ Group III Greater than 1000 Greater than
\[ 1 \times 10^{-1} \] Greater than
$1 \times 10^{-2}$

(a) Excludes solidified high-level wastes. 


\subsection{INSTITUTIONAL STRUCTURE}

Information on Soviet institutions associated with nuclear power and radioactive waste management is given in this section. This includes Ministries and State Committees as well as key research and development organizations.

\subsection{SUMMARY}

Research and development in the USSR is carried out by the Academy of Sciences and the federal branch ministries. The Academy of Sciences, founded at the start of the 18th Century by Peter the Great, has some $3001 \mathrm{ab}$ oratories, observatories and museums under its control. The bulk of the fundamental research is carried out in these institutions. As of 1987, the Academy was under pressure to undertake more applied research. Most applied R\&D, including nuclear energy, is carried out in the branch ministries, which receive about $80 \%$ of the available funding. About two-thirds of the personnel working in a given field are located in laboratories controlled by the branch ministries (Sinclair 1987).

The entire nuclear industry is currently undergoing major reorganization within the USSR as part of the reorganization of the Soviet government. Although it appears that this reorganization is not complete, what has been announced is included in this section. Information on the previous organization is included in Appendix A. The following institutional information came from Nucleonics Week $7 / 89 \mathrm{~b}$, except where noted.

The relatively young Ministry of Nuclear Power (Minatomenergo) has been subsumed into the previous defense-related Ministry of Medium Machine Building, the product now being known as the Ministry of Nuclear Power, Engineering \& Industry.

The venerable USSR State Committee for the Utilization of Atomic Energy (GKAE) is in a state of change. A senior official of the GKAE to?d Nucleonics Week that the government reorganization "is just getting started" and predicted that the decision on the future of the atomic energy committee will take "not less than a couple of months." GKAE previously was part of the structure of the medium machine-building ministry, and it is now being debated 
whether it should be preserved within the new nuclear industry ministry, whether it should be abolished, or be recreated in some other form. In the meantime, the senior official cited above said, "we have been instructed to behave and act as if nothing had happened."

The Soviet Union's nuclear regulatory body, the former State Committee for the Supervision of Safe Working Practices ir the Nuclear Power Industry (Gosatomenergonadzor, or GAEN), has become a "sliper-committee," as it also has been given responsibility for the safety of industries other than nuclear. The comittee's new name is the State Committee for the Supervision of Safe Working Practices in Industry \& the Nuclear Power Industry (Gospromatomnadzor). Vadim Malyshev, named GAEN head in 1986, continues as chairman of the new safety regulatory committee. In his address to the Soviet parliament, Malyshev said that a federal system for regulating industrial safety must be created and that his committee needs new legal powers to enforce preventive safety measures, "not fire brigades." The new committee's role covers safety of the general public, worker safety, and environmental protection.

The integration of the Nuciear Power Ministry, which was created after Chernobyl to operate the country's nuclear power plants but not to build them, into the former medium machine-building ministry (Minsredmach) appears designed to bring the Soviet Union's defense anc civilian nuclear engineering organizations under one disciplined roof. Minsredmach has always been in charge of nuclear component manufacturing and of the nuclear fuel cycle, notably for the defense sector.

The new Nuclear Engineering Minister, Vitaly Fedorovich Konovalov, approved July 4, 1989 by the USSR Supreme Soviet, stressed the importance of design and construction of "reliable and modern" defense-related equipment as a "leading theme" in his department's mission. He further stressed the importance of safety in nuclear power plant design ard construction. The new ministry will assume the operational responsibility for nuclear power piants formerly held by the Nuclear Power Ministry under Nikolai Lukonin. Konovalov, former Deputy Minister of Minsredmach and most recently in charge of milk production, also told the Supreme Soviet that the nuclear ministry is reducing 
production of uranium at its Navoi mining and enrichment complex so as to increase the complex's production of gold by several metric tons. Lev D. Ryabev, former head of Minsredmach, has also been promoted to Deputy Chairman of the USSR Council of Ministers, responsible for energy matters.

The reorganization brought a number of new ministers to the USSR Cabinet, among which is Yuri K. Semenov as Minister of Power \& Electrification. Semenov, age 57, is well-known internationally since he recently worked as Deputy Chairman of the USSR Council of Ministers' Bureau for the fuel and energy sector. In his speech to the Supreme Soviet, Semenov said that a priority of his ministry would be determining the optimum mix of nuclear, hydro. and fossil-fired power stations. He said in response to a question that soviet electricity exports are to grow from 40-billion $\mathrm{kwh} / \mathrm{yr}$ to about 54-billion kWh by 2000, and that Soviet power stations are expected to generate a total of 1.79-trillion kWh of electricity in 1989 (Nucleonics Week $7 / 89 b)$.

I.t was pointed out recently that "new processes and equipment for waste management," after discussion within the ministries and scientific technical boards, are approved by the State Committee for Nature Protection (State Sanitary Inspection - Gossannador), as well as local governments. Responsibilities for nuclear-related activities also must be in accord with the "Decree of the Supreme Council of the USSR on March 3, 1988 'on the criminal responsibil ty for illegal activity with radioactive materials'" (Nikiforov et al. 1989).

Another new entity is the USSR Academy of Sciences' Institute of Deveiopment of Atomic Energetics (ISDAE) in Moscow. ISDAE was created to provide techn:cal assistance to the newly established regulatory organization in the Soviet Union (Nuclear News 11/89). 


\subsection{KEY WASTE MANAGEMENT RESEARCH AND DEVELOPMENT INSTITUTIONS}

\subsubsection{High-Level Waste Management Facilities}

\section{Institute of Physical Chemistry}

The Institute of Physical Chemistry in Moscow is a branch of the USSR Academy of Sciences. The institute performs research and development on geologic waste disposal and waste form properties (Leigh 1989).

Al1-Union Scientific Research Institute for Inorganic Materials

The Al1-Union Scientific Research Institute for Inorganic Materials in Moscow carries out R\&D on high-level waste vitrification and properties of solid waste forms (Leigh 1989; Polyakov et al. 1989).

\section{Chemical Plant Research Institute}

The Chemical Plant Research Institute, located at Sverdlovsk, carries out R\&D on high-level radioactive waste solidification. It has operated a twostage vitrification pilot plant, using a fluidized-bed calciner and a melter, that produced $20 \mathrm{~kg} / \mathrm{h}$ of phosphate glass in batches of $160-180 \mathrm{~kg}$ (Leigh 1989).

\subsubsection{Low- and Intermediate-Level Waste Management Facilities}

Basic research in low- and intermediate-level waste management as of 1970 was being conducted by the following facilities:

- Institute of Atomic Energy (I.V. Kurchatov) and its Moscow decontamination station, Moskovskaya Stantsiya Ochistki (MSO)

- Institute of Physical Chemistry USSR Academy of Sciences (IFKhAN)

- Central Radiation Safety Station (TsSRB)

- Scientific-Research Institute of Atomic Reactors (NIIAR) (Spitsyn et a1. 1970a). 


\subsection{INTERNATIONAL EXCHANGES AND AGREEMENTS ON WASTE MANAGEMENT}

The USSR carries out significant technical exchanges, mostly with Eastern bloc countries but some with Western countries, on nuclear power and related activities. Waste management related information is summarized in this section, with additional information on other nuclear fuel cycle exchanges and agreements given in Appendix $A$.

\subsection{SUMMARY}

The USSR provides nuclear fuel cycle services, including fuel reprocessing and management of reprocessing wastes, for the Council for Mutual Economic Assistance (CMEA) countries(a) and other purchasers of Soviet nuclear power stations. The USSR has also provided uranium conversion and enrichment services to a number of countries since 1973 (Semenov 1989). The primary technical focus of USSR bilateral relations is in the fields of reactor engineering safety and regulation, decommissioning and, more recently, waste management. There have been no bilateral agreements between the USSR and the United States in the field of radioactive waste management, although, at the recent IAEA International Waste Management Advisory Committee (INWAC) meeting, the Soviet delegate expressed interest in opening discussions (Cooley 1989).

\subsection{COOPERATION WITH OTHER COUNIRIES}

\section{Canada}

A two-year agreement was recently signed in which Canada and the USSR will exchange information on nuclear developments. This resumes a practice which was halted after the Soviet invasion of Afghanistan. In addition to reactor safety, the USSR is interested in waste disposal R\&D being carried out at the Canadians' Underground Research Laboratory (URL) (BBC 3/10/89). The agreement allows for toll enrichment of Canadian uranium in the USSR, with

(a) Member countries: Bulgaria, Cuba, Czechoslovakia, German Democratic Republic, Hungary, Mongolia, Poland, Rumania, USSR, Yugoslavia and Vietnam. 
both the enriched stream and the depleted tails returned to Canada or to a country acceptable to Canada.

A new expanded agreement was signed on November 20, 1989, between Canada and the USSR which calls for "full-scale cooperation for peaceful applications including 'the supply of nuclear material,' industrial cooperation, technical training, exchange of experts and specialists, and 'the exploration for and development of uranium resources'" (Nuclear Fuel 12/89, p. 5).

\section{European Community}

The European Community (EC) and the Soviet Union signed an unprecedented commercial and economic accord on December 18, 1989, that allows for cooperation in a wide range of activities including nuclear power development, safety, and research. Among other things, the document calls for exchange of personnel and nuclear research expertise. Nuclear cooperation with the Soviet Union will be administered under the European A:omic Community (Euratom) Treaty, basically a framework for voluntary cooperation among the 12 member states of the EC (Nucleonics Week 12/89).

\section{France}

An agreement on decommissioning was signed on June 28,1988 , between France's Framatome and Minatomenergo. The agreement covers engineering, equipment design, and preparatory work for facility dismantling (Nuclear News 8/88). A new agreement was signed in January 1989 with an expanded scope beyond decommissioning (EIA I989a).

\section{Federal Republic of Germany}

The West German firm, KWU, has had a bilateral agreement with the Soviet Union for over a decade. Technical exchange seminars have been proposed on a wide variety of issues such as reactor safety, waste treatment technology and spent fuel transport.

Technabexport, the Soviet foreign trade marketing organization, concluded a basic contract worth about $\$ 4.4$ million with Nukem of West Germany in September 1988 for delivery of waste treatment facilities for low-level radioactive waste (ATW News $11 / 88$ ). 
The Soviets have offered to provide LWR fuel assemblies to the FRG and to take track the spent fuel assemblies for final disposition in the USSR (DOS 1988).

In June 1989, officials from HTR GmbH and the USSR State Committee for the Utilization of Atomic Energy. (GKAE) signed a memorandum in Frankfurt which agreec to "basic principles" of negotiation for the project to build an 80 -MWe (200-MWth) high-temperature gas-cooled reactor in Dimitrovgrad by 1996 . An HTR press statement said the memorandum marked an "important intermediate step" in project negotiations, because certain "preconditions are now establishec" for cooperation between the USSR and Germany at Dimitrovgrad. Most important of these, officials said, was German consent to be paid in countertrade--most likely, sources said, in the form of enriched uranium or enrichment services (Nucleonics Week 7/89a).

\section{Hungary}

The USSR has an agreement with Hungary to receive Hungarian uranium ore or ore products and return new spent fuel elements for Hungarian reactors. It was stated that if the Hungarians go elsewhere for fabrication of their nuclear fuel, the USSR would not take the Hungarian spent fuel for disposal. (B8C 2/23/89). On November 16, 1989, the Hungarian Counci1 of Ministers, presumably over economic difficulties, suspended their agreement with the USSR to design and build the Paks $5 \& 6$ WVER-1000 reactors (EIA 1989a).

\section{Nigeria}

The USSR has been using equipment that contains radioactive isotopes at Ajaokuta in Nigeria. The Nigerians claim that the Soviets plan to store radioactive wastes at the Soviet construction site at Ajaokuta. This claim is denied by the Soviets (BBC 9/1/88).

\section{United Kingdom}

The UK Nuclear Installations Inspectorate (NII) and GAEN agreed in March 1988 to conduct exchanges of information on nuclear safety and regulation, including siting, construction, commissioning, operation and decommissioning (NEI 5/88). 


\section{IAEA}

A Soviet proposal to set up an internationai research center at Chernobyl to study the effects of nuclear plant accidents and nuclear accident management has been discussed with the IAEA, according to Alexander Protsenko, the USSR's chief nuclear official and Governor to the IAEA board. IAEA Director General Hans Blix said that no firm plan for work on such a center had emerged from the high-level meeting held during the IAEA general conference in September 1989, and that the outcome of the Soviet proposal was "very unclear." The proposal for the center was first put forward at the June 1989 meeting of the IAEA Board of Governors. Officials from other countries, including the U.S. and France, said they were not rejecting the proposal out of hand but that they had major questions about the wisdom of creating a Chernobyl center, both for its potential financial implications and because it might duplicate existing efforts.

Another proposal was made in June 1989 for an international research center on high-level nuclear waste disposal. Protsenko sajd that depending on how the center is organized, "we might consider the possibility of having it in our country." The Soviet Union has not formally proposed to host such a center, but is prepared to consider setting up one that would accept foreign waste for treatment (Nucleonics Week 10/89a).

\subsection{COOPERATION WITH THE UNITED STATES}

A Memorandum of Cooperation between the U.S. and the Soviet Union on the utilization of atomic energy for peaceful purposes was signed in Washington, D.C., on November 24, 1959 (Seaborg et a7. 1963) and is still in effect today,

The U.S. NRC and the GKAE signed a Memorandum of Cooperation in ApriT 1988 concerning nuclear safety and its regulation, training, health effects, environmental protection and safety research. The memorandum, an addendum to the 1959 overall cooperative agreement, is in effect for five years and can be extended. It creates a joint coordinating committee for civilian nuclear reactor safety, to consist of six representatives each from the NRC and GKAE. The committee may organize, establish and arrange working groups, conferences and seminars of specialists for joint discussion and study of specific topics. 
It may also review and comment on reports coming out of such working groups and conferences. The agreement calls for exchanges of scientific and technical safety information, personne?, and equipment (Nucleonics Week 4/88).

An agreement has been signed between the Kurchatov Institute and the American Nuclear Society to exchange information on public relations aspects of nuclear power (NEI 4/89). A USSR Nuclear Society, one of whose principal aims is the fostering of international collaboration, became a full member of the European Nuclear Society at an ENS meeting in Karlsruhe on July 7, 1989. The new society's president, Academician E. P. Velikhov, marked the occasion by calling for the setting up, under the IAEA, of an international project to develop safe reactors for the twenty-first century. Other aims of the Soviet Nuclear Society are improved public information and the ending of secrecy in the civil sector. Vice presidents of the new society are N. PonomarievStepnoi and V. Orlov, and its Executive Secretary is A. Gagarinski of the Kurchatov Institute (NEI 10/89, p. 10).

When asked during an April 1989 IAEA meeting if the Soviets are interested in further discussions and technical exchanges with the U.S. on the vitrification of high-level waste, Mr. Nikiforov (from the All Union Research \& Scientific Institute of Inorganic Materials in Moscow) replied that they are ready and are already conducting exchanges with France and the Federal Republic of Germany (Cooley 1989). Progress has been made such that the U.S, and the Soviet Union are laying the groundwork for a bilateral agreement on research in radioactive and mixed radioactive/hazardous waste management. U.S. Energy Secretary James Watkins and Leo Duffy, the DOE special assistant for defense nuclear waste management, met with Soviet officials in Vienna in the fall of 1989. One source said the USSR is particularly concerned with transuranic waste management, which some Soviet officials have said should be handled as an international problem (Nuclear Waste News 9/89).

On January 9-12, 1990, the U.S. Environmental Protection Agency (EPA) reviewed an 18-year-oid agreement with the USSR on environmental cooperation and research, including the first joint study of environmental effects of radioactive contamination, as part of seven new projects. One project will 
examine the impact of radioactivity on marine 'ife in the northern $B$ lack Sea, which receives most of the runoff from the Chemobyl region (Report on Defense Plant Wastes $1 / 90)$. 


\subsection{WASTE MANAGEMENT IN THE FRONT END OF THE NUCLEAR FUEL CYCLE}

Summary information on the front end of the fuel cycle in the liSSR, presented in this section, is confined to mining and milling of uranium ores. Waste management information from uranium fuel naterial purification and conversion to uranium hexafluoride, enrichment of the fissile content of the uranium, and fabrication of fuels for nuclear reactors is not available.

\subsection{SUMMARY}

The USSR provides uranium processing and conversion and fuel fabrication services and takes back all spent fuel from Soviet-supplied reactors to other countries. Relatively little is known about Soviet waste management activities in uranium mining and milling and essentially nothing is known about their waste management activities in the rest of the front end of the fuel cycle. Uranium mining waste management practice is primarily by ground cover and backfilling mined areas with power plant ashes, rock and "tailings from enrichment and hydrometallurgy" processes. Mining operations appear to be causing increasing public concern in the Soviet Union.

\subsection{FOLICY AND STRATEGY}

Since 1973, the USSR has been offering, to firms in western countries, services in the processing of uranium concentrate from mining and milling, and conversion to uranium hexafluoride to enrichment. The materials are processed in the USSR and returned to the country of origin as enriched uranium hexafluoride or nuclear fuels. The ports of Leningrad and Riga have been used for these shipments (Semenov 1989).

The USSR obtains most [probably around 60\%] of its uranium from other countries, with its main suppliers being Czechoslovakia and the German Democratic Republic (Economist 5/10/86).

little has been stated on the USSR waste management policy. Nikiforov, in 1989, noted the safe management of liquid wastes "envisages circulating water supply" and "maximum employment of the main and auxiliary processes." 
Tailings were "a more serious problem," and the trend was toward backfilling of mined areas with tails, rocks, and fossil plant ashes (Nikiforov et al. 1989).

\subsection{WASTE MANAGEMENT ACTIVITIES}

According to a West Berlin television magazine program, the inhabitants of East German uranium mining areas are increasingly worried about the damage to the population's health there. Pictures of the uranium plants around Gera and Aue (in the southern part of East Germany) of the German-Soviet company Wismut AG were shown. Numerous "slag heaps" [assumed to be mi11 tailings] and contaminated plant facilities were claimed to be present from the decades of uranium mining. Numerous claims of radiation-caused health problems, birth malformations, and still-births have been made. The radioactive water effluents from the Wismut facilities have been fed into the Zwickau Mulde and White Elster rivers. The water table is contaminated from earlier washing of ore and seepage from uranium ore slag heaps. Dumping onto these slag heaps, which are up to $50 \mathrm{~m}$ high, has continued as of 1987, at which time 10,000 workers were believed to be working in mining operations. The dust from these slag heaps is reportedly settling on plants, gardens, residential areas, and schools (BBC 11/12/87).

A commission investigating why many children lost their hair in the town of Sillamae, Estonia, identified uranium waste stored at a factory as the most likely cause of poisoning. The Hinistry of Health measured radiation levels in the vicinity of the plant at three or four times normal background readings. The local press is now calling for removal of topsoil around the plant. The health ministry has allocated $\$ 96$ million for remedial action (Nuclear Waste News 7/89b). In 1990, Estonia asked for Finland's aid in measuring radiation from wastes stored in bituminous shale near Sillamae. The site has been used for more than 40 years to dispose of uranium-bearing wastes from processing imported ores. It was stated that several million metric tons of waste were located at the site (Nuclear Waste News $3 / 90$ ).

Leaching of pre-mined uranium ore in milling facilities is commonly done with solutions of sulfuric acid containing oxidants (such as pyrolusite, 
sodium or potassium chiorates, and ferric ions), particularly for silicateand aluminosilicate-based ores. Autoclave leaching at temperatures as high as $180^{\circ} \circ$ and pressures as high as 16 atmospheres is apparently used successfully and fairly commonly to extract uranium from lean, stubborn, and complex ores. Acid autoclave leaching has resulted in improvements in recovery of valuable components and reduced energy consumption, and has made it easier to create a closed ore processing system and avoid liquid and gaseous pollutants (Laskorin 1982).

Quantities of mine water, "excess water of hydrometallurgical plants [conversion plants], washing water, special laundry and laboratory water" range from $0.5-5.0 \mathrm{~m}^{3} /$ MT of mined and milled uranium ore, having "variations in uranium and radium content from $0.3-10 \mathrm{mg} / \mathrm{dm}^{3}$ and to $37 \mathrm{~Bq} / \mathrm{dm}^{3}\left(10^{-9} \mathrm{Ci} / \mathrm{l}\right)$ " (Nikiforov et al. 1989).

Uranium mining soils are treated by covering them with an overburden to prevent wind dispersion and water leaching. Ground cover is planted as well. Water from the mill tailings is treated and reused. Ashes from coal-fired power plants are also placed in some of the mined trenches (Cooley 1989). This practice was also recently amplified by Nikiforov, who added that an important trend was the "introduction of low-waste underground ore mining" with the mined area being backfilled with "dead rocks, taitings from 'enrichment [presumed to be from purification of ore materials] and hydrometallurgy, and thermoelectric plant ashes" (Nikiforov et al. 1989). 



\subsection{NUCLEAR REACTOR OPERATIONS WASTE MANAGEMENT}

The management of reactor operating wastes in the USSR is discussed only briefly in this section. Additional information on low-level and intermediate-level reactor-produced wastes is given in Section 9.

\subsection{SUMMARY}

Nuclear reactor operations in the USSR generate a variety of waste streams. General plant operating and low-level wastes now appear to be processed into solids, treated or discharged into drain fields or in some cases, the ocean. Low-level waste concentrates may be incorporated into bitumen (primarily) or concrete and stored at the reactor site. Historically, wastes from reactor operations were also disposed of by well injection. The possibility of vitrification of reactor operation waste is being considered. Longlived radioactive gases such as krypton, tritium and carbon appear to be vented to the atmosphere, while jodine and "aerosols" are removed, and the concentrates may possibly be incorporated into bitumen.

\subsection{POLICY AND STRATEGY}

The first nuclear power projects were started in the Soviet Union before the end of the 1940s. In 1950, the decision was made to construct the country's first nuclear power plant at 0bninsk, based on the so-called channeltype, uranium-graphite reactor design. The world's first nuclear power plant was commissioned on June 27, 1954, at 0bninsk. In the second half of the $1960 \mathrm{~s}$, it was decided to base further development of nuclear power on two therinal reactor types: the RBMK, a boiling water, graphite-moderated reactor, and the VVER, a PWR (Semenov 1983). As the basic reactor type for nuclear power development in the CMEA countries, the VVER-440 standard reactor was selected for the first stage of development, and the VVER-1000 for the second (Semenov 1983).

The basic safety document is GAEN's, "Nuclear Safety Regulations for Nuclear Power Plants," which was introduced in 1975. It regulates nuclear safe:y, governing not only criticality problems [operational safety] in 
reactor operation, but also refueling, transportation and storage of fuel assemblies. It contains the main technical and organizational requirements to ensure nuclear safety in the design, construction and operation of nuclear power plants, and the training requirements for personnel associated with reactor operation (Semenov 1983).

As of 1978 in the USSR, the general strategy for managing low- and intermediate-levei liquid wastes at reactors was a) where there were favorable geological and hydrogeological conditions at the nuclear power station, the wastes were neutralized to a neutral or alkaline $\mathrm{pH}$ and injected into deep, slow-moving aquifers that were bounded by aquitards; or b) where there were not favorable geologic conditions, liquid wastes were to be treated and converted to a solid for eventual disposal at a regional disposal facility (GKAE 1978, p. 8). Nikiforov adds that first-generation power plants store evaporator concentrates in concrete reservoirs lined with stainless steel, having a capacity of from $400-5000 \mathrm{~m}^{3}$. According to regulations, bottoms and sorbents are stored in different tanks (Nikiforov et al. 1989).

Today, at all nuclear power plants in operation in the Soviet Union, and for those under construction, facilities are being established to solidify reactor operations waste by evaporation followec by bituminization. A great deal of effort appears to have been spent in studying the fire and explosion potential of bitumen [due to the presence of nitrate salts], and fire-fighting systems have been installed (Nikiforov et al. 1589).

\subsection{REACTOR WASTE MANAGEMENT}

\section{3 .1 Systems and Activities}

In 1970, the Beloyarsk nuclear power plant treated sewage, wash water and other wastes using coagulation, distillation with vapor scrubbing and drying of the final solids (Kondratyev et al. 1970).

In 1977, in conformance with regulations of the State Sanitary Inspectorate regarding the protection of cooling ponds at nuclear power stations from radioactive contamination, low activity in effluents was removed in a variety of ways. At the Novo-Voronezh stations, for instance, the effluent 
was poured onto specially equipped plots of filter fields in a sanitary and protected zone. Discharging it into the River Don was not allowed. At the Beloyarsk station the effluent underwent additional "biological" treatment where some natural sorbents (siit) were used. After this treatment and subsequent radiation monitoring, the effluent was discharged into a marsh. In the River Don, at the Beloyarsk water storage basin and in the Koporsk Inlet of the Guif of Finland, the radioactivity levels were reportediy quite satisfactory, and bathing on and fishing from the beaches was permitted. At the Leningrad station the low-activity effluent was discharged, after about 100-fold dilution with inactive industrial and storm sewage, off the shore of the Gulf of Finland. The radioactivity limit (less than $10^{-10} \mathrm{Ci} / 1$ ) was maintained directly at the place of water discharge into the Gulf and not after it became mixed with the water of the Gulf (Gusev et a1. 1977).

As of 1981, homogeneous liquid radioactive wastes at nuclear power plants were collected in a receiver tank for mixing and neutralization. After removal of the coarse suspended materials and neutralization to a $\mathrm{pH}$ of about 11 , the mixtures were evaporated in one to three parallel evaporators until the sillts reached saturation at a concentration of about $300 \mathrm{~g} / 1$. The evaporators. were comprised of two stages and were typically of the natural circulation thermosyphon type. The concentrate was stored in a facility which consisted of concrete tanks lined with stainless steel. 0 il was removed from the evaporated vapors by charcoal filters, and radionuclides and salts were removed by ion exchange. Heterogeneous liquid wastes were routed directly to the storage tanks. Disposat of conditioned (originally liquid) low-level waste was expected to be carried out at each power station. This concept requires minimization of volume and production of a high-durability final waste form (Nikiforov et al. 1981b).

A central treatment facility is used to bituminize LLW concentrates at some milti-reactor power stations (Sapovnikov 1988). To save storage space at RBMK power stations, the bituminized waste is poured into "pits" at the onsite "repository," and is not placed in conventional storage facilities. However, this is not considered to be the final disposal solution (Nikiforov et al. 1981a). 
In 1981, the short-lived noble gases in a WVR reactor system were routed to a gas circulation ioop, in which small concentrations of hydrogen were burned on a platinum catalyst. From there the gases entered into one of three parallel decontamination systems. For pre-treatment of the radioactive noble: gases from reactor facilities, a sodium zeolite was used as a drying adsorbent before the chromatographic removal of the gases. The fraction of krypton- 85 released during WVR reactor operation as reported in 1981 supposediy did not exceed $1 \%$ of that generated, and therefore, it did not have to be removed before the gases were vented to the atmosphere. Similarly, tritium and carbon-14 were not removed because their contribution to doses is smail. Radioiodine and radioactive aerosols are removed. Radioiodine is removed by adsorbers of metallic iodides or silver-impregnated packings (Nikiforov et al. $1981 b)$.

For removing radioactive iodine and noble gases from reactor plant offgases as of 1981, extensive use was made of a chromatographic adsorption system, apparently using activated carbon and/or NaA-type zeolites. Aerosol filters ("absolute" synthetic fiber filters for dry aerosols and self-cleaning glass fiber filters for wet aerosols) were used for removal of particulates. As of 1981, the removal of liquid aerosols from reactor gases was done with "FARTOS" filters from which the removed liquids drain off continuously. Removal of solid aerosols was accomplished with filters having synthetic fibers as the first stage. When a second stage is used, glass-fiber filters ("absolute filters") were used (Nikiforov et al. 1981a). In 1989, it was stated that to trap radionuclides released from a nuclear reactor coolant, as wel1 as to eliminate free hydrogen generated by water radiolysis, a radiochromatographic gas cleanup system "is designed" that incorporates systems of hydrogen after burning, moisture removal, aerosol filtration, adsorption of numerous species of krypton, xenon and iodine. The resulting resins, slurries, and concentrates may be incorporated in bitumen (Nikiforov et a1. 1989).

The first facility for liquid radioactive waste bituminization went into operation in 1986 at the Leningrad RBMK-1000 power plant. The facility operates continuously when solidifying salt concentrates and batch-wise when solidifying slurries of ion-exchange resins and filter pearlite. Under 
continuous operation conditions the facility throughput is $500 \mathrm{l} / \mathrm{h}$. More than $6000 \mathrm{~m}^{3}$ of evaporator concentrates having an activity of $3.7 \times 10^{6}-10^{7} \mathrm{~Bq} / 1$ $\left(10^{-4}-10^{-5} \mathrm{Ci} / 1\right)$ and a salt content of 200-300 $\mathrm{g} / 1$ have been processed. About $3000 \mathrm{~m}^{3}$ of bitumen compounds filled with waste to $40 \%$ by mass, having a "water resistance of $10^{-4} \mathrm{~g} / \mathrm{cm}^{2}$ day, "have been disposed of in a repository of a "pour type." A similar bituminization facility is being introduced at the Ignalina power plant (Nikiforov et al. 1989). An installation for incorporating liquid radioactive wastes in cement is also being built at the NovoVoronezh power plant (Nikipelov et al. 1990).

The Institute of Inorganic Materials is running a major USSR campaign to reduce liquid LLW volumes (Nucleonics Week $5 / 88$ ).

\subsubsection{Waste Quantities}

A WVER-1000 currently produces between 10,000 and $15,000 \mathrm{~m}^{3}$ of liquid radioactive waste each year. The evaporation of the waste results in about 50 MT of saits. The RBMK reactor plants produce about $10,000 \mathrm{~m}^{3}$ of 1 iquid waste each year, resulting in about 100 MT of evaporated salts. The new RBMK being developed will produce about 50\% more waste than the units now in service because of increased complexity of piping (Nucleonics Week 5/88).

The projected amount of wastes from WVER and RBMK reactors can be roughiy calculated based on the above numbers. Assuming a WVER- 440 produces $60 \%$ of the waste of a WVER-1000, and a median number of $12,500 \mathrm{~m}^{3}$ of 1iquid wastes are produced per reactor year for the WVER-1000, the amounts of wastes were estimated. For WVER and RBMK reactors through 1989 , about $3.4 \times 10^{6} \mathrm{~m}^{3}$ of liquid waste [presumably, primarily low-level waste] are estimated to have been generated which contain an estimated 13,700 MT of salts. Solid active wastes are generated at Soviet nuclear power plants at the rate of 200-400 $\mathrm{m}^{3} /$ GWE-yr and stored with "filling factors of 50-60\%" in "special concrete structures" at the plant sites (Nikiforov et al. 1989).

The activity of homogeneous liquid waste (solutions from ion-exchange resin regeneration, decontamination of equipment, pipelines, premises and special clothes, leaks from equipment and cooling circuit) is from $3.7 \times 10^{2}$ to $3.7 \times 10^{5} \mathrm{~Bq} / 1\left(10^{-8}-10^{-5} \mathrm{Ci} / 1\right)$. The activity of heterogeneous waste 
(fi)ter material slurries) is from $3.7 \times 10^{6}$ to $3.7 \times 10^{9} \mathrm{~Bq} / 1\left(10^{-4}\right.$ to $\left.10^{-1} \mathrm{Ci} / 1\right)$ Nikiforov et a7. 1989).

\subsubsection{Research and Development (See also Section 9)}

Problems with scaling in the stainless steel waste evaporator tubes (requiring acid clean-out about once a month) and plugged concentrate pipes have led to additional R\&D. Increasing circulation and not allowing boiling in the reboilers has helped significantly in el iminating evaporator tube scaling. Another concept involves evaporation under acidic conditions (acidified using nitric acid). This allows for increasing salt content to about $650 \mathrm{~g} / 1$ while reducing scaling and pipe plugging, but volatilizes some of the boric acid (which would then require recovery by fractional distillation) and oxidizes the oxalic acid (Nikiforov et al. 1981b).

Laundry water from nuclear power stations was combined with other homogeneous aqueous wastes in 1981. However, consideration was given to using reverse osmosis for processing this water (Nikiforov et al. 1981b).

In 1981, for final conditioning of Tiquid radioactive waste concentrates from nuclear power stations, dehydration of the waste in dryers to a slurry with 20-30\% moisture, followed by bituminization, was under development. Several drying and bituminizing concepts were studied (Nikiforov et a1. I 981 b).

The feasibility of vitrification of power plant waste is being considered. It is expected that this will increase the degree of radionuclide fixation by 2-4 orders [of magnitude] compared with bituminization and cementation, and will reduce the volume of waste to be disposed of by a factor of 2-3 compared with bituminization and by a factor of 4 compared with an improved cementation process (Nikiforov et al. 1.989).

\subsubsection{Cost Information}

The total capital and annual operating costs of bituminizing intermediate-level 1 iquid waste concentrates from power reactor stations followed by at-reactor storage was reportedly lower than for long-term storage of the concentrates in tanks. Capital costs of bituminization were slightly over half of those for in-tank storage (Nikjforov et al. 1981a). 


\subsubsection{Safety and Quality Assurance}

In determining standards for the discharge of radionuclides into cooling water basins, the Soviets as of 1977 employed the principle of allotting a small quota (not more than $5 \%$ of the radiation dose limit) for the exposure of individuals to a given source of radiation. In 1977, water in these basins could be put to a number of uses such as drinking and industrial water suppiy, the watering of cattle, irrigation, fishing, and bathing. At the Kola station, for example, an experimental breeding farm has been set up with the thernal water in the discharge canal being used to breed trout, bester and other valuable species of fish. So far, no accumulation of radionuclides in the tissues of even fast-growing fish that can be attributed to the effluent has been observed (Gusev et al. 1977). Nikiforov reports that power plant operation practice shows that "under normal conditions releases [of gases] into the atmosphere are well below the sanitary standards" (Nikiforov et al. $1989 ;$.

A special commission under the aegis of the USSR Academy of Sciences has conc" uded that underground siting of reactors could be the answer to future nuclear plant safety, according to the commission's chairman, $V$. Subbotin. The stimated $20 \%$ cost penalty for underground construction could be offset by an expected reduction in the cost of waste disposal following plant decommissioning. It was stated that underground reactors could just be left to "die" after decommissioning, with just some additional shielding. [This concept sounds like decommissioning by entombment.] Underground reactors would also eliminate the need for conventional containment, which is now considered necessary for all nuclear power reactors under construction (MacLachian 1989). 



\subsection{SPENT FUEL MANAGEMENT}

Information on activities and plans for spent fuel storage in the USSR is given in this section. This includes at-reactor storage, central storage, spent fuel conditioning and other related information. In addition, spent fuel management activities following the Chernobyl accident are summarized.

\subsection{SUMMARY}

Official Soviet policy calls for a closed fuel cycle. Spent fuel from WVER -440 reactors has historically been cooled for three years prior to reprocessing, which was changed to five years in 1981. Other fuel types have not been reprocessed in significant quantities. The Soviets say that their reprocessing efforts are behind schedule, however, and thus storage of 10 years or more may be required. Spent fuel is stored briefly in pools at the reactor, then moved to longer-term storage facilities at reactor sites. The USSR also accepts the spent fuel from Soviet-built reactors supplied to other countries for reprocessing. Storage in dry casks has also been studied, using a West Germar Castor $V$ cask.

\subsection{FOLICY AND STRATEGY}

The general Soviet policy for spent fuel management from nuclear power reactors is to cool the fuel for five years [three years until 1982] at reactors before reprocessing.

Up until 1982, Soviet WVER-440 fuel was reprocessed after a three-year cooling time. Shipments of spent fuel from CMEA European countries and Finland followed this three-year schedule. After 1982, the cooling time was increased to five years, and, as a result, the CMEA countries and Finland have had to build additional storage facilities for their spent fuel. In 1982, at the IAEA International Conference on Nuclear Power Experience in Vienna, the Soviets announced that a delay in the FBR development would slow reprocessing of civilian spent fuel, which would require building away-from-reactor (AFR) storage facilities. Cooling times would be extended from 3 to 5 years, with possible extensions to 10 years. Finland, which has contracted to return all 
spent fuel from its two WVER-440s to the USSR for reprocessing, was a? so notified that its cooling time would be increased from three to five years (Dubrovsky et a]. 1982).

Spent fuel from RBMK reactors is being stored indefinitely without reprocessing because it is not yet economical to reprocess it (Cooley 1989). However, reprocessing of power reactor fuels has not kept up with accumulating spent fuel, so much of this waste is stored at Independent Spent Fuel Storage Installations (ISFSIs) located at nuclear power plant sites. Because of delays in implementing fast reactors and delays in reprocessing, construction of additional ISFSIs, designed to store about 10 to 30 years of nuclear power plant production, are planned. This solution, rowever, does not remove the need to transport and reprocess spent fuel, but just slows down its implementation (Semenov 1983; Johnson 1986).

Dry cask storage of spent fuel has been evaluated. More recent reactor storage basins have nominal 30-year design lives, and the walls and bottoms of basins have double liners of mild steel and stainless steel.

\subsection{SPENT FUEL QUANTITIES AND CHARACTERISTICS}

By the start of the twenty-first century, about 30,000 MT of spent fuel will have been removed from nuclear power stations in the USSR. By that time, the USSR is expected to have reliable storage space for three times that quantity of spent fuel (BBC $2 / 17 / 89)$.

The first spent fuel from the Soviet-built reactors at Lovi isa, Finland, was sent to the USSR in about 1981. The second shipment of 120 fuel assemblies (about 14 MT) was made to the Soviet Union in four Soviet rail casks in August 1982 (BBC 8/26/82).

Table 6.1 shows the characteristics of spent fuel generated in USSR nuclear power reactors. Figure 6.1 shows the authors' estimate of spent fuel discharged from all WER (including those in CMEA countries) and RBMK reactors through 1989 based on Soviet nuclear fuel cycle information (Romanenko et a 1 . 1982). 
IABLE 6.1. Typical Characteristics of Spent Fuel from Soviet VVER, RBMK and Fast (BN) Reactors

\begin{tabular}{|c|c|c|c|c|c|c|}
\hline Reactor and Fuel Parameters & $\begin{array}{l}\text { Unit of } \\
\text { Measure }\end{array}$ & $\begin{array}{l}\text { VVER- } \\
440 \\
\end{array}$ & $\begin{array}{l}\text { VVER- } \\
1000 \\
\end{array}$ & $\begin{array}{l}\text { eactor T } \\
\text { RBMK- } \\
1000 \\
\end{array}$ & $\mathrm{BN}-350$ & BN-600 \\
\hline $\begin{array}{l}\text { Reactor Power } \\
\text { Electric }\end{array}$ & MW & 440 & 1000 & 1000 & 350 & 600 \\
\hline Thermal & MW & 1375 & 3000 & 3200 & 1000 & 1470 \\
\hline Fuel Mass (in uranium) & MT & 42 & 66 & 190 & 6.5 & 7.5 \\
\hline Fuel Enrichment & $\%$ & 3.5 & 4.4 & $\begin{array}{l}1.8- \\
2.4\end{array}$ & -- & -- \\
\hline Average Burnup & MWd/kg & $2 B .6$ & $27-40$ & $\begin{array}{l}15.5- \\
22.3\end{array}$ & 50 & 60 \\
\hline $\begin{array}{l}\text { Annual Fuel Unloading } \\
\text { (in uranium) }\end{array}$ & MT & 12.5 & 21.0 & 50 & 7.4 & 6.2 \\
\hline $\begin{array}{l}\text { Number of Fuel Assemblies } \\
\text { in Reactor }\end{array}$ & -- & 349 & 151 & 1661 & 200 & 370 \\
\hline $\begin{array}{l}\text { Uranium Mass per Fuel } \\
\text { Assembly }\end{array}$ & $\mathrm{kg}$ & 120 & 437 & 113 & 32.5 & 20.3 \\
\hline Fuel Assembly Length & $\mathrm{mm}$ & 3217 & 4570 & 10065 & 3500 & 3500 \\
\hline $\begin{array}{l}\text { Fuel Assembly Width } \\
\text { (across flats) }\end{array}$ & $\mathrm{mm}$ & 144 & 238 & 79 & -- & - \\
\hline Fuel Rod Diameter & $\mathrm{mm}$ & 9.1 & 9.1 & 13.6 & 6.1 & 6.9 \\
\hline Fuel Rod Cladding Thickness & $\mathrm{mm}$ & 0.65 & 0.67 & 0.90 & 0.35 & 0.4 \\
\hline $\begin{array}{l}\text { Number of Fuel Rods } \\
\text { per Assembly }\end{array}$ & -. & 126 & 317 & $18 \times 2$ & -- & -- \\
\hline $\begin{array}{l}\text { Fuel Specific Activity } \\
\text { After 3-Year Cooling }\end{array}$ & $M C i / M T$ & 0.65 & 0.78 & 0.50 & 1.45 & 3.06 \\
\hline $\begin{array}{l}\text { Energy Release After } \\
\text { 3-Year Cooling }\end{array}$ & $\mathrm{kW} / \mathrm{MT}$ & 3.0 & 3.6 & 2.5 & 4.0 & 7.0 \\
\hline
\end{tabular}

Ref.: VVER, RBMK reactors--Philippov et al. 1989; Dollezhal' ${ }^{\prime}$ et al. 1981; USNRC 1987. BN reactors --Kondratyev et al. 1986. 


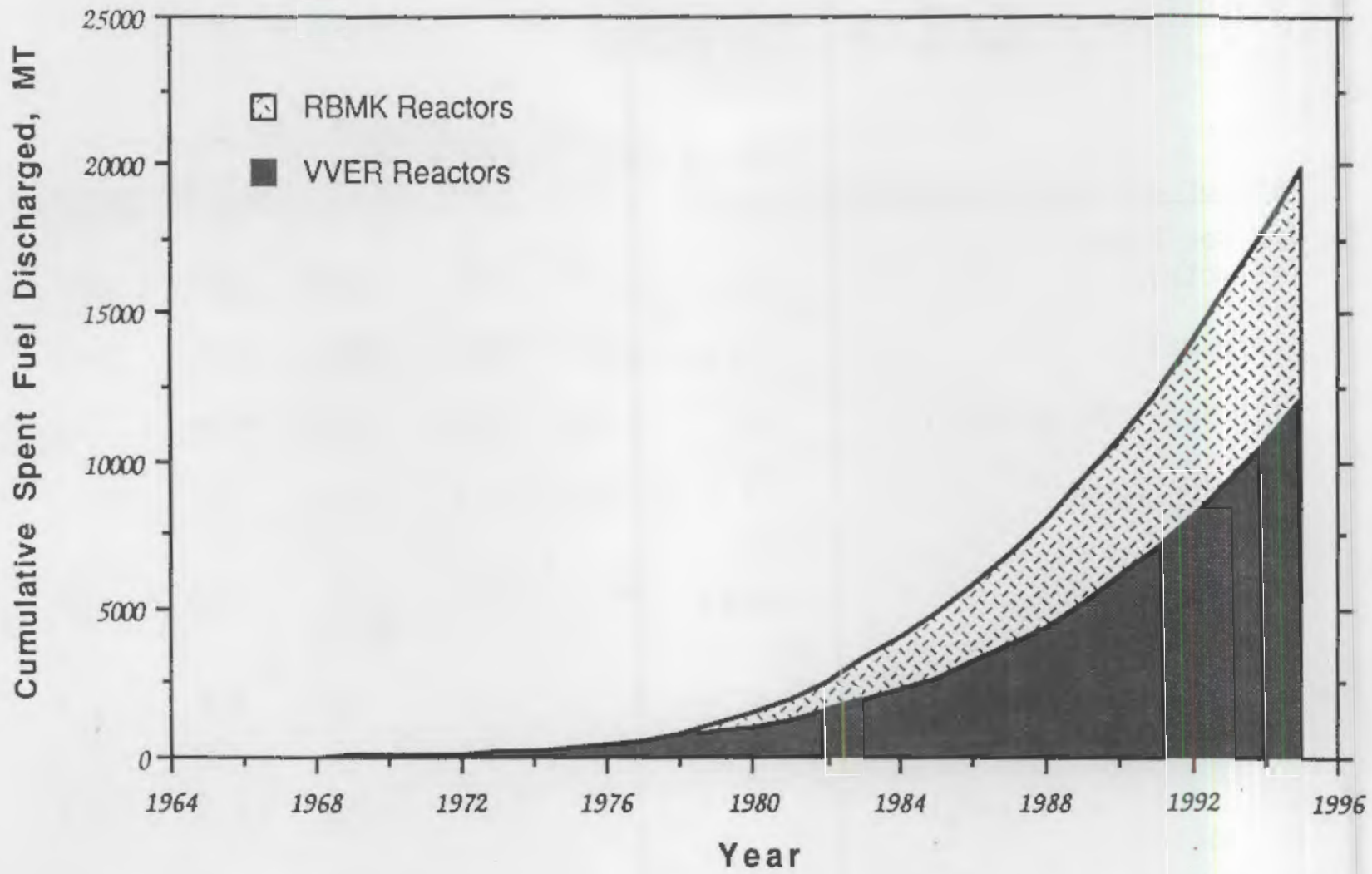

FIGURE 6.1. Estimated Spent Fuel Discharged from VVER and RBMK Reactors

\subsection{REACTOR SPENT FUEL STORAGE}

\subsubsection{VVER Reactors}

The standard storage capacity for spent fuel at VVER-440 reactors is for a total of 698 assemblies ( 84 MT). The assemblies are stored in the spent fuel storage pool in the reactor building, connected to the reactor vessel room via a transfer canal. The lower level of the storage pool can be filled with 349 assemblies. When this level is full, an additional 349 assemblies can be stored above the lower assemb1ies, for a total of 84 MT. At an average refueling rate of $14 \mathrm{MT} / \mathrm{yr}$, this capacity represents a six-year storage capacity with no full-core-reserve space and a three-year capacity with fullcore-reserve space (DOE 1987). Recent defueling of two Armenian VVER-440s required removal of existing spent fuel from the pool before the core could be discharged. [This indicates that storage space for a full core of spent fuel was not available and apparently is not required.] (Nucleonics Week 3/89). 
Based on these small at-reactor storage capacities, a standard, central wet storage facility was designed for use at multiple-reactor power stations (DOE 1987).

VVER reactor operation allows for a direct discharge of spent fuel into a coolirg pool, where cooling is maintained through natural convection. An important characteristic feature of the WVER-1000 reactor is the rather high specific heat loads in fuel pins of up to $490 \mathrm{~W} / \mathrm{cm}$. The release of fission gas products under the fuel cladding during the lifetime of reactor operations and fuel storage is $40-50 \%$. The design of the fuels is such that at the end of their cycle the pressures exerted by the coolant and the gas mixture under the fuel cladding are equal. Therefore, when fuel assemblies are placed in a s.torage pool, fuel cladding experiences tensile stresses up to 70-80 MPa, which, as is known, accelerates corrosion processes. Consideration has been given to the use of a bimetallic cladding for VVER-1000 fuels. The investigations show that a layer of pure zirconium $1 \mathrm{~mm}$ thick applied to the inner surface of a clad reduces by a factor of 5 or more the design crack depth at the end of a cycle. The maximum time of storage in a pool depends mainly on the fuel ciad condition following irradiation. (a)

After 10 years of storage at the Novovoronezh VVER nuclear power plant, $0.5 \%$ of fuel assemblies have developed fuel rod depressurization or "gas leakage" (Veretennikov et al. 1986).

The Izhorskiy Works in Leningrad has set up production facilities for storage racks for spent nuclear fuel. The new honeycomb racks can accommodate twice as many fuel assemblies as earlier models and use a new steel in their hexagonal casing tubes. The newly developed steel has also been used for spacers in spent fuel shipping casks (BBC 4/8/88).

As a result of investigations by the Hungarians on high-density spent fue 1 storage, the at-reactor racks at their Paks 1, 2, 3 and 4 WVER reactors were back-fitted. The overall requirements were that the k-effective of 0.95

(a) Bibilashvili, Yu. K., S. M. Bogatyr', A. V. Medvedev and V. V. Novikov. 1988 or 1989. "Some Aspects of WVER and BN Irradiated Fuel Strength During Storage and Shipping." A. A. Bochvar's All Union Scientific and Research Institute of Inorganic Materials, Moscow, U.S.S.R. 
with unborated water could not be exceeded, no credit was assumed for reactivity burnup, and maximum fuel enrichment was assumed. The racks were designed with a 4-mm water gap between the hexagonal shroud faces, which allowed for doubling of the storage capacity (Ferenc 1985).

\section{4 .2 RBMK Reactors}

Spent fuel is discharged from the RBMK reactor channels into cooling pools by the refueling machine without the reactor being shut down (Kondratyev et al. 1986).

RBMK spent fuel cooling pools at the reactor are open water-filled "reservoirs" $700 \mathrm{~m}^{3}$ in volume. The pools are lined with stainless steel on the inside, and the outer walls are lined with $3 \mathrm{~mm}$ sheet stee ?; the bottom is lined with $8-10 \mathrm{~mm}$ plate steel. Fuel assemblies are suspended from the beams (Philippor et a1. 1989). As the cooling pool is filled, the fully irradiated fuel assemblies are transported to the long-term storage pools and the partially irradiated assemb]ies may be reinserted in the reactor (Varovin et al. 1986).

The cooling pool water has a pH of 5.5-8.0 and an electrical conductivity of $3 \mu \mathrm{Sm} / \mathrm{cm}$ [believed to be the units of Siemens, thus equiva]ent to $3 \mu \mathrm{mho} / \mathrm{cm}$ ] (at $25^{\circ} \mathrm{C}$ ). The impurities content must not exceed 100 parts per billion (ppb) of chlorides, $1000 \mathrm{ppb}$ of iron and $20 \mathrm{ppb}$ of oil (Philippov et al. 1989).

The special building for central interim storage of RBMK fuel is located at the power plant site, and is designed to receive spent fuel from four reactors for 10 years with a capacity of $1800 \mathrm{MT}$ (storage density is $3 \mathrm{MT} / \mathrm{m}^{2}$ ) (Kondratyer et a1. 1986).

\subsubsection{Fast Reactors}

Water-filled pools are used also to store spent fuel from BN (i.e., fast) reactors. Spent fuel reloading, under "dry" conditions, is done during reactor shutdown simultaneously with routine maintenance. An inert gas atmosphere is used to allow reloading of the spent fuel assemblies with residual sodium coolant. The requirements for fuel rod washing make it necessary to subject the fuel assembly to interim holding in an in-reactor storage facility 
(ISF), (a) The fuel assembly residence time in an ISt is equal to the period between refueling. Spent fuel assemblies initially were transferred from the reactir core to the ISF for heat removal for about 150 days (Kondratyev et a1. 1986) Today, this period is equal to 180 days for the Soviet fast reactors. In the future it may be increased to 200-250 days. In an ISF, the fuel cladding iemperature and gas internal pressure-effected stress levels are essentiall the same as those under operating conditions. Today, the problems of the dynamic structural strength of spent fuel at moderate temperatures, particularly of those irradiated to high burn-up, require additional research. (a)

With the next reactor shutdown, BN spent fuel assemblies are reloaded from the in-reactor storage pool into sodium-filled drums for about 90 days additional cooling. Spent fuel assemblies are then transferred into a washing chamber, where fuel element cladding integrity is tested. The assemblies without defective elements are placed in water-filled cans and those with defective elements are placed in lead-filled cans. Spent fuel assembly canning and sealing are done in a special well connecting the washing chamber with water-filled spent fuel storage pools. The spent fuel assemblies that have been placed into sealed cans are transferred to the spent fuel reception bay $b$ : the elevator. In this bay the cans with fuel assemblies are placed into we baskets, 28 assemblies in each. The $\mathrm{BN}-350$ reactor operation experience has shown that storage of intact spent fuel assemblies without cans is possible. The cans with prewashed intact fuel assemblies are moved by the pool crane to their appropriate storage positions before shipment to a reprocessing site (Kondratyev et al. 1986).

Fast reactor fuels with ferritic and ferritic-martensitic steel cladding corrocte during storage in water. Therefore, storage in special containers in deion zed water or with inhibitors is being considered (Johnson 1989a).

(a) Bibilashvili, Yu. K., S. M. Bogatyr', A. V. Medvedev and V. V. Novikov. 1988 or 1989 . "Some Aspects of VVER and BN Irradiated Fuel Strength cluring Storage and Shipping." A. A. Bochvar's All Union Scientific and Research Institute of Inorganic Materials, Moscow, U.S.S.R. 


\subsubsection{CMEA Countries}

In Czechoslovakia (and other CMEA countries), nearly all nuclear power reactors are Soviet-built WWERs. Spent fuel from WWER-440 reactors is stored for three years in "at-reactor pools" that are situated in a reactor hall and filled with a solution of boric acid in water at a concentration of about $12 \mathrm{~g} / \mathrm{kg} \mathrm{H}_{2} \mathrm{O}$. For the next two years, the spent fuel is stored in an "awayfrom-reactor storage facility" [ISFSI] at the Jaslovske Bohunice site. About five years after the fuel is discharged from the reactor, it is transported to the Soviet Union. Spent fuel in the reactor pools is stored in multi-pocket casings. There are 30 intact fuel assemblies in one casing, and 56 casings can be stored in a pool (Petényi et al. 1988).

Main components of ISFSIs are:

- four storage pools, one is permanently considered an auxiliary unit

- equipment and rooms are used for acceptance and transport of spent fuel

- technological equipment is used for operation of ISFSIs, mainly a cooling system of the pool and a ventilation system above the coolant surface (Petényi et al. 1988).

\subsubsection{Operations and Other Information}

Spent fuel from WWER-440 and -1000 reactors is stored in hexagonal canning tubes made of $1 \%$ borated stee 1 , which makes it possible to increase capacity of the storage pads by a factor of two over the original pool design capacity. The calculated values for spacing of spent fuel are based upon a burnup of $40 \mathrm{MWd} / \mathrm{kg}$ for WWER-1000 spent fuel and $30 \mathrm{MWd} / \mathrm{kg}$ for WWER-440 spent fuel. WVER-440 spent fuel (as well as WVER-1000 spent fuel) is stored under atmospheric pressure. [It is a] so implied that credit may be taken for burnup in the reactor storage pools.] (Fedorov 1987). In-pool burn-up scanning techniques have also been developed (Voronkov et al. 1988).

Spent fuel that is three years old [the minimum time] is removed from reactor storage basins and transferred to the respective central storage pool using a TK-6 transport cask (Dubrovsky et a1. 1982).

In comparing "wet" loading of a cask with spent fuel versus "dry" loading 
using a transfer cask, the dry loading is considerably faster. This is primaril; because of the reduced time for decontaminating the cask after wet loading, which can take up to 24 hours (Dubrovsky et al. 1982). [However, it is no: known if dry loading is used.]

It was recently reported that spent fuel is stored in reactor pools for up to 10 years (Lehman 1989).

\subsubsection{Research and Development}

Higher density storage was investigated by the Hungarians and Soviets, and installed in Paks $1,2,3$ and 4 as a result of these investigations. Calculations and experiments were carried out at the Central Institute of Physics of the Hungarian Academy of Sciences in cooperation with the Kurchatov Institute in the USSR. The conclusion reached was that storage capacity of pools could be doubled, but that it would be expensive (DOE 1987; Dubrovsky et al. 1982; Ferenc 1985).

\subsection{INDEPENDENT SPENT FUEL STORAGE INSTALLATIONS}

\subsubsection{Facility Development and Locations}

in the early 1980s, additional storage of spent fuel beyond that in the reactor storage pool was to be provided by additional wet storage basins called Independent Spent Fuel Storage Instaliations (ISFSI) located at multiple reactor sites. The first of these under development was in 1981 at the four-reactor Kozloduy power station in Bulgaria. [However, as of 1980, at least one central AFR spent fuel storage facility was reported as being in operation for spent fuel (Nucleonics week 9/80).] The following central stations are currently known to be available (DOE 1987, except where noted):

- Loviisa 1 and 2 in Finland; capacity of 190 MT; service date 1985

- Paks 1, 2, 3 and 4 in Hungary; capacity of $600 \mathrm{MT}$; service date unknown

- Bohunice 1, 2, 3 and 4; Dukovany 1, 2, 3 and 4; and Mochovice 1, 2, 3 and 4 in Czechoslovakia; capacity of $600 \mathrm{MT}$; service date Fal1 .986 
- Novovoronezh 1,2, 3, 4 and 5 in USSR; capacity of 600 MT; service date unknown; operational in 1986 (Kondratyev et at. 1986)

- Kozloduy 1, 2, 3, 4 and 5 in Bulgaria; capacity of 600 MT; service date early 1980 s

- Nord 1, 2, 3 and 4 in GDR; capacity of 600 MT; service date unknown

- Leningrad 1, 2, 3 and 4; capacity of 1800 MT; service date unknown; operational in 1986 (Johnson 1989b; Kondratyev et a). 1986)

- Chernobyl 1, 2 and 3 in the USSR; capacity of 1800 MT; under construction in 1986 (Kondratyev et al. 1986)

- Kursk 1,2, 3 and 4 in USSR; capacity of 1800 MT; under construction in 1986 (Kondratyev et al. 1986).

\subsubsection{WVER Spent Fuel Storage}

The Kozluduy storage facility, said to be typical, is a separate facility. It is designed to hold 600 MT of spent fuel (or 5000 assemblies, the capacity for 10 years for the power station assuming $14 \mathrm{MT} / \mathrm{yr}$ discharge of fuel) from the WVER-440 reactors. This type of storage facility is planned to be used during the entire life of the nuclear power station (stated at about 30 years). The facility receives 30 spent fuel assemblies [or 18 non-integer assemblies] in one stainless steel basket in TK-6 casks, unloads the full basket under water, and places the basket full of spent fuel into its storage position. The pool walls and bottom are lined $w^{*}$ th individual layers of carbon steel and stainless steel (IAEA 1982; Pushkov 1984). The central spent fuel storage facility has four pools that are connected by water corridors. The water height above the active part of the spent fuel assemblies is three meters (Dubrovsky et a). 1982; Philippov et al. 1989).

The standard 600-MT centrai station for storage of WVER-440 spent fue? is $45 \mathrm{~m} \times 66 \mathrm{~m}$ in area, with a high-bay section about 24 meters long (of the 66 -meter length). The height of the majority of the building is 20 meters, and the height of the high-bay area is about 27-30 $\mathrm{m}$ (Dubrovsky et a1. 1982). Detailed descriptions of spent fuel storage facilities are available; the reader is referred to an article by Burmester et al. (1989). 


\subsubsection{RBMK Spent Fuel Storage}

RBMK spent fuel is suspended in the pool in water-filled, 60-1iter cans by metal rails above the pool while VVER spent fuel is stored in racks resting on the bottom of the pool (Johnson 1986; Philippov et al. 1989).

The radioactivity levei of deposits on RBMK fuel element surfaces can reach $10^{9}$ Bequerels [about 0.027 curies] per fuel assembly. Radionuclides are found on the surfaces of pools and storage equipment as well as on the surfaces of casks via:

1) release of fission products from beneath the fuel element claddings through defects

2) washing the radioactive deposits off the fuel element surfaces.

The radioactivity in at-reactor pools is usually at the level of $10^{3}$ to $10^{5} \mathrm{~Bq} / 1$ [or about 0.0027 to $0.000027 \mathrm{Ci} / \mathrm{m}^{3}$ ], while at independent spent fuel storage pools, the total activity of water is $1-2 \mathrm{~Bq} / \mathbf{1}$ (Philippov et al. 1989).

\subsubsection{Operations and Other Information}

The handling hall of the standard central spent fuel storage facility has cranes with load capacities of 125 and 20 MT for handling spent fuel transportation casks and their accessories. When the spent fuel is received from nuclear power plants for storage at the central storage facility, the transport cask is lifted vertically and lowered into the unloading basin. After unloading the spent fuel (in a single basket), the cask is removed from the basin, decontaminated, and fitted with a new basket for the next spent fuel load (Dubrovsky et al. 1982).

Spent fuel storage pool operation experience shows that large-scale decontamination of a pool is needed no more than once a decade. Such decontamination is connected, as a rule, with repair or reconstruction of the pool. Steam ejection and foam decontamination methods with the use of surfaceactive solutions have been used successfully. The main problem in decontamination of the pool is removal of radioactive sludge from the bottom. 
At present, special robotized devices are being developed for these purposes (Philippov et al. 1989). Spent fuel may be stored in ISFSI for periods of 25 to 50 years (Lehman 1989).

Spent fuel from Soviet submarines is reportedly stored in concrete bunkers at the nuclear submarine base at Paldiski, about $15 \mathrm{~km}$ south of Tallinn, Estonia (Nuclear Waste News 9/85). Naval reactor fuels were reported in 1989 to be reprocessed at Kyshtym (NRDC 1989).

\subsubsection{Research and Development}

As of 1986, the Soviets were carrying out a test of dry storage of spent fuel in a Castor $V$ storage cask purchased from the Federal Republic of Germany in 1984. Maximum fuel cladding temperature in the two-year test is $300^{\circ} \mathrm{C}$. The cask was loaded with spent fuel in 1984 (Johnson 1986). The cask was designed and has been undergoing testing for storing 12 WVER-1000 spent fuel assemblies (ATW NewS 8/84; Johnson 1986). A GNS $\vee$ transportation and storage cask was purchased in 1989 from the Federal Republic of Germany, indicating continued Soviet interest in spent fuel storage casks. (a)

\subsection{MANAGEMENT OF THE NUCLEAR REACTOR ACCIDENT AT CHERNOBYL ${ }^{(b)}$ \\ 6.6.1 Summary}

The Chernobyl Unit 4 Nuclear Power Plant (NPP), an RBMK-1000 reactor, suffered a very severe accident with disruption of the core and the reactor building on Apri1 26, 1986. It was the source of extensive radioactive contamination of the plant site, the environs and remote areas. In a short time the damaged unit was encased and isolated from the surroundings. The graphite fire and powerful local heat releases were quenched and the core debris condition stabilized.

The explosions and core destruction completely changed the fuel geometry in the reactor. Management of the damaged fuel involved such operations as picking up fragments of fuel and other radioactive materials dispersed at the

(a) Private communication with $H$. Baatz of GNS by K. J. Schneider, at PATRAM conference, June 1989, Washington, DC.

(b) Taken from Ryba7chenko 1988, except where noted otherwise. 
plant site, decontamination of installations and areas, transfer of the fuel debris to the storage facilities and entombment of the damaged unit. According to Nikipelov (1989), $50 \mathrm{MCi}$ were released while a value of about $81 \mathrm{MCi}$ $( \pm 50 \%)$ was reported by Nuclear. News $(10 / 86)$, which resulted in an evacuation of 135,000 people. The accident heightened Soviet and Western public distrust of nuclear power and launched a much more active anti-nuclear front in the USSR. AS a result of the Chernobyl accident, the Soviets introduced programs on adding safety features to RBMK reactors (primarily more fixed absorber rods, increased fuel enrichment to reduce the positive void coefficient, quicker insertion times, and modifications to the partial containment system). Training and safety requirements were increased and broad monitoring activities were established.

\subsubsection{RBMK Fue] and Core Characteristics}

The RBMK-1000 reactor, with an operating power of 1000 MWe or 3200 MWth, is a heterogeneous thermal reactor of a channel type [the fuel is located in a tube or "channel" that is isolated from the graphite moderator. The fuel channels are interspersed in a regular pattern throughout the graphite block], using $\mathrm{JO}_{2}$ fuel of $1.8-2.4 \%$ enrichment. The reactor is cooled by boiling water; the moderator is graphite. The design data on the RBMK-1000 reactor are given in Table 6.2 .

The fuel, in the form of $\mathrm{UO}_{2}$ pellets, is clad with a zirconium-niobium alloy. The fuel pins are $3.5 \mathrm{~m}$ long; the fuel cassette is $7 \mathrm{~m}$ long. The RBMK fuel cassette is comprised of two fuel assemblies (with a cylindrical cluster of 18 pins), of which one fits on top of the other.

Fuel loading is done while the reactor is operating with a special fueling machine; from one to two channels can be reloaded daily. The fresh fuel assemblies are transported to the reactor unit by a special railway car and are suspended in the main hall before loading.

Spent RBMK fuel is unioaded from the reactor into the at-reactor pool, located in the main hall. After a three-year cooling period it is shipped from the unit in special transport casks. 
TABLE 6.2. Typica] RBMK-1000 Design Data

Reactor Power: electrical (MW)

thermal (MW)

$3200(a)$

Coolant temperature: inlet $\left({ }^{\circ} \mathrm{C}\right)$

270

outlet $\left({ }^{\circ} \mathrm{C}\right)$

284

Coolant flow rate $\left(\mathrm{m}^{3} / \mathrm{h}\right)$

Average mass vapor content, at fuel channel outlet (\%)

37600 (a)

Steam output (MT/h)

Steam pressure in separators (MPa)

14.5

5800
6.8

Core dimensions: height (m)

equivalent diameter (m)
volume $\left(\mathrm{m}^{3}\right)$

7.0

$765^{11}(a)$

Number of operating channels

Number of reactivity control and protection system channels

Number of fuel assemblies per channel

Number of fuel pins in assembly

Fuel cladding diameter (thickness), mm

$13.6(09)$

Fuel cladding material

$\mathrm{Zr}+1 \% \mathrm{Nb}$

Maximum operating channel output (kW)

3000

Total heat flux surface area $\left(\mathrm{m}^{2}\right)$

9070

Mass of uranium (MT)

Average fuel enrichment (\%)

$2.0^{(a)}$

Average fuel burnup (MWd/MT)

Fuel operating life (d)

Mass of graphite (MT)

1080

Maximum graphite temperature $\left({ }^{\circ} \mathrm{C}\right)$

550

(a) Reference: USNRC 1987.

\subsubsection{Character of Reactor Core Disruption}

Before the Chernobyl accident, the core of Unit 4 contained 1659 [prior to equilibrium operation when there was 1661] fuel cassettes with the average burnup of $10.3 \mathrm{MWd} / \mathrm{kg}, 75 \%$ of the fuel from the first load having burnups of $12-15 \mathrm{MWd} / \mathrm{kg}$.

As it is known, the major factor contributing to the accident was a severe violation of operating rules by personnel [as well as critical design 
flaws], which put the reactor operation in an unsafe regime. Two explosions occurred, which led to the destruction of the core and the reactor building. Fires began and pieces of the core structures and metal construction, some hot graphite and fuel were ejected from the reactor vault into the nearby compartments and out of the reactor building.

According to preliminary assessments, the fuel located within the reactor building had a temperature of about $1600^{\circ} \mathrm{C}$. The calculated dynamics of the fuel temperature and fuel activity shortly after the accident were given in a 1986 report by Dr. Legasov.

The energy release shifted the 1000-MT reactor cover plate and relocated it in an upright position within the reactor well. All the fuel channels, the upper fipe interface and the lower water pipes were destroyed. The auxiliary systems of reactor cooling and biological shielding were destroyed and dewatered; the crane and refueling machine collapsed. The room that housed the main circulation pump electric motors was destroyed from the north side. The structures of the main circulation pump rooms and downcomer welts were unaffected.

The burning reactor became the source of the major radioactivity escape to the environment. Initial estimates showed that about $3-4 \%$ of the fuel was blown out from the unit either in the form of fragments or fine particles.

To stop this process, to mitigate the graphite fire, and to cool the core debris, a variety of heat absorbing and filtering materials with the total weight of 5000 MT was dropped onto the reactor vault from helicopters. The materials included: boron carbide (40 MT), dolomite (800 MT), clay and sand (800 MT) and lead (2400 MT). As a result, the reactor well was sealed off by a Jayer of loose material and the radioactivity release rate fell to some hundred $\mathrm{Ci} / \mathrm{d}$. To decrease the core temperature and to block oxygen access to the cone, nitrogen was fed into the lower part of the building.

These measures arrested the increase of temperature in the reactor vault. Since then, the steady decline of the temperature began, and stable convective air flow was established through the core space into the atmosphere above. To prevent the possibility of the interaction of the core melt with the concrete 
reactor floor plate, a flat heat exchanger was installed beneath the foundation of the building. This, however, was unnecessary because the concrete plate was not melted through.

By the end of May 1986, the maximum temperature observed in the core space was brought down to about $100^{\circ} \mathrm{C}$, and since then continued to decline steadily.

Since the regular measurement systems in the unit had been completely broken, immediate diagnostics of the reactor state were organized. This included radioactivity measurements and infrared photography of the unit site from airplanes and helicopters, as well as the chemical composition analysis of the gases evolved. Later on, probes were inserted into the surviving piperuns, and sensors were installed in the dewatered pressure suppression pool (under the reactor) to measure neutron and heat fluxes, gamma radiation and temperature. It was found that the temperature of the fuel fragments did not achieve that of fuel melting. Since June [1986], the temperature in the area of the reactor foundation did not exceed $45^{\circ} \mathrm{C}$.

Preliminary assessment of the fuel distribution on the plant site showed that some part of the core inventory had been located in the compartment under the reactor and in the reactor well. Still another part had been ejected into the reactor hall and the rooms containing steam-water lines. In a compartment beneath the reactor, a large amount of melted sand was found; this contained about $2 \%$ of the fuel inventory. In August 1986, stationary sensors were installed to measure gamma radiation fields, temperature, air speed and heat fluxes.

The sensors indicated:

$\begin{array}{ll}\text { Gamma radiation intensity }(\mathrm{R} / \mathrm{h}) & 10^{4} \\ \text { in the reactor vault } & 10^{3}-10^{5} \\ \text { in the area of the reactor foundation and around the core space } & \\ \text { Temperature interval }\left({ }^{\circ} \mathrm{C}\right) & 30-50 \\ \text { Convective heat flux }\left(\mathrm{kW} / \mathrm{g}^{2}\right) & 10 \\ \text { Conductive heat flux }\left(\mathrm{W} / \mathrm{m}^{2}\right) & 200 \\ \text { Air speed (m/s), vertical } & 0.8-1.0 \\ \text { horizontal } & 0.5-0.8\end{array}$




\subsubsection{Entombing Unit 4 for Localization of Damaged Fuel and Radioactive Material}

To reduce radiation levels and to ensure safe conditions for the workers, Chernolyy-4 was entombed using a method of stepwise sealing off of the damaged unit from its periphery to the core. The construction sequence of the "sarcophagus" containment structure included:

- concreting the area around the unit

- installing initial outer walls along the unit perimeter (at first a load-bearing metal frame was erected, and then it was concreted with the help of remotely controlled concrete pumps)

- installing a protective partition wall (concrete, flame-proof) between units 3 and 4

- backing up the surviving monolithic wall (on the west side of the unit) with a metal frame, with subsequent concreting of the inner space between the wall and the new metal frame

- creating a cascade wall from the north side of the unit

- covering the roof of the main hall, the de-aerator room and damaged compartments of the machine room.

It was reported in a NOVA broadcast that $340,000 \mathrm{~m}^{3}$ of concrete and 3,000 tons of steel were used to build the "sarcophagus" containment structure, which was 28 stories high (NOVA 1989).

The ventilation systems of the enclosure (natural convection and mechanical) are intended for residual heat removal. The exhaust ventilation system consists of seven fans of $220,000 \mathrm{~m}^{3} / \mathrm{h}$ capacity (with three fans operating). The natural ventilation proceeds through the bypass of the exhaust ventilation system and has the capacity of $12-35 \times 10^{3} \mathrm{~m}^{3} / \mathrm{h}$, depending on weather conditions. Air exhausts are purified at the regular filtering plant of Unit 4, and clean air is vented to the atmosphere through a standard ventilation stack $150 \mathrm{~m}$ high.

A system for cooling the reactor foundation slab consists of registers [cooling channel?] installed under the slab. The space between the register pipes is filled with graphite to improve heat removal. The registers are connected to the mechanical ventilation of Unit 3 . The cooling system 
installed in the concrete slab under Chernobyl-4 has not been turned on because it has not been needed, said Valery Legasov in April 1987 (Nucleonics Week 4/87a).

The operation of the cooling system and the temperature regime of the foundation are monitored with a system of 200 temperature sensing elements.

\subsubsection{Radioactive Waste Management}

Arisings of "high-level" solid wastes on the Unit 4 site and the surrounding area consisted of a soil layer from the ground (150-200 mm thick), equipment, fragments of structures and graphite blocks, fine fuel particles, etc.

The following solutions were accepted for the disposal of the "highlevel wastes":

- The most active wastes were buried within the unit construction in the course of entombing.

- The rest of the wastes were disposed of by shallow burial.

- Wastes of low and medium activity were transferred to a number of storage modules which are being built and put to use as necessary.

Wastes of categories 1 and 2 are buried in shallow, trench-like facilities, $100 \mathrm{~m}$ long (at the base), $16 \mathrm{~m}$ wide and $4 \mathrm{~m}$ deep. The base and the walls of the facility are shielded with a $0.5-\mathrm{m}$-thick layer of clay and waterproof film. The loaded module is covered with a clay layer $0.5 \mathrm{~m}$ thick and with a waterproof film. The facility site is surrounded with leakage control wel1s.

Solid wastes of category 2 are stored in ferroconcrete forms with $150 \mathrm{~m}^{3}$ capacity, which are installed on a concrete foundation, equipped with protective screens and precipitation collectors. The forms, filled with alternate layers of waste and concrete, are sealed off with ferroconcrete covers.

Trees that were highly contaminated were cut down and buried in concrete bunkers, cars and trucks were buried, and 60,000 buildings were washed down in an effort to reduce the spread of radioactivity (NOVA 1989). 
The Soviets recently stated that post-Chernobyl cleanup is entering a second long-term phase distinct from the more ad hoc and emergency measures taken so far. International researchers will be able to study cleanup issues when the much-talked-about accident research center in the critical zone opens (planned for early 1990), and when "Kombinat" (the monitoring-and-research unit of the accident amelioration team) is reconstituted as a separate enterprise able to accommodate foreign scientists. USSR Deputy Director of the World Association of Nuclear Operators (WANO) Vladimir Ivanovich Komarov said the new Kombinat will remain independent of government and that it will "be ready to consider any (research) proposal for the future" (Nucleonics Week $11 / 89 a)$.

The cleanup could be separated into the intensive stage from 1986 to 1989 and the long-term stage from 1989 to the year 2000. The first stage is aimed at the accident sectors most dangerous to human life. "Contaminated objects were localized in the 'reddish forest' and 'old construction base' sectors, with a total area of 300 hectares," and more than 4-million $\mathrm{m}^{3}$ of slightly active solid radioactive waste was temporarily located at some 800 points in the nearer zone of the Chernobyl plant, Komarov said (Nucleonics Week 11/89a). Contaminated soil is reported to have been disposed of in clay-lined pits, with two meters of clay below and one meter above the waste. Water access is prevented by dikes. Their monitoring efforts, so far, have shown no leakage (Lehman 1989).

The Soviets have stated that there is no technology available yet that can accomplish the goal of the second phase: permanent storage of the 4-million $\mathrm{m}^{3}$ of waste in temporary storage near the Chernobyl station and the waste outside the 30-kilometer zone, where cesium-137 and strontium-90 fallout in high concentrations covers 10,000 square miles and would require removing soil $3 \mathrm{~cm}$ deep.

The transition of radionuclides to soluble forms in natural objects can already be observed in Byelorussia, Komarov said. "All the pasture land in the zone of rigid control is gradually becoming 'dirty.' The operational methods of decontaminating natural objects (ploughing and removing contaminated surfaces) are gradually coming under suspicion. The processes of 
contamination dilution proceed more rapidly than was assumed, "he said (Nucleonics Week 11/89a).

Table 6.3 shows the estimated radionuclide release, calculated on May 6 , 1986, allowing for decay of short-lived radionuclides (Nuclear News 10/86). The Kombinat has installed a network of 100 sensors covering $2800 \mathrm{~km}^{2}$, which feed data to a computer center worth $\$ 500$ million, purchased with some of the contributions received from various countries. Another waste management activity is the construction of a 30 -meter-deep, I-foot-thick slurry wall around the Chernobyl station cooling pond, which is reported to be 15,000 meters long. As of the spring of 1987, 136 dikes and dams had been built to prevent run-off from rivers (Lehman 1989).

TABLE 6.3. Estimated Release of Radionuclides from the Chernobyl Accident

\begin{tabular}{|c|c|c|}
\hline Nucl ide & $\begin{array}{l}\text { Released Activity } \\
\text { (MC } \mathbf{i}) \\
\text { by May 6, } 1986\end{array}$ & $\begin{array}{c}\text { Released } \\
\text { Percentage } \\
\text { by May } 6,1986\end{array}$ \\
\hline $133 \mathrm{xe}$ & 45 & up to 100 \\
\hline $85 m^{8} \mathrm{Kr}$ & -10 & up to 100 \\
\hline $13 Y_{1}^{r}$ & 0.95 & up to 100 \\
\hline $132 \frac{1}{\mathrm{Te}}$ & $\begin{array}{l}1.3 \\
1.3\end{array}$ & $\begin{array}{l}20 \\
15\end{array}$ \\
\hline $134 \mathrm{Cs}$ & 0.5 & 10 \\
\hline${ }_{00}^{137} \mathrm{CS}$ & 1 & 13 \\
\hline${ }_{95}^{99} \mathrm{Mo}$ & 3 & 2.3 \\
\hline${ }_{103}^{95}$ & 3.8 & 3.2 \\
\hline $106^{\mathrm{Ru}}$ & 3.2 & 2.9 \\
\hline $140_{\mathrm{Ba}}^{\mathrm{KU}}$ & $\begin{array}{l}1.6 \\
4.3\end{array}$ & $\begin{array}{l}2.9 \\
5.6\end{array}$ \\
\hline $141_{\mathrm{Ce}}^{\mathrm{Da}}$ & 2.8 & 2.3 \\
\hline $144 \mathrm{Ce}$ & 2.4 & 2.8 \\
\hline${ }_{230}^{238} \mathrm{Pu}$ & $0.8 \mathrm{E}-3$ & 3.0 \\
\hline${ }^{239} \mathrm{Pu}$ & $0.7 \mathrm{E}-3$ & 3.0 \\
\hline${ }_{240}^{240} \mathrm{Pu}$ & $1 \mathrm{E}-3$ & 3.0 \\
\hline${ }_{24}^{241} \mathrm{Pu}$ & 0.14 & 3.0 \\
\hline${ }^{242} \mathrm{Pu}$ & $2 \mathrm{E}-6$ & 3.0 \\
\hline${ }_{80}^{242} \mathrm{Cm}$ & $2.1 \mathrm{E}-2$ & 3.0 \\
\hline $90^{3 r}$ & 2.2 & 4.0 \\
\hline${ }^{2} 39 r$ & 0.22 & 4.0 \\
\hline & 1.2 & 3.2 \\
\hline
\end{tabular}

Note: Estimated error $\pm 50 \%$ 


\subsubsection{Research Program to Assess Entombed Unit 4 Condition and Core Debris Behavior}

The enclosure of Unit 4 was put into operation on December 1986. Since that time, the condition of the unit entombment, as well as the core debris and other radioactive materials, has been closely watched and analyzed. For this purpose, a complex research program has been developed and is being implemented. The program includes the following parts:

1. "Condition" - aimed at diagnosing the current state of the unit and predicting its future behavior based on data gathered from numerous sensors that are installed along the perimeter of the unit and in the inner space close to the bulk of fuel.

2. "Subcriticality" - experimental and calculation work with the objective to deveiop preventive measures against a chain reaction in case of any movement or eventual destruction at the unit site. The work is done by obtaining samples from boring 30 special holes from the decontaminated compartments toward the zone of fuel location. The samples, containing fuel and construction materials, are studied thoroughly (metallography, physical-chemical properties, etc.). The boreholes are also used to perform visual inspections (with TV or optics), and to make assessments of radiation, neutron, gas and heat flux parameters.

3. "Reliability" - studies aimed at assessment of the long-term stability of the entombed unit, especially its structural elements.

In accord with geodesic observations, the settling of the buildings did not exceed the existing specifications, which is evidence of structural stability. According to the conclusion of the experts, the main load-bearing metal structures should have a service life of not less than 30 years. Monitoring of the radiation dose rate, temperature and heat flux has confirmed that fuel has also achieved a stable condition.

An All-Union decommissioning program was set up in the summer of 1987 , with the Research Institute for Nuclear Power, Moscow, having the lead. Professor Abigan is the leader of this activity (Johnson 1989b).

\subsubsection{Cancellation of Units 5 and 6}

lnits 5 and 6 of the Chernobyl nuclear power station will not be completed, as stated by Andronik Petrosyants, chairman of the USSR State Committee for the Utilization of Atomic Energy (GKAE), in April 1987 in Moscow. 
Valery Legasov of the Kurchatov Atomic Energy Institute, a leader in the Chernobyl recovery effort, said on April 24, 1987, in Paris, France, that a decision on whether to pursue construction of the last pair of units at Chernobyl would "depend to a large extent on the quality of decontamination" possible on the construction site. Thus, it can be deduced that the contamination was considered too problematic for the long-term presence of a large construction force at the site (Nucleonics Week 4/87a).

\subsubsection{Impacts on Local Public}

In an interview in the Paris Daily Le Monde on April 24, 1987, Valery Legasov said the maximum radiation levels at the Chernobyl site was measured in milliroentgen per hour, compared with severa? roentgen per hour or more just after the accident. At present, radiation exposure rates at the Unit 1 and Unit 2 sites (by the staff facilities and office building) are in the range of $0.5-0.7 \mathrm{mR} / \mathrm{h}$ and $3-7 \mathrm{mR} / \mathrm{h}$, respectively. The aerosol concentration is $10 \%$ of that permissible for RBMKs, and the average daily exhausts through the ventilation stack are ten times below that accepted for normally operating power plants.

Detailed data from "practically every European country" confirm the general conclusion that the health effects of the Chernobyl radiation will not be medically discernible, Legasov said. The Soviets estimated that some $300 \mathrm{mil}$ lion people in Europe will receive a collective dose "not more than $1.3 \%$ above background levels during 50 years as a result of the Chernobyl accident. International experts of the United Nations Committee on the Scientific Effects of Atomic Radiation (UNSCEAR) have come to similar conclusions, Legasov said. In the USSR, 360,000 people who "could have been exposed" to much higher radiation doses are under permanent medical control, but "no deviation (in their health) due to radiation has been discovered," he said. of 237 persons affected by radiation disease, 28 died [later changed to 31 ], seven were discharged from their jobs with disability benefits, 65 have returned to work, and the rest are completing medical treatment, he said (Nucleonics Week 4/87b).

More recent information provides further details on human exposure. Because the direction of winds in the days immediately after the accident 
described a 360-degree circle, the initial decision was made to evacuate the populaion from a $30-\mathrm{km}$ zone around the plant. Eventually, areas with dose rate levels of $5 \mathrm{mR} / \mathrm{h}\left(50{ }_{\mu} \mathrm{Sv} / \mathrm{h}\right)^{(a)}$ or higher were established as the zone to be evacuated, with a special "reserved" zone inside the areas with $20 \mathrm{mR} / \mathrm{h}$ $(200 \mu \mathrm{jv} / \mathrm{h})$ or greater radiation levels. The basis for long-term radiation doses now adopted by the USSR Ministry of Public Health is to limit lifetime doses to people in the affected regions to less than 35 rem (.35 Sv). The total area contaminated with cesium-137 at $15 \mathrm{Ci} / \mathrm{km}^{2}$ or more is about $10,000 \mathrm{~km}^{2}$. During the first year after the accident, a total of 186 population centers (with a total of 116,000 people) were evacuated (Nuclear News $5 / 89)$.

To date, the populations of 14 villages have been returned (12 in Byelorussia and 2 in the Ukraine). The radiation levels in the southern part of the $30-\mathrm{km}$ zone are such that there are still more than 10 villages where a safe return of the population may be possible. Work to monitor radioactivity and agricultural measures is continuing in these areas during 1989, and more than 10,000 people will be involved in decontamination work (Nuclear News $5 / 89)$.

According to interviews with Soviet officials at the Chernobyl site, a total of 135,000 people were evacuated, 237 were treated for acute radiation sickness and 1,950 children were born after the accident from pregnant women in the evacuation zone. Deaths from radiation were highest among the firemen, who were the first on the scene of the accident and worked to put the fires out (NOVA 1989).

According to an August 21, 1989, TASS dispatch from Minsk, 100,000 more people in Byelorussia may have to be rehoused as a result of continuing concerns about radiation levels following the Chernobyl accident. The dispatch said the additional cost of dealing with this and other recovery measures, estimated at 10 billion rubles, was almost equal to the republic's entire annual budget. There have also been reports that evacuation of about

(a) Dose rate figures in the article are quoted as roentgens, which for gamma radiation are effectively the same as rem and have been converted here into the equivalent sieverts. 
3000 people from 12 villages in the Bryansk region (Russian Federal Republic) is planned (NEI $10 / 89, p .12$ ). Although it was recently reported that at least 250 people involved in the accident, rescue and cleanup operations at Chernobyl have died (Washington Post 1989e), the Soviets claim that this includes natural causes of death and continue to only list 31 deaths from the accident. The Kombinat (see Section 6.6.5) is responsible for developing a new town called slavutich, where 8,000 people now live. The towns of Chernobyl and Pripriat may not be reinhabited for another 70 years (Lehman 1989).

The Soviets recently told of the successful use of the iron compound Prussian Blue in foodstuffs to reduce contamination following the Chernobyl accident (Nucleonics Week 11/89b).

\subsubsection{Cost of Accident Recovery}

The Politburo of the USSR stated that the accident recovery program for the Chernobyl accident cost $\$ 7$ billion (U.S.), and the replacement power costs were an additional $\$ 7$ billion. The recovery costs include $\$ 1.6$ billion for compensation and additional costs for construction of houses and apartments for the 135,000 evacuees (Nucleonics Week $1 / 88$ ). 


\subsection{FUEL REPROCESSING (EXCLUDING HIGH-LEVEL WASTE PROCESSING AND STORAGE)}

Information on spent fuel reprocessing in the Soviet Union is given in this section. Included are processing facilities and s,rstems and related waste management information. [Note: Information on management of high-level wastes from reprocessing is given in Section 8.]

\subsection{SUMMARY}

During the creation of a Soviet nuclear industry in the 1940s, scientists at the Khlopin Radium Institute in Leningrad developed the technology of plutonium extraction from irradiated fuel. By 1950, the USSR a]ready possessed the industrial technology to extract plutonium-239 from irradiated natural uranium. In 1952, work started to perfect a method of reprocessing the irradiated fuel that would be discharged from the first nuclear power plant in Obninsk (Semenov 1983). Subsequently, information on reprocessing was limited to references to "ongoing research" and some "pilot-plant" studies. In 1989, the Soviets indicated that a reprocessing plant, near Chelyabinsk [Kyshtym], was operational in 1949 for reprocessing production reactor fuel, and then for reprocessing VVER-440 and naval reactor fuel starting in 1978, according to a report by the Natural Resources Defense Council (NRDC). Recent information also mentioned a $1500-M T / y r$ reprocessing plant that was being constructed as the first of several modules. Subsequentiy, it was announced that the 1500-MT reprocessing unit, near Krasnoyarsk, was "postponed indefinitely." There are no current plans to reprocess RBMK fuel and there are no plans for direct disposal of the RBMK spent fuel.

The first fuel reprocessing method was based on slightly soluble sodium uranyl acetate precipitation from nitric acid solutions. Fuel reprocessing in the USSR now utilizes conventional chop-leaching of the spent fuel followed by PUREX-type solvent extraction of uranium and plutonium. "Dry" [i.e., pyrochemical] reprocessing has been under way in Dmitrovgrad since 1984 and a larger unit is now being built, according to the French nuclear agency. Perhaps significantly, much research is being done on partitioning high-level waste into element fractions. The Soviets appear to have the technology for 
removal of gases released during reprocessing operations; however, there is no indication that it has been implemented.

\subsection{POLICY AND STRATEGY}

The Soviets have not announced their shedule for additional reprocessing capacity. Soviet reprocessing technology is similar to that used by western nations: chop-leach head-end and PUREX solvent extraction. The Soviets have emphasized the recovery of transplutonium elements and selected fission products. Research and development includes studies of process and equipment optimization, recovery of by-products from wastes, and reprocessing of FBR (BN) reactor fuels (Nuclear Europe 1-2/88).

The USSR has reprocessed military spent fuel for many years and is a]so reprocessing civi]ian spent fuel from VVER-440 reactors [at Kyshtym], including fuel from Finland's two Soviet-built WVER-440 reactors (Cooley 1989; Nuclear Fuel 11/87), as well as naval reactors (NRDC 1989).

The USSR policy has been to recover and recycle uranium and plutonium from VVER-1000 power reactors on an industrial scale. Several reprocessing plants were planned, each with a capacity of $1500 \mathrm{MTU} / \mathrm{yr}$, to be erected one after the other according to need. The need for reprocessing is determined by the plutonium requirements for the Soviet FBRs (Nuclear Europe $1-2 / 88$ ).

This policy appears to have changed recently when the Soviets indefinitely postponed completion of the reprocessing plant in Siberia. Construction of the plant had been going on for at least 12 months when the decision was made in mid-1989 to suspend the project. The plant, near Krasnoyarsk on the Trans-Siberian Railway, was reported in July 1989 to be $30 \%$ complete. It was to have reprocessed spent fuel from 1,000-MW Soviet-design PWRs (VVER-1000s) and "other reactors," Soviet officials have said (Nuclear Fuel 10/89a).

Soviet officials also said that the existing, smaller reprocessing facility, built originally for defense purposes at Kyshtym in the southern Ural mountains near the city of Chelyabinsk, is much larger than western experts earlier have believed and that it has recovered substantial amounts of plutonium from Soviet PWRs over the last 10 years. A Soviet official said that 
the Kyshtym plant actually did reprocess 400 MTHM of spent PWR isel one year, but that over the plant's 10-year "civilian" lifetime, throughput has averaged about $200 \mathrm{MTHM} / \mathrm{yr}$, during which time they recovered about 20 MT of plutonium.

Originally, PWR spent fuel was reprocessed in anticipation of a generation of large breeder reactors that were to follow the existing $B N-600$ at Beloyarsk, which is not far from Chelyabinsk. However, due to a slowdown in the Soviet fast reactor program compared with 1970 s plans, the USSR announced as long ago as 1982 that it was delaying large-scale reprocessing and building additional away-from-reactor spent fuel pools. "There is a lot of research going on" in the USSR into plutonium recycle, Alexander Protsenko said at a 1989 press conference in Vienna. However, manufacture of mixed-oxide (MOX) fuel and recycle of plutonium in Soviet reactors "has been deferred at least until early next century," he said.

Protsenko later said that no final decision had been made on whether or when the remaining Soviet spent fuel will be reprocessed. Both the existing $400 \mathrm{MTHM} / \mathrm{yr}$ reprocessing plant at Kyshtym and the now-suspended full-scale [1500 MTU/yr] plant use the PUREX solvent extraction separation process used in all reprocessing facilities in the West. Soviet officials said that spent RBMK fuel is too high in fertile plutonium isotopes and too low in residual uranium-235 to warrant reprocessing presumably because, to generate electricity, the fuel has been taken to higher burnups like those typical in PWRs (Nuclear Fuel 10/89a).

Thus, the current policy indicates that there are no plans to reprocess RBMK fuel, as well as no plans for direct disposal of the RBMK fuel (Johnson 1989b). The final disposition of RBMK spent fuel remains undetermined at this point.

\subsection{FUEL REPROCESSING FACILITIES AND SYSIEMS}

\subsubsection{Facility Types and Characteristics}

The capacity of the current USSR reprocessing piant (at Kyshtym), which processes spent fuel from the smaller Soviet power reactors [VVER-440s], is 400 MT/yr (Cooley 1989). The NRDC reported in July 1989 that a "chemical 
separation plant" was located at Kyshtym, based on a visit to that site. The NRDC reported that in 1978 the plant at kyshtym shifted from processing military production reactor fuel to processing fuel from Soviet WVER-440 power reactors and naval reactors (NROC 1989).

Additional information on fuel reprocessing in the Soviet Union was released later in 1989. The "radiochemical" plant at Chelyabinsk [Kyshtym] was operational in 1949 to extract plutonium from military production reactors. The first reprocessing method used sodium uranyl acetate precipitation from nitric acid solutions [this explains the sources of acetate implicated in the 1957 accident at Kyshtym, discussed in Section 8.7] (Drozhko et al. 1989). This was followed by an ion-exchange process (Nikipelov et al. 1990). The Soviets' basic fuel reprocessing methodology now appears to be the PUREX liquid extraction process preceded by chop-leaching of the fuel. In addition, separation of transplutonium elements, some rare earths, strontium, cesium, palladium and technetium from high-level wastes is [apparently] carried out or planned for (Pushkov 1984). Separated cesium is used in largescale industrial applications such as sterilization and "storage of food stuffs," while strontium is used for "navigation gauges and instruments in remote locations" (Lehman 1989).

It was further reported that in 1982, when spent fuel in casks was received at the reprocessing plant [at Kyshtym], it was unloaded and placed in lag storage, according to its fissile content, which was measured by gamma and/or neutron radiation levels. When ready for reprocessing, a basket full of spent fuel was moved to the hot cell where the end fittings were cut off using a circular saw or arc saw. The end fittings were sent to burial, and the remainder of the spent fuel assembiies were transferred to the cutting machine for cutting into short pieces (Dubrovsky et a1. 1982).

As of 1982, dissolution of the chopped spent fuel rods was done in a continuous vibrating dissolver or in a batch dissolver using a pneumatic can discharge. Dissolver solution was clarified using a cartridge of metalceramic filters and a centrifuge. The separation of uranium from plutonium, as reported in 1982, was done in the first PUREX-type solvent extraction cycle using a chemical reducing agent for plutonium. The final plutonium solvent 
extraction cycles may utilize a "refluxing type of flowsheet" to improve plutorium purification and to aid in removing valuable elements, indicated to be rare earths and strontium, and possibly cesium and others. Mixer-settlers were used to carry out solvent extraction. Centrifugal contactors were also considered, but they required better manufacturing quality and more maintenance and repair. However, these contactors may be more desirable in the long run (Dubrovsky et al. 1982).

After solvent extraction, recovered plutonium was converted to plutonium oxalate, followed by calcining to plutonium dioxide. Recovered uranium as uranyl nitrate was converted to ammonium diuranate, followed by calcining to uranium dioxide. If mixed oxides are desired for recycle fuel, ammonium diuranate and plutonium hydroxide are mixed and calcined to the dioxides (Dubrovsky et a1. 1982; Sedov et a]. 1988). Concentrates of rare earths and strontium were [apparently] separated from the first cyc]e raffinate solution. To accomplish this, the concentrated acidic high-level liquid waste solution was first partially neutralized. The rare earths were recovered by solvent extraction using tributylphosphate solvent, and strontium is recovered using di-(2-ethylhexy)-phosphoric acid (DEHPA) solvent in a diluent. More than $90 \%$ of the rare earths and $95 \%$ of the strontium were recovered (Dubrovsky et a). 1982).

A Soviet reprocessing plant [presumed to be Kyshtym] was visited by a journalist, apparently in early 1989, with mostly nontechnical information made available. A summary of the technical information is provided below (Chert rov 1989):

- The Director of the facility was V. K. Sazhnov.

- The facility's location was not identified, but it requires a long journey to reach it. The workers live in a specially built, wellarranged city that is located on the bank of a huge lake. The city, which used to be a "camp," is not on the map nor on railroad or airline schedules. Multi-story houses and well-filled stores are in the city. The city, which is fenced in, is a drive of "some distance" to the reprocessing facility. 
- A number of gas discharge chimneys [i.e., stacks] were seen, with smoke always pouring out of them. However, radioactive gases were reportedly reduced to a minimum by cleaning with rigid and safe techniques.

- Rail transport of spent fuel is preceded by about one hour by another train that provides for inspection of the track and roadbed. The special train is inspected every $150-200 \mathrm{~km}$. The wall s of the cask are $376 \mathrm{~mm}$ of steel.

- The railroad "corridor" of the facility was visited. An assembly of spent fuel that contains a "little more than $100 \mathrm{~kg}$ of fuel" was in a transport container that weighed approximately 10 MT. [Note that this is a very small "cask."]

- The spent fuel is removed from the cask [apparently in air] and placed in the lag storage pool with $20,000 \mathrm{~m}^{3}$ of water.

- After lag storage in the pool, the metal casing containing the fuel is separated. [It is not clear if this is spent fuel hardware, cladding hulls or baskets.]

- The spent fuel, apparently one rod at a time, is placed on a channel and cut with a mechanical saw that is handled by a manipulator. This can be observed through a lead glass shielding window.

- High-level waste is vitrified in a special, remotely controlled melter system. The melter system took 10 years to develop, and a second one is being built. The vitrified waste is poured into steel canisters, three of which are in turn placed into another container. The lid of the larger container is welded on and the container is moved to a storage area for monitoring for two weeks. From there the can is taken to a long-term storage room.

A new reprocessing plant to service the larger reactors (VVER-1000) had been under construction to have a capacity of $1500 \mathrm{MT} / \mathrm{yr}$ (Cooley 1989). The NRDC aTso mentioned, in its trip report from its visit to the Kyshtym site, that a large facility for storing and reprocessing VVER-1000 and other reactor fuels was located at Krasnoyarsk. The Krasnoyarsk reprocessing plant was expected to be operational in the late 1990s, and its construction was $30 \%$ complete by July 1989 (NRDC 1989). This now appears to have changed because the plant construction has been "indefinitely postponed" as discussed above.

An industrial-scale fuel reprocessing plant [now indefinitely postponed] for spent fuel from VVER-440 and WVER-1000 reactors was being constructed, as 
indicated by Sedov in 1988. It was also stated that the $p$ antit was aiso to reprocess fue] from RBMK reactors (Sedov et al. 1988). The planned new reprocessing plant was designed from experience in reprocessing fuel from WVER-440 reactors. The plant already has a reception area with a storage capacity of 3000 MT. The processing rate of the first phase of the plant was planned to be $1500 \mathrm{MTU} / \mathrm{yr}$. Subsequent phases were planned to add capacity in increments of $1500 \mathrm{MTU} / \mathrm{yr}$. In the head end, the fuel assemblies are broken up by removing the top and bottom pieces and by cutting up the fue] rods (Nuclear Europe 1-2/88). This is followed by dissolving the fuel in nitric acid, and filtering the solution in a "sleeve" of metal-ceramic filters (Sedov et al. 1988). The dissolution off-gases were to be scrubbed for retaining iodine, carbon-14, and krypton. The classic PUREX process, with three cycles, is used for recovery and purification of plutonium oxide and uranium nitrate (Nuclear Europe 1-2/88).

Basic principles for design of fuel reprocessing facilities include "unitizing" of equipment systems for easy remote replacement, development of a critically safe dissolver feed centrifuge and critically safe centrifugal solvent extraction contractors, computerized design, automated operation, etc. Details of selected hardware and some facitity design features have been described. (Shevelin et a1. 1988).

The fue] reprocessing facilities are [apparently] maintained by direct contact, with redundancy of some key equipment and remote replacement of some equipment (Dubrovsky et al. 1982).

\subsubsection{Research and Development}

Research and development studies were under way in 1982 for separating the trivalent lanthanides, strontium and cesium directly from high-level liquid wastes with 2-3 molar nitric acid. Processes were being studied that use phosphine dioxide and bidentates as extractants to recover rare earths, while the use of dicarbolide compounds were considered for recovery of cesium and strontium. Also, as of 1982, future national demands indicated the desirability of recovering technetium and palladium from high-level liquid wastes (Dubrovsky et aT. 1982). 
Research and development is being carried out in (radioactive and nonradioactive) laboratory tests on reprocessing of spent mixed-oxide fuel from FBRs. Experiments have been carried out in pilot plants with fuel exposed to 60,000 MWd/MT, aged about two years. Two-cycle PUREX-type solvent extraction studies have been performed in mixer-settlers and centrifugal contactors. Tests were done on the use of uranium-IV for partitioning of plutonium from uranium, degradation of the extractant, decontanination of the two product streams, scrubbing of fission products, tritium distribution in the process, and buildup and management of solids in solutions, etc. The conclusion regarding centrifugal contactors is that they are favored over other contactors for this service. Feed flow rates in the studies were up to about one liter per hour, which is equivalent to a processing rate of about $4.8 \mathrm{~kg} / \mathrm{d}$ of heavy metal (Renard et al. 1988).

According to the French CEA, the USSR was operating a dry [i.e., pyrochemical] reprocessing "mini-pilot plant" (actually a large hot cell called Fregate-1) at Dimitrovgrad in 1984. The feed for the facility was spent fuel from the BOR-60 experimental FBR. A larger pilot facility, called Fregate-2, was under construction with a capacity of $3 \mathrm{~kg} / \mathrm{h}$ of short-cooled spent fuel. The Soviets had not yet selected an industrial process for reprocessing breeder reactor fuel. The process under consideration for a joint project with the French involves melting of steel components at $1500^{\circ} \mathrm{C}$, dissolving the oxide fuel in fluoride, and separating the resulting uranium hexafluoride and plutonium hexafluoride by crystallization. "Following resublimation, the uranium and plutonium would be separated by reduction to the tetrafluoride solids, while fission products would separate out naturally" (Nuclear Fuel $6 / 84)$.

\subsection{FUEL REPROCESSING WASTE MANAGEMENT}

Available information on activities and systems for the general management of radioactive wastes from reprocessing in the Soviet Union is given in this section. Final conditioning and management of all wastes, including those from fuel reprocessing, is covered in Sections 8, 9 and 10 . Final conditioning and storage of high-level wastes is covered in Section 8 , 
conditioning and storage of low- and intermediate-level wastes is addressed in Section 9, and disposal of all wastes is covered in Section 10.

\subsubsection{Systems and Activities}

As of 1982, iodine 129 removal from dissolver off-gases was reported]y done by the use of mercuric nitrate solutions, liquid silicones or caustic solutions. Then the iodine passed through an adsorber using silver salts. The caustic scrubbing also removed carbon-14. More than $95 \%$ of the tritium remained in the solvent extraction raffinate and then followed the nitric acid and condensate systems (Nikiforov et al. 1981b; Dubrovsky et al. 1982).

As of 1988, the dissolver off-gas streams undergo treatment in a distillation tower that uses a caustic solution reflux. The tritium is removed with condensates, resulting in the regeneration of nitric acid for reuse (Sedov et al. 1988).

The quantities of liquid high-level, intermediate-level, and low-level wastes generated at fuel reprocessing plants were given as $0.7-1.0,3-5$, and 50-100 $\mathrm{m}^{3} / \mathrm{MTU}$, respectively (GKAE 1978).

\subsubsection{Research and Development}

The apparent scheme in 1981 for cleanup of fuel reprocessing off-gases involved removal of aerosols, radioiodine, and nitrogen oxides first. Then the gas stream was to be dried and decontaminated of carbon monoxide, then passed through a separation unit for removal of radiokrypton (Nikiforov et al. $1981 b)$.

Removal of krypton-85 from fuel reprocessing plants was being studied as of 1981. The apparent preferred process was cryogenic distillation. It was conceived that the radiokrypton gas would be stored in pressurized containers for 150-200 years to allow for decay before releasing the materials to the environment (Nikiforov et al. 1981b).

Experimental verification of removal of krypton from gas streams is being carried out using low-temperature adsorption on activated carbon, absorption in freon, and cryogenic distillation (Sedov et al. 1988). 
As of 1978, R\&D studies were under way for recovery of tritium in spent fuel during fue1 reprocessing. Two promising concepts were identified:

1) release of about $99 \%$ of the tritium from punctured spent fuel by oxidation using humid air or oxygen at about $600^{\circ} \mathrm{C}$ for $8-12$ hours; the resulting concentrate would have a volume of about 5-10 1/MT; and 2) recycle and concentration of about $95 \%$ of the tritium in the aqueous phase from solvent extraction into a volume of about 100-500 1/MT (INFCE WG 7 1978). 


\subsection{HIGH-LEVEL LIQUID WASTE PROCESSING AND STORAGE}

This section presents information on initial treatment and storage of high-level liquid wastes generated at Soviet fuel reprocessing plants. It also presents information on final conditioning and storage of conditioned high-level wastes. Information on the 1957 "Accident in the Urals" is also provided.

\subsection{SUMMARY}

The reference Soviet high-level waste (HLW) management plan is to store the high-level liquid waste (HLLW) in tanks for 3-5 years, then process it into glass logs in canisters with a volume of 100-150 1/MT of spent fuel reprocessed. The glass canister is then kept in air-cooled storage for 20-60 years followed by permanent disposal in a deep geologic repository. Vitrification may also be used for some fractions of the HLW streams resulting from partitioning activities. Vitrification research started in the $1950 \mathrm{~s}$, and a pilot plant capable of processing about $100 \mathrm{l} / \mathrm{h}$ of simulated $\mathrm{HLW}$ solutions has been operational for 10 years (at Kyshtym). A $5001 / h$ (feed rate) fully radioactive facility (also at Kyshtym) operated in 1987-1988 and has produced 160 MT of HLW phosphate glass. Problems with the glass melter electrodes have caused this radioactive facility to shut down, but a new design and plant are being developed. Perhaps significantly, much research is being done on partitioning $H L W$ into element fractions.

The Soviets are studying a wide variety of waste forms for containing HLW, with the primary emphasis on phosphate and borosilicate-based glasses. Aluminophosphate and borosilicate glasses are also used to contain cesium and strontium wastes, respectively. A variety of ceramic waste forms, including "synthetic mineral" types, have been studied as well as metal matrix waste forms. In parallel, many different processes are also being studied to produce these waste forms, and transmutation is being assessed as a treatment method for selected waste streams.

In the summer of 1989, the Soviets acknowledged an accident involving an explosion in a HLW storage tank at Kyshtym in 1957. 


\subsection{POLICY AND STRATEGY}

System studies have been carried out to optimize the conditions for management of $\mathrm{HLW}$. The range of overall optimum conditions is: 1) interim storage of HLLW for 3-5 years before vitrification ["although 20-30 years of HLLW (storage) is permissible" (Nikiforov et al. 1988)], 2) control the volume of vitrified wastes to 100-150 1/MT, 3) size the diameter of the cylindrical canisters for vitrified $H L W$ to between $30-60 \mathrm{~cm}$, and 4) provide interim storage of the vitrified $\mathrm{HLW}$ for 30-60 years (20-30 years, according to Drozhko et al. 1989) before disposal. The main reasons for the long-term interim storage are to reduce the heat before disposal and allow time to prove the safety of the disposal concept (Sedov et a1. 1988). The Soviets are also pursuing the partitioning of transuranium elemerits from HLW as part of their strategy (Nikiforov et al. 1989).

In 1989, the Soviets expressed interest in the Australian Synroc waste solidification process (Nuclear Waste News 11/89).

\subsection{HIGH-LEVEL WASTE QUANTITIES}

The quantities of liquid high-level, intermediate-level, and low-level wastes generated at fuel reprocessing plants were given as 0.7-1.0,3-5, and 50-100 $\mathrm{m}^{3} /$ MT of uranium, respectively (GKAE 1978).

\subsection{HIGH-LEVEL LIQUID WASTE TREATMENT AND STORAGE}

Information on initial treatment and storage of HLLW from fuel reprocessing is given in this section. Information on final conditioning and storage of solidified $\mathrm{HLW}$ is given in Section 8.5 .

\subsubsection{Facilities and Systems}

In 1978, it was stated that in spite of intensive research on HLLW solidification processes, interim storage of liquid wastes is used (GKAE 1978, p. 60). HLLW is presently stored, after concentration in the reprocessing plant, in stainless steel tanks equipped with cooling coils (NEI 6/88b).

Y. P. Velikhov, Vice President of the Soviet Academy of Sciences, broke the silence in December 1988 on the nuclear accident at a military complex in 
the Soviet Urals in 1957-1958 and stated that an accident had occurred. Velikhov stated that he would try to find out what happened. In addition, a Swedish researcher, C. Larsson, made public that satellite photographs showed that the accident may have been worse than the 1986 Chernobyl accident (Kyodo 12/88). This accident, which involved the storage of $H L W$ at the Kyshtym site, is discussed in detail in Section 8.7.

\subsubsection{Description}

As of 1981, HLLW was concentrated by evaporation in a natural circulation evaporator. The concentrated wastes were put into interim storage in stainless steel tanks [thus, the wastes are assumed to be acidic] and provided with devices for waste heat removal, air purges for hydrogen dilution, and outlets for emergency waste discharge, etc. (Pushkov 1984; NEI 6/88b). These tanks have to be replaced about every 20-30 years (Nikiforov et al. 1981a, $1988)$.

The tanks for interim storage of HLLW were sized to store from several hundred to twelve hundred cubic meters of wastes in each. They were located in groups that hold a total of about $7500 \mathrm{~m}^{3}$. The vertically oriented cylindrical tanks were contained inside concrete vaults lined with stainless steel, with leakage collection and monitoring sumps. The tanks had internal cooling coils, air-driven circulating systems, and air purges to dilute the hydrogen gas levels. The waste temperature was 1 imited to $50^{\circ} \mathrm{C}$ (7ater indicated to be 50-60 ${ }^{\circ} \mathrm{C}$, Nikiforov et a1. 1989) to reduce tank corrosion and evaporation. The minimum depth to groundwater below the storage tanks was given as $10 \mathrm{~m}$ (GKAE 1978, pp. 61, 65). Nikiforov noted in 1988 that the HLLW storage tanks had a volume: of "a few tens to a few hundreds of cubic meters" (Nikiforov et al. 1988). Storage up to 25-30 years is permissible in double-walled stainless steel tanks having special trays to collect leaks due to corrosion. If longer storage is required, the waste is transferred to "new reservoirs, "where the bottom must be not less than $4 \mathrm{~m}$ above the groundwater level (Nikiforov et al. $1989)$. 


\subsubsection{Waste Characteristics}

As of 1978 , the HLLW stream from WVER fuel reprocessing contains about $1.5 \%$ of the original uranium and about $3 \%$ of the original plutonium. The concentrated solutions contain about $1,000 \mathrm{Ci} / 1$, including about $2 \mathrm{Ci} / 1$ of a)pha radioactivity (GKAE 1978, pp. 13, 59).

\subsubsection{Research and Development}

The development and testing of extraction methods for the recovery of actinides from HLLW appeared to be well under way by 1979 in the Soviet Union. One of the methods, developed by Shevchenko, involved the use of di(2-ethylhexyl) phosphoric acid (DEHPA). The overall flowsheet was as follows:

- co-extraction of $\mathrm{Am}, \mathrm{Cm}, \mathrm{Sr}$, and rare eartns with DEHPA

- stripping of Sr with diluted nitric acid

- stripping of Am and Sr with lactic acid and sodium diethlyenetriamine pentacetate

- stripping of the rare earths with nitric acid.

It appears that this method was not suitable for partitioning HLLW, and the Soviets later developed a better method using tri-butyl phosphate (TBP). They have tested these methods at the Kholpin Radium Institute using HLLW from the reprocessing of WVER spent fuel. A processing rate of $5 \mathrm{l} / \mathrm{d}$ was accomplished using gravity-flow mixers-settlers with pulsed mixing and transfer of liquids. They have also studied actinide partitioning using phosphonates, phosphinates, phosphine oxides, arsine oxides, and amides of carboxylic acid (Galkin 1979).

The development of a process for processing HLLW to separate some of its constituents is considered to be one of the more urgent issues in fuel reprocessing and waste management (Afonin et al. 1988). Radioactive studies are being carried out on HLLW processing flowsheets to separate the waste into individual fractions of the fission products cesium, strontium, rare earths, and the transplutonium elements. It was stated that the separated fractions can be immobilized into monolithic glasses or ceramics or beads in a metal matrix [similar to the Belgian-German "Vitromet" process], thereby reducing the final volume for disposal significantly. 
One promising separation concept uses a solvent extraction system that has a polyhedral carborane complex of cobalt dicarbolyde (ChDC) in a mixture with a polar dituent such as nitrobenzene and polyethylene giycol. A pilot plant has demonstrated separation of about 300,000 curies each of cesium-137 and strontium-90 from severa? tens of cubic meters of acid HLLW, with decontamination factors of cesium and strontium from other elements of about 500 and strontium from cesium greater than 1000 (Aloy et a1. 1989). It also appears possible to separate the transplutonium and rare earth elements into individual fractions (Afonin et a?. 1988).

\subsection{HIGH-LEVEL LIQUID WASTE SOLIDIFICATION AND INTERIM STDRAGE}

Vitrification is considered to be the most promising method of conditioning $H\lfloor W$. The process has been comprehensively studied, resulting in the development of one-stage and two-stage versions of a "highly productive" process of vitrification (Semenov 1983).

Processes converting HLLW to a solid using a fluidized bed calciner, a spray calciner, a rotary evaporator, and ceramic and induction-heated batch and continuous melters have been studied. The Soviets appear to have decided on making phosphate and borosilicate glass-Tike HLW forms in a single-stage calcining-ceramic melter, crystalline HLW forms using a calciner and induction-heated melter, and the possible use of a microwave melting system (Kedrovsky et a1. 1987; Nikiforov et al. 1988). Following problems with a full: radioactive single-stage ceramic melter, the Soviets are developing a new wo-stage vitrification process (Cooley 1989). An overview of the major solidification systems is given in Figure 8.1 (Nikiforov et a 1.1988 ).

\subsubsection{Solidification Facilities and Systems}

\subsubsection{Description}

In 1989, it was reported that HLW solidification techniques were deve oped during the mid-1950s in the USSR. After 10 years of testing a vitr-fication unit capable of processing $1001 / \mathrm{h}$ of simulated HLW solutions [as well as experience with other test units], a fully radioactive facility [at kyshtym] with a HLLW processing capacity of $500 \mathrm{l} / \mathrm{h}$ [feed rate] was put in 


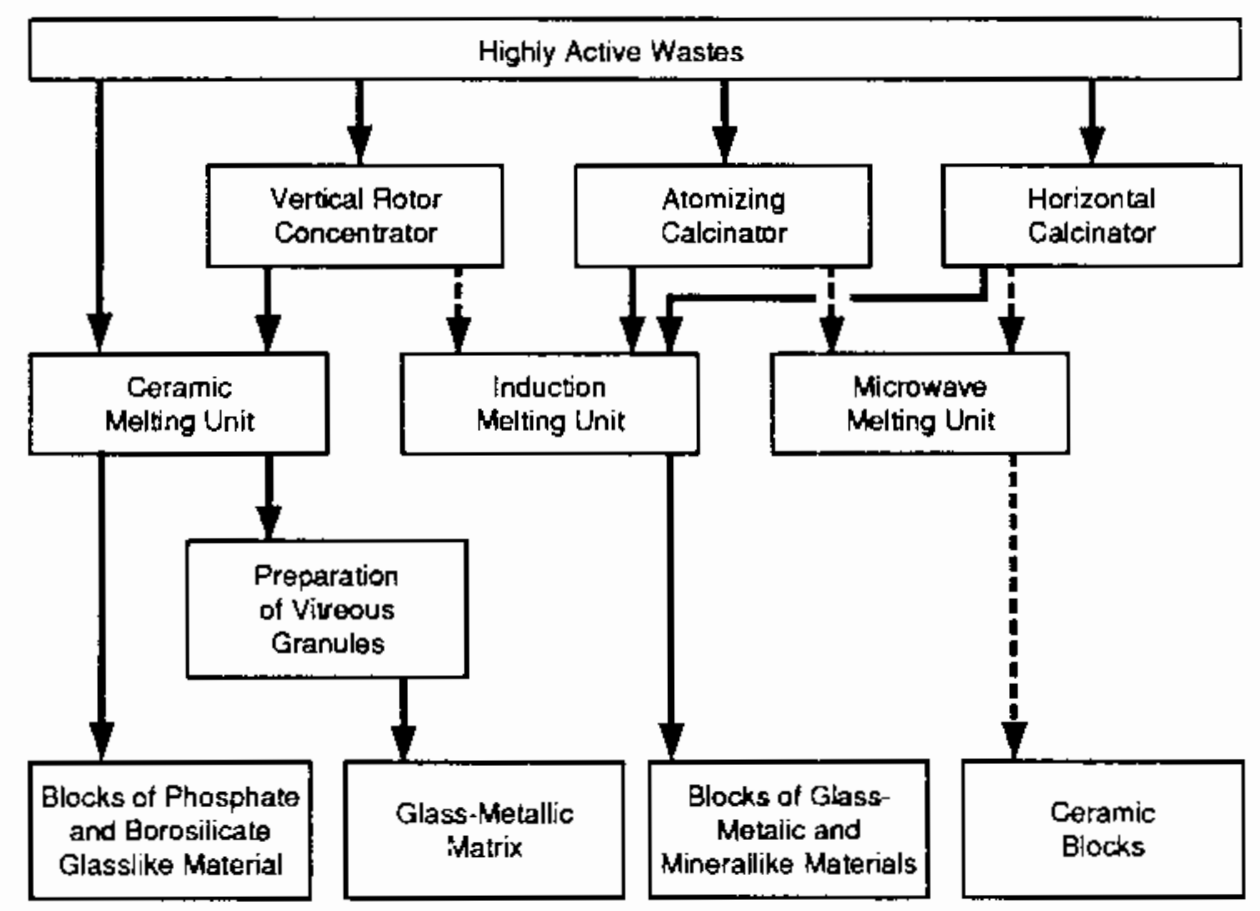

FIGURE 8.1. High-Level Liquid Waste Solidification Processes

operation during 1987. The phosphate glass is poured into mitd steel canisters, three of which are then placed in a container $0.63 \mathrm{~m}$ in diameter by $3.4 \mathrm{~m}$ in height (Drozhko et a1. 1989; 30-60 years, Sedov et al. 1988). The pour vessels (canisters) are sealed with welded lids (Cooley 1989). The lid of the larger container is welded on and then moved to a storage area for monitoring for two weeks. From there the containers are taken to a 1ong-term (20-30 years, Drozhko et a1. 1989) storage room (Chertkov 1989). These larger containers are stored onsite at the reprocessing plant using forced air cooling followed by passive air convection cooling (Cooley 1989).

The $5001 /$ h vitrification facility was shut down in 1988 (presumably due to glass melter electrode problems) after processing $1000 \mathrm{~m}^{3}$ of HLLW which was converted to $160 \mathrm{MT}$ of phosphate glass containing $3.9 \times 10^{6} \mathrm{Ci}$ (This corresponds to about 10 MT of PWR fuel of 33,00C MWd/MT burnup at 10 years age) (Drozhko et a). 1989). In a recent presentation, A. S. Nikiforov noted that $66 \mathrm{MC} i$ of waste had been vitrified, and glasses produced having 
activities up to $40 \mathrm{ci} / 1$. (a) A new vitrification facility is now under construction (Drozhko et a1. 1989), and expected to be started in 1990 using a melter of different design (Cooley 1989).

Apparentiy, as a result of the Soviets' unfavorable experience with the one-stage melter in their production facility, they are developing a twostage process that calcines the waste first in a rotary calciner (similar to the French AVM process). The pilot unit for this two-stage process is operating at the All-Union Research and Scientific Institute of Inorganic Materials in Moscow, with a capacity of $5-81 / \mathrm{h}$ of glass (Cooley 1989).

Recent information indicates that there may also be a solidification facility near Krasnoyarsk. According to E. I. Mikerin, the 1957 accident at Kyshtym forced the center's managers to begin removing the waste from storage tanks, and arrange for the wastes to be shipped to a special plant in the central Asian city of Krasnoyarsk, "where they are mixed with glass for longterm storage" (Washington Post 1989d).

\subsubsection{Solidified Waste and Containment Criteria and Characteristics}

High-level waste and waste packages for disposal must meet the following requirements:

- the wastes must be solid, they must meet specifications, and the composition must be well defined

- the solidified wastes must be durable and have long-lasting physical stability

- waste packages should allow for safe transportation and disposal operations

- waste package materials must not have future value

- the chemical composition of the wastes must prevent the formation of harmful chemical elements and must not allow for microbiological processes to occur when in the repository; the harmful characteristics or factors are:

(a) Presentation by Nikiforov at the 1989 Joint International Waste Management Conference October 22-28, 1989, Kyoto, Japan (based on notes taken by K.J. Schneider [PNL] who attended the conference). 
-radiolytically formed gases

- chemical reactions between the waste package and surrounding rocks

- combustible or explosive materials

-presence of moisture

- waste package properties must not induce changing rock characteristics and must not cause failure of sealing properties of the host rock (Kedrovskiy et al. 1989).

Phosphate glasses have received much attention, but studies have shown concerns over thermal stability and chemical durability. Geologic disposal of wastes with a thermal output of $10,000-40,000 \mathrm{~W} / \mathrm{m}^{3}$ are referred to, which require disposal in a geologic medium having a high thermal conductivity, such as granite, salt, and basalt. High-level waste glass blocks of less than $0.6 \mathrm{~m}$ in diameter are mentioned. Ceramic materials with a loading factor twice as high as glasses are also being considered as a waste form. References are made to glasses with a specific activity of $1,000 \mathrm{Ci} / 1$ (Kulichenko et al. 1979; Nikiforov et al. 1988).

\subsubsection{Research and Development}

The USSR has carried out significant R\&D on HLLW conditioning and vitrification since the mid-1950s. Incomplete information has been published in a number of places on parts of this work. As a result, this subsection is a compilation of known R\&D; a consistent chronology and progress of the work was not possible.

The most studied concept for solidification of HLLW is conversion to phosphate or borosilicate glass using a ceramic melter without pre-calcination. In addition, two-stage vitrification methods, with the first stage calcination process being performed with a "boiling-layer" [fluidized-bed calciner], a spray "atomizing" calciner, and horizontal and vertical rotating calciners have been studied. Induction-and microwave-heated melters are also being considered. Due to its sensitivity to waste composition, the "boilinglayer" calciner approach has been recently dropped (Sedov et al. 1988;

Nikiforov et al. 1988). Studies are under way to produce ceramic materials by the "widely used method of extrusion of puddled clay followed by dewatering and firing using a microwave generator" (Nikiforov et al. 1989). 
By 1976, the USSR had developed and tested vitrification equipment to include drying and calcining units, an induction-heated continuous melter, "single-use" crucibles, and a melting system based on a "chemothermic" reaction. References were made to R\&D on these processes dating from 1962. In addition, a single-stage [i.e., no liquid pretreatment such as calcination], two-zone ceramic melter, heated after startup by passing alternating current through opposing molybdenum electrodes, was developed and tested for two years as of 1976. Melter startup was achieved by filling the cavity with broken glass, and melting the glass [to achieve a conductive path for the molybdenum electrodes] using silicon carbide "Silit" heaters. The melter consisted of refractory materials, with adjacent water-cooled tubes to prevent loss of glass in the event of refractory damage and to decrease the refractory corrosion rate. The outer container for the melter was made of stainless steel. To reduce the entrainment of "solid components," molasses was added to the melter. Nitrogen oxides and other gases formed by decomposition of salts in the melter were treated by an off-gas system, which included a column containing pyrolusite $\left[M_{n} O_{2}\right]$ for trapping ruthenium (Konstantinovich et al. 1976). off-gases from the furnace were condensed, the condensate was fractionated, the subsequent gases were filtered through two aerosol filters, and lastly, nitrates were removed in an absorption column. Figure 8.2 shows a drawing of this ceramic melter (Kondratyev et a1. 1976; Nikiforov et a1. 1981b; McElroy 1989).

A feed rate of $100 \mathrm{l} / \mathrm{h}$ was used in this melter to solidify $1000 \mathrm{~m}^{3}$ of simulated HLLW, as well as solutions containing some selected radionuclides, into $100 \mathrm{~m}^{3}$ (250 MT) of phosphate glass in two years (Konstantinovich et al. 1976). The rectangular melter had an upper "curing" or "making" zone of $2.4 \mathrm{~m}$ in length, a "finishing" zone of $0.315 \mathrm{~m}$ in length, both having a width of $0.8 \mathrm{~m}$. The glass was poured from the melter through an overflow tube in batches of 200 liters into a receiving canister. The melter used 1800 amperes of electrical current at 160 volts in the larger "curing" zone. The leach rate of individual components of the glass was $10^{-6}-10^{-5} \mathrm{~g} / \mathrm{cm}^{2} / \mathrm{d}$ (Konstantinovich et al. 1976; Kondratyev et al. 1976; Nikiforov et al. 1981b). More recent information indicated that the melter processed $1116 \mathrm{~m}^{3}$ of synthetic and radionuclide-doped solutions with an output of $25 \mathrm{~kg} / \mathrm{h}$ of glass at a 


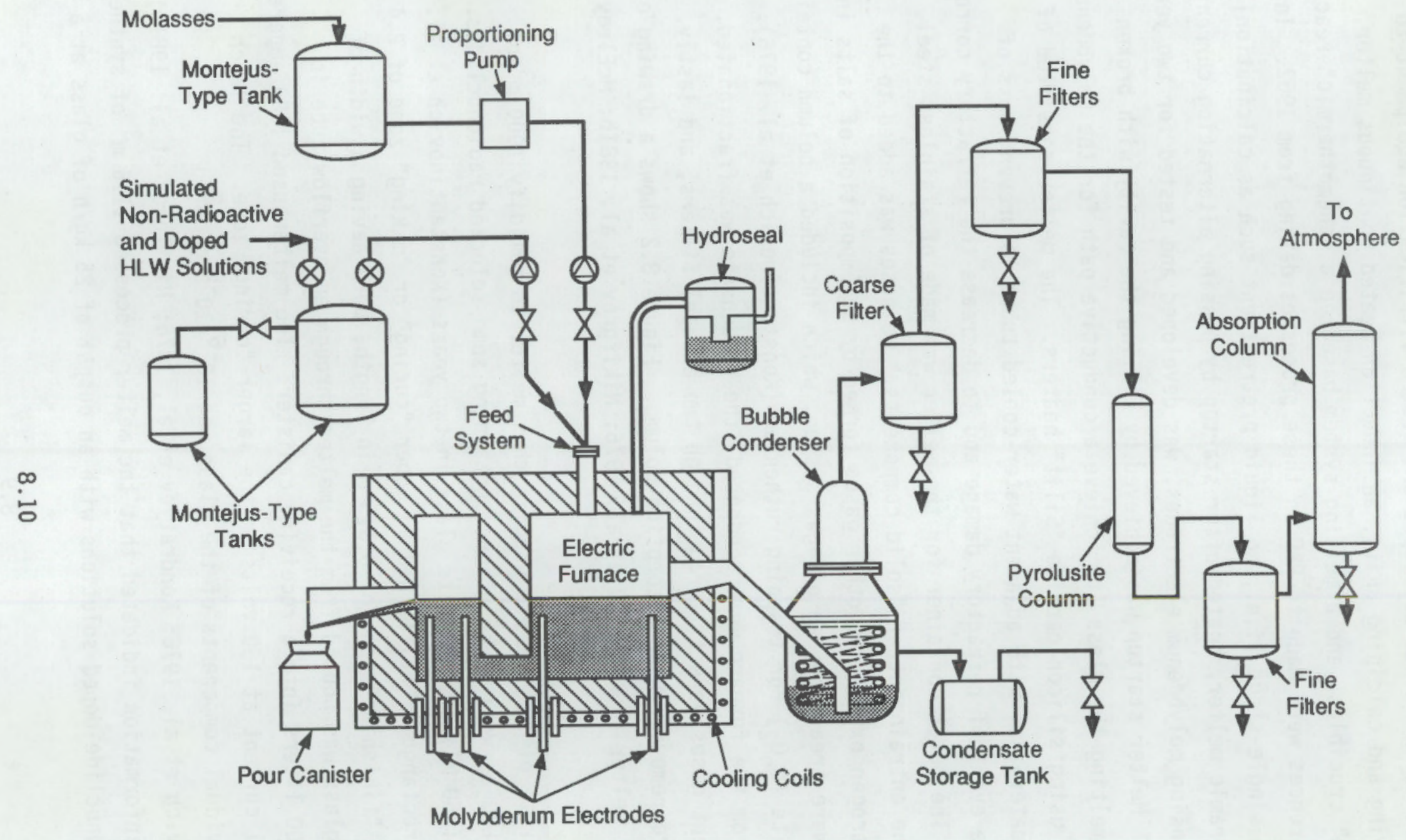

FIGURE 8.2. Diagram of HLW Ceramic Melter Vitrification Facility 
processing temperature of $950-1150^{\circ} \mathrm{C}$. A total of $134 \mathrm{~m}^{3}$ of phosphate glass was produced (McElroy 1989).

fis of 1979 , the USSR had another nonradioactive pilot vitrification plant (termed KS-KT-100) in operation for five years. The process used a fluidizedbed calciner and an induction-heated, batch melting ceramic crucible/container to make and store the phosphate glass. The process was for HLLW with high aluminum and sodium content. Molasses was added to the feed solution to the pre-evaporator/denitrator to reduce ruthenium volatilization. Batches of glass weighing $160-180 \mathrm{~kg}$ were produced in 8-10 hours at the rate of $20 \mathrm{l} / \mathrm{h}$, with a simulated HLLW feed rate of $1001 / \mathrm{h}$ (Davydov et al. 1976; Sombret 1979). It appears that the single-stage vitrification unit discussed previous ${ }^{-} y$ was developed in order to simplify the solidification process relative to the KS-KT-100 unit (Kondratyev et al. 1976). A scaled-up version of the KS-KT 100 has been developed and tested. At a calcination temperature of 350 $400^{\circ} \mathrm{C}$ and a fluidization rate of $1.5 \mathrm{~m} / \mathrm{s}$ the "output" of the facility was $100 \mathrm{l}, \mathrm{h}$ of initial solution, $65 \mathrm{l} / \mathrm{h}$ of evaporated solution, and $20 \mathrm{~kg} / \mathrm{h}$ of glass. A series of tests, lasting 1200 hours, has been carried out which showed the feasibility of this two-stage method of vitrification using phosphate glass. A total of $42.5 \mathrm{~m}^{3}$ of solution was processed and $5685 \mathrm{~kg}$ of glass were obtained in 39 crucibles (McElroy 1989).

Another two-stage process was being developed in 1979 for solidification of transuranic waste fractions from HLW. The transuranic solution concentrate was calcined in a horizontal rotary tube calciner, then made into a ceramic using pulped natural perlyte clay in "commercial equipment commonly used in the ceramic industry." Smail ceramic cylinders of 10-12 mm in diameter and height were made by drying, annealing and sintering in a resistance-heated electric furnace under about 400 atmospheres pressure and $1000-1300^{\circ} \mathrm{C}$. The ceramic contained $30-40 \%$ transuranic waste, and exhibited $25^{\circ} \mathrm{C}$ leach rates of $2-7 \times 10^{-6}$ for radiocesium and $1.5-5.5 \times 10^{-8} \mathrm{~g} / \mathrm{cm}^{2} / \mathrm{d}$ for americium (Aloy et al. 1988, 1989; Nikiforov et al. 1988).

In 1981, the Soviets were also considering producing HLW glass beads for incorporation into a matrix of metal or ceramic (Atomnaya Energia 1981). By 1984 , it was noted that techniques had been developed to incorporate waste 
into glass or crystalline materials and to embed solidified wastes into metal matrices. Blast furnace slags for use as a base material for producing pyroxene-7ike materials for embedding $H L W$ were being considered (Pushkov 1984). The Soviets noted that in $1979 \mathrm{~S}_{1} \mathrm{O}_{2}$ was added to blast furnace slags to produce pyroxenes, to which was added "wastes from reprocessing BN spent fuel." The mixture was melted at $1300-1350^{\circ} \mathrm{C}$ and produced a material of high strength and durability. Wastes from $B N$ spent fuel reprocessing were characterized by a high content of iron oxides $(20-25 \%)$, alkali metal oxides $(-20 \%)$, and rare-earth element oxides (-20\%) (INFCE WG 7 1979).

It appears that work on variations of the ceramic meiter process was continuing in 1981. Nikiforov notes that work was being carried out on converting HLLW to phosphate glass in the "first stage" and to borosilicate glass in the "second stage." For making phosphate glass, the simulated HLW concentrate contained $240 \mathrm{~g} / 1$ aluminum nitrate, $125 \mathrm{~g} / 1$ sodium nitrate, 120 $130 \mathrm{~g} / 1$ orthophosphoric acid, and $90-150 \mathrm{~g} / 1$ molasses. The simulated waste was fed to a fluidized-bed calciner operating at about $400^{\circ} \mathrm{C}$. The calcine was then melted (Nikiforov et al. 1981b).

A vitrification piant for HLLW from reprocessing $5 \mathrm{MT} / \mathrm{d}$ of VVER spent fue] was stated as requiring a HLLW feed rate of about $200 \mathrm{l} / \mathrm{h}$. [This indicates a HLLW volume of about 1000 1/MT of reprocessed spent fue1.] (Nikiforov et a]. 1981a).

Further information on ceramic melters, indicating their continuing development, was given in 1988 by Nikiforov. An experimental ceramic melter apparatus (this may be the same unit, or a modified version of the one discussed by Konstantinovich and Kondratyev in 1976 and Nikiforov in 1981) with a productivity of up to $100 \mathrm{l} / \mathrm{h}$ (feed rate) was reported to have been operating for ten years. The material chosen for the melting unit was a high-clay (alumina) zirconium refractory (called "Bakor"). Electrodes of molybdenum and various alloys have been tested as well as tin oxide. Phosphoric acid is used as the flux to obtain a glass-like phosphate material and the boron-containing mineral datolite is used to obtain a borosilicate material. At the same time, a reducing agent, molasses, is fed into the melting unit. It has been shown that the loss of ${ }^{106} \mathrm{Ru}$ from the melting unit is up to $5 \%$, that of ${ }^{137} \mathrm{Cs}$ is up 
to $0.6 \%$, and that of ${ }^{90} \mathrm{Sr}$ and rare-earth elements is $0.2-0.4 \%$. A foam layer forms when the solution reacts with molasses, which plays a significant role in reducing entrainment of radionuclides [particularly of ruthenium, as noted by cooley 1989]. The reaction occurs with the liberation of heat, which allows the specific energy consumption to be reduced from $1.7-1.9$ to $0.8-1.0$ per $\mathrm{kWh}$ per liter of HLLW processed. In laboratory conditions, it has been shown in "actual wastes" that the behavior of alpha-emitting radionuclides is analogous to the behavior of ${ }^{90} \mathrm{Sr}$. The presumed working 7 ife of the basic apparatus (melting unit) is up to three years (Nikiforov et al. 1988).

A radioactive bench-scale unit (called "Grom-1") was reported in 1988 to be operating to convert $5 \mathrm{l} / \mathrm{h}$ of radiocesium and radiostrontium concentrate fractions from HLLW into either monolithic glass or glass beads in a metallic matrix. The solidification system involves conventional evaporation and denitration, thin-film rotary evaporation, and melting in a ceramic crucible in a rasistance-heated furnace at $1000-1100^{\circ} \mathrm{C}$ for no more than three hours. Radiocasium is converted to a pollucite-like aluminophosphate glass (specific gravity $2.8-3.3 \mathrm{~g} / \mathrm{cm}^{3}$ ) with up to $30-50 \%$ of cesium oxide at $40-55 \mathrm{ci} / \mathrm{cm}^{3}$. Leaching of the glass is in the range of $2.5 \times 10^{-7}-6.5 \times 10^{-6} \mathrm{~g} / \mathrm{cm}^{2} / \mathrm{d}$. Radiostrontium is converted into a borosilicate glass (specific gravity 3.5 $3.7 \mathrm{~g} / \mathrm{sm}^{3}$ ) containing over $50 \%$ strontium oxide. "Vitromet"-type solids have been made by placing a basket of glass beads in a container of molten meta? and using a vacuum to pull the meit around the beads. Metal matrix materials used were commercial zinc, aluminum alloys, and lead. Also, ceramic waste forms shat showed very good leach rates were made using natural clays (i.e., perlyt3). Other characteristics are being evaluated (Aloy et a1. 1989, 1988). It was further noted that units had been developed which used synthetic HLW at a feed rate of $2 \mathrm{l} / \mathrm{h}$ to produce $5 \mathrm{~mm}$ glass granules for metal matrix waste forms which are intended for use on small volumes of high-activity wastes (Nikiforov et al. 1988).

I $\cdots$ was reported in 1989 that actual HLLW was being vitrified in a onestage melter. This radioactive unit had been operating for two years, and another test unit had been operating for six years (Cooley 1989). The fully radioactive one-stage melter that had been operating for two years was further 
discussed by Drozhko later in 1989. A radioactive facility [at kyshtym] with a HLLW processing capacity of $500 \mathrm{l} / \mathrm{h}$ was put in operation during 1987 . The melter was made of a high-alumina zirconium refractory, was heated using molybdenum electrodes, and used orthophosphoric acid as a fluxing agent with molasses added to reduce radionuclide entrainment to the off-gas system. The phosphate glass is poured into canisters, three of which are placed in a container $0.63 \mathrm{~m}$ in diameter by $3.4 \mathrm{~m}$ in height. The pour vessels (canisters) each contain 200 liters of HLW glass (Drozhko et a1. 1989) and are sealed with welded lids (Cooley 1989). The HLW vitrification facility was shut down in 1988 (due to glass melter electrode problems) after processing $1000 \mathrm{~m}^{3}$ of liquid HLW, which was converted to 160 MT of phosphate glass containing $3.9 x$ $10^{6} \mathrm{Ci}$ [This corresponds to about $10 \mathrm{MT}$ of PWR fuel of 33,000 MWd/MT burnup at 10 years age] (Drozhko et al. 1989). More specific data indicates that $998 \mathrm{~m}^{3}$ of HLW containing $3.87 \mathrm{MCi}$ were vitrified into $162 \mathrm{MT}$ of phosphate glass which was contained in 366 canisters yielding 122 containers. Further details of the fully radioactive meiter, as well as canisters and containers, are as follows (McElroy 1989):

\section{MELTER DATA}

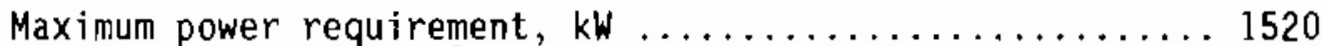

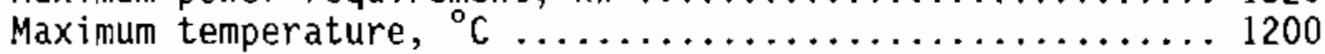

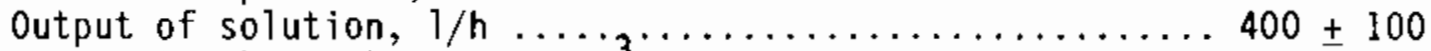

Single batch of glass melt, $\mathrm{m}^{3} \ldots \ldots \ldots \ldots \ldots \ldots \ldots \ldots \ldots .2$

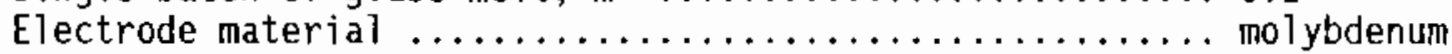

Specific electricity copsumption, $\mathrm{kW} \times \mathrm{h} / 1 \ldots \ldots \ldots \ldots 2.0$

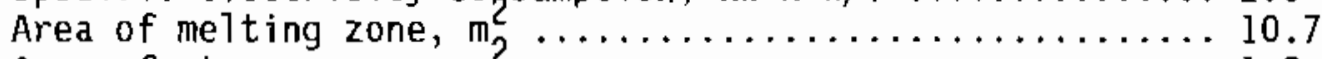

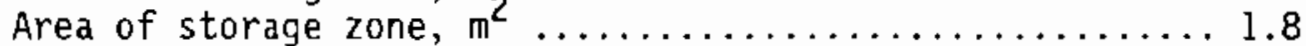

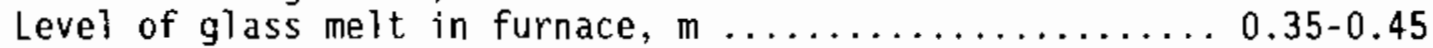

Outside dimensions of furnace, $\operatorname{mrn} \ldots \ldots \ldots \ldots \ldots \ldots \ldots \ldots . \ldots \ldots 480 \times 4200 \times 3200$

Number of electrodes ....................... 56 (4 groups of 14)

\section{CANISTER DATA}

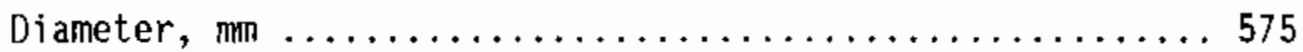

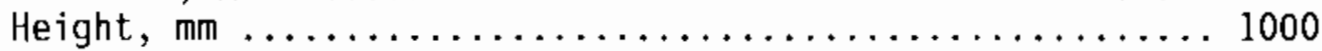

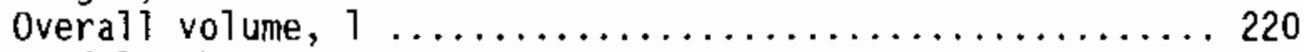

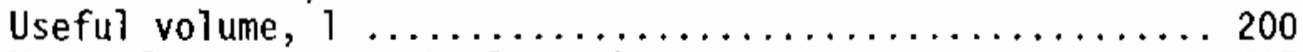

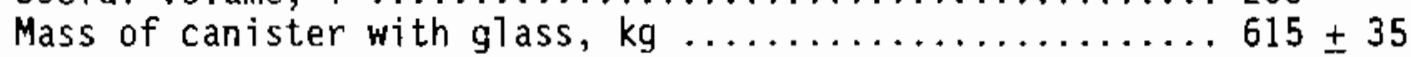

Canister material ................................. Carbon steel 


\section{CONTAINER DATA}

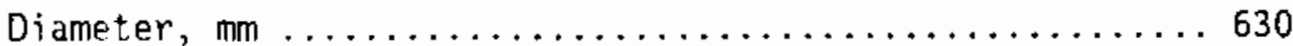

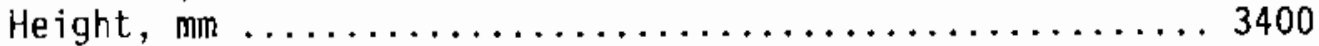

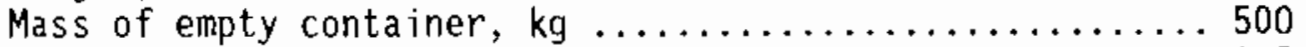

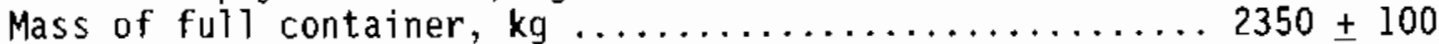

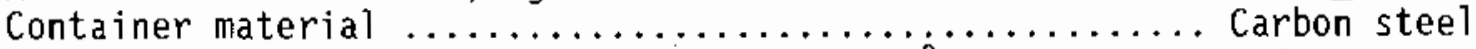

Permissible temperature of container walls, ${ }^{\circ} \mathrm{C} \ldots \ldots \ldots 200$

Evidently, considerable difficulty has been encountered with the fully radicactive meiter. The water-cooled molybdenum electrodes in the melter have corroded and other problems have arisen that were not described (Cooley 1989). It was further stated that the melter shutdown was due to a "faiture of the system for water cooling the power leads supplying the furnace electrodes" (McElroy 1989). The Soviets also acknowledged difficulty with noble metal precipitation in their production HLW melter, but claimed that they knew how to solve it and had the problem solved. One solution mentioned was to remove the noble metals before the vitrification step. They also claimed that they use multiple feed ports as a method to gain better chemical reactions and mixing in the melter but it is not clear that this was the "solution" to the noble netals problem. The HLW melter is designed to process either phosphate glass or borosilicate glass (note that this approach was mentioned by Nikiforov in 1981). A moderately low operating temperature of $900^{\circ} \mathrm{C}$ is used when processing the phosphate glass. The glass components are added as a solid naterial when processing borosilicate glass and as a liquid when processing phosphate glass. Apparently, denitration is not used prior to feeding the waste to the melter (Cooley 1989).

A new HLW vitrification facility is now under construction that will vitrif, ILW and HLW combined waste streams. The ILW streams are intended to play a role in a fluxing agent (Drozhko et al. 1989). Another melter of a different design is expected to be started in 1990 (Cooley 1989).

The Soviets are now developing a two-stage process that calcines the waste rirst in a rotary calciner (similar to the French AVM process). The pilot unit for this two-stage process is operating at the All-Union Research and Scientific Institute of Inorganic Materials in Moscow with a capacity of 5-8 $1 / h$ of glass (Cooley 1989). Research and development is being carried out 
there as well to develop longer-lasting electrodes in joule-heated melters for incorporating $\mathrm{HLW}$ into phosphate and borosilicate glass. The normal molybdenum electrodes corrode at a relatively rapid rate in the radioactive pilot plant at the All Union Scientific Research Institute. The high corrosion rates occur largely because of the sulphur and iron content $(1.2$ and $10.0 \mathrm{wt} \%$, respectively) of the glasses. Test electrodes with tin oxide or metallic chromium-based alloys offer improved corrosion resistance at the temperatures of 1100-1150 ${ }^{\circ} \mathrm{C}$ encountered (Polyakov et al. 1989).

Continued work on refractories, electrodes, and electrode lead materials for ceramic melters was reported in 1990. Various combinations were tested to determine optimum material combinations at operating temperatures. Refractories included zirconium and aluminum oxides (known as Bakor 33 and 41 ) and chromium and aluminum oxides (known as XAU-30), molybdenum and tin dioxide were tested as electrodes, and Monel metal $(70 \% \mathrm{Ni}, 30 \% \mathrm{Cu})$ and a nickelbased alloy $(70 \% \mathrm{Ni}, 15-17 \% \mathrm{Cr}, 13-15 \% \mathrm{Ti})$ were tested as uncooled, electrica] connector lead materials for the electrodes. The nickel alloy was chosen as the best lead material. The XAU-30 brick was the most corrosion resistant in the glass melts but, probably due to their higher electrical conductivity, these refractories showed the highest corrosion at the interface between the electrode and the refractory. It was stated that further R\&D would be needed on electrodes and refractories (Borisov et al. 1990).

Research and development activities were reported to be under way in 1989 on making HLW ceramic (mineral-like) materials using a two-stage process involving a water-cooled metal crucible with high-frequency heating ( 1.76 megahertz at $160 \mathrm{~kW}$ power) which produces temperatures of $1200-1700^{\circ} \mathrm{C}$. The development work shows that "crystal glass" and mineral-like materials of pyroxene, pyrosilicate, titanate, titanium silicates and garnet types can be produced that incorporated $15-25 \%$ fission product oxides, which have a density of up to $3.7 \mathrm{~g} / \mathrm{cm}^{3}$, and a radionuclide leaching rate $2-3$ orders of magnitude lower than borosilicate glasses. The process is continuous, and to reduce the entrainment of radionuclides in gases, a layer of calcine and flux is always available at the molten material surface (Nikiforov et al. 1989). Interest in 
this type of solidification process is also evidenced by recent Soviet discussions in the Australian Synroc process (Nuclear Waste News 11/89).

Aralys is of this work showed that the development of a small-size "cold crucib:e" made of stainless steel, and remotely replaceable, could be an effect-ve process for melting the waste. An important factor was the short period of time a molten mass remains in the melter (up to 30 minutes at $1500^{\circ} \mathrm{C}$, which practically excludes its separation even at a high content of platinum and transplutonium elements. However, a melter of this type can be only used if the solution is pre-calcined or dried and this complicates significantly the instrumentation of the process as compared with the process using a ceramic melter (Nikiforov et a1. 1989).

In a recent presentation, A. S. Nikiforov noted that $66 \mathrm{MCi}$ of waste had been vitrified, and glasses produced having activities up to $40 \mathrm{Ci} / 1$. (a) Tests have also been performed on HLLW and plutonium and americium concentrates from WVER and $B N$ reactor fuel reprocessing which showed that alphaemitters did not form volatile compounds and additional gas-cleanup units were not required (Nikiforov et a1. 1989).

The Soviets are also studying transmutation as part of their HLW management strategy. Calculations have been made showing the "nearly complete" transfurmation of strontium-90 and cesium-137 into short-lived isotopes in a neutron flux of $10^{18} \mathrm{n} / \mathrm{cm}^{2}$-s for 10 hours. It was stated that "One fusion reactor is quite enough for the transmutation of cesium and strontium obtained from tie operation of more than 100 WVE-1000 reactors" (Nikiforov et a). 1989).

\subsubsection{Solidified High-Level Waste Storage Facilities and Systems}

Interim storage of solidified $\mathrm{HLW}$ and ILW is considered necessary to reduce the heat generating rate before disposal. Also, storage is planned until the safety of ultimate disposal is proven and a disposal facility is operating (Sedov et al. 1988; Kedrovskiy et al. 1989).

(a) Presentation by Nikiforov at the 1989 Joint International Waste Management Conference 0ctober 22-28, 1989, Kyoto, Japan (based on notes taken by $K$. J. Schneider [PNL] who attended the conference). 
In the early $1980 \mathrm{~s}$ it was stated that the time of residence of solidified wastes in an interim subsurface storage facility depends on their initial heat release. Wastes with a high heat release require a six-year retention. As the heat rate of the solidified waste declines due to aging, the storage "pit" can be transformed into a "burial facility," chamber by chamber, but the capability for removing and loading the waste canisters in shipping casks for transfer to the deep geological repository will be maintained (Nikiforov et a1. 1981b; Sedov et a1. 1983; Semenov 1983).

More recent information indicates that the containers with three canisters of vitrified $H L W$ from their production facility are stored onsite at the reprocessing plant (Kyshtym) using forced air cooling followed by passive air convection cooling. It is planned to store the solidified HLW until the heat release is reduced from radjoactive decay by a factor of up to 10 before disposal (Cooley 1989), which has been stated as between 20-60 years (Sedov et a1. 1988; Drozhko et a1. 1989). Nikiforov recently indicated that vitrified wastes are kept in an air-cooled storage facility "adjacent to the ceramic melter building" (Nikiforov et a1. 1989).

According to E. I. Mikerin, the HLW tank accident at Kyshtym in 1957 caused the removal of the waste from storage tanks for shipment to a special plant in the central Asian city of Krasnoyarsk, "where they are mixed with glass for long-term storage" (Washington Post 1989d).

\subsubsection{Description}

As of 1981, designs were being developed for interim storage of vitrified HLW with the following characteristics:

- The facility was to have the storage capacity for five years' production of glass.

- The facility was to be at ground level above the water table.

- The facility was to be adjacent to the waste vitrification plant and connected to it with a structural transport corridor.

- Containers with vitrified waste were to be emplaced using a remotecontrolled crane with a capacity of 5 MT.

- The storage vault was to be lined with stainless steel. 
- T'e vitrified waste containers were to be readily retrievable (Kondratyev et a1. 1979; Nikiforov et al. 1981a).

\subsubsection{Research and Development}

In 1978, conceptual designs and cost analyses had been developed for three types of facilities for interim storage of vitrified HLW with heat generation rates of $10^{4}-10^{5} \mathrm{~W} / \mathrm{m}^{3}$. In the first concept, air cooling of stacked canisters would be carried out in individual tubes with air flowing directly past the canisters; in the second concept, air cooling of stacked canisters would be done in individual tubes with air flowing outside of the protective storage tubes; in the last concept, water cooling would be used for canisters stacked within tubes in a water basin. Air cooling is stated as being the most economical for heat generation rates up to about $5 \times 10^{4} \mathrm{~W} / \mathrm{m}^{3}$. For heat generation rates above $10^{5} \mathrm{~W} / \mathrm{m}^{3}$, water cooling is required (GKAE 1978 , p. 35).

\subsection{COST INFORMATION}

A 1978 estimate for a facility for solidification of HLLW from reprocessing $5 \mathrm{MT} / \mathrm{d}$ of WVER fuel indicated that the capital cost would be 15.1 million rubles and the operating costs would be 2 million rubles/year. The plant would process $1500 \mathrm{~m}^{3} / \mathrm{yr}$ of 1 iquid wastes. Operating costs for storage of HLLW as liquids in tanks were indicated to be about $12 \%$ higher than operating costs for vitrification, and capital costs were about 2.2-fold higher than those for vitrification. It was cautioned, however, that the vitrification costs were based on early data and analys is (GKAE 1978, p. 63). The cost of vitrifying HLLW is about $12 \%$ lower than that of storing it in tanks. The capital costs for vitrifying a unit volume of HLLW are a factor of 2.2 lower than for storing it. Storing HLLW requires replacement of the storage tanks every 20-25 years (Nikiforov 1981a). The distribution of costs for HLW management, exclusive of waste disposal, were given in 1983 as follows: receiving, neutralization and storage, 25-35\%; solidification, 40-60\%; interim storage of solidified HLW, 10-15\% (Sedov et al. 1983). The costs of solidification of HLLW have been more recently stated to be $40-60 \%$ of the cost of treatment, solidification, and subsequent interim storage of HLW, with the 
capital costs for these three stages (excluding geologic disposal), amounting to $2-3 \%$ of the total capital costs of the entire nuclear fuel cycle (Nikiforov et al. 1988).

\subsection{ACCIDENT IN THE URALS, 1957}

\subsubsection{Summary}

Numerous articles have appeared over the last 30 years about a "nuclear accident in the Urals or at Kyshtym in the USSR." The articles draw inferences about what occurred in the accident based on pieces of information gained by interviewing emigrants and defectors, and reviewing various bits of medical and ecological evidence. Based on the information in the open literature, a rather unclear picture was pieced together about the accident. The fact that an "accident" occurred with large releases of radionuclides to the environment was clear. However, what the accident was and what caused it, the time and area over which it occurred, the amounts of radionuclides released, and the number of resulting fatalities was not. In the Summer of 1989, the Soviets acknowledged that the accident had occurred in September 1957 at Kyshtym, and that it was caused by an explosion, initiated by a chemical reaction of nitrate and acetate salts, in a high-level radioactive waste tank. The accident (later revealed to be on September 29, 1957 at 4:20 p.m.) was said to have released $2 \times 10^{6}$ Curies ( $4 \%$ of that supposedly released by the Chernobyl Unit $\# 4$ accident), contaminated an area of 375 square miles, and caused the evacuation of over 10,000 people.

\subsubsection{Background and History}

The accident was first publicly mentioned in a vague, 1958 Copenhagen newspaper account, which alleged it was a factor in the Soviet decision to suspend nuclear tests unilateraliy in March of that year (Washington Post 1989b) .

The newspaper Die Presse Vienna, Austria, had a short story in its issue of March 18, 1959, stating that a nuclear physicist from a Soviet satellite country had heard from a Soviet physician, a member of the Academy of Medicine, that "a catastrophic accident" at a "large atomic experimental 
station" (atomic weapons facility) had caused "172 cases of serious atomic burns" and "more that 20 cases of injury to the eyes ... northwest of Sverdluvsk". The first significant indication of the kyshtym accident that was available in the open literature in the West was the publication of the articl 3 by the Soviet dissident, Zhores Medvedev, in the English journal New Scientist of November 4, 1976, entitied "Two Decades of Dissidence". The Medvedev articie was not about the accident, but about the dissident scientists within the Soviet Union (Parker 1983).

Medvedev's initial claims were subsequently confirmed by Lev Tumerman, formerly head of the biophysics laboratory at the Institute of Molecular Biology in Moscow who emigrated to Israel in 1972. Tumerman told Medvedev that he had personally seen large areas of land in the region that had been permanently evacuated, with many villages and towns destroyed (News and Comment 6/89).

Shortly after the articles were published, Medvedev gave a seminar at 0ak Ridge and at Los ATamos on this "radioactive waste disposal accident". The U.S. scientific community then started to investigate his allegations and check $h$ is references. It found that the references, as cited, did exist and established fairly clearly that there was a large contaminated area in the Soviet Ural mountains area that had been evacuated. As indicated in the first scientific critique of Medvedev's work, there was disagreement about the size of the area that was contaminated and the degree of contamination. There was al so cisagreement about the cause of the accident (Parker 1983).

A detailed assessment of the accident was published by Trabalka et al. in 1979 after reviewing the Soviet radioecology literature. According to this report, (which was in turn reported in the New Scientist) one of the clues to the accident was the modification of the water drainage system of the Techa river in the region involved. Two large reservoirs with a total surface area of sore $50 \mathrm{~km}^{2}$ have been built on the Techa river immediately downstream of Lake kyzyltash, in an area abundant in lakes. An associated canal system now brings water, that would normally have been drained into Lake Kyzyltash, round the lake and the two man-made reservoirs to a point well downstream on the Techa river. 
The authors of the report found another clue in the fishing stock records of the USSR, which showed that all the lakes enclosed within the affected area have never been stocked while those around it have. Finally, the pinpointed area contains three lakes of $4.5,11$ and $20 \mathrm{~km}^{2}$. respectively; lakes of these sizes persistently crop up in Soviet radioecological studies of the area. Trabalka et al. offered a possible explanation for the accident as the "detonation of a large volume of dried high-level wastes containing significant quantities of ammonium nitrate, following failure of a cooling system on a high-level waste storage tank." (Trabalka et al. 1979; New Scientist $1 / 10 / 80)$.

Another detailed reference on this issue was published by Parker in 1983. After a rather exhaustive literature search, Parker drew the following conclusions: At present, the best supposition is that there were many releases of radioactive wastes to the river system over time, plus an explosion in the fuel reprocessing plant, and that would help to explain the widespread distribution of radionuclides. The small amount of short-7ived nuclides relative to long-lived ones can also be explained by the releases over an extended period and the time between the accident and the beginning of these studies (Parker 1983).

A total of 11 classified documents of the U.S.'s Central Intelligence Agency (CIA) were petitioned by a consumer action group and were released in November 1977. These were reviewed by Parker, as well as a news clipping from the Christian Science Monitor and two Foreign Broadcast Information Service items of November 11, 1976. In addition, there are another 15 documents which were not released because of the highly classified nature of the material.

The first of the eleven documents indicates that "in the winter of 1957. an unspecified accident occurred at the Kasli atomic plant". The second document contained "miscellaneous information on nuclear installations in the USSR", saying "in Spring $1958 \ldots$ he heard ... that large areas north of Chelyabinsk were contaminated by radioactive waste from a nuclear plant ..." "As early as 1954 the water of the Techa River, running from Lake Kyzyltash and Lake Ulagash and emptying into the Inset River at Dalmatovo, had become highly radioactive." It also indicated that "in March, 1958, an explosion 
wrecked part of the nuclear plant at Kyshtym. Whether the explosion was nuciear or chemical, the source could not tell." The third document says, "no nuclear waste burial site ... was identified within the ... areas." The fourth document indicates "the occurrence of an accidental atomic explosion in the Chelyabinsk 0blast during the Spring of 1958 was widely known throughout the USSR. Rumors are that many people were killed; however, the generally accepted version is that on $7 y$ several score (individuals) died ..." The fifth document indicates, "on an unknown date prior to June 1959, an accident occurred in the CheTyabinsk Oblast which caused radioactive contamination of the soil." The sixth documents states, "in early May, 1961, a terrific explosion occurred somewhere in the Chelyabinsk 0blast." It said, "the explosion was so terrific that the ground and buildings shook." The seventh document discusses "a mysterious explosion in the Chelyabinsk 0blast in Aprit 1960 (with) possible radioactive fallout causing destruction of trees and vegetation, and many people burned as a result of the explosion. The hospital (at Chelycbinsk) was completely filled with victims of the explosion." The eighth document says that about 1956 "there was a nuclear explosion near Chelyabinsk," and that it "was a production site for nuclear devices." "The chief evidence of the explosion was the tremendous number of casualties in the hospitals of Chelyabinsk." The ninth document says that it was a "Soviet detonition of a 20 megaton device in the 1950s in an above-ground test," and occurred in the 1957-1958 period. The tenth document says that the "1958 Kyshtym disaster" was a "nuclear accident involving plutonium waste from military nuclear reactors." The eleventh and final report, no date, states, "In the Spring of 1958 hundreds of persons were exposed to radiation and injured as a result of an explosion at the Kyshtym plant." "In early October 1959, an atomic test reportedly took place in kyshtym." The dates and causes of the accidents in the CIA documents are so widely divergent that it would be impossible to pinpoint more than the fact that there was an accident, a large area was contaminated by radioactive materials, and the approximate location and $t$ me of the accident (Parker 1983). 


\subsubsection{Accident Cause and Waste Management Activities}

In December 1988, Y. P. Velikhov, Vice President of the Soviet Academy of Sciences, broke the silence on the nuclear accident at a military complex in the Soviet Urals in 1957-1958 and stated that an accident had occurred. [The accident was believed to have involved $H L W$ or separated fractions from $H L W$. Velikhov stated that he would try to find out what happened. In addition, a Swedish researcher, C. Larsson, made public that satellite photographs showed that the accident may have been worse than the 1986 Chernobyl accident (Kyodo $12 / 88)$.

In June 1989, it was acknowledged that a nuclear waste explosion in 1957 forced the evacuation of more than 10,000 people and left hundreds of square miles of territory uninhabitable for many years. At a news conference in Chelyabinsk, details were given of the disaster, 60 miles from the accident site in the Ural Mountains. Boris Nikipelov, the first deputy minister for machine-building, said that a container holding radioactive waste from a nuclear weapons factory exploded in september 1957, Tass reported. It left a trail of contamination about six miles wide anc 65 miles long, Nikipelov said. He said, according to Tass, that there were "no casualties" (Washington Post 1989b). But dissident Soviet biologist Zhores Medvedev estimates that hundreds may have died from the radiation effects. He says that the accident disseminated a larger quantity of the long-term radioactive substance Strontium-90 than Chernobyi, prompting him to term the 1957 incident the worst nuclear accident in history (Washington Post $1989 \mathrm{~d}$ ).

The radioactivity released [ejected into the atmosphere] totaled 2 million curies, or 25 times less than the release in the Apri\} 1986 accident at the nuclear power plant in Chernobyl in the Ukraine, according to the report. Boris Nikipelov said that officials hope to take advantage of the presence in the area of specialists in radiation and nuclear power for continuing research and monitoring of the disaster site (Washingtor Post 1989b). More than 30 years later, large areas around the town of Kasli, 60 miles north of the city of Chelyabinsk, are still contaminated and water reserves are undrinkable. A cleanup campaign costing about $\$ 300$ million was carried out to try to eliminate the consequences of the accident, and by 1978, economic activity had 
been restored in about 80 percent of the contaminated zone. The accident was never reported [because] it occurred at a defense factory (Whashington Post 1989a).

Later, in June 1989, it was stated that the site for construction of the South Urals nuclear reactors [near the Kyshtym site] was not selected by chance. Since 1957, certain reservoirs here have been quite polluted. By taking sut water from them and evaporating it, the power piant will clean them up. Apart from that, there are good specialists in the region who are capable of ensuring the efficient work of the station (Moscow Domestic Service 1989).

Additional information on the accident at Kyshtym was made avajlable in the press in July 1989. Soviet officials who were present at the time of the accident revealed that a grievous set of technical misjudgments and poor work habits caused the explosion of a large vat of wastes from the production of plutoniam (Washington Post 1989d).

The evacuation eliminated many small villages and towns from the map and forced the Moscow Institute for Bio-Physics to establish a local branch to keep track of all the persons exposed. Tons of soil were moved and buried, roughly 70 square miles were declared unfit for human use, and a special researc: center was created to monitor the health of the nearby residents. The government is preparing to release the health records and hold the first public hearing on the accident before a special commission of the new Soviet legisla:ure, the Congress of People's Deputies (Washington Post 1989d).

Evgeny I. Mikerin, a director of the main department of manufacturing and technology for the State Committee for the Utilization of Atomic Energy was, at the time of the accident, manager of a plant on the grounds of the complex that produced plutonium by reprocessing spent nuclear reactor fuel. He said the radioactive wastes from its operations were dumped into a series of stainless steel and concrete tanks located slightly more than a mile away from plant. Mikerin said to keep the wastes at the Kyshtym site from becoming explosive due to a natural chemical reaction, they were cooled by a coil of water tubing along the interior wall of each tank. The designers of the tanks did not provide a mechanism for repairing the tubes in the event they fajled, he addec. Sometime in 1956, the tubing in one of the tanks began to leak and 
[the flow of water to the tank] was then shut off. During this period, the wastes began to dry, Mikerin said, presumably from chemically induced heat, and highly explosive nitrate salts and acetate collected at the surface. By chance, Mikerin said, "a control device in the tank produced a spark," which detonated the salts, and the resulting explosion obliterated the tank and all that it contained (Washington Post 1989d).

More details were made available at a special afternoon session at the International Symposium on Recovery Operations in the Event of a Nuclear Power Plant Accident, organized by the International Atomic Energy Agency and held November 6-10, 1989, in Vienna. The Soviets indicated that the tank that exploded was one of 16 [stainless] steel tanks with a capacity of about $300 \mathrm{mi}^{3}$ each [given as $250 \mathrm{~m}^{3}$ in Nuclear News 1/90a] that were used for the storage of high-level wastes from reprocessing (Nuclear News 1/90b). The tanks were installed in a concrete-7ined trench and each tank had individual water jackets for cooling. The concrete cover over the trench was $250 \mathrm{~cm}$ thick (Nuclear News 1/90a).

The contents of the tank (about 70-80 MT of liquid containing around $20 \mathrm{MCi}$ of waste), became overheated and largely evaporated (after the coolant was shut off due to a pipe leak) leaving explosive residues of sodium nitrate and acetate salts. These residues reached a terperature of $350^{\circ} \mathrm{C}$ (given as $500^{\circ} \mathrm{C}$ in Nuclear News 1/90a) and, at 4:20 p.m. on September 29 , exploded, with an estimated force equivalent to 70-100 tonnes of TNT (tri-nitro toluene). [Note: It was a7so stated that based on the distances that pieces of the concrete cover were thrown, the Soviets estimated that the blast was equivalent to the detonation of 8-10 tonnes of TNT (Nuclear News 1/90a).] The blast killed two guards (Nuclear News 1/90a; Lehman 1989), and two adjacent tanks were also damaged (Nuclear News 1/90b).

Most of the $20 \mathrm{MCi}$ was deposited in the immediate vicinity of the tank, but an estimated $2 \mathrm{MCi}$ was ejected up to $1000 \mathrm{~m}$ into the atmosphere. An important factor is that this waste had been treated for removal of cesium and iodine. The composition of the $2 \mathrm{MCi}$ of released radioactivity was given as: $\mathrm{Ce}^{144}\left[+\mathrm{Pr}^{144}\right](66 \%), \mathrm{Zr}^{95}+\mathrm{Nb}^{95}(24.9 \%), \mathrm{Sr}^{90}+\mathrm{Y}^{90}(5.4 \%), \mathrm{Ru}^{106}+\mathrm{Rh}^{106}$ (3.7\%), Cs $^{137}(0.036 \%)$ (Drozhko et al. 1989). 
It. was reported that the feared redistribution and migration of deposited radioactivity over a wider area did, in fact, result in only a small increase in the area of the "footprint" [compared with that of the original explosion], even though much of the radioactivity was in a soluble form. Within the first 7-10 diys after the accident, about 600 people were evacuated from nearby settlements, where maximum areal concentrations of strontium-90 were in the range of $10-100 \mathrm{ci} / \mathrm{km}^{2}$. Over the following 18 months, further evacuations were cerried out, eventually totaling 10,180 people (Nuclear News 1/90b). The evacuation zone is reported to have been based on an activity level of two curies per square kilometer and resulted in 23 small viliages being evacuated. The Soviets have indicated that the pine forests suffered the most environmental damage; about one third [of the pine forests] died from the contamination (Lehman 1989).

Initial population doses were estimated from skin conditions, blood pressures, and stomach problems. Keriotyping of blood samples was done 5-6 weeks after the accident to estimate doses and urinalysis was the primary method used to estimate internal contamination. In the first three years after the accident, 3000-5000 people were analyzed. During the next 27 years, determinations were made that people received 50-80 rads to the bone structure, 30 rads to the bone marrow and 17 rads whole-body maximum dose. From 1500-3000 people were reported as still being monitored (Lehman 1989). Some of the results of extensive health studies carried out among the evacuated populations showed that no statistically significant differences have been observed for any of the groups, including a group of 1054 people who received a dose of $530 \mathrm{mSV}$ [53 rem, a substantial dose]. Only in the blood cancers is there a slight indication of increase with radiation exposure (Nuclear News $1 / 90 b)$.

Several officials cited the $1957 \mathrm{Fall}$ season's cool weather, which caused most windows to be shut, as a saving grace. Nevertheless, workers ended up not only excavating and burying topsoil, but also replacing the roofs of some buildings and washing exterior walls with a mixture of water and sand. Mikerin said the "agricultural district," which is largely populated by Tatars heavily dependent on the local land and water, bore the brunt of the disaster. 
Although the reprocessing plant was "the most contaminated of all our facilities," work there was so important it was halted for only a month, he said (Washington Post 1989d).

Asked how the accident affected him, Alexei E. Spirin, director of Kyshtym's first plutonium production reactor, said he has noticed some "abnormally big plants" in the area during hunting expeditions. He added that he stopped eating wild berries and mushrooms for roughily a decade after the accident. Mikerin said the accident forced the center's managers to begin removing the waste from storage tanks, and arrange for the wastes to be shipped to a special plant in the central Asian city of Krasnoyarsk, where they are "mixed with glass" for "long-term storage" (Washington Post 1989d).

It should be noted that there were contaminated areas at Kyshtym prior to the 1957 accident. Yevgeny Velikhov, a vice president of the Soviet Academy of Sciences, helped arrange an unprecedented two-day visit to Kyshtym in July 1989 by a group of U.S. Congressmen and representatives of an environmental group, the Natural Resources Defense Council (NRDC) (Washington Post 1989d). A report, prepared by NRDC staff based on their discussions and observations, indicates that "from 1948 to sometime in the late $1950 \mathrm{~s} \mathrm{HLW}$ containing an estimated 120 million curies of 30-year half-life strontium 90 and cesium-137 was discharged directiy into a small lake" [Lake Karachai]. The lake is now slowly being entombed in concrete to prevent the dispersion of radioactivity. It was stated that the dose rate for a trip to visit the lake would have resulted in an exposure of about 500 millirems per person. At an unspecified date the mode of waste management was shifted to storage in double-walled stainless tanks. Leaks in these storage tanks have occurred once or twice; the inventory in these leaky tanks was then shifted and the tanks were repaired (NRDC 1989). It has also been reported that "unti1 1951, nuclear waste was dumped into the river Techa," and 8000 people had to be resettled as a result (Moscow Domestic Service 1989). Contanination was discovered as far away as the Arctic Ocean (KOMSOMOL SKAYA PRAVDA 1989).

Decontamination work is still going on at the site of the 1957 accident at Kyshtym in the Urals, said Lev Ryabev, Deputy Chairman of the USSR Council of Ministers, in the fall of 1989 . He said that the main concern was Lake 
Karacrai, a lake within the Kyshtym military area (NEI 10/89, p. 11). Drozhko noted that the lake had an area prior to the waste discharge of $0.26 \mathrm{~km}^{2}$ and a volunite of $143,500 \mathrm{~m}^{3}$ of water. About $95 \%$ of the radioactivity is sorbed in "the ceposits of the lake" (Drozhko et al. 1989). The lake was used as a dump for 1 iquid radioactive wastes until concrete reservoirs were built later, and the plan now is to "bury" it, according to Ryabev. The work is expected to take around four years and would cost 60 million rubles. Speaking about decontamination of the land surrounding the Kyshtym site, Ryabev said that on $1 y 160 \mathrm{~km}^{2}$ still remain to be dealt with. This would be decontaminated at a rate of around $20-30 \mathrm{~km}^{2}$ per year so the cleanup would be complete in 5-7 years. Biologist Zhores Medvedev, former dissident and author of a book about the disaster (Nuclear Catastrophe in the Urals), returned to the USSR to testify before a commission looking into what happened. An international meeting on the accident, along the 1 ines of the IAEA Chernobyl post-accident meeting, is under discussion (NEI 10/89, p. 11).

For more detailed information on the 1957 accident at Kyshtym, the reader is referred to recent articles by Buldakov et al. 1989; Nikipelov 1989;

Romanov et al. 1989; and Ternovskij et al. 1989. 



\subsection{LOW-LEVEL AND INTERMEDIATE-LEVEL WASTE CONDITIONING AND STORAGE}

Soviet practices regarding conditioning and storage of all wastes other than high-level wastes are discussed in this section. These wastes are low-level and intermediate-level wastes.

\subsection{SUMMARY}

In the Soviet Union, liquid low-level and intermediate-level waste streams from reactor operations are first reduced in volume, and then solidified ssing bitumen or concrete. A bituminization facility is operating at the Lelingrad RBMK reactor site, and another is being built at the Ignalina RBMK raactor site. Vitrification may be used in the future for intermediatelevel waste concentrates. In the past, millions of curies contained in millions of cubic meters of liquid were disposed of by well injection into underground areas contained by "watertight rock strata." Some gaseous wastes were disposed of by injection as well. This practice is now not considered to be "absolutely reliable" and thus is unlikely to be used in the future. Rather, it appears that solidified liquid wastes--along with solid wastes--are disposed of in shallow-land burial sites located at most large power reactor stations, with final disposal possibly in geologic formations. Research on tritium-bearing and other gaseous wastes is mentioned, as well as a waste minimization program aimed at reducing waste streams by $30 \%$. Transuranic wastes are not discussed or defined as a separate category of wastes, as in the United States. This category of wastes is [presumed by the authors to be] included in intermediate-level wastes. In addition, the Soviets acknowledge 35 regional disposal sites for industrial wastes; no information is available on conditioning or storage of these wastes.

\subsection{POLICY AND STRATEGY}

As of 1970 in the Soviet Union, a system of centralized collection and burial of wastes from small producers (scientific-research institutes, medica) institutions and other organizations that use radioactive isotopes) at various burial sites was used. This system had been built in all large centers to 
reduce the possibility of spreading radioactivity from decentralized sources of wastes (Spitsyn et al. 1970a).

Interim storage of solidified $I L W$ for tens of years before disposal is currentiy envisioned. The main reasons for the long-term interim storage are to reduce the heat before disposal and to prove the safety of the disposal concept (i.e., the same as for HLW) (Sedov et al. 1988). Interim storage in surface or shallow-1and burial structures is permitted pending final disposal in geologic formations. These interim storage structures are equipped with a drain system, "clay shields," and concrete ceilings (Nikiforov et al. 1989).

Solid low-level waste processing and disposal will become much more important once large-scale decommissioning of Soviet reactors has begun. The USSR is assessing the low-level waste problems associated with reactor decommissioning. Reactor vessels will likely not be removed in one piece.

Decontamination and cutting into scrap will be difficult work and will produce much low-level waste. Decommissioning wastes may be placed in interim storage, but the definitive scheme has not yet been adopted. There are technical and economic incentives to age the wastes and mothball decommissioned nuclear plants for a period of time to let decay take its course before dismantling the reactors. "If you cover a site with concrete right away, radioactivity will still get out" (Nucleonics Week 5/88).

Treatment methods for radioactive wastes are selected based on the physical/chemical properties, radioactivity level, and characteristics of the radioactive materials in the wastes. The key goal in treating 1ow-level and intermediate-level wastes is to reduce the volume of wastes to be disposed (Sedov et al. 1988).

\subsection{LOW-LEVEL AND INTERMEDIATE-LEVEL WASTE QUANTITIES}

A WER-1000 currently produces from $10,000-15,000 \mathrm{~m}^{3}$ of 1 iquid radioactive wastes each year. The evaporation of the wastes results in about 50 MT of salts. The RBMK reactor plants produce about $10,000 \mathrm{~m}^{3}$ of liquid wastes each year, resulting in about 100 MT of evaporated salts. The new RBMK reactors being developed will produce about 50\% more wastes than the units now in service because of increased complexity of piping (Nucleonics Week 5/88). 
Solid active wastes are generated by Soviet power reactors at the rate of 200 $400 \mathrm{~m}^{3}$ /GWe-yr (Nikiforov et al. 1989).

The major constituents in low-level liquid wastes arising from WVER and RBMK reactor operations are the nitrate, oxalate and phosphate salts of sodium. Wastes from WVER reactors also have a significant borate content (Sapovilikov 1988).

The quantities of iquid high-level, intermediate-level, and low-level wastes generated at fuel reprocessing plants were given as $0.7-1.0,3-5$, and 50-100 $\mathrm{m}^{3} / \mathrm{MTU}$, respectively (GKAE 1978).

\subsection{LOW-LEVEL WASTE TREATMENT AND STORAGE}

At a 1970 symposium in France, the Soviets presented a large number of detailed papers on low-level and intermediate-level waste management which were compiled by the U.S. Department of Commerce. These papers included data, operating experience, costs and flowsheets on their efforts up to 1970 (DOC 1970). [Because of the old age of these papers, they are not discussed in this study.]

Low- and intermediate-level liquid wastes from Soviet nuclear power stations were defined in 1981 as those with an activity no greater than $10^{-4}$ $\mathrm{Ci} / \mathrm{liter}$. [The value, however, was given as $10^{-5} \mathrm{Ci} / \mathrm{liter}$ in the $1983 \mathrm{ref}$ erence for Tables 1.1 and 1.2 in Section 1.2.] These wastes include regenerating solutions from ion exchangers, solutions from decontamination of equipment, hardware and clothing, leaks of contaminated liquids, and pulps of perlyte and ion exchange resins (Nikiforov et al. 1981a).

A national program is under way to reduce low-level liquid waste volumes by $30 \%$ at Soviet nuclear plant sites. This will be done by more precise methods of sampling from the primary circuit, organizational methods, and recycling of soluble salts (Nucleonics Week $5 / 88$ ).

The concentration of ILLW and LLLW with a salt content of less than $\mathrm{lg} / \mathrm{l}$ is apparently carried out by ion exchange, coagulation, or membrane technology, depending on the amount and characteristics of the waste. A major goal is to reduce the volumes of ILW and LLW for disposal. To accomplish 
this, combustible wastes are burned, and the ashes are solidified together with ILLW concentrates. Some solid ILW is mechanically compacted (Sedov et a1. 1988).

\subsubsection{Treatment Facilities and Systems}

The largest amounts of solid radioactive wastes arising from Soviet reactor operation and fuel reprocessing are in the low-and intermediate-level categories. The final forms of these wastes are loaded into steel drums (Sedov et a 7. 1983). Dry wastes at reactors are reportedly not much of a problem for treatment (Nucleonics Week 5/88). Low- and intermediate-level liquid wastes from nuclear power plants are concentrated by evaporation and processed through ion exchange. The water is reused because environmental release is forbidden. The resulting $200-300 \mathrm{~g} / 1$ of salt content is incorporated in bitumen or cement (Cooley 1989).

As of 1970, the chief methods of reducing the volumes of solid LLW were incineration and compaction. At that time, the central radiation safety sta. tion (TSSRB) was conducting laboratory-and pilot-scale operations on the adoption of these technologies (Sobolev et al. 1970). Also in 1970, it was a universally accepted practice to immediately process all liquid radioactive waste at nuclear power stations using evaporation and ion-exchange methods. The concentrated wastes were collected and piped to special storage reservoirs for moderately radioactive wastes. The amounts of concentrated liquid radioactive wastes from nuclear power stations were about $1 \mathrm{~m}^{3} / \mathrm{yr} / \mathrm{MW}$ of electrical capacity. The specific radioactivity of concentrated liquid waste in storage reservoirs was in the range of $10^{-4}-10^{-2} \mathrm{Ci} / 1$ (Gusev et a]. 1977).

As of 1977, solid wastes were not incinerated at Soviet nuclear power stations, although at the Zagorsk central waste disposal station, an eiectrical furnace was successfully used to incinerate wastes. The regulations allow the incineration of waste materials at nuclear power stations, but only if the requirement for prevention of atmospheric contamination by radioactive substances is met (Gusev et a1. 1977).

As is done with ILW, combustible LLW is burned, and the ashes are combined with other LLW for final solidification in bitumen or with ILW liquid 
concentrates. Use of bitumen for containing waste constituents in the range of 30-50 wt\% has been demonstrated. Metallic LIW may be separated for decontamination, remelting and reuse (Sedov et aj. 1988).

Low-level liquid wastes, with a salt content of less than about $1 \mathrm{~g} / \mathrm{liter}$ and whose composition is relatively constant, can be treated by chemical, mechanical, and ion exchange techniques. These wastes are typically concentrated by evaporation, and the concentrates are solidified for ultimate disposil. The concentrates and residues are then combined with intermediatelevel wastes. Bituminization, cementing, incorporation in polymers, and vitrification (intermediate-leve? wastes) are being considered for final waste forms. The treated water is reused in the facility processes (Sedov et al. 1983, :98B).

A universally applicable method for clean-up of homogeneous low-level liquid wastes has been developed using a two-stage ion-exchange process. The ion-exchange resins are regenerated and used repeatedly, and the solutions are evaporated. After hardening, the residues are sent to storage, while the water can be recycled. The final volume of wastes to be stored is only $0.2 \%$ of the initial volume (Semenov 1983).

Treatment of radioactive gaseous streams involves use of special filters and recovery of specific gaseous radionuclides. Glass fiber and synthetic fiber filters are used (Sedov et al. 1988).

\section{c.4.1.1 Description}

As of 1970, a central "decontamination station" for treating low-7evel liquid wastes was set up near Moscow for servicing wastes from nearby scientific and research facilities. The facility treated wastes by coagulation with settling and filtration and by two-stage ion exchange treatment. The regenerating solutions were evaporated, with the residues undergoing additional concentration (Kondratyev et a1. 1970). Spitsyn al so noted that the primary methods of decontamination of liquid waste streams were by coagulation, ion exchange, evaporation and electrodialysis. The Soviets were also investigating oil flotation and mineral sorbent decontamination methods. A pilot electrodialysis plant for the two-stage decontamination of waste 
solutions, with a capacity of $100 \mathrm{~m}^{3} / \mathrm{d}$, was tested in 1970 at the Moscow Decontamination Station (Spitsyn et a). 1970a).

As of 1981, homogeneous low-level 1iquid radioactive wastes from USSR nuclear power stations were processed by collection, mixing, and neutralization in tanks. After removal of the coarser suspended matter and adjustment of the pH to about 11, the mixture was evaporated (typically in one to three parallel units) until salts were saturated at $300 \mathrm{~g} / 1$, and then put into concrete tanks lined with stainless steel. Heterogeneous liquid wastes were passed directly into the concentrate storage tanks, awaiting final conditioning (Nikiforov et a1. 1981a).

The Radon Radioactive Waste Facility near Moscow has a compactor to reduce the [solid] waste volumes nearly 10 -fold. It also has an incinerator (with an extensive off-gas cleaning system that includes dozens of filters) for burning combustible wastes, with a volume-reduction factor of 20-100. Liquid wastes are solidified by bituminization. A disposal facility is also located onsite ( $B B C 3 / 28 / 86$ ). Another decontamination station is located in the outskirts of the city of Lvov, in the Bryukhovichi forest. It contains a special laundry facility used by institutes, clinics and hospitals. It also handled clothing from those involved in the Chernobyl accident. Wastes are reported to be stored in concrete vessels with concrete poured on top (Moscow TRUD 1989).

The first commercial bituminization facility using a thin-film evaporator has been operated at the Leningrad nuclear power station since 1984, according to Sapovnikov (1988). [Note that this date is 1986 according to Nikiforov et al. 1989]. It was planned to use rotary bituminization devices with a water evaporization capability of 200 or $500 \mathrm{l} / \mathrm{h}$ at nuclear power stations (Sapovnikov 1988).

Several storage compartments of $3000 \mathrm{~m}^{3}$ each were constructed for storage of bituminized wastes. At present, the compartments contain concentrated 1iquid bottoms with a concentration of 210-290 $\mathrm{g} / 1$ of solutes and a specific activity of $10^{-5}-10^{-7}$ Bequerels/l (Nikiforov et a]. 1986). Additional facilities are being operated, and others are being installed at other nuclear power stations (Sapovnikov 1988). Nikiforov indicates that the bituminization 
facility at Leningrad started operation in 1986 and a similar unit is being introduced at the Ignalina reactor site (Nikiforov et al. 1989).

A typical bituminization facility for LLLW at a nuclear power plant includes prior concentration in a continuous thin-film evaporator/bituminizer operating at $150-160^{\circ} \mathrm{C}$. The optimum capacity of a unit is $200 \mathrm{l} / \mathrm{h}$ of evaporated water. The bituminized waste from the bottom of this equipment is screw-fed into 200-1iter drums. This final waste product contains about $50 \%$ waste solids and reduces the volume of waste to be buried by a factor of 1.5 1.7 (Sapovnikov 1988).

The Soviets are attempting to develop a single-stage liquid waste evaporation process to replace the multi-stage process now being used at reactor plants. Research on evaporation, however, has been plagued by foaming due to surfactants in the liquid waste. They are "attempting to cure the problem by evaporating wastes in an alkali environment." Earlier experiments with charcoal filtration of trapwater wastes were not suitably effective (Nucleonics Week 5/88).

Radioactive gas streams from nuclear power plants are filtered with highefficiency filters made of synthetic fibers for ventilation systems or glass fibers for process systems. Activated charcoal filters are used to trap iodine. Some installations use chromatographic adsorption on charcoal for trapping short-ijved noble gases and for holding them to allow decay before discharge. Other installations use gas hold-up vessels upstream of the charcoal adsorber (Sedov et a1. 1988).

\subsubsection{Solid Low-Level Waste and Package Characteristics}

Evaporated liquid low-level wastes are incorporated into cement and bitumen. These materials cannot contain more than $50 \%$ salts. At a level above $50 \%$ salts, there is a loss of water resistance and an increase in product viscosity. Ash from some incinerated wastes is also immobilized in this way (Nucleonics Week 5/88). These solidified low-level and intermediatelevel wastes are placed in steel drums (Sedov et al. 1983). 
The leach rates from bituminized low-level reactor wastes with $50 \%$ waste loading are reported as $10^{-3}-10^{-5} \mathrm{~g} / \mathrm{sq} \mathrm{cm} / \mathrm{d}$. Irradiation to 100,000 rems does not significantly alter the leach rates (Sapovnikov 1988).

\subsubsection{Low-Level Waste Treatment Research and Development}

The basic research in $10 \mathrm{w}$ - and intermediate-level waste management was being conducted in 1970 at the Institute of Atomic Energy (I. V. Kurchatov) and its Moscow decontamination station, Moskovskaya Stantsiya Ochistki (MSO), the Institute of Physical Chemistry USSR Academy of Sciences (IFKhAN), the Central Radiation Safety Station (TSSRB), and the Scientific-Research Institute of Atomic Reactors (NIIAR) (Spitsyn et al. 1970a).

In the early 1980s, two types of solidification processes were under development in the Soviet Union for liquid wastes from nuclear power stations. These were 1) thermal processes using bitumen and/or wastes from the chemica? and petrochemical industries, and 2) urea-formaldehyde resins, roomtemperature cementation, and incorporation into thermosetting resins. However, bituminization had been developed the most extensively and was recommended for use at operating and planned nuclear power stations (Nikiforov et al. 1981a).

In 1983, studies were under way in the Soviet Union to develop processes and equipment for reducing the solid waste volumes by burning the combustible wastes to ashes (with volume-reduction factors of 10-100) followed by solidification, and compacting other wastes (with volume-reduction factors of 2-10) (Sedov et a]. 1983).

Experimental work on treatment of gaseous radioactive wastes includes filtration with glass fibers and woven synthetic absorption fibers. Radioiodine is trapped on activated carbon. The resultant gas/vapor streams undergo purification by distillation, with water and caustic scrubbing. Tritium is removed with condensates. Krypton removal by low-temperature adsorption on activated carbon, by absorption in freon, and by cryogenic distillation are all undergoing experimental verification (Sedov et al. 1988).

As of 1978, R\&D was conducted on managing tritium-bearing wastes (from reprocessing) by voloxidation, recycling of fiquids, and underground injection 
of the 1 iquid wastes. Processes considered for krypton-85 management after removal from reprocessing plant off-gas streams included underground injection of the gas, storage in pressurized tanks, and conversion to clathrates followed by storage (GKAE 1978, p. 19, 52). Nikiforov indicates that a "radiochromatographic gas cleanup system is designed to trap radionuclides from reactor operations which incorporates hydrogen removal and burning, moisture removal, aerosol filtration, and adsorption of krypton, xenon, and iodine" (Nikiforov et al. 1989).

Research and development has been carried out on removing the organic content of liquid radioactive wastes by magnetic separation and by ozonizatior. If an organic tends to cause foaming, an auxiliary ferromagnetic substance in powder form is added, and the foam is separated magnetically. For non-emulsifying organic materials, ozonization can be used to destroy the organ c component (Aloy et al. 1989).

\subsubsection{Cost Information}

As of 1970, the Soviets found the ion exchange method to be more economica than evaporation for treatment of LLLW when the salinity does not exceed $1 \mathrm{~g} /$ /iter (Kondratyev et a1. 1970). The cost of incorporating 1 iquid low-livel and intermediate-level radioactive wastes into bitumen plus interim storacle was $25 \%$ lower than for storage of these wastes in stainless stee? tanks (GKAE 1978, p. 11).

"he Soviets consider extended storage of LLLW and ILLW after concentration t.o be unnecessary and expensive. Thus, only minimum lag storage is to be provicled for these wastes before final solidification (Sedov et al. 1988). The distribution of costs for $10 \mathrm{w}$ - and intermediate-level waste management, exclusive of waste disposal, were given in 1983 as follows: receiving, neutralization and storage, $5-10 \%$; solidification, $70-80 \%$; interim storage of solidified wastes, $10-15 \%$ (Sedov et al. 1983). 


\subsection{INTERMEDIATE-LEVEL WASTE IREATMENT AND STDRAGE}

\subsubsection{Treatment Facilities and Systems}

For solidification of intermediate-level liquid waste concentrates, bituminization, cementation, inclusion in polymers, and vitrification may be used by the Soviets. Ashes from incineration of ILW and some LLW are combined with the ILW Tiquid concentrates (Sedov et al. 1988).

The Soviets intend to condition some alpha-containing wastes by vitrification (Nuclear Europe 1-2/88), as well as ILW concentrates (Nikiforov et a]. 1989).

\subsubsection{Description}

As of 1983, the processes and equipment for the bituminization of intermediate-level wastes were the most developed of the waste conditioning processes in the Soviet Union. Bituminization was stated to allow for the solidification of nearly all intermediate-level liquid wastes and sludges from nuclear power stations and radiochemical facilities (Sedov et a1. 1983).

Concentration of ILLW with a salt content of more than $1 \mathrm{~g} / 1$ is carried out by evaporation. The concentration of ILLW and LLLW with a salt content of less than $1 \mathrm{~g} / 1$ may be carried out by ion exchange, coagulation, or membrane technology, depending on the amount and characteristics of the waste. A major goal is to reduce the volumes of ILW and LLW for disposal. To do this, combustible wastes are burned, and the ashes are solidified together with ILLW concentrates. Some solid ILWs are mechanically compacted (Sedov et al. 1988).

\subsubsection{Research and Development}

Soviet research and development on ILW treatment has included evaporation and incorporation in bitumen, cement, polymers and glasses. Tests were done on storage of bitumen blocks in clay soils (Semenov 1983). In 1983, studies were also under way to develop processes and equipment for reducing the solid waste volumes by burning the combustible wastes to ashes (with volumereduction factors of 10-100) followed by solidification, and by compacting other solid wastes (with volume-reduction factors of 2-10) (Sedov et al. 1983). 
Conditioning of nuclear power plant ILW concentrates that contain boron by vitrification into a phosphate glass was studied on simulated and actual waste solutions from 1980 to at least 1984 by the Soviets. It was concluded that the process would be acceptable. The final product had a specific gravity of 2.0-2.4 and exhibited a water leach rate of $10^{-4}-10^{-6} \mathrm{~g} / \mathrm{sq} \mathrm{cm} / \mathrm{d}$ (Minaev et a 1. 1985). The corrosion resistance of various materials was studied for melte construction for boron-aluminum phosphate glass melts (Brazhneva et a1. 1985; Minaev et a1. 1985).

Vitrification of ILW has been studied using materials as fluxes, such as "datolite" with silicon dioxide, loam soils, and boron anhydride. The volumes of thase final waste forms would be 3.7-fold less than for bituminization and 10-fold lower than for cementation, and they would have lower leach rates (Pushkov 1984). It was recently reported that it is "planned to vitrify the major volume of ILW concentrates with a borosilicate flux using ceramic melter equipment similar to that designed for high-level waste" (Nikiforov et al. 1989)

investigations are under way for incorporating transuranic wastes in ceram ic materials (Nuclear Europe 1-2/88).

\subsubsection{Cost Information}

IIS of 1978, the cost of incorporating liquid low-level and intermediatelevel radioactive wastes into bitumen plus interim storage was $25 \% 10$ wer than for storage of these liquid wastes in stainless steel tanks (GKAE 1978, p. $11 ;$.

\subsubsection{Storage Facilities and Systems}

As of 1983, intermediate-level liquid wastes were stored for short time periods in stainless steel tanks (without cooling systems). For more reliable and cost-effective storage, the Soviets have developed bituminization (Semenov 1983).

Solidified intermediate-level wastes can be stored in above-ground storage facilities located near the solidification facilities. For nuclear district heating stations that are located near inhabited areas, solidified 
wastes are to be shipped in containers to storage cells, to await future shipment off-site (Sedov et al. 1983). 


\subsection{WASTE DISPOSAL SYSTEMS}

This section presents information on Soviet waste disposal activities for high-level, low-level and intermediate-level wastes. Disposal concepts as well as criteria are included.

\subsection{SUMMARY}

The USSR has a number of regional low-level waste (LLW) burial facilities to min mize the distances of radioactive waste shipments and to reduce transportat on-related risks. Some LLW [and presumably, intermediate-level wastes] may be buried in disposal facilities within the originating nuclear reactor plant loundaries if geologic conditions are favorable. Otherwise, disposal must be done in central or regional disposal facilities (Nucleonics Week 5/88). Gaseous wastes are presumed to be either vented or trapped, with the solids disposed of as with other solid LLW or ILW. Some gaseous wastes have been disposed of by well-injection.

Sc 1idified ILW may be disposed of in the future with HLW if economical, or in special repositories near the land surface. Recent information describes a burial site near Krasnoyarsk for "CMEA reactor wastes" in tunnels underneath and/or on the other side of the Yenisey River from existing military facilities (KOMSOMOLSKAYA PRAVDA 1989; Nuclear Waste News 7/89a). Krasnoyarsk has also been mentioned as the location of a special plant where wastes from Kyshtym storage tanks [presumed to be HLLW] are sent and are "mixed with giass for long-term storage" (Washington Post 1989d).

In addition to the wastes from reactor operations disposed of at reactor sites, the Soviets claim as many as 35 regional sites for the disposal of industrial, medical, and research radioactive wastes.

Geologic disposal of vitrified HLW has been studied over the last decade by the Soviets. Disposal concepts under serious consideration include mining shafts, deep drill holes, and underground excavations. The Soviets plan to make use of man-made barriers and waste packages in permanent disposal, but the geologic formation will be relied upon as the primary protective barrier. Althougn criteria for waste packages have been developed, they are still very 
general. The construction schedule for a repository is unclear: a reference claims that it will be "addressed" in 5 -10 years (Nucleonics Week 5/88). Recentiy, the chairman of the GKAE indicated that a decision on the first site may be made in one year, and that one candidate site is in Chelyabinsk (Nucleonics Week 10/89a). A recent report indicates that the Soviets are also looking at space disposal and transmutation of cesium and strontium (Nikiforov et al. 1989).

\subsection{POLICY AND STRATEGY}

\subsubsection{High-Level Waste Disposal Systems}

The overail requirement for disposing of HLW in the Soviet Union is to protect man and his environment from the harmful effects of radiation. A final repository system must meet acceptable requirements related to the geological enviroment, construction and technology, quality and characteristics, geography, safety, economics, and legality (Kedrovskiy et a1. 1989). The Soviets recentiy indicated that they are studying the possibility of space disposa1, pointing to the "experience in the U.S.A. on using ${ }^{238} \mathrm{Pu}$ as a heat source for electricity in satellites." They appear to be focusing on space disposal of ${ }^{129} \mathrm{I},{ }^{238} \mathrm{Pu}$, and "others" (Nikiforov et a1. 1989).

The USSR does not yet have a repository for its HLW, or an official program, but it is working on site selection with the Khiopin Radium Institute in Leningrad doing extensive site-screening work (Lehman 1989). As of 1987 , the Soviet Union was emphasizing work on salt and granite as potentiai host rocks for a deep geological repository, and they were in a site-screening stage in which a number of sites were being considered (Saltzman 1987).

Site investigations for a deep geological repository consist of genera! survey work on salt, granite, clay, gneiss, and other formations. After exploration is completed, the Soviets will select a site for more detailed investigations. The basis for site selection may be based primarily on economics and minimizing transportation by rail. They have already experienced some pressure from the "Greens" concerning their site studies (Cooley 1989). Another source indicates that the main siting areas are the lowlands surrounding the Caspian Sea in salt domes and bedded salt, and a Cambrian clay near 
Leningrad. Granite was considered unfavorable due to "circulating water probiems." It was noted again that the Soviets believed the greatest risk was from transportation (Lehman 1989). It has been stated that there are no plans for disposing of HLW in Latvia (Semenov 1989).

A. Protsenko, Chairman of the State Committee for the Utilization of Atomic Energy (GKAE), recentiy stated that the USSR is now looking for candidate sites for a HLW repository. One candidate site, he confirmed, is in Chelyabinsk [Kyshtym], the site of the 1957 explosion that left large 1 and areas unusable for decades (see Section 8.7). He said the USSR may make a decision on its first site for HLW disposal "next year" (Nucleonics Week $10 / 89 a)$.

As reported by Kondratyev in 1976, studies with low- and intermediatelevel waste disposal by well injection led to the conclusion that, after cooling, HLLW could be treated similariy. It was further stated that (Kondratyev et a 1. 1976):

"A level of radioactive fission products in the rock that would not heat the solutions above their boiling point under the pressure in tie collector pit must be insured when highily active wastes are b.uried underground. Studies by Soviet scientists have demonstrated that these conditions can be achieved by first storing the solutions for 10-20 years and treating the collector pit rock with nitric acid o. surfactants."

Whethe well injection of HLLW was actually performed is not known.

10.2.2 Low-Level and_Intermediate-Level Waste Disposal Systems

Between 1963 and 1976, the Soviets disposed of tens of mi7lions of curies of fission products as ILW in underground storage "reservoir beds," also called "collector pits." [This is believed to involve deep-well injection.] (Kondratyer et al. 1976).

A: of 1978 , the strategy for disposal of LLW and ILLW at reactor stations with appropriate geological and hydrogeological conditions was to inject the neutra or slightly alkaline wastes into deep wells onsite. The deep wells were required to be located in slow-moving aquifers bounded by aquitards (GKAE 1978 , F. 9). Some gaseous wastes were also disposed of by injection (New Scientist $4 / 21 / 77)$. 
As of 1981, it was planned to construct permanent repositories for at-reactor-generated LLW within the nuclear power station sites (Nikiforov et a]. 1981a). Solidified ILW may be disposed of with HLW if economical, or in special repositories near the land surface (Sedov et al. 1988). This may be the case with a site near Krasnoyarsk underneath and/or near the Yenisey River where "reactor wastes" may be being disposed of, and wastes from storage tanks at Kyshtym "are mixed with glass for long-term storage" (KOMSOMOLSKAYA PRAVDA 1989; Washington Post 1989d; Nuclear Waste News 7/89a).

Solid LLW and ILW waste forms [such as bitumen and concrete from reactor operations wastes] are disposed of in shallow-level repositories. Solid wastes such as decommissioned equipment, debris, filters, special clothes, etc., are disposed of in shallow-level repositories equipped with a drain system, clay shields, and concrete ceilings (Nikiforov et al. 1989).

\subsection{HIGH-LEVEL WASTE DISPOSAL SYSTEMS}

\subsubsection{Site Selection}

According to Kedrovskiy et al. (1989), the overall criteria for selection of the region for a geological waste repository in the Soviet Union are:

- Waste disposal should preferably be carried out in a location near its place of generation to eliminate the necessity of transportation over long distances.

- If disposat near the place of generation is not practicable, a regional disposal facility should serve a number of waste generating facilities.

- Disposal of solidified high-level radioactive waste will be carried out in deep geological repositories in suitable host rocks below the zone of active water movement, and separated from it by protective barriers.

- During disposal operations, the main waste isolation factor is the geological environment, as well as a good waste package.

- It must be in a region within a large "tectonic" area on a continent.

- It must be in a seismically inactive area (no higher than 5 on a 12-unit scale). 
- The host geologic formation should have a sufficient thickness and areal extent, with no tectonic disturbances, faults [believed to be within 2-3 km] or break zones; microfissures are allowed.

- The strata of the host rock formation must be close to horizontal and should be highly impermeable.

- Separation of the host rock formation from groundwaters must be by inpermeable formations at least 150-200 meters thick.

- No mineral resources should be present in the host geologic formation.

- A minimum of groundwater network should exist, with no productive groundwaters on the site.

- No extraneous boreholes or underground construction can be present on the site, with all boreholes to be mapped and sealed.

- The topography must have low retief for surface construction and access.

- There must be no zones of possible flooding, natural or man-made calamities.

With respect to siting a repository in salt, the Soviets would place a high priority on thick salt layers and a sequence of interbedded clays and salt. They wculd like to site a repository at 600-700 meters below the land surface (Lehmar 1989).

\subsubsection{Concept and Facility Description}

The disposal of HLW in geological formations in the Soviet Union was outlined in 1979 as having to comply with the following requirements (Kedrovskiy et al. 1979a):

- There must be reliable isolation from the biosphere for an untimited time period.

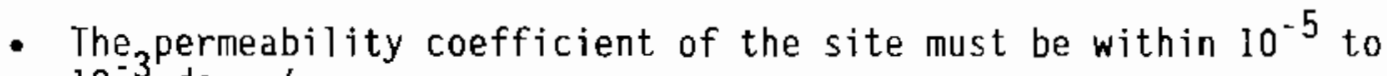
$10^{-3}$ darcy's.

- No release of radioactivity must occur for a distance of $400 \mathrm{~m}$ from the contour of the excavated repository.

- The repository must be located at a lower level than the zone of free water exchange, and there must be a protective rock mass of 70-100 m between this zone and repository. 
- The repository must be located at a distance not less than $1000 \mathrm{~m}$ from zones of tectonic dislocations and outside confines of current and expected mineral deposits.

- Large-scale testing of rock masses under "all basic loads," and surface-based testing of prototypes, was being considered. Electric heaters and "other sources of activity" would be used. It was mentioned that displacement of waste in the repository due to "rock fusion" would need to be assessed.

Several basic concepts have been considered by the Soviets for HLW disposal:

- Disposal of Consolidated Wastes in Mining Shafts

A mining shaft 4-6 $\mathrm{m}$ in diameter is constructed to a depth of 400 $800 \mathrm{~m}$. The consolidated wastes are packed in layers in the shaft by covering or mixing with quartz sand. Once the shaft is filled up to the mark made 150-250 m below the earth's surface, the repository is dried by heating to a temperature exceeding $100^{\circ} \mathrm{C}$ [probably due to radiogenic heating].

- Disposal of Consolidated Wastes in Drill Holes

Two general concepts for disposing of canistered and solidified wastes were discussed:

- A number of holes are drilled from the surface into a series of low-permeability rocks. The cans with the wastes, depending on the amount of the heat evolution, are placed either directly one behind the other, or alternating with plugs. The holes are filled with cans to a depth that assures the isolation of the wastes from the water exchange level. The remaining free part of the hole is filled with cement.

- If a site can be located in a thinly populated area, a repository can be constructed at a shallow depth. In this case the cans with the wastes are placed in drill holes bored in a series of thick clay deposits at a maximum depth of 40 meters.

- Disposal of Consolidated Wastes in Underground Chambers

The consolidated wastes, in cans or in containers, are placed into an underground chamber through a mining shaft or a drill hole which is provided with corresponding locking devices. Once the chamber has been filled with a planned amount of wastes, the hole or shaft is filled with cement for its entire height. The heat evolved from a large mass of wastes can cause the fusion of the surrounding rock. 
- Disposal of Consolidated Wastes in Underground Excavations

One of the methods is emplacement of cans or other containers in mine excavations (Kedrovskiy et al. 1979a).

Current potential Soviet concepts for disposal of HLW include natural voids, cavities, and caverns; deep boreholes; artificial "reservoirs"; special underground facilities; and shafts. The final, unused void spaces in a repository must be backfilled with dense material that does not shrink, decompose, or become modified (Kedrovskiy et al. 1989).

The geological formation is regarded as the main protective barrier. Also, man-made barriers and packages are required, at least through final disposat. A sketch of a conceptual deep disposal repository is given in the reference (Kedrovskiy et a). 1987).

\subsubsection{Research and Development}

The Ministry of Geology in the Soviet Union has carried out studies of geolog.cal and hydrological conditions in many regions for existing and planneri nuclear facilities. However, as of 1983, the results of all scientific and field studies had not yet provided a final answer on the most suitable tipe of rocks for waste disposal. Rock-salt, clays, granite, gneiss, diabast, porphyrite, and similar rocks were under consideration (Semenov 1983). Granite was mentioned to be the preferred host rock medium (Johnson 1989b), while another source indicated that the main siting areas now appear to be the jowlands surrounding the Caspian Sea for salt domes and bedded salt, and a Cambrian clay not far from Leningrad. Granite is considered unfavorable relative to salt and clay, due to "circulating water problems" (Lehman 1989).

other R\&D studies include estimating the maximum permissible thermal and radiation loads on the host rock formation, the requirements for the disposal facility, the basic principles of final disposal, and the requirements for suitable geological settings (Sedov et al. 1983). The Soviets have made calculations for HLW [phosphate glass] disposal in a 1-m-diameter well at a depth of more than $600 \mathrm{~m}$ in a rock having a permeability of $10^{-3} \mathrm{~m} / \mathrm{d}$ which show "safe cisposal for the fission product 1 ifetime" (Nikiforov et al. 1989). 
The USSR has expressed interest in waste disposal R\&D conducted in Canada's underground research laboratory (BBC 3/10/89).

\subsection{LOW-LEVEL AND INTERMEDIATE-LEVEL WASTE DISPOSAL SYSTEMS}

\subsubsection{Site Selection}

In 1970, the pilot and planned industrial NIIAR installations for underground disposal of liquid radioactive wastes were located in the northwestern part of the Melekess trough, within which is a thick formation of Paleozoic sedimentary rocks. The Melekess trough is part of the Volga-Kama artisian basin. The water-bearing formations that fall within the boundaries of the Melekess trough, with the exception of the Quaternary water-bearing horizon, contain mineralized waters and sodium chloride brines that are not suitable for industrial and domestic water supply (Spitsyn et al. 1970b).

"The Sanitary Regulations for the Design of Nuclear Power Stations" incorporates sanitary and hydrological requirements on siting solid waste burial grounds on the site. The basic requirement was that no ground or rain water should be allowed to penetrate into a storage vault (Gusev et al. 1977). Underground burial of LLW and ILW was felt to be possible by the Soviets in regions where the seismic activity did not exceed 7 on the Richter scale (Kedrovskiy et a1. 1979b).

In 1988, nine sites within the Soviet Union were being considered and were undergoing geologic characterization for use as possible regional repositories for low-level radioactive waste. Several final sites were expected to be selected in one or two years (Nucleonics Week $5 / 88$ ).

In June 1989, an article described a burial site for CMEA reactor waste [presumed to be LLW and/or ILW] in tunnels underneath the Yenisey River. This was described as follows by $N$. Savelyev (a journai ist).

"Dead center, there were five very long, rust-resistant pipes looking like five gun barrels mounted in the field. Not a living soul was to be seen near the mobile crane and concrete conduit. In the background, there was a birch coppice, a hamlet and a dusty road. We (with me in the car were Sergey Zadereyev, a writer, and Viktor Prokopenko, a local journalist) were making our way slowly, with stops, along the pipeline. Around $400 \mathrm{~m}$ into this uninhabited 
terrain the pipes disappeared, as if they had ceased to exist. The road suddenly turned into a quagmire. We spooked a flock of wild ducks and then drove into the field. From there it was constantiy uphill almost to the river itself. 'What are you building?'

Prokopenko asked in an artificially cheerful voice, breaking the prolonged silence. The peasants were not slow to reply: 'Surely you know we're building a subway. It's clear, isn't it?' They know how to keep a secret here. The "subway"--which is nothing less than a burial site being built for radioactive waste material from CEMA nuclear power stations-- is coyly called "Site No. 27" here. The site has recently given rise to much rumor and commotion. Only now, in the period of glasnost, has it become known what kind of tunnel is being excavated in the birch coppice. But ten years ago no one dared approach the facility closely, let alone ask questions. Journalist Viktor Prokopenko, former militiaman Yuriy Pirogov, and local doctors began picking their way through the screen of mystery and secrecy. At their insistence the kray party committee sent in an inpressive commission comprising geologists and specialists from civil defense, the State Committee for the Protection of the Environment, and the kray hea1th and epidemiology station. They measured radioactivity in several spots and acquainted themselves with the documents. A meeting with the public was then held and an official document read out there. According to this document the burial site will pose no danger to the environment. All the radioactive waste will, after processing, be pumped into the pipes of the tunnel (under the Yenisey) and thence transported into clay strata situated at a depth of $700 \mathrm{~m}$. In exchange for living next to the burial ground the villagers were promised new houses, a hospital and a hog-raising complex. All this munificence, discounting the $20 \mathrm{million}$ rubles al ready squandered on the tunnel under the Yenisey, comes to tens of millions of rubles spent on piping and concrete" (KOMSOMOLSKAYA PRAVDA 1989).

It was further reported in July 1989 that the waste disposal facility would be developed at the site of a previously secret plutonium production plant built in the 1950s.

"The plans involve building a tunnel under the Yenisei River--the second biggest in the USSR--to link the existing facility to a new urderground storage site on the other side that is being buitt 700 $f_{e}$ et below the surface in clay. The once exclusively military site is now taking waste from Soviet civilian nuclear plants and when extended will take waste from the whole of Comecon. The Krasnoyarsk ccmmunist party will be asking that the scheme be scrapped. A series of protest meetings has been held and over 60,000 signatures ccllected from opponents of the facility" (Nuclear Waste News $7 / \mathrm{B9a})$. 


\subsubsection{Concept and Facility Description}

In the Soviet Union, intermediate-leve? 1 iquid wastes that have been neutralized or made alkaline have been injected into deep geologic formations containing slow moving (fractions of meters per year) water located between water-tight strata [at least from the mid-1960s to about 1980]. As of 1978, the practice was given as the policy for disposing of liquid low-level and intermediate-leve] wastes at nuclear power stations with appropriate geology and hydrology (GKAE 1978, p. 9). Radioactive studies on nitrate-containing wastes were carried out to determine the formation of gases and other materials. Reference was made during a presentation that 100,000 curies (contained in more than $10^{6} \mathrm{~m}^{3}$ of solution) have been put into the ground (Spitsyn et a1. 1978). Also, tens of millions of curies in intermediate-level liquid wastes were disposed of in "reservoir beds" (Kondratyev et al. 1976), and long-term experience with this practice at the Scientific Research Institute of Atomic Reactors, NIIAR, confirmed this practice to be safe and reliable. The disposal concept resulted in an increase in the temperature of the host formation of a few degrees Celsius (GKAE 1978, p. 10.).

Experimental underground disposal of low-level liquid wastes in deep formations has been under way in the city of Melekess [now called Dimitrovgrad, near Ulyanovsk] since April 1966 and was continued at least until 1970. In April 1966, the NIIAR started operation of an experimenta] installation for the injection of radioactive solutions in geological prospecting drill hole R-3, which tapped into a water-bearing horizon at a depth of 1,432-1,508 m. Over a period of four years. $3.2 \times 10^{4} \mathrm{~m}^{3}$ of solutions containing about 3,500 curies of beta activity were pumped into the absorbing horizon (Spitsyn et al. 1970b) at an average rate of $7-9 \times 10^{4} \mathrm{~m}^{3} / \mathrm{yr}$ (Spitsyn et al. 1970a). It was found that the injected solutions migrated great distances along the stratum from the drill hole. [Note that this last statement differs significantly from ones made in the prior and following paragraphs.] (Spitsyn et al. 1970b). Unspecified gaseous wastes were also disposed of by injection into the well at Dimitrovgrad (New Scientist 4/21/77).

In 1970, 15 deep dri11 injection holes were finished and in operation at the Dimitrovgrad installation. The industrial installation at the NIIAR was 
designed for the underground disposal of radioactive solutions, with a maximum calculated capacity of $550 \mathrm{~m}^{3} / \mathrm{d}$. The useful volume for filling with wastes totalec $5.3 \times 10^{6} \mathrm{~m}^{3}$. This volume corresponded to the capacity for 30 years of underground disposal of the calculated volume of wastes (Spitsyn et a1. 1970b). Scrubbing of the cutting face zone with nitric acid increased receptivity somewhat (Spitsyn et a1. 1970a).

At an IAEA conference in 1979, it was again indicated that disposal of low-level and intermediate-level liquid radioactive wastes in geologic formations ty injection through drill holes into permeable strata bounded by aquitards was being seriously considered by the Soviets. The authors indicate that actual experiments with this form of disposal had achieved positive results (at the Ulyanovsk nuclear power station, for example [Gusev et al. 1977]). A brief theoretical mathematical analysis of radionuclide migration was a? so attempted (Kedrovskiy et a1. 1979b).

As of 1980, Jow- and intermediate-level wastes were still being disposed of in cuartz sandstone and clay structures at depths of about 1500 meters (BBC 8/1/80). Three protective zones were identified that surrounded deep well injection facilities for disposal of liquid radioactive wastes:

- The first zone is that where the disposal wells are located. This zone usually has an area of about 1.5-2 hectares. No construction is allowed here that is not related to the disposal facility, and no other use of this area is allowed.

- The second zone comprises the area of possible spread of the discharged liquid waste over the aquifers used for its disposal. The radius of the second zone is usually from 2-5 km. In this second zone, drilling of deep wells that were not associated with the disposal facility, installing large underground water intakes, and all underground activities are prohibited, because such activities could destroy the natural isolation capabilities of the disposal facility. The use of this second zone for agricultural purposes and for other building uses is not restricted.

- The third zone is established to rule out the possibility of deep oil, gas and other wells from removing contaminated groundwater. Based on calculations and experience in operating oil fields and these facilities, the radius of this zone is in the range of 10$20 \mathrm{~km}$, depending on the local geological and hydrogeological conditions (Gusev et al. 1977). 
The latest mention of well injection of liquid radioactive wastes "between platform-type artesian aquifers" indicates that the practice was undertaken to avoid the accumulation of wastes on the surface. The "natural rate of stratal water infiltration in these aquifers constitutes several meters per year." It was stated that this disposal method was not "absolutely reliable" and was unlikely to be used in the future (Nikipelov et al. 1990).

As of 1977 , solid radioactive wastes from Soviet nuclear power stations were disposed of onsite, as was done for liquid wastes, by being buried in special storage vaults. Low- and intermediate-level waste materials were generally collected separately. Solid waste storage vaults were built of concrete, and they were above the surface or partly underground. Facilities were provided near the storage vautts for monitoring the levels of radioactivity in the groundwater. Highly active wastes were put in specially shielded containers (Gusev et al. 1977).

As of 1981, to save storage space at RBMK power stations, the bituminized waste was poured into the onsite "repository" [or "pits" in another reference], and not placed in conventional storage facilities. However, this onsite "repository" is not considered to be the final disposal solution (Nikiforov et al. 1981a). In 1989, it was indicated that bituminized wastes were disposed of at the reactor site in a repository of a "pour type" (Nikiforov et a]. 1989).

Disposal of low-level wastes has been done in the Soviet Union [at least in the past] in concrete-lined trenches, with backfill and a covering of concrete. The top of the backfilled trenches is approximately at grade level. (a)

As of 1982, end fittings removed from spent fuel assemblies during reprocessing were disposed of by burial (Dubrovsky et al. 1982).

There are some 35 regionai stations for burying [10w-1evel] radioactive wastes [in addition to low- and intermediate-leve] wastes disposed of at reactor sites] in the USSR, according to B. Semenov, First Deputy Chairman of the GKAE. One is near Riga, Latvia, and one at the Radon test site near

(a) Personal knowledge from work of $K$. J. Schneider (PNL) when employed at the International Atomic Energy Agency in Vienna, Austria, 1980. 
Moscow (Semenov 1989). The Radon Waste Facility receives radioactive wastes from science, medicine, agriculture and industry, transported by special vehicles. Solidified radioactive wastes are disposed of in deep, underground, concrete chambers that enable the material to be isolated for 300 or even 500 years. The waste is isolated by metal, ferrous concrete, and the natural earth barrier of clay and loam. There has been no effect from the facility on the nearby environment, with fishing, and berry and mushroom collection taking place nearby ( $B B C 3 / 28 / 86)$. The Radon site, which has been accepting Moscow's waste since it began operation in 1962, is located in a clay sequence of up to 70 meters thick. The water table ranges from 4-20 meters below the land surface (Lehman 1989).

In 1989, information on the storage (disposal) of ionizing radiation sources, such as cobalt-60, was given by Sobolev. It appears that in the past, such sources were "discharged" through "curved" tubes into special underground areas. The storage areas were at a depth of $6 \mathrm{~m}$ and had a volume of 2001 . Each storage area is designed to receive $1.184 \times 10^{15} \mathrm{~Bq}$ (equivalent to about $50 \mathrm{~kg}$ of radium) and have a maximum temperature of $230^{\circ} \mathrm{C}$. It was indicated that such storage areas had been in use at the Moscow "Radon Production Cooperative" for over 20 years, and observations showed that this type of storage does not provide satisfactory safety. A new method of storage was developed in 1986 in a collaboration between the "Radon Production Cooperative" and the All Union Scientific Research Institute of Inorganic Materials in Moscow. The new method encapsulates the radiation sources in metal matrix blocks made of lead-based alloys. The metal blocks are then stacked in layers in storage areas, similar to those mentioned earlier, to a capacity of $6.66 \times 10^{15} \mathrm{~Bq}$ (Sobolev et al. 1989).

\subsubsection{Research and Development}

In the Soviet Union, bitumen blocks containing intermediate-level wastes with an activity of $10^{6}-10^{7}$ Becquere? s/ (about $0.00003-0.0003 \mathrm{Ci} / 1$ ) have been stored experimentally in clay soils (Semenov 1983). Bituminized LLW was placed in test burial grounds (in 2-m-deep trenches in clay formations) in the form of blocks weighing 1-2 MT with a radioactivity content of 0.01 0.09 curies. Core drilling of the burial grounds two years later showed no 
high radioactivity in the core, and rock $15 \mathrm{~cm}$ from the bitumen blocks had normal background radioactivity (Nikiforov et al. 1981a; Atomnaya Energia 1981).

Starting in 1961 and continuing at least through 1985, measurements were made of the migration of radionuclides in and around a $L L W$ "burial site." Radioactivity levels in the "wastewater" measured 10-20 Becquerels/liter and outlets of nearby reservoirs measured 0.5-1.0 Becquerels/1iter (Nazaryuk et a1. 1985). [These may be the same tests indicated by Nikiforov et a 1. in $1981 \mathrm{a}]$.

Further information was given in 1989 on these tests by Sobolev, who stated that several intermediate-level waste forms have been tested in the laboratory as well as in natural shallow clay formations for periods of 5-20 years. Intermediate-level wastes from RBMK reactor operations were solidified into "Portland"-type cement, bitumen and borosilicate glass having the following characteristics:

\begin{tabular}{|c|c|c|c|}
\hline Waste Form Type & $\begin{array}{c}\text { Waste } \\
\text { Content, } \%\end{array}$ & $\begin{array}{c}\text { Activity Level, } \\
\mathrm{mCi} / \mathrm{kg}\end{array}$ & $\begin{array}{l}\text { Density } \\
\mathrm{g} / \mathrm{cm}^{3}\end{array}$ \\
\hline $\begin{array}{l}\text { Portland Cement } \\
\text { Bitumen } \\
\text { Borosilicate Glass }\end{array}$ & $\begin{array}{l}10.7 \\
30.7 \\
30.0\end{array}$ & $\begin{array}{l}0.057 \\
0.089 \\
0.038\end{array}$ & $\begin{array}{l}1.7 \\
1.3 \\
2.6\end{array}$ \\
\hline
\end{tabular}

The waste forms were prepared and leach-tested at unspecified $1 a b-$ oratories, while the in situ or "natural" testing was performed at the Moscow Scientific Industrial Corporation (SIC) "Radon" disposal site--the specimens were placed at a depth of $2 \mathrm{~m}$ in "loamy soils" in "saucers which were precontacted with groundwaters, and were specially equipped for collecting the latter." Water samples were then taken from boreholes located nearby (Sobolev et al. 1989).

The leach-testing of these waste forms was used to generate release rates for use in making estimates, based on a "potential radiotoxicity index, " of the relative danger of environmental contamination due to waste form disposal. The results of the test, in terms of their "potential radiotoxicity index" indicated that the reduction in this index due to cement, bitumen and 
borosilicate glass ILW forms was 8,113 and 25,000 times, respectively. It was stated that this indicates the importance of the waste form itself as a barrier and argues strongly for the vitrification of ILW (Sobolev et al. 1989).

The final disposal concept for radioiodine removed from Soviet reactor and fuel reprocessing facilities has not yet been determined but was being studied as of 1981 (Nikiforov et a1. 1981b).

Near-surface disposal concepts for LLW and ILW have been studied that included the potential use of "pits" (Kedrovskiy et al. 1987).

\subsubsection{Cost Information}

In 1970, the costs of underground deep well injection of 1iquid wastes in the Soviet Union were 1.5-2 times less expensive than for evaporation and surface tank storage (4 rubles $/ \mathrm{m}^{3}$ instead of $6-8$ rubles) (Spitsyn et al. 1970a). The cost of incinerating $1 \mathrm{~m}^{3}$ of combustible wastes was given as less than 11 rubles in 1970 (Sobolev et a 1.1970 ).

In 1978 , costs of onsite deep-we 11 injection of liquid wastes were stated to be about $30 \%$ less expensive than conditioning by evaporation followed by bituminization [apparent7y excluding ultimate disposal] (GKAE 1978, p. 10).

The distribution of costs for treatment and storage of all radioactive wastes (i.e., LLW, ILW, and HLW) from Soviet nuclear power stations and from fuel reprocessing in 1983 were given as follows: HLW management costs represent $45-50 \%$ of the entire radioactive waste management system costs; ILW costs are $40-45 \%$; and LLW costs are $8-10 \%$. Final disposal was expected to increase the total waste management costs by as much as 20-30\% (Sedov et al. 1983). 



\title{
11.0 WASTE TRANSPORTATION SYSTEMS
}

\begin{abstract}
Information on Soviet waste transportation practices, primarily on transportation of spent fuel, is given in this section.
\end{abstract}

\subsection{SUMMARY}

The primary method of spent fuel transportation in the USSR is by rail car, although reference is made to barge and truck transport from the Kozloduy reacton storage site. A variety of transportation casks for spent fuel (dry or with water shielding) have been put into operation that reportediy conform to IAEA regulations. Transportation of wastes to regional disposal facilities is carried out by truck, rail, or barge.

\subsection{POLICY AND STRATEGY}

In the Soviet Union, the transportation of solidified radioactive wastes of all categories within plant boundaries may be carried out by trucks and rail cors without the use of special transportation packagings. Transportation outside of plant boundaries to regional disposal facilities is carried out by trucks, rail, or water transport using special transport packaging (Sedov et a1. 1988).

Transport of spent fuel has been carried out under regulations adapted from the IAEA transport regulations (including accident test conditions), in the USSR and the other CMEA countries (Kondratyev et a). 1977).

At its 124th meeting in Moscow, the Executive Committee of the CMEA adopted rules for the safe transport of spent fuel from nuclear power stations in CMEA countries by rail and sea. Part of the rules is a convention on liability for damage caused by an accident. The consequences of an accident are to be mitigated by the country wherein the accident occurred, but the damages are to be paid for by the country to blame for the accident (TASS $9 / 25 / 87$. 


\subsection{SPENT FUEL TRANSPORTATION SYSTEM}

\subsubsection{Packaging and Hardware System}

Rail cars for transporting spent fuel have casks that are placed vertically or horizontally, depending on fuel type. (VVER-440 spent fuel assemblies, $144 \mathrm{~mm}$ wide by $3200 \mathrm{~mm}$ long, are transported vertically; WVER1000 spent fuel assemblies, $238 \mathrm{~mm}$ wide by $4465 \mathrm{~mm}$ long, are transported horizontal7y; RBMK-1000 spent fuel assemblies, $79 \mathrm{~mm}$ in diameter by $10065 \mathrm{~mm}$ long, are transported horizontally.) The USSR has adopted a steel transport cask lined with stainless steel. Fins on the cask provide for impact resistance as well as for improving heat transfer. The casks weigh 73-110 MT and carry 9-30 spent fuel assemblies weighing 1.3-3.9 MT, depending on the cask and the spent fuel (Kondratyev et ar. 1977).

The railroad track gauge in the USSR is different from that used in the other CMEA countries (1520 mm vs. $1435 \mathrm{~mm}$ ). To accommodate this difference, transport cars between the USSR and the other CMEA countries have two sets of wheels (Kondratyev et al. 1977).

As of 1982 in the Soviet Union, nuclear power spent fuel was shipped dry in casks with the use of a cover-gas-filled cavity. Casks can handle 30 VVER440 fuel assemblies (approximately 3.8 MT uranium dioxide in the fuel) with up to 340 watts per assembly and 8 kilowatts of heat from the total spent fue? payload. Under these conditions the maximum fuel element cladding temperature is no higher than $200^{\circ} \mathrm{C}$, and the maximum gas temperature in the cask is $175^{\circ} \mathrm{C}$. For shipping VVER-440 spent fuel with exposures of greater than 24,000 MWd/MT, neutron shielding is required. This shield may be in a water jacket on the outer perimeter of the cask, and/or the cask may be filled with water (Dubrovsky et al. 1982).

Transportation of VVER-440 spent fuel is done primarily by railroad, using 4-8 special container cars (TK-6) with 12 axles each and two accompanying escort cars in a dedicated train. The casks are specified as meeting IAEA Type $B(U)$ requirements for spent fuel with exposures up to $23,000 \mathrm{MWd} / \mathrm{MT}$. In practice, some VVER-440 spent fuel was also shipped by truck and some by water (Dubrovsky et al. 1982). For RBMK fuel, other types of railway 
containers were used in conjunction with TK-11 rail cars [suc: as the TK-8] (Kondratyev et a1. 1977; Semenov 1983; Pushkov 1984; Dubrovsky et a1. 1982).

Variations in transportation packaging designs for more recent, higher exposure spent fuel have capacities of 6,8 or 10 spent fuel assemblies with either water or gas coolants (Pushkov 1984). For fuel burnup not higher than $24 \mathrm{GWd} / \mathrm{t}$ and total residual heat release not higher than $8 \mathrm{kh}$, it is preferable to use a nitrogen gas coolant during transportation (Veretennikov et a1. 1986).

The Soviets plan to use two types of spent fuel casks to transport spent fuel from WVE-1000 reactors. The TK-10 cask has a capacity of six assemblies or 3 MTU for fuel with exposure up to $50 \mathrm{GW} / M T U$, with up to $13 \mathrm{~kW}$ total heat, and a loaded weight of $98.6 \mathrm{MT}$. The cask has overall dimensions of $2.4 \mathrm{~m}$ in diameter and $6.13 \mathrm{~m}$ long, with the cavity being $5.03 \mathrm{~m}$ long. The TK-13 cask has a capacity of 12 assemblies or 6 MTU also for fuel with exposure up to $50 \mathrm{GW} / \mathrm{MTU}$, with up to $20 \mathrm{~kW}$ heat, and a loaded weight of $116 \mathrm{MT}$ (NEI 6/88b).

With WER-1000 reactors, spent fuel unloaded from reactor storage is possible only with the reactor shutdown. Reactor shutdown for fuel reloading is typically done in the summer. However, transportation is performed during the whole year through regions having considerable variations in temperature. Casks are thus designed for temperatures ranging from $-50^{\circ} \mathrm{C}$ to $+38^{\circ} \mathrm{C}$. The space between the jacket and the body of the TK-10 cask is filled with ethylene glycol solution. The TK-IO cask coolant is water or air [nitrogen]. Spent fuel assemblies are placed in a cask basket in which the tubes, filled with boron carbide powder, are used to provide nuclear safety. Each fuel assembly is surrounded by one of the 18 tubes (Kondratyev et a1. 1989).

The first shipment of VVER-1000 spent fuel was made from Unit 5 of NovoVoronezh in 1985 in TK-10 cask cars. Since 1988, transportation has been carried out in TK-13 cask cars. By February 1, 1989, 12 spent fuel trips were made, including:

$$
\begin{array}{ll}
\text { from Novovoronezh } & -7 \text { trips (TK-10) } \\
\text { from South-Ukrainian } & -3 \text { trips (2 TK-10, 1 TK-13) } \\
\text { from Kalinin } & -2 \text { trips (1 TK-10, 1 TK-13) } \\
& \text { (Kondratyev et a1. 1989). }
\end{array}
$$


A new design of the basket for VVER-1000 spent fuel assemblies is being developed in which neutron absorbers are not planned to be used. Work on the use of solid neutron shielding is being based on silicon-organic materials. (Kondratyev et a1. 1989).

A cask designated "Cask-19" is used to transport spent fuel from Soviet research reactors. The cask is solid steel with a cavity of $22 \mathrm{~cm}$ in diameter by about $125 \mathrm{~cm}$ long, and is sealed with a single heavy lid. Typically, four fuel assemblies are placed in a basket to comprise the payload. The maximum allowable heat generation rate of its cargo is about $360 \mathrm{~W}$. The cask is transported vertically on a rail car. The number of casks on a car depends on the spent fuel characteristics. The average service life of a cask is at least 20 years (Kritsky et al. 1988).

A Soviet journalist visiting a Soviet fuel reprocessing plant reported that the walls of a transportation cask used there were 376 mm thick and made of steel (Chertkov et al. 1989).

Characteristics of some of the USSR shipping casks for spent fuel are suminarized in Table 11.1.

IABLE 11.1. Characteristics of Some USSR Spent Fue] Transportation Casks

Overall Mass
Dimensions

Cask Con- Desig- Cask of a Body (m) Loaded Number of

Fuel Type figuration nation (MT) Diameter Height (MT) Assemblies

$\begin{array}{llllllll}\text { WVER-440 Vertical TK-6 } & 90 & 2.195 & 4.105 & 3.8 & 30\end{array}$

Cylinder

WWER-1000 Horizontal TK-10 $103 \quad 2$.
Cylinder

RBMK-1000 Vertical

Cylinder

TK-11 $86.5 \quad 2.195$

6.0

4.455

5

2.96

Note: The TK-11 cask is designed to transport fuel assemblies divided in two parts.

Reference: Philippov et al. (1989). 


\subsubsection{Cask Decontamination}

In the Soviet Union, shipping cask decontamination at the reprocessing plant is carried out in special chambers. Inner cask surfaces are washed using a rotating nozzle device. Decontamination is done by first spraying with alkali permanganate solution and then spraying with an acid solution containing oxalic acid with sodium hexamethaphosphate. Outer cask surfaces are treated by a foam-jet method using the same solutions but with foaming agent additives. Cask decontamination may also be done using an electrochemical method with a portable electrode. Acid solutions (phosphoric acid, sulfuric acid, etc.) are used as electrolytes. Decontamination capacity is up to "750 cathode working areas per hour" (Philippov et al. 1989).

Painted surfaces of casks and rail cars that cannot be cleaned using the foam-jət method are cleaned using special wash solutions containing dichloromethane (Philippov et al. 1989).

In the case of cask loading (or unloading) under water, the use of strippable polymeric coatings based on water-alcohol solutions of methylolpolyamide resin may be used (Philippov et a). 1989).

Te decontamination of the cask-car cargo section is carried out using oxalic acid and sodium hexametaphosphate, mixed with a foaming agent, sodium alkylsulphate. The decontamination efficiency may be increased by using a jet

of hea:ed water at $0.3-0.6 \mathrm{MPa}, 8-10 \mathrm{~m}^{3} / \mathrm{h}$, containing foam suppression additives such as polymethylsiloxane (Philippov et al. 1989).

Decontamination of transport baskets may be done using superheated steam that $i$ : condensed on the equipment surfaces in conjunction with the application a a decontamination solution. Another method uses a steam jet with a decontamination solution (Philippov et al. 1989).

\subsubsection{Management, Operations and Capabilities}

In some cases of transport of spent fuel, changes are made in-transit from one transportation mode to another. For example, from the Kozloduy nuclear power station in Bulgaria, railroads, highways and water modes are used (Kondratyev et a). 1977). 
The time required to transport spent fuel assemblies in Czechoslovakia from one unit of a nuclear power plant by train with four rail car-containers (TKC-30) and safe placement into the Soviet ISFSIs is about 21 days. Ten days are required to load the containers at a nuclear power plant site. The time required to complete loading of the train ready to transport spent fuel from the ISFSIs to the Soviet Union is estimated to be about 8 days. The first transport of spent fuel from the first Czechoslovakian unit to the ISFSIs was carried out in January 1987 (Petényi et a1. 1988).

As reported by a journalist visiting a Soviet fuel reprocessing plant, rail transport of spent fuel to a reprocessing plant is preceded by about one hour by another train that provides for inspection of the track and roadbed. The special train is inspected every 150-200 km. The walls of the cask are $376 \mathrm{~mm}$ of steel (Chertkov et al. 1989).

\subsubsection{Research and Development}

In 1984, an R\&D program was under way in the Soviet Union for transportation of spent fue? from fast reactors (Pushkov 1984).

The USSR is proceeding with R\&D on transportation of spent fuel using a steel rail cask and on storage of spent nuclear fuel, with emphasis on PWR fuel (Kondratyev et al. 1988).

\subsubsection{Safety and Qual ity Assurance}

Spent fuel shipping is carried out in accordance with Soviet regulations, "Rules for Safe Spent Fuel Transportation from Nuclear Power PTants" and "Spent Fuel Assemblies Specifications" (Dubrovsky et a1. 1982). Transport of spent fuel has been carried out under regulations adapted from the IAEA transport regulations (including accident test conditions), in the USSR and the other CMEA countries (Kondratyev et a1. 1977).

The VVER-440 casks with spent fuel exposures up to 23,000 MWd/MT are stated to meet IAEA Type $B(U)$ requirements (Dubrovsky et a1. 1982). 


\subsection{LOW- AND INTERMEDIATE-LEVEL WASTE TRANSPORTATION SYSTEM}

As of 1977 in the Soviet Union, special vehicles provided with extra biological shielding for the driver's cabin were used to transport solid waste to onsite burial grounds at nuclear power stations (Gusev et al. 1977). 



\subsection{REFERENCES}

Adamov, E. 1988. "Soviets Developing Enhanced RBMK," Nuclear Engineering International, May 1988, p. 2.

Afonin, M. A., A. A. Koprin, V. V. Korolev, L. N. Lazarev, Y. A. Pokhitonov and $V$. N. Romanovski. 1988. "Optimization of the Processes for Cesium, Strontium, RE and TPE Separation from Liquid Highly Radioactive Wastes by Extractant Based on Cobalt Dicarbolyde." Paper 50g presented at the American Institute of Chemical Engineers 1988 Summer National Meeting, August 21-24, Denver.

Aloy, A. S., A. S. Vixhnevsky, B. S. Kuznetsov, A. V. Trofimenko, and I. S. Faddeev. 1988. "Incorporation of Cesium Concentrates and Finely Dispersed Pulps into Vitreous and Ceramic Materials." Paper 50h presented at the American Institute of Chemical Engineers 1988 Summer National Meeting, August 21-2.4, Denver.

Aloy, A. S., B. Y. Galkin, B. S. Kuznetsov, R. I. Lyubtsev, and V. M. Esimantovskij. 1989. "Fractionation of Liquid Highly Radioactive Wastes and Incorporation of Long-Lived Radionuclides into Ceramics and Vitromet Compositions." Paper 8 (Session XXII) presented at Waste Management '89, February 26-March 2, Tucson, Arizona.

Atomiaya Energiya 1977. November 1977.

Atomaya Energiya 1981. "Scientific Insight into Soviet Handling of Radioactive Waste," February 1981, 50(2).

Atoms in Japan (AIJ) 4/87. "Blue Print for Nuclear Fuel Cycie Industry; Session 5 of Japanese Atomic Industry Forum," April 1987, p. 7.

Atoms in Japan (AIJ) 3/89. "JAIF 1988 Report on N-Plants: 420 Units in Operation World-Wide," March 1989, p. 27.

ATW News 8/84. "Castor for WWER-1000 Undergoing Acceptance Tests," Atomwirtschaft-Atomtechnik, Dusseldorf, Federal Republic of Germany, August 1984 , p. 7.

ATW News 11/88. "USSR Contract for Nukem," November 1988, p. 1.

Borisov, G. 8., A. S. Polyakov, and Z. S. Khasanov. 1990. "Testing of Some Fractory and Electrode Materials for Liquid Active Waste Vitrification Furnaces." Presented at the Waste Management '90 Conference, February 25March 1, 1990, Tucson, Arizona. 
Brazhneva, N. E., S. I. Kulakov, A. A. Minaev, E. L. Vakhonin, V. V. Uborskii, and B. K. Strausov. 1985. "Study of the Possibility of Vitrification of Wastes from Atomic Power Plants Employing Water-Cooled Reactors." Excerpt from Waste Management Research Abstracts №. 16, IAEA/WMRA/16, International Atomic Energy Agency, Vienna.

British Broadcasting Corporation (BBC) 8/1/80. "Burial of Nuclear Waste." Excerpt of talk by B. Belitskiy in answer to a question from a listener in Ireland. British Broadcasting Corporation, Summary of World Broadcasts.

British Broadcasting Corporation (BBC) 8/26/B2. "Transport of Spent Fuel to USSR." From Helsinki Home Service, British Broadcasting Corporation, Summary of World Broadcasts.

British Broadcasting Corporation (BBC) 6/16/84. "'People's Daily' Reports Secret Mining by USSR." Article from People's Daily, June 10, 1984. British Broadcasting Corporation, Summary of World Broadcasts.

British Broadcasting Corporation (BBC) 3/28/86. "Radioactive Waste Facility." Article from Pravda, March 15, 1986, with information from L. Khomchikof, the Radon Science and Production Association. British Broadcasting Corporation, Summary of World Broadcasts.

British Broadcasting Corporation (BBC) 5/15/87. "Electricity, Nuclear Power Prospects and Safety." Text of April 30, 1987 article in Sovetskaya Rossiya. by Y.I. Bublik and V.A. Legasov. British Broadcasting Corporation, Summary of World Broadcasts.

British Broadcasting Corporation (BBC) 11/12/87. "German Democratic Republic: Concern Dver Health Damage from GDR Uranium Mines." Report from the SFB Sender Freies Berlin West Berlin television station magazine programme "Kontraste," aired November 3, 1989.

British Broadcasting Corporation (BBC) 4/8/88. "Engineering; Nuclear Fue 1 Storage and Transport Facilities," British Broadcasting Corporation, Summary of World Broadcasts.

British Broadcasting Corporation (BBC) 9/1/88. "Report of Dumping of Radioactive Waste." A press briefing by Mr. Gerasimov, of the USSR Ministry of Foreign Affairs in Vienna, Austria on August 30, 1988. British Broadcasting Corporation, Summary of World Broadcasts.

British Broadcasting Corporation (BBC) 2/17/89. "Burial of Radioactive Waste." British Broadcasting Corporation, Summary of World Broadcasts.

British Broadcasting Corporation (BBC) 2/23/89. "Hungary; Review of Uranium Mining Comparative Economics and Agreement with USSR. ${ }^{\sharp}$ Article from a television broadcast [probably Hungarian] on February 12, 1989. British Broadcasting Corporation, Summary of World Broadcasts. 
British Broadcasting Corporation (BBC) 3/10/89. "Canada Nuclear Developments Nuclear Exchange." British Broadcasting Corporation, Summary of World Broadcasts.

Buldakov, L. A., S. N. Demin, V. A. Kostyuchenko, N. A. Koshurnikova, L. Yu. Krestinina, M. M. Saurov, I. A. Ternovskij, Z. B. Tokarskaya and V. L. Shvedov. 1989. "Medical Consequences of the Radiation Accident in the Southern Urals in 1957." Paper presented at the IAEA International Symposium on Recovery Operations in the Event of a Nuclear Power Plant Accident, Vienna, Austria, November 6-10, 1989.

Burmester, M., W. Rehak, and K. Willuhn, 1989. "Prototype Away-From-Reactor Storage Facility for WWER-Type Spent Fuel -- Technical Features and Safeguard Concept," Kernenergie, 32(19B9)2.

Cent al Intelligence Agency (CIA). 1985. USSR Energy Atlas. Superintendent of Discuments, U.S. Government Printing Office, Washington, D.C.

Cher"kov, V. 1989. "Special Purpose Facility: Report from a Nuclear Fuel Reprocessing and Storage Factory." Pravda, March 4, 1989, First Edition, Moscow, p. 6 .

Cooley, C. R. 1989. "Foreign Trip Report, IAEA International Waste Management Advisory Committee, Vienna, Austria," Office of Civi]ian Radioactive Waste Management, U.S. Department of Energy, Washington, D.C. Presentation fron A.S. Nikiforov, Aprii 10-14, 1989, Vienna.

Davydov, V. I., P. G. Dobrygin, V. V. Dolgov and G. A. Sergeev. 1976. "The KS-K-100 Pilot Plant for Vitrification of Radioactive Wastes; Results of Tria s With Waste Simulators." Paper SM-207/111 presented at the IAEA International Symposium on the Management of Radioactive Wastes from the Nuclear Fuel Cycle, March 22-26, Vienna.

Department of Commerce (DOC). I970. Papers presented at the Symposium on Treatment of Medium- and Low-Level Radioactive Wastes, September 7-11, 1970, Aix-en-Provence, France.

Department of Energy (DOE). 1987. Overall PIant Design Descriptions VVER Water-Cooled, Water-Moderated Energy Reactor, DOE/NE-0084, Revision 1, U.S. Department of Energy, Washington, DC 20585, October 1987.

Department of Energy (DOE). 1989. The Rovno Nuclear Power Plant Power Unit Number 3 Design Project, translation of "Rovenskaya Aes Energobloc No. 3 Proyekt. Tekhnicheskoye Obosnovaniye Bezopasnosti Sooruzheniya I Ekspluatatsii Aes". U.S. Department of Energy, Assistant Secretary for Nuclear Energy, April 1989 .

Department of State (DOS). 1988. "Soviets Offer Nuclear Waste Storage to the FRG." U.S. Department of State embassy communique in Bonn, Federal Republic of Germany (FRG) August 12, 1988. (Taken from FRG Journal "Der Spiegel," August 8, 1988.) 
Dollezhal', N. A. and I. Ya. Yemel'yanov. 1981. Channel Nuclear Energy Reactor, December 1, 1981.

Drozhko, E. G., B. V. Nikipelov, A. S. Nikiforov, A. P. Suslov and A. F. Tsarenko. 1989. "Experience in Radioactive Waste Management at the Soviet Radiochemical Plant and the Main Approaches to Waste Reliable Confinement Development." Paper presented at the International Symposium on the Safety Assessment of Radioactive Waste Repositories, Faris, France, October 9-12, 1989.

Dubrovsky, V. M., V. I. Zemlyanukhin, A. N. Kondratyev, Y. A. Kossarev, L. N. Lasarev, R. I. Lubtsev, Y. E. Mikerin, B. V. Nikipelov, A. S. Nikiforov, V. M. Sedov, B. I. Snakinsky and V. S. Shmidt. 1982. "The USSR Experience in Nuclear Power Plant Spent Fuel Handling Including Storage and Transportation." Paper IAEA-CN-42/88 presented at the International Atomic Energy Agency's International Conference on Nuclear Power Experience, September 13-17, 1982, Vienna.

Duffy, G. 1979. Soviet Nuclear Energy: Domestic and International Policies, R-2362-DOE, RAND, Santa Monica, California, December 1979.

Economist 5/10/86. "Uranium; Too Much of a Bad Thing?" U.S. Edition, p. 70

Energy Daily 10/24/78. "In Russia, Seven Ministries Have A Hand in Nuclear Development."

Energy Information Administration (EIA). 1989a. "Commercial Nuclear Power 1989 - Prospects for the United States and the World," D0E/EIA-0438(89), U.S. Department of Energy/Energy Information Administration, Washington, DC.

Energy Information Administration (EIA). 1989b. "World Nuclear Fuel Cycle Requirements 1989," DOE/EIA-0436(89), U.S. Department of Energy/Energy Information Administration, Washington, DC.

Fairha11. 1984. "UK Cuts Costs with Soviet Nuclear Deal." Manchester Guardian Weekly, Guardian Publication, Ltd., September 9, 1984, p. 3.

Fedorov, V.S. 1987. "Some Aspects of Designing Compact Spent VVER Fuel Storage." Paper presented at the International Atomic Energy Agency's Technical Committee Meeting on Spent Fuel Surveillance and Monitoring Methods. IAEA-TECDOC-461, October 27-30, Vienna.

Ferenc Takats. 1985. Spent Fuel Storage Alternatives for a VVER-440 Unit, FBS translation. Date unknown [probably 1985 judging from context].

Feuz, Dr. P. 1980. "Nuclear Power in Eastern Europe. Part I." Paper presented at the Swiss Association for Atomic Energy's Conference, March 3-4, Zurich, Energy in Countries with Planned Economies, March 1980, p. 4. 
Galkin, B. Ya., N. A. Rakov and V. N. Romanovskii. 1979. "Actinide Partitioning of Liquid High Level Wastes from Spent WVER Fuel Reprocessing," Kholpin Radium Institute. Paper presented at Fifth Meeting of International Technical Committee on High-Level and Alpha-Bearing Wastes, October 1-5, Cadarache, France.

GKAE (State Committee on Utilization of Atomic Energy). 1978. "The Main Methods of Solving the Problem of Radioactive Waste Management from Nuclear Power Stations and Spent Fuel Reprocessing PTants in the USSR." Papers of the USSR Delegation to the Session of the Working Group No. 7 ("Radioactive Waste Management"), of the International Atomic Energy Agency's International Nuclear Fuel cycle Evaluation, Moscow, USSR.

Gusev, D. I., A. S. Belitsky, A. D. Turkin. 1977. "Ways of Solving the Problems of Radiation Safety and Environmental Protection in Handling Radioactive Waste at Atomic Power Stations in the USSR." Paper CN-36/349 presented at tr:e International Atomic Energy Agency's International Conference on Nuclear Power and Its Fuel Cycle, May 2-13, Salzburg, Austria.

Hur?tert, G. C. 1983. Atomic Energy Clearing House, August 1, 1983.

Ignatenko, E. I., A. A. Matveev et al. 1986. "Experiment on the Increase of the Eurn-up Fraction of Fuel Assemblies in WVER 440 Reactor, "Atomnaya Energiyan, 61(4):240-242.

International Nuclear Fuel Cycle Evaluation Working Group 7 (INFCE WG 7). 1978. "Possible Ways of Localization of Tritium Containing Wastes Resulting from Fuel Recovery of Spent Fuel Elements of Atomic Power Stations." Informaticn paper by the USSR State Committee for the Use of Atomic Energy for the International Atomic Energy Agency's Working Group 7, November 30, 1978.

International Nuclear Fuel Cycle Evaluation Working Group 7 (INFCE WG 7). 1979. "Management of Wastes From Reprocessing Fast Reactor Spent Fuel." Information paper submitted by the USSR for the International Atomic Energy Agency's Working Group 7, March 15, 1979.

International Atomic Energy Agency (IAEA) 1982. Storage of Water Reactor Spent Fuel in Water. Pools, Survey of World Experience. Appendix H, "Some Aspects of Spent Fuel Storage in Water Pools in the USSR." Technical Report Series No. 218, Vienna.

International Atomic Energy Agency (IAEA) 1987. The Nuclear Fuel Cycle Information System, An International Directory of Nuclear Fuel Cycle Facilities, IAEA-TECDOC-408, Vienna.

International Atomic Energy Agency (IAEA). 1988. Operating Experience with Nuclear Power Stations in Member States in 1987. Vienna.

Johnson, A. B. 1986. "Foreign Travel Report, BEFAST Meeting, Leningrad, USSR. May 23-June 2 1986." Pacific Northwest Laboratory, Richland, Washington. 
Johnson, A. B. 1989a. "Monthly Report on International Activities for the Commercial Spent Fuel Management Program, WBS-41." Letter to J. M. Creer, Pacific Northwest Laboratory, Richland, Washington, January 31, 1989.

Johnson, A. B. 1989b. Foreign Travel Report, June 5 through June 9, 1989 Topic: IAEA Technical Committee Meeting - Vienna Austria "Influence of Radiation on Corrosion of Structural Materials" Pacific Northwest Laboratory, Richland, Washington.

Kedrovskiy, 0. L. Ye. A. Leonov, N. M. Romadin, and I. Yu Shishchits. 1979a. "Program of Investigation Studies Concerning the Permanent Disposal of HighLevel Radioactive Wastes in Deep Low Permeability Geological Formations." Paper presented at International Atomic Energy Agency Symposium on the Underground Disposal of Radioactive Wastes, July 2-6, Helsinki, Finland, State Committee for the Utilization of Atomic Energy in the USSR.

Kedrovskiy, 0. L., M. K. Pimenov, N. A. Rakov, A. I. Rybalchenko and F. L. Yudim. 1979b. "Principles Governing the Evaluation of the Safety of Underground Burial of Liquid Radioactive Wastes in Deep Geologic Formations, and Ways of Safety Increase." Paper presented at Iriternational Atomic Energy Agency Symposium on the Underground Disposal of Radioactive Wastes, JuTy 2-6, Helsinki, Finland, State Committee for the Utilization of Atomic Energy in the USSR.

Kedrovskiy, 0. L., et al. 1987. "Main Directions to Solve the Problem of Reliable Isolation of Radioactive Waste in the USSR." Paper IAEA-CN-48/259 presented at the International Atomic Energy Agency's Internationa? Conference on Nuclear Power Performance and Safety, (English Abstract), IAEA, September 28 - October 2, Vienna.

Kedrovskiy, 0. L., E. A. Leonov, and I. Y. Sheeshiz. 1989. "Principles and Requirements for Siting of Underground Repositories for Solidified Radioactive Waste in Geological Environments." Paper 6-27 presented at Waste Management '89, February 26-March 2, Tucson, Arizona.

Kochetkov, L. A., V. B. Lytkin, and M. F. Troyanov. 1980. "Development of Fast Breeder Reactors in the USSR." Paper presented at the Swiss Association for Atomic Energy/Foratom's conference "The Breeder Reactor and Europe," October 14-17, 1979, Lucerne, Switzerland, Enerqy in Countries With Planned Economics, January 1980 , pp. 4-6.

KOMSOMOLSKAYA PRAVDA. 1989. "Krasnoyarsk Nuclear Waste Project Attacked," PM2106094389, [N. Savelyev article under the "Regular Daily Spot" rubric: "Tunneling Under the Yenisey"], June 15, 1989, p. 1.

Kondratyev, A. N., I. L, Rybalchenko, V. M. Sedov, and A. A. Konikevich. 1970. "Engineering and Economic Aspects of the Ireatment of Radioactive Wastes of Research Centers and Atomic Power Plants," SM-137/82. Paper presented at the Symposium on Treatment of Medium- and Low-Level Radioactive Wastes, September 7-11, 1970, Aix-en-Provence, France. 
Kondratyev, A. N., Y. P. Martynov and M. V. Strakhov. 1976. "Management of High-Level and Alpha-Emitting Waste in the USSR." Paper 76-001/03 (translated from Russian), International Atomic Energy Agency, Vienna.

Kondratyev, A. N., Y. A. Kosarev, and E. I. Yukilov. 1977. "Spent Fuel Transportation Problems." Paper $\mathrm{CN}-36 / 316$ presented at the International Atomic Energy Agency's International Conference on Nuclear Power and Its Fuel Cycle, May :-13, Salzburg, Austria.

Kondratyev, A. N., V. V. Kulichenko, I. I. Kryukov, N. V. Krylova, V. I. Paramoshkin and M. V. Strakhov. 1979. "Surface Reservoirs of Vitrified HighLeve" Radioactive Wastes." Paper SM-243/112 presented at International Atomic Energy Agency's Symposium on Underground Disposal of Radioactive Wastes, July 2-6, Otaniemi, Finland.

Kondratyev, A. N., V. A. Kurnosov, I. Ye. Kiyko, I. L. Rybalchenko, V. V. Spichev, M. N. Suhoruchenkov and N. S. Tikhonov. 1986. "Spent Fuel Storage Deve opment in the U.S.S.R." Paper presented at the International Atomic Energy Agency Technical Committee Meeting on Behavior of Used Fuel Assemblies and Storage Equipment at Long-Term Wet Storage Conditions, May 26-31, 1986, Lenirigrad, U.S.S.R.

Kondratyev, A. N. 1988. Referenced in article: "Experts Discuss Transportation and Storage of Spent Fuel at JAIF-GKAE Seminar." Atoms in Japan, Noveriber 1988, p. 28.

Kondyatyev, A. N., V. N. Yershov, Yu. V. Kozlov, Yu. A. Kosarev, Yu. V. Ilyin and M. S. Pavlov. 1989. "Experience and Prospects of VVER-1000 Reactor Spent Fuel Transport." Paper presented at PATRAM '89, International Symposium on Packiging and Transportation of Radioactive Materials, June 12-15, 1989, Washington, D.C.

Konstantinovich, A. A., V. V. Kulichenko, V. A. Bel'yukov, A. S. Nikiforov, B. V. Nikipelov, S. E. Stepanov, L. I. Baskov and S. I. Kulakov. 1976. "Features of a Process for Vitrifying Radioactive Wastes Without Precalcination and Fiadionuclide Behavior in the Process." Paper SM-207/107 presented at the International Atomic Energy Agency's International Symposium on the Management of Ridioactive Wastes from the Nuclear Fuel Cycle, March 22-26, Vienna.

Kritsky, V. G., G. V. Mikhailov, N. S. Tikhonov, T. F. Makarchuk and V. I. Ivanciv. 1988. "Research Reactor Fuel Handling." Paper presented at International Atomic Energy Agency's Technical Meeting on Research Reactor Fuel Handling. Vienna, November 1988.

Kulichenko, V. V., N. V. Krylova and I. 1. Kryukov. 1979. "Properties of High-Level Radioactive Wastes Affecting Their Behavior After Burial in Geolcigic Formations." Paper presented February 1979, at Helsinki, Finland, USSR State Committee for Utilization of Atomic Energy. 
Kyodo News Service. 1988. "Soviet Official Confirms 1957 Nuclear Disaster." Interview with Y. Velikhov in Tokyo, Japan, following his lecture to Japan's Science and Technology Agency and the Ministry of International Trade and Industry, December 6, 1988.

Laskorin, B. N., V. A. Mamilov, Y. A. Koreisho, D. I. Skorovarov, L. I. Vodolazov, I. P. Smirnov, 0. L. Kedrovskiy, V. P. Shulida, B. V. Neviskiy, and V. N. Mosinets. 1982. "The Mining and Processing of Uranium Ores in the USSR." Paper CN-42/356 presented at the International Atomic Energy Agency's International Conference on Nuclear Power Experience, September 13-17, Vienna.

Lehman, L. L. 1989. "Nuclear Waste Management and Nuclear Related Accidents in the Soviet Union." Briefing for the National Academy of Sciences, Washington, D.C., L. Lehman \& Associates, Burnsville, Minnesota, December I, 1989.

Leigh, I. W. 1989. International Nuclear Fuel Cycle Fact Book, PNL-3594, Rev. 9, Pacific Northwest Laboratory, Richland, Washington.

MacLachlan, A. 1989. "Glasnost and ChernobyT: Soviet Nuclear Power at the Crossroads." Nucleonics Week, March 16, 1989, F. 9.

McElroy, J. L. 1989. "Foreign Travel Report: International Atomic Energy Agency, Vienna, Austria," May 19-27, 1989, from paper prepared by the USSR State Committee on the Utilization of Atomic Energy, "Development of Methods for the Vitrification of High-Level Wastes in tre USSR, "Pacific Northwest Laboratory, Richland, Washington.

Minaev, A. A., I. M. Kotelkin, S. I. Kulakov, V. V. Uborskii, E. N. Dregalina, V. K. Strausov and N. E. Brezhneva. 1985. "Study of the Possibility of Solidification of Wastes from Atomic Power Plants by Hot Pressing." Waste Management Research Abstracts No. 16, IAEA/AMRA/16, International Atomic Energy Agency, Vienna.

Moscow Domestic Service. 1989. "Data on 1957 South Urals AES Accident Declassified." LD2006170689, June 20, 1989, p. 71.

Moscow TRUD. 1989. "Nuclear Fuel Storage Facility Questioned," 51000001z, [Article by 6. Kiyucherov: "A Secret Facility?";, March 30, ]989, p. 4.

Natural Resources Defense Council (NRDC). 1989. "NRDC Technical Team Releases New Information on Unprecedented Nuclear Warhead Monitoring and Visits to Secret Military Facilties in Soviet Union, "News Release from the NRDC, July 12, 1989, Washington, D.C.

Nazaryuk, A. S., S. B. Ostroglyadov, L. M. Prokazova, I. A. Sobolev and L. M. Khomchik. 1985. "Environmental Protection and Making Radioactive Wastes Safe." Waste Management Research Abstracts No. 16, IAEA/WMRA/16, International Atomic Energy Agency, Vienna. 
News and Comment 6/89. "Soviets Admit 1975 Nuclear Mishap." June 23, 1989, D. Dickson.

New Scientist 4/21/77. "The Soviet Answer to Nuclear Waste," v.74(1048):128.

New Scientist 1/10/80. "The Wasteful Truth About the Soviet Nuciear Disaster."

Nikiforov, A. S., M. I. Zhikharev, V. I. Zemlyanukhin, V. V. Kulichenko, I. E. Nakhut in, A. S. Polyakov and N. A. Rakov. 1981a. "Management of Radioactive Wastes from Nuclear Power Stations in the USSR." Paper SR-57/61 presented at International Atomic Energy Agency's Seminar on the Management of Radioactive Waste from Nuclear Power P1ants, October 5-9, Karlsruhe, Federa] Republ ic of Germany.

Nikiforov, A. S., M. I. Zhikharev, V. I. Zemlyanukhin, V. V. Kulichenko, I. E. Nakhut in, A. S. Polyakov, and N. A. Rakov. 1981b. "Handling Radioactive Wastes from Nuclear Power Plants and Reprocessing Spent Nuclear Fue1," UDC E21.039.71. Translated from Atomnaya Enerqiya, 50(2):128-136, February 1981, Plenum Publishing Corporation, p. 116.

Nikiforov, A. S., A. I. Borzunov, A. F. Votintsev, V. I. Davydov, V. V. Dolgov, A. P. Eperin, V. A. Kurnosov, M. K. Martynova, A. S. Polyakov, K. D. Rogov, V. M. Sedov, M. V. Strakhov and S. N. Filippov. 1986. "Facility for Bituminizing Liquid Radioactive Wastes From the Leningrad Nuclear Power Plant," UDC 621.039.746. Translated from Atomnaya Energiya, 61(3):162-166, September 1986, Plenum Publishing Corporation.

Nikiforov, A. S., A. S. Aloy, V. V. Dolgov, Yu. V. Kuznetsov, V. V. Kulichenko, B. V. Nikipelov, V. I. Osnovin, A. S. Polyakov, V. M. Sedov, V. T. Sorokin and S. N. Filippov. 1988. "Dealing With Highly Active Wastes Formed in Nuclear-Fuel Regeneration," 0038-531X/87/6305-0818, Plenum Publishing Corporation (translated from Atomnaya Energiya, 63(5)pp. 319-323, Novernber 1987.

Nikiforov, A. S., B. V. Nikipelov and V. V. Kulichenko. 1989. "Policy and Principles of Radioactive Waste Management In USSR." In Low and Intermediate Level Radioactive Waste Management, Proceedings of the 1989 Joint International Waste Management Conference, October 22-28, Kyoto, Japan, The American Society of Mechanical Engineers, New York, NY.

Nikipelov, B. V. 1989. "Experience in Managing the Radiological and Radioecological Consequences of the Accidenta? Release of Radioactivity Which Occurred in the Southern Urals in 1957." Paper presented at the IAEA International Symposium on Recovery Operations in the Event of a Nuclear Power Plant Accident, Vienna, Austria, November 6-10, 1989.

Nikipelov, B. V., A. P. Suslov, and A. F. Tsarenko. 1990. "Perspective." Presented at the Waste Management '90 conference, February 25-March 1, 1990, Tucson, Arizona. 
NOVA. 1989. "Back to Chernobyl", NoVA Television Broadcast, Juły 18, 1989, Washington, D.C.

Nuclear Engineering International (NEI) 12/87a. "Paying for Decommissioning," p. 8 .

Nuclear Engineering International (NEI) 12/87b. "Attommash Going Too Fast," p. 9.

Nuclear Engineering International (NEI) 5/88. "UK-USSR Exchange on Regulation Agreed, " p. 7.

Nuclear Engineering International (NEI) 6/88a. "Profile of $V / 0$ Atomenergoexport, " p. 37.

Nuclear Engineering International (NEI) 6/88b. "Soviets Concentrate on the PWR and Work on Advanced Concepts," p. 32.

Nuclear Engineering International (NEI) 10/88. "Soviets Still Planning BatchProduced Series of FBRs," p. 38. (Review of a paper, "The Development of

Sodium-Cooled Fast Reactors and Possible Ways of Improving Their Technical ard Economic Performance," by M. F. Troyanov et al., at the IAEA's International Conference on Nuclear Performance and Safety, Vienna, September 28 to October 2, 1988.)

Nuclear Engineering International (NEI) 12/88. "Soviet Delays Exposed," p. 6. Nuclear Engineering International (NEI) 3/89. "Improving Safety Practices in the Soviet Union," p. 15.

Nuclear Engineering International (NEI) 4/89. "Three Years After Chernobyl: Soviet Public Opposition Grows," p. 28.

Nuclear Engineering International (NEI) 10/89. "Soviets Take International View," p. 10.

Nuclear Engineering International (NEI) 10/89. "Five Years More for Urals Cleanup," p. 11.

Nuclear Engineering International (NEI) 10/89. "Still Counting the Costs," p. 12 .

Nuclear. Europe 1-2/88. "USSR Relies on Reprocessing to Close Its Fuel Cycle," January-February 1988, p. 49. (From an essay by E.I. Mikerin, in the journal Atomnaya Energiya, November 1987, and from remarks by the author in a brief speech at a nuclear fuel cycle specialists' meeting organized by the Finnish TV0 utility in Helsinki on November 9,1988 ).

Nuclear Fuel 6/84. "France and USSR Consider Experimental Dry Reprocessing for Breeder Fuel," June 4, 1984, p. 14. 
Nuclear Fuel 11/87. "Soviets Begin Construction of Plant to Reprocess Fue] from WER-1000s," November 30, 1987, p. 12.

Nuclear Fue1 10/88. "Canada, USSR Sign Agreement Covering Soviet Enrichment of Canadian Uranium," October 31, 1988, p. 7.

Nuclear Fuel 2/89. "Soviets are Said to Offer SWU to Korea," February 6, 1989 , p. 5.

Nuclear Fuel 3/89. "Industry Disputes Watkins' Data on Imports of Soviet U, Enrichment," March 20, 1989, p. 3.

Nuclear Fuel 4/89. "DOE, Congress Hot on Soviet SWU Imports but Utilities Not Yet Showing Concern," April 3, 1989, p. 2.

Nuclear Fuel 6/89. "Soviet Centrifuge Capacity Said to Free More Low-Cost SWU for Western Markets," June 26, 1989, p. 1.

Nuclear Fuel 10/89a. "Soviet Union Postpones Completion of Siberian Reprocessing Plant," October 16, 1989, pp. 1-2.

Nuclear Fuel 10/89b. "Soviet SWU Officials Visit U.S. Firms," October 30, 1989 , pp. 2.

Nuclear Fuel 10/89c. "Soviet Official Says Centrifuge Process Allows TSE Flexibility for ShU Sales," October 2, 1989, pp. 6.

Nuclear Fuel 11/89. "Soviets Have 5-Million SWU for Sale," November 27, 1989, p. 14 .

Nuclear Fuel 12/89. "Canada, Soviet Union Agree to Further Nuclear Trade, Including U Development," December 11, 1989, p. 5.

Nuciear Fuel 3/90a. "U Market Volume Jumps Unexpectedly, but UF 6 Glut Hoids Down $\mathrm{U}_{3} \mathrm{D}_{8}$ Prices," March 5, 1990, p. I.

Nuclear fuel 3/90b. "U Miners Ask Administration to Address Soviet 'Dumping' in Ne' Trade Talks," March 5, 1990, p. 4.

Nuclear News 10/86. "Chernobyl: The Soviet Report," October 1986, p. 59.

Nuclear News 8/87. "World List of Nuclear Power Plants," August 1987.

Nuclear News 5/88. "Enhanced Safety P1anned for RBMKs and WVERs, "May 1988, p. 77. (From a paper by Yevgeny Adomov presented at the IAEA's International Symposium on Severe Accidents in Nuclear Power Plants, Sorrento, Italy, March 21-25).

Nuclear News 8/88. "International Briefs," August 1988, p. 66. 
Nuclear News 11/88. "The Soviets Foresee Having About 150 GWle of Nuclear," November 1988, p. 147. (Information from Alexander Protsenko, Chairman of the USSR State Committee on the Utilization of Atomic Energy.)

Nuclear News 1/89. "The Latest Civilian Nuclear-Powered Ship," January 1989, p. 108 .

Nuclear News 2/89. "World List of Nuclear Power Plants," February 1989.

Nuclear News 5/89. "Soviets Measure Lingering Chernobyl-4 Contamination. "May 1989, p. 68.

Nuclear News 8/89. "World List of Nuclear Power Plants," August 1989.

Nuclear News 10/89. "Zaporozhye-5 Has Entered Operation," October 1989, p. 59.

Nuclear News 11/89. "New Observations of Soviet Nuclear Power, "November" 1989 , pp. $67-70$.

Nuclear News 1/90a. "More on Soviet Urals Accident," January 1990, p. 18. (Letter to the editor by a U.S. member of a People-to-People delegation to the USSR, September 25-October 5, 1989.)

Nuclear News 1/90b. "More Details Presented on 1957 Urals Accident," January 1990, pp. 74-75.

Nuclear Regulatory Commission (USNRC). 1987. "Report on the Accident at the Chernobyl Nuclear Power Station," NUREG-1250, U.S. Nuclear Regulatory

Commission, Washington, DC, January 1987.

Nuclear Waste News 9/85. "Swedish Radio Claims Estonian Nuclear Waste Disposal Site Leaks Radiation," September 12, 1985, p. 224. (A claim by a defected Soviet engineer in Sweden).

Nuclear Waste News 7/89a. "Soviet Plans to Build Nuclear Waste Facility in Siberia Face Protests," July 13, 1989, p. 255.

Nuclear Waste News 7/89b. "News Briefs," July 27, 1989, p. 275.

Nuclear Waste News 9/89. "Slants \& Trends," September 21, 1989, p. 337.

Nuclear Waste News 11/89. "Australia, USSR May Sign Dea? for Soviet Use of Synroc, " November 23, 1989, p. 433.

Nuclear Waste News 3/90. "Estonia Asks Finnish Aid in Halting Baltic Radioactive Contamination," March 15, 1990, p. 107.

Nucleonics Week 9/80. "Top Official Provides Glimpse into Soviet Nuclear Program," September 4, 1980. (Based on an interview of Nucleonics Week editor with Soviet officials). 
Nucleonics Week 1/86. "Soviet Plan Calls for Serial Breeder Production and 1,600 MW FBR," January 2, 1986, p. 11 (From a press conference with B.A. Semenov).

Nucleonics Week 4/87a. "USSR Abandons Chernobyl-5 and -6 But Will Finish Other RBMKs", Apri] 30, 1987, p. 8.

Nucleonics Week 4/87b. "Legasov Says German-Soviet Research Efforts Aimed at HTGR:" Apri1 30, 1987, p. 9.

Nucleonics Week 11/87. "Soviets Designing 1,800-MW PWR For Next Generation of VWERs, " November 12, 1987, p. 3.

Nucleonics Week 1/88. "USSR: Chernobyl Cost Revised," January 21, 1988, p. 14.

Nucleonics Week 4/88. "U.S., USSR Sign Safety Pact," April 28, 1988, p. 3.

Nucleonics Week 5/88. "Soviet Specialist Describes Plans for Low-Level Waste," May 19, 1988, p. 3. (An interview with Leonid Chamjanov).

Nucleonics Week 9/88a, "USSR to Build PWR Station Near Border with Finland," September 1, 1988, p. 1 .

Nucleonics Week 9/88b, "Minsk District Heating Reactor Said Abandoned by Pub1 ic Demand," September 15, 1988, p. 3.

Nucleonics Week 10/88. "Germans and Soviets Agree to Cooperate on Modular HTRs." October 27, 1988, p. 1.

Nucleonics Week 12/88. "Velikhov Terms Public Opinion Major Issue for Soviet Union," December 8, 1988, p. 3.

Nucleonics Week 2/89. "USSR Acadamy of Sciences to Create Institute of Nuclear Safety," February 16, 1989, p. 3.

Nucleonics Week 3/89. "Armenian Units to be Converted to Gas or 0i1," March 9,1989, p. 3.

Nucleonics Heek 7/89a. "First Commerical Contract for German-Soviet HTR Ready Soon," July 6, 1989, p. 2 .

Nuclénics Week 7/89b. "USSR Nuclear Power Ministry Folded Into Defense Grout," July 27, 1989, p. 7 .

Nucleonics Week 8/89. "USSR: Supreme Soviet Approves Nuclear Program," August 10,1989, p. 14.

Nucleonics Week 10/89a. "Chernobyl Study Center Proposal Gets Cautious Reception in Vienna," October 5, 1989, p. 1. 
Nucleonics Week 10/89b. "Soviet WVER-1000 Sale to India Said Delayed by Money Terms, " October 12, 1989, p. 1 .

Nucleonics Week 11/89a. "Post-Chernobyl Cleanup Entering Longer-Term Phase, Soviets Say," November 2, 1989, pp. 5-6.

Nucleonics Week 11/89b. "Soviets Use Prussian Blue to Stem Doses from Chernobyl, " November 9, 1989, p. 13.

Nucleonics Week 12/89. "Nuclear Cooperation Foreseen Under EC-USSR Economic Accord," December 21, 1989, p. 9.

Parker, F. L. 1983. "Search of the Russian Scientific Literature for the Descriptions of the Medical Consequences of the Kyshtym "Accident". ONWI424, Office of Nuclear Waste Isolation, Battelle Project Management Division, Columbus, Ohio.

Pepeski, R. 1989. "Soviet Union Shifting to Hydroelectric Power After Chernobyl." The Reuter Library Report. Quotations from B. Kartelev, Director of the Soviet Institute for Hydrotechnics in an interview by "Pravda." January 30, 1989.

Petényi, V., V. Polák, M. Vandlíková, J. KmoJena, D. Belko. 1988. "Spent Fuel Management in Czechoslovak WVER-440 Type Reactors". Proceedings of an Internationa] Atomic Energy Agency Advisory Group Meeting on Spent Fue? Manaqement: Current Status and Prospects, IAEA-TECDOC-487, Vienna.

Philippov, Ye. M., and S. A. Nikiforov. 1989. "Radioactive Contamination and Decontamination of Storage Facilities and Transport Equipment for VVER and RBMK Spent Fuel." Paper presented at the International Atomic Energy Agency Technical Committee Meeting on Decontamination of Transport Casks and Spent Fuel Storage Facilities, April 4-7, 1989, Vienna.

Polyakov, A. S., G. B. Borisov, Z. S. Khasanov, and N. I. Moiseenko. 1989. "Development of Electrodes for a High-Level Waste Vitrification Furnace." Paper 6-26 presented at Waste Management '89, February 26-March 2, Tucson, Arizona.

PRAVDA. 1989. "Report on P1ant Conversion," PM1707160389, July 17, 1989, Moscow, Second Edition, pp. 1, 4.

Pushkov, A. A. 1984. "Spent Fuel Management in the USSR." Paper presented at the International Atomic Energy Agency's Advisory Group Meeting, March 27-30, Vienna.

Radwaste News 10/27/88. "West Germans Deal With Moscow," October 27, 1988, p. 146 . 
Renard, E. V., and B. S. Zacharkin. 1988. "Hot Laboratory Experiments on Fast Reactor Spent Fuel Liquid Extraction Reprocessing in the USSR. Paper $3 \mathrm{~g}$ presented at the American Institute of Chemical Engineers 1988 Summer National Meeting, August 21-24, Denver.

Report on Defense Plant Wastes 1/90. "U.S., Soviets Agree to First Nuclear Contamination Project," January 19, 1990, p. 18.

Rippon, S. 1984. "Nuclear power growth in the Soviet Union," Nuclear News, February 1984, p. 62.

Romanenko, V. S., and A. V. Krayushkin. 1982. "Physical Characteristics of an RBMK Reactor in the Transitional Period." Translated from Atomnaya Energiya, Vol. 53, No. 6, pp. 367-373, December 1982 (original article submitted January $29,1982$.

Romanov, G. N. 1989. "Formation of Dose Burdens to Man and the Environment. Long-Term Management of an Area Subjected to Radioactive Contamination as a Result of a Radiation Accident Beyond the Design Basis." Paper presented at the IAEA International Symposium on Recovery Operations in the Event of a Nuclear Power Plant Accident, Vienna, Austria, November 6-10, 1989.

Rybalchenko, I. 1988. "Main Principles of Safe Removal, Conditioning, Transportation and Storage/Disposal of Severely Damaged Nuclear Fuel and other Accijent Generated Waste." Paper presented at an IAEA Advisory Group Meeting, Decenber 12-15, Vienna during an IAEA Project on Post Accident Management of Severely Damaged Nuclear Fuel and Radioactive Waste Arising.

Saltzman, J. D., and C. R. Cooley. 1987. "Foreign Trip Report, IAEA Technical Review Committee on Underground Disposal of Radioactive Waste, Vienna, Austria, January 26-28, 1987." U.S. Department of Energy, Washington, D.C.

Sapornikov, G. 1988. "Bituminization of Liquid Active Wastes at Nuclear Power Plants in the USSR." Paper $34 \mathrm{f}$ presented at the American Institute of Chemical Engineers 1988 Summer National Meeting, August 21-24, Denver.

Seaborg, G. S., et a1. 1963. Atomic Energy in the Soviet Union, Trip report of tie U.S. Atomic Energy Delegation, U.S. Atomic Energy Commission, Washington, O.C., May 1963.

Sedor, V. M., A. S. Nikiforov, M. V. Strakhov, V. T. Sorokin, E. A. Shashukov, M. I. Zavadskii, and A. F. Nechaev. 1983. "Effect of Waste Reprocessing on the cost of Nuclear Energy." Paper $\mathrm{CN}-43 / 432$ presented at the International Atomic Energy Agency's conference International Waste Management, Seattle, May 16-20.

Sedor et al. 1988. "Technical and Economic Aspects of Management of Radioactive Wastes on the Back-End of the Nuclear Fuel Cycles." Paper 64h presented at the American Institute of Chemical Engineers 1988 Summer National Meeting, August 2l-24, Denver. 
Semenov, B. A. 1983. "Nuclear Power in the Soviet Union." International Atomic Energy Agency Bulletin, 25(2):47-59, International Atomic Energy Agency, Vienna, June 1983.

Semenov, B. A. 1989. "Transport and Burial of Nuclear Station Radioactive Materia1." An interview of B. Semenov by a TASS correspondent regarding a report in the Latvian Publication "Atmoda" on March 13, 1989. British Broadcasting Corporation, Summary of World Broadcasts, March 24, 1989.

Shevelin, B. P., A. N. Levishchev, B. R. Borissov, and E. I. Popov. 1988. "Design Principles of the Equipment for the Back End of Nuclear Fuel Cycle. Paper $18 \mathrm{y}$ presented at the American Institute of Chemical Engineers 1988 Summer National Meeting, August 21-24, Denver.

Sinclair, C. 1987. "Civil Science in the Soviet Union--Report of NATO Symposium." A summary of a symposium of western Sovietologists and scientists held in late 1986, NATO Review, April 1987, p. 20. Advanced Study Institutes Program, NARO Scientific Affairs Division.

Sobolev, I. A., L. M. Khomchik, N. A. Mukhin, and B. D. Sokolov. 1970. "The Treatment of Solid Radioactive Wastes with a Low Level of Activity. " Paper SM-137/73 presented at the IAEA Symposium on Treatment of Medium- and LowLevel Radioactive Wastes, September 7-11, 1970, Aix-en-Provence, France.

Sobolev, I. A., A. E. Arustamov, M. I. Ozhovan, P. P. Poluektov, A. S. Polyakov, K. N. Semenov, E. M. Timofeev, S. A. Tret'yak, and V. V. Shiryaev. 1989. "Storing Strong Spent Ionizing-Radiatior Sources in Metal Matrices." Transiated from Atomnava Energiya, 66(5):340-342, May 1989. Original article submitted November 30, 1987, 1989 Plenum Publishing Corporation.

Sobolev I. A., A. S. Barinov, M. I. Ojovan (State Comittee on Atomic Energy Application, Moscow Scientific Industrial Corpcration "RADON"). 1989. "Some Aspects of Intermediate Level Wastes Safe Dispcsal in the Shallow Clay Formations." Paper presented at the IAEA International Symposium on the Safety Assessment of Radioactive Waste Repositcries, October 9-12, Paris, France.

Sombret, C. 1979. "Present Status of Techniques Used for High-Level Liquid Waste Solidification." Paper presented at the Annual Meeting of the IAEA Technical Committee on Alpha-Bearing Waste, October 1979, Cadarache, France.

Soviet Life 4/88, April 1988.

Spitsyn, V. I., B. S. Kolychev, and V. M. Sedov. 1970a. "Report on the Status of the Problem of the Treatment of Medium- and Low-Level Radioactive Wastes in the USSR." Paper SM-137/64 presented at the IAEA Symposium on Treatment of Medium-and Low-Level Radioactive Wastes, September 7-11, 1970, Aix-en-Provence, France. 
Spitsyn, V. I., F. P. Yudin, M. K. Pimenov, N. A. Rakov, V. D. Balukova, S. I. Zakharov, and S. V. Metal'nikov. 1970b. "Experience in the Operation of Installation for Underground Disposal of Liquid Radioactive Wastes." Paper SM-137/74 presented at the Symposium on Treatment of Medium- and Low-Level Radioactive Wastes, September 7-11, 1970, Aix-en-Provence, France.

Spitsyn, V. I., and V. D. Balukova. 1978. "The Scientific Basis for, and Experience with, Underground Storage of Liquid Radioactive wastes in the USSR." Paper presented at the Material's Research Society Conference on the Scientific Basis for Nuclear Waste Management, November 28 - December 1 , Boston, p. 237.

TASS. 9/25/87. "CMEA--Safe Carriage of Nuclear Waste." From news release of The Telegraph Agency of the Soviet Union, Moscow, September 25, 1987.

TASS. 7/17/89. "Reportage on Redirection of Plutonium Complex, Complex to Switch Manufacturing," LD1707111989, Moscow, July 17, 1989.

TASS. 8/12/89. "Weapons-Grade Plutonium Reactor Shut Down," Moscow TASS, 0818 GMT, August 12, 1989.

Ternovskij, I. A., G. N. Romanov, E. A. Fedorov, E. N. Teverovskij, and Yu. E. Kholina. 1989. "Radioactive Cloud Trace Formation Dynamics After the Radiation Accident in the South Urals in 1957: Migration Processes." Paper presented at the IAEA International Symposium on Recovery Operations in the Event of a Nuclear Power Plant Accident, Vienna, Austria, November 6-10, 1989.

Trabêlka, J. R., L. D. Eyman, and S. I. Auerbach. 1979. "Analysis of the 1957-58 Soviet Nuclear Accident." ORNL-5613 (PubTication No. 1445), Oak Ridge Naticnal Laboratory, Oak Ridge, Tennessee.

Varovin, I. A., A. P. Yeperin, S. A. Nikiphorov, V. G. Shevchenko, S. N. Bochkareva, Ye. A. Konstantinov, A. P. Nesterenko, V. M. Sedov, and Ye. V. Senir (VNIPIET, Leningrad). 1986. "Behavior of RBMK Spent Fue] Assemblies in Water Cooled Pools." Paper presented at the International Atomic Energy Agency Technical Committee Meeting on Behavior of Used Fuel Assemb] ies and Storage Equipment at Long-Term Storage Conditions, May 26-31, 1986, Leningrad, U.S.S.R.

Veretennikov, G. A., E. I. Ignatenko, A. A. Reznik, A. N. Litvinov, and E. P. Ananyev. 1986. "Experience with the Storage of Spent Fue 1 of VVERType Reactors." Paper presented at the International Atomic Energy Agency Technical Committee Meeting on Behavior of Irradiated Fuel Elements and Structural Materials at Long-Term Storage of INF, May 26-31, 1986, Leningrad, U.S.S.R. 
Voronkov, A. A., N. M. Kazarinov, V. P. Majorov, P. I. Fedotov, E. Dermendjiev, and G. Kaschiev. 1988. "Neutron and Gamma Scanning of WWER-440 Fuel Assemblies in the Cooling Pond of Kozloduy Nuclear Power Plant." Paper presented at the Internationa? Atomic Energy Agency's Technical Committee Meeting on Spent Fuel Surveiliance and Monitoring Methods. Reported in IAEATECDOC-461, Dctober 27-30, Vienna.

Washington Post 1989a. "Soviets Admit 1957 Nuclear Arms Plant Blast," P. A-15. Washington, D.C., 6/17/89.

Washington Post $1989 \mathrm{~b}$, as reported by the Iri-City Herald. 6/17/89. "Soviets Admit'57 Explosion Was Nuclear Accident," p. B4, Kennewick, Washington, June $17,1989$.

Washington Post $1989 \mathrm{c}$, as reported by the Iri-City Herald. 7/9/89. "Soviets to Close 2 More Reactors than Announced." Kennewick, Washington.

Washington Post 1989d, as reported by the Tri-City Herald. 7/10/89. "Soviets Talk About '57 Nuclear Disaster." Kennewick, Washington, July 10, 1989.

Washington Post 1989e, as reported by the Tri-City Herald. 11/9/89.

"Chernobyl Death Toll Raised to 250." Kennewick, Washington, November 9, 1989. 
APPENDIX A

BACKGROUND INFORMATION 


\section{A1.0 INSTITUTIONAL STRUCTURE: KEY MINISTRIES AND STATE COMMITTEES}

This section describes the Soviet organizations important to nuclear fuel cycle activities prior to the reorganization in late 1989.

The Soviet bureaucracy, with respect to nuclear energy, has had a history of being complicated and ponderous. In 1978 it was reported that at least 31 separate organizations (including seven ministries) have to sign off before and Juring operation of a Soviet nuclear power plant.

The ultimate decisions for Soviet development are made by the Communist Party hierarchy and the Supreme Soviet. Beyond them, however, the overail responsibility for nuclear development beiongs to the State Committee for the Utilization of Atomic Energy, and the Ministry of Power and Electrification (MPE) has charge of design of the core and primary reactor loop as well as of waste disposal, and various research institutes. The MPE designs, constructs and oversees the operation of nuclear and fossil plants. Its field organization, Glavatomenergo, is a general contractor for individual plant construction and operation.

At least five other ministries in 1978 were involved in nuclear power, including those for heavy power and transport machine building (they fabricate pressure vessels and steam generators under contract to Glavatomenergy), health (which provides health-related inspection), technical inspection (whose resident inspectors must give final approval on major construction items and on startup), atomic inspection (whose inspectors make annual visits to statiors preparing for startup), and standards.

Then there are the peripheral agencies, such as Atomenergoexport-Russia's nuclear export agency--and Techsnabexport, which sells Soviet enrichment services abroad. Various industrial ministries manufacture nuclear plant instrumentation and components; the Committee of Medium Machine Building repcrtedly is in charge of fuel reprocessing (Energy Daily 1978).

Information on relevant organizations in the $1980 \mathrm{~s}$, but prior to the reorganization in 1989, is given next. 


\section{Minatomenergo}

The Nuclear Power Ministry (Minatomenergo) is responsible for the development and operation of all nuclear power facilities (Leigh 1989; MacLaughlin 1989). In January 1989, Minatomenergo established a new public relations office, called the Nuclear Energy Public Information Center, within its Nuciear Information Institute (MacLachlan 1989).

GKAE

The State Committee on Utilization of Atomic Energy (GKAE), subordinate to the Nuclear Power Ministry [apparently a "branch ministry"], is responsible for the production of nuclear materials in the Soviet Union. It is also responsible for R\&D on the management of radioactive wastes (Leigh 1989; Nuclear Fuel 4/89). Its subdivision Glavatomenergo (Nuclear Energy Division) is responsible for nuclear energy programs (Nucleonics Week 10/88).

Ministry of Atomic Power Engineering

The Ministry of Atomic Power Engineering, established in July 1986, is responsible for the design and engineering of nuclear power reactors (AlJ $4 / 87)$.

GAEN

The central safety body is the Soviet State Committee on the Supervision of Nuclear Power Safety (GAEN), which was created in 1983 by combining the State Inspectorate for Nuclear Safety (part of GKAE) and the Directorate of Nuclear Power Plant Technical Safety (part of the State Committee on the Supervision of Mining Safety). GAEN is responsible for the organization of safety work carried out at nuclear power plants, including work on research reactors and nuclear power plants aboard ships. GAEN is assisted in this work by other safety and monitoring bodies (the Health Ministry, the Ministry of Home Affairs and the Hydro-meteorological Committee). GAEN coordinates the revision of existing nuclear power regulations and the development of new ones. It is also coordinating the development of a single set of regulations for nuclear power in the Comecon countries (NEI 3/89). 
GAEN's work is carried out through its central and regional bodies. It supervises the implementation of national regulations and standards for design, construction, installation and commissioning of nuclear facilities. Periodic inspections ensure that regulations are being observed at all these stages for equipment and systems. A regional inspectorate is responsible for safety and quality supervision at research reactors and aboard ship facilities. Organizations undertaking all aspects of building nuclear power plants must be approved by GAEN and are periodically inspected (NEI 3/89).

The standard technical safety documents used in the nuclear power industry are developed on the basis of research, development and operational experience. These documents also take into account the recommendations of international organizations [such as the Internationa] Atomic Energy Agency (IAEF), the International Standards Organization (ISO) and the International Commission on Radiological Protection (ICRP)] and the experience and practices of other countries. Soviet nuclear safety regulations and practices have undergone a thorough revamping following the chernobyl accident. Two main safety documents, both reviewed after Chernobyl, are: a) General Safety Regulations of Nuclear Power Plants During Design, Construction and Operation, OPB-E:2 (1982); and b) Radiation Protection Norms, NRB-76 (1976). Revisions to these documents were scheduled to be published in early 1989 (NEI 3/89).

The more specific regulations relating to the nuclear industry are also being reviewed currently, including 19 directives on:

- nuclear and radiation safety norms

- siting and distribution of nuclear power plants

- nuclear plant design, construction, installation and commissioning

- operation and decommissioning

- monitoring of environmental contamination

- protection of personnel and the public.

The review of these key safety documents will also ensure compatibility with the safety principles recently set out by the International Nuclear Safety Advisory Group of the IAEA (NEI 3/89). 
The control of safety R\&D programs also comes under the jurisdiction of GAEN. GAEN determines the direction of R\&D and assesses the results with the aim of incorporating them into regulations. It also organizes and conducts $R \& D$ to provide technical back-up to its supervisory activity, and to enable it to assess the research results of organizations in other ministries and departments. To do this, GAEN has operated a Science and Technology Center since 1987 (NEI 3/89).

Aside from seeking general improvements in safety and reliability, the principal R\&D objectives of GAEN inciude:

- assessment of component 1 ifetimes to decide between extension and decommissioning of facilities

- analysis of severe accidents and R\&D into accident prevention and mitigation

- development and adoption of quantitative probabilistic methods for safety analysis and risk assessment (NEI 3/89).

The results of this R\&D are being used to clarify regulations, particularly those relating to:

- siting and distribution of nuclear power plants

- severe accidents involving nuclear core degradation, including core melting

- environmental conditions affecting siting

- operating limits and conditions at nuclear power plants (NEI $3 / 89$ ).

Regulations on nuclear power plant safety are complemented by state standards developed and estabiished by the State Committee on Standards (Gosstandart). The system of standards ensures nuclear plant safety through establishing requirements for many components, materials, processes, and so on (Semenov 1983).

The GAEN has the right to issue writs to correct any deviations from the regulations. Where regulations have been violated and where the safety of the plants is threatened, measures may be taken, even as far as to shut down or decommission a facility. A diagram of the key nuclear safety regulatory bodies and their publications is given in Figure A.l (Semenov 1983; NEI 3/89). 


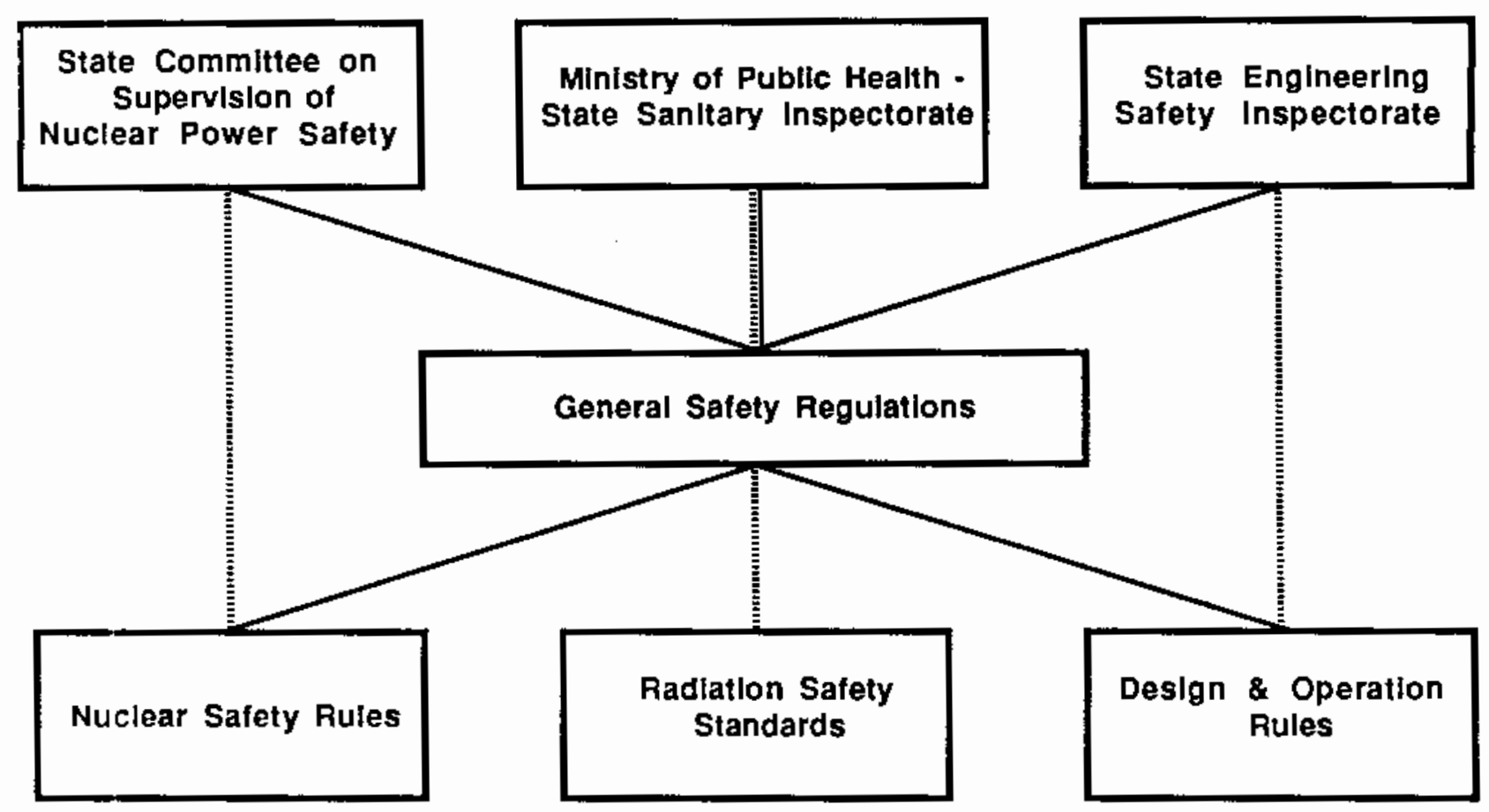

FIGURE A1.1. Nuclear Safety Regulatory Bodies and Publications in the USSR (Semenov 1983; NEI 3/89)

\section{Ministry of Public Health}

The Ministry of Public Health supervises compliance with rules and stanjards of radiation safety in design, construction, and operation of nuclear power plants through its State Sanitary Inspectorate (Semenov 1983). 


\section{A2.0 SOVIET NUCLEAR ENERGY}

This section provides some background information on Soviet nuclear power and fuel cycle policy and projections, as well as on waste management costs.

The Soviet Union is a large industrial state that bases its economic development primarily on its own mineral fuel resources. The Soviet Union cannot afford to neglect the development of nuclear power, however, because about $80 \%$ of its energy resources are concentrated in eastern regions of the country, while $75 \%$ of the population and consumers of power are concentrated in the European part of the country. The transport of fuel from the eastern parts of the Soviet Union to western regions constitutes about $40 \%$ of the shipments of the country's rail freight. Nuclear power, while substantialiy al leviating the fuel and power supply problems, is not yet able to solve them radically. The solution of these problems is possible only through substantial broadening of the sphere of utilization of nuclear power (Semenov 1983).

One solution to the USSR's energy balance that has been considered is moving as many energy-intensive production facilities as possible to the east. However, this would not solve the heating needs, which account for up to half of the organic fuel used in the country. Nuclear power has been considered to be the key concept for solving these energy issues. In the wake of the Chernobyl accident, much improvement in the quality of siting, design and construction of nuclear power plants has been a major focus (BBC 5/15/87).

The biggest issue to be faced by the new Supreme Soviet (parliament) after March 1989 will be pubTic acceptance of nuclear power (Nucleonics Week 12/88). The Soviet public has growing mistrust of Soviet scientists. As a result, the Soviets plan to enhance international cooperation in public relations (MacLach1an 1989).

The Soviet Union is beginning a major public relations campaign to promote nuclear power. To carry out this activity, it has set up a new public information center in Moscow. Some regional centers are also being established at locations of major nuclear facilities (MacLachlan 1989). There are 
also plans to start a technical society in the Soviet Union equivalent to the American Nuclear Society (NEI 4/89).

\section{A2.1 NUCLEAR POWER AND FUEL CYCLE POLICY INFORMATION}

Because less than $25 \%$ of the organic fuel resources consumed in the Soviet Union are used for electricity production, and because during the fiveyear period [i.e., 1983-1988] nuclear power plants can provide base-load consumers with electrical power only in the European part of the country, the contribution of nuclear power to the electricity supply cannot exceed 10-15\% (Semenov 1983).

Commercial nuclear power is envisioned to supply Soviet needs in several ways in addition to large central power stations. Since 1973, a nuclear heat and electricity production plant has been operating in the far northeast of the USSR, in Chukotka region, supplying the town of the diamond miners (Bil-bino) with heat and electricity. Also since 1973, the BN-350 fast reactior has been successfully supplying the 100,000 inhabitants of the town of Schevchenko with electricity and fresh water. Currently, waste-heat from the Belovarsk, Leningrad, Kursk, and Chernobyl nuclear power plants is being util zed (Semenov 1983).

Because more than $15 \%$ of organic fue] in the USSR is consumed directly in industry (including chemistry, metallurgy, etc.), the introduction of hightemperature reactors for industrial heat production, as well as to make synthetic fuel, is being considered as another possibility of widening the field of applicability of nuclear power and thus economizing conventional fuel resources (Semenov 1983).

About $20 \%$ of organic fuel consumed in the USSR is burned for central heating. The main consumers of centralized heat are again located in the European part of the country. Thus, the extension of nuclear power to centralized heating is considered as one of the most important tasks in the solution of fuel and power problems. In 1983, the first 500 MWth nuclear boiler plants (called "AST-500") were being constructed in Gorky and Voronezh, and it was expected that many more such plants will be widely used in the future (Semenov 19831. 
It was planned in 1983 that the total electric power production in the USSR would be increased to about 1500 billion kWh; nuclear plants would account for $14 \%$ of the total electricity production in the entire country by 1985 and for $24 \%$ in the European region (Semenov 1983). [However, these optimistic projections have not been realized.]

For the future, the USSR is very interested in the sodium-cooled fast breeder reactor, to make better use of its uranium reserves (Kochetkov et al. 1980). Plutonium recovered from VVER and RBMK spent fuels is planned to be recycled into fuels for FBRs or high-temperature reactors (Sedov et al. 1988).

Since the Chernobyl accident, with pressure by the public (including some party leaders and scientists) against nuclear power, the Soviets have started to scale back their plans for expansion of their nuclear power program. Following decisions made in March 1988, significant cut-backs have occurred in plans for expansion of nuclear power (MacLachlan 1989). Nuclear and other thermal energy sources are stated as becoming obsolete because of their pollution and effect on atmospheric oxygen. Nuclear power utilization has been slowed down because of its perceived danger and the problems of storing radioactive wastes. Hydroelectric power is stated as being the safest source and will be emphasized in the future (Pepeski 1989).

As of 1987, the Soviets had a nuclear power plan through the year 2000 that projected an increase of the 1987 capacity of nuclear power by severalfold, to about $30 \%$ of their total electric power. However, only about 150 GWe of total nuclear power was expected to be realized, versus the 200 GWe planned (Sedov et a1. 1988; Nuclear News 11/88).

In 1988, the Soviet five-year plan for the period 1986-1990 for increasing nuclear power was behind schedule. Out of a planned increase of 83.6 GWe, only about 60 GWe was expected to be installed. By 1988, 16 GWe of old nuclear power plant capacity should have been decommissioned, but the plants were still in operation because of the need for power and the shortage of new power plants (NEI 12/88).

The latest five-year plan for 1991-1995 is said to aim for ordering $30,000 \mathrm{MW}$ of new nuclear generating capacity, and the official goal for the 
turn of the century remains $100,000 \mathrm{MW}$, as indicated by the chairman of the State Committee for the Utilization of Atomic Energy, Alexander Protsenko (Nucleonics Week 8/89).

\section{A2.1.1 Fuel Cycle Status and Schedule}

From the very beginning, the Soviet Union planned to close the nuclear fuel cycle by reprocessing spent fuel and using the plutonium in fast reactors. Spent fuel from nuclear power plants built in other countries with the Soviet Union's assistance will be reprocessed in the USSR, so the Soviet Union can be considered as a regional center for nuclear fuel reprocessing (Semenov $1983)$.

The USSR is implementing measures to recover and recycle uranium and plutonium from VWER-1000 power reactors on an industrial scale. Several reprocessing plants are planned, each with a capacity of $1500 \mathrm{MTU} / \mathrm{yr}$, to be erected one after the other according to need. The need is currentiy determined by the plutonium requirements for the Soviet FBRs or high-temperature reactors. Recovered uranium from reprocessing of WVER-1000 fuel will be mixed with higher-enriched fuel for the RBMK reactors (Nuclear Europe 1-2/88; Sedov et al. 1988).

\section{A2.2.2 Quality Assurance and Safety}

A11 national requirements on radiation safety and environmental protection are reissued and revised regularly (GKAE 1978, p. 23). Regulatory organizations and safety codes and standards have been undergoing an upgrading procass since the mid-1970s. The main regulatory document on nuclear power plant safety in the USSR, "General regulations to ensure the safety of nuclear power plants in design, construction, and operation," was issued in 1973. This document covers all types of commercial reactors used and to be used in the USSR in the near future (WVER, RBMK, BN-FBR, and district-heating reactors). Requirements are presented in a general way, without concrete details. In most cases the "General regulations" only prescribe tasks which have to be solved to ensure safety (what must be done); they do not specify how it should be done (Semenov 1983). 
In the field of radiation safety, the basic document by which the health and inspection protection bodies are guided is "Radiation Safety Standards" (RSS-76). These standards were formulated on the basis of recommendations of the International Commission on Radiological Protection (ICRP) and establish the system of dose-limits and principles of their application. "The health regulations for design and-operation of nuclear power plants," issued in 1978, further develop and supplement the basic RSS-76 document to include siting, monitoring, and inspection problems (Semenov 1983).

Statements by Soviet speakers at international meetings in years up to 1984 all asserted that their safety codes and standards were fully compatible with the IAEA standards. Also, in discussions of technical safety issues and hypothetical accidents, the similarity of topics and terminology suggests that Soviet safety philosophy is now very similar to that of the Western countries. The Finnish influence has certainly been significant in this development: the two 440-MWe Soviet PWRs built at Loviisa were subjected to many licensing requirements of Western origin and certainity provided a very valuable exercise for the Soviet designers (Rippon 1984).

Among the safety codes introduced in the Soviet regulatory process by 1984 are those for quality assurance. The first to feel the effect of these is the component manufacturing industry. A public rap on the knuckles administered to the management of the Atommash factory at the end of 1983 was probably mostly related to the failure to meet targets for implementing quality assurance programs and completing all the associated paperwork (Rippon 1984).

In spite of discussions in the literature on safety, Soviet officials did not appear to be unduly concerned with low-level radiation exposure as of 1983. Their hot houses for growing vegetables and their fish farms use cooling water from the nuclear plants for heating. Sand beaches for the community had been built in nuclear discharge cooling ponds where fishing was encouraged. The plants were bui]t close to urban areas to supply district heating (Hurlbert 1983).

Soviet safety regulations have undergone thorough revisions since the Chernobyl accident. New reactor safety guidelines have been outlined in the 
USSR. These include 1) reducing the probability of a core melt accident to the range of $10^{-5}$ to $10^{-6}$ per reactor year, and 2) development of measures to localize the consequences of a core melt caused by external or internal forces, such that the probability of an accident with serious consequences does not exceed $10^{-7}$ per reactor year (Nuclear News 5/88). Longer and more stringent 1 icensing procedures for nuclear reactors are being encountered for satisfying the more stringent safety requirements and for backfitting improved safety features developed in 1988 into existing projects (MacLachlan 1989; NEI $3 / 89)$.

See Figure A.l on nuclear safety regulatory bodies and documents for nuclear power in the USSR.

\section{A2.2 NUCLEAR POWER COSTS}

Although the capital investment costs for nuclear power plants were 1.5 to 2 times higher than for plants using organic fuel in 1983, the cost figures for electricity production in the European part of the country (including in the Ural Mountains) showed that nuclear power plants were quite competitive. In 1979, the average cost of nuclear-generated electricity was 0.793 kopeck/kwh, whereas the average cost of electricity from conventional power plants was 0.753 kopeck/kWh (Semenov 1983). 


\section{A3.0 NUCLEAR ENERGY FACILITIES}

A number of Soviet facilities conducting research and development and industrial activities on nuclear power and related waste management activities are discussed in this section.

\section{A3.1 RESEARCH AND DEVELOPMENT FACILITIES}

\section{Kurchatov Atomic Energy Institute}

The Kurchatov Institute is the main Soviet nuclear R\&D center devoted to new reactor types other than breeders, as well as for more general enterprises such as the development of probabilistic safety analysis for Soviet-designed reactors (Nucleonics Week $2 / 89$ ).

Based on a 1963 foreign travel trip report (Seaborg et al. 1963), the Kurchatov Institute had the largest controlled thermonuclear reactor (fusion) program in the Soviet Union. The Institute also provided other laboratories in the Soviet Union with irradiation services in its reactors and electromagnetically separated isotopes for research purposes. In the past, some sep-

arated isotopes of ${ }^{239} \mathrm{Pu},{ }^{240} \mathrm{Pu}$, and ${ }^{241} \mathrm{Pu}$, as well as ${ }^{236} \mathrm{U}$, had been produced there (Seaborg et a1. 1963).

The Institute was the site of the first Soviet nuclear reactor and was where the first plutonium studies were performed. The first reactor was a natural uranium graphite pile, which came into operation early in 1946 and which was apparently still in use in 1963 (Seaborg et al. 1963).

\section{Zniitmash Laboratory}

As of 1984, the Zniitmash Materials Development Laboratory played an important role in the development of many of the processes and quality control procedures used in the Soviet component manufacturing work (Rippon 1984).

\section{Khlopin Radium Institute}

The V.G. Khlopin Radium Institute, located in Leningrad, carries out R\&D on chemical separations, fue] reprocessing technology, and geochemistry. It has a radioactive reprocessing pilot plant that has been operating since 1973, 
with a capacity of $3 \mathrm{~kg}$ uranium/d. The pilot facility uses the chop-leach head-end and PUREX solvent extraction processes (Leigh 1989).

During the Institute's formative years, it conducted work on radioactive substances in four general areas: physics, chemistry, geochemistry, and mineralogy. The Institute had the distinction of constructing the first cyciotror in Europe (Seaborg et a1. 1963).

The Institute had an extensive program in geochemistry in the 1960 s which included the study of radioactive elements in very dilute concentrations and on large scales. The migration of radioactive materials in nature was being investigated as well as the measurement of radioactive fallout (Seaborg et al. 1963).

All ventilating air and gaseous effluents generated at the Institute were to be discharged through a stack about $120 \mathrm{~m}$ high located adjacent to the research reactor building (Seaborg et al. 1963).

Liquid wastes generated at the Institute were to be concentrated by evaporation in units designed for less than 1-2 mg of entrained solids per liter. Evaporated water, if below a maximum permissible content of radioactivity, was discharged to the river. Evaporator residues and radioactive solid wastes were stored underground in double-walled stainless steel tanks, equipped with radiation monitors to detect possible leakage through the inner vessel. Lowlevel wastes above permissible concentrations were not to be discharged into the ground (Seaborg et al. 1963).

Spent fuel from the reactor at the Institute was to be shipped to another (unspecified) site for reprocessing (Seaborg et al. 1963).

\section{Research and Development Institute of Power Engineering}

The Research and Development Institute of Power Engineering in Moscow carries out R\&D on improvements in nuclear power reactor systems (Nuclear News $5 / 88)$.

\section{Physical-Technical Institute}

The Physical-Technical Institute is located at Obninsk, some 60 miles south of Moscow. One of the main directives of the Institute in the 1960s was 
the development of fast reactors. These fast reactors include: BR-1, BR-2, a $100-\mathrm{kW}$ mercury-cooled fast reactor which had been dismantled, BR-3 and BR-5 (Seaborg et al. 1963).

Obninsk was the site of the first Soviet nuclear power station, AM-1 (Atom Mir), which began operation in 1954. Its thermal power level was $30 \mathrm{MW}$, and it supplied up to $5 \mathrm{MW}$ of electricity to the local grid. Subsequently, the Institute designed and developed the superheated reactor at Beloyarsk. The Institute also designed the fast pulsed reactor at Dubna. In addition, the site had a $1500 \mathrm{kH}(\mathrm{e})$ mobile reactor in operation as we 11 as many laboratories (Seaborg et a1. 1963).

The obninsk Institute built and put into operation a $1500-\mathrm{kW}(\mathrm{e})$ mobile nuclear power plant which could be transported to and operated in remote regions of the Soviet Union. Fuel for its pressurized water reactor consisted of "highly-enriched uranium dioxide dispersed in an easily melted a1loy." The hydrogen to 235 U ratio was $250 / 1$ (Seaborg et al. 1963).

\section{Institute of Nuclear Safety}

An Institute of Nuclear Safety was being formed as of February 19B9. As with other institutes, this one will be a full-fledged research and development center as well as a center of higher education. The creation of this institute indicates the high priority put on nuclear safety by the USSR (Nucleonics Heek 2/89).

Scientific Research Institute of Atomic Reactors (NIIAR)

This Institute, located in Dimitrovgrad, played a large role in low- and intermediate-level waste research, treatment, and disposal activities. It is also the potential location for construction of a 200-MWth HTR pilot project with West Germany (Nucleonics Week 10/88; Spitsyn et al. 1970a).

Science and Technology Center

The Science and Technology Center carries out independent R\&D for the regulatory agency, Gosatomenergonadzar, to support and provide technical backup for its regulations. The center has been operating for the regulatory agency since 1987 (NEI 3/89). 


\section{A3.2 OTHER KEY SUPPORT FACILITIES}

\section{Atommash and Izhorsky Works}

The Atommash factory, near the city of Volgodonsk about $1000 \mathrm{~km}$ south of Moscow, builds complete sets of major components for nuclear power stations. The large, modern factory, partly commissioned in 1978, had the capacity to produce two reactor vessels in a year and was expected to produce six to eight per year when its current expansion program is completed. Steam generators are a'so built there (NEI 12/87b; Soviet Life 4/88).

"he Atommash plant, together with the Izhorsky Works in Leningrad, is responsible for virtually all reactor component manufacturing. It occupies a 500-hectare site. The plant was built with technical assistance from the Italian company Breda (Rippon 1984).

Lotep

The Lotep organization is responsible for the design of commercial nuclear power stations, including PWRs, RBMKs and also the BN-600 fast reactor, which (having been built for Minenergo rather than GKAE), is classified as a commercial plant. Designs were standardized there for RBMKs. Lotep was also participating in the design work for the district heating reactors, which were considered to be in a standardized form in 1984 that was ready for series building (Rippon 1984).

\section{$\underline{V / 0}$ Atomenergoexport}

V/0 Atomenergoexport is the USSR organization that provides technical assistance in nuclear technology for export to any other country. [It was originally set up for export only to CMEA countries.] The technology ranges from research facilities to commercial PWRs to development of production and manufacturing capabilities for nuclear components. It can include site surveys and selection, design, construction, supply of equipment, commissioning, training, and turn-key contracts (NEI 6/88a). Since 1983, this organization exported a number of power reactors that are operating in other CMEA countries (Semenov 1983). 


\section{Technabexport}

Technabexport is a Soviet organization under the Ministry of Medium Industrial Equipment that serves as a marketing arm for export sale of a11 nuclear goods other than power plants. It has marketed enrichment services, stable isotopes, fossil fuels and medical equipment to the U.S. (Nuclear Fuel $4 / 89)$.

\section{Interatomenergo}

An international commercial organization, Interatomenergo was founded for the cooperative manufacture and supply of equipment for nuclear power plants for the member countries of the CMEA (and recently for other countries including Yugosłavia) (Semenov 1983). 


\section{A4.0 INTERNATIONAL AGREEMENTS}

Additional background information on current USSR international agreements on nuclear fuel cycle activities is given in this section. A table summarizing the USSR's international agreements is given at the end of the section.

\section{GENERAL BACKGROUND}

The Soviets historically have had agreements with many countries in the area of nuclear cooperation. As of 1978, 25 agreements were in place (dating from .961) for nuclear research, ranging from fast breeder reactors with France and fusion and power reactors with Japan, to unspecified subjects (Duffy 1979).

\section{CMEA Countries}

"he Soviet Union has had long-standing cooperative agreements with its CMEA countries to receive uranium ore and to provide reactors and fuel, followed by return of the spent fuel to the Soviet Union. Up to 1975, the Soviet Union only allowed sales of reactors and components to the CMEA countries (Duffy 1979). The WVER is the only Soviet reactor system being adopted by the non-Soviet state members of the CMEA. The CMEA countries had a total installed capacity in 1984 nearing 5,000 MWe (Rippon 1984). By 1989, their generation capacity was 10,300 MWe, not including the USSR (AIJ 3/89, p.27). Canada

The Canadians and the Soviets signed an agreement in october 1988 to formalize a practice that has been going on for several years. In 1987 the Soviets enriched about 130 MT of Canadian uranium out of a total of 12,800 MT exported from Canada (Nuclear Fuel 10/88).

\section{Finland}

An agreement is in place for the USSR to export $600 \mathrm{MW}$-years of electricity to Finland through 1992, and 900 MW-years thereafter (Nucleonics Week $9 / 88 \mathrm{a})$. 


\section{Federal Republic of Germany}

Valery Legasov of the USSR has indicated that collaborative research under the agreement with the FRG would concentrate on high-temperature gascooled reactors in such areas as source-term and reactor physics (Nucleonics Week 4/87b).

The West German KWU and ABB signed an agreement in 0ctober 1988 to cooperate with the Nuclear Energy Division of the USSR State Committee for the Utilization of Atomic Energy (GKAE) in the design and construction of small high-temperature gas-cooled reactors (HTR). The parties foresee construction of a 200-MWth pilot HTR at the NIIAR Nuclear Research Center in Dimitrovgrad, near Ulyanovsk about $800 \mathrm{~km}$ east of Moscow. The modular-design reactor will be built on a site at the foot of a hydroelectric dam on a tributary of the Volga river. Follow-on HTR projects are foreseen for generation of process heat, process steam and electric power. The total cost of this project is estimated at about $\$ 525 \mathrm{mi} 11$ ion (Nucleonics Week 10/88).

\section{France}

In 1983, the Soviet Atommash and Izhorsky Works concluded an agreement with the French for technical cooperation in the fabrication of large nuclear components (Rippon 1984). A new agreement on nuclear cooperation was signed in January 1989. It includes safety, decommissioning and reactor design (EIA 1989a).

India

Indian and Soviet officials signed an inter-governmental agreement in November 1988 (EIA 1989a) for construction of two 1000-MW PWR reactors [VVER92 design] at Koodankulam in the southern Tamil Nadu state of India. Delays have been experienced due to disagreement over the exchange rate of the Indian rupee and the Soviet ruble. A clause in the USSR-India credit agreement gives an option to the Soviets of repayment in U.S. dollars (Nucleonics Week $10 / 89 b)$. 


\section{$\underline{\text { Italy }}$}

The Soviet Atommash plant near Volgodansk was built with technical assis tance of the Italian company, Breda (Rippon 1984). A new agreement was signed in early 1989 calling for cooperation in design and construction of all types of power plants within and outside the USSR (EIA 1989a).

Repubitic of Korea

The Soviet Union has offered to sell enrichment services at low prices to the Korean Electric Power Corporation for Korean power plants (Nuclear Fuel 2/89).

\section{United Kingdom}

British Nuclear Fuels, Limited has had a contract from 1975 to 1994 with the USSR for enrichment of about $100 \mathrm{MT} / \mathrm{yr}$ of uranium as uranium hexafluoride. A similar contract exists with the South of Scotland Electricity Board for about $350 \mathrm{MT} /$ year. The Soviet enrichment charges were reported to be significantly lower than those from western sources (Fairhall 1984).

\section{United States}

Soviet natural and enriched uranium is being imported into the U.S. by U.S. utilities. Disputed estimates are that as much as $\$ 170$ million worth of Soviet Separative Work Units (SWUs) and $\$ 140$ million worth of Soviet uranium had been sold between 1986 and the end of 1988 to five nuclear utilities (Nuclear Fuel 3/89). Most of these imports are trades through European organizations, but some are direct. The trades are claimed to be contributing to a decrease in the costs for enrichment services in the spot market (Nuclear Fuel $3 / 89)$.

Antorg Trading Company, a New York City-based Soviet firm, represents a11 Soviet trading activities in the U.S. The company is operated by Soviet citizens a dd has been incorporated in the U.S. since the 1920s. It has marketed Soviet enrichment SwUs, stable isotopes, fossil fuels, and medical equipment in the U.S. (Nuclear Fuel 4/89). 


\section{IABLE A4.1. Summary of USSR International Agreements}

\begin{tabular}{|c|c|c|}
\hline Country & ropics Covered & Date in Place \\
\hline CMEA Countries & $\begin{array}{l}\text { Supply of reactors and fuel; Reprocessing of } \\
\text { fuel; Enrichment services; Disposal of wastes. }\end{array}$ & Ongoing for several decades \\
\hline Brazil & $\begin{array}{l}\text { General agreement on reactor research, is to } \\
\text { use safety }\end{array}$ & November 24, 1989 \\
\hline \multirow[t]{2}{*}{ Canada } & $\begin{array}{l}\text { Enrichment services; Cooperation on nuclear } \\
\text { safety; Exchange of visits; Interested in } \\
\text { Underground Research Lab. }\end{array}$ & October 1988 \\
\hline & Comprehensive nuclear agreement & November 20,1989 \\
\hline Finland & $\begin{array}{l}\text { Export of nuclear energy, } 600 \mathrm{MW}-\mathrm{yr} \text { to } 1992 . \\
900 \mathrm{MH}-\mathrm{yr} \text { thereafter }\end{array}$ & Unknown \\
\hline \multirow[t]{2}{*}{ France } & Decormissioning & June 1988 \\
\hline & Safety, decommissioning, reactor design & January 1989 \\
\hline \multirow[t]{3}{*}{ Federal Republic of Germany } & Nuclear technology. HTGRs & $\begin{array}{l}\text { Ongoing for } 10 \text { years. } \\
\text { renewed in April }: 987\end{array}$ \\
\hline & Design and construction of HTGRs & October 1988 \\
\hline & $\begin{array}{l}\text { Delivery of LLW treatment facilities } \\
\text { (between Technabexport and NUKEM) }\end{array}$ & September 1988 \\
\hline India & Reactor construction & November 1988 \\
\hline Italy & Reactor design and construction & Early 1989 \\
\hline \multirow[t]{2}{*}{ United Kingdom } & $\begin{array}{l}\text { Nuclear safety, siting, construction. } \\
\text { decommissioning, regulations }\end{array}$ & March 1988 \\
\hline & Contract for enrichment with BNFL & From 1975 to 1994 \\
\hline \multirow[t]{5}{*}{ United States } & Technical exchanges, U.S. DOE and USSR GKAE & Ongoing sirce 1959 \\
\hline & $\begin{array}{l}\text { Contract for natural and enriched uranium } \\
\text { between Antorg Trading Company and U.S. } \\
\text { nuclear utilities of up to } \$ 300 \text { y over } \\
\text { the last } 2 \text { yrs. }\end{array}$ & Ongoing \\
\hline & $\begin{array}{l}\text { Nuclear safety. regulation between the } \\
\text { U.S. NRC and the USSR GKAE }\end{array}$ & April 1988 \\
\hline & $\begin{array}{l}\text { Agreement between the Kurchatov I stitute } \\
\text { and the Arnerican Nuclear Society to exchange } \\
\text { public relation information }\end{array}$ & April 1989 \\
\hline & EPA - environmental cooperation \& research & Jan. 9-12, 1990 \\
\hline
\end{tabular}




\section{TABLE A4.1. (contd)}

Orqanizations
Europear Community (EC)
Europear Nuclear Society
(ENS)
International Atomic Energy
Agency (IAEA)
World As sociation of Reactor
Reactor Jperators (WANO)

Nuciear power development, safety and research; Decenber 18. 1989 Exchange of personnel and expertise

USSR Nuciear Society (President. EP Velikhov) July 7,1989 becomes a full member of the European

Nuclear Society

Cooperation in reactor safety, review of Soviet reactors by IAEA-OSART teains

1988, increased activity iก 1989

USSR became member of WANO at its inception-

May 1989 and has one of four regional offices in Hoscow 


\section{A5.0 MINING AND MILLING OPERATIONS}

Background information on mining and milling of uranium ore for the USSR nuclear power program is given in this section.

\section{A5 . 1 URANIUM MINING}

The Soviet uranium resources are extensive. The Soviets use ion exchange and solvent extraction for purifying the ore concentrates. They convert the purified uranium mill products to uranium hexafluoride for enrichment (Laskorin et a1. 1982). Many of the Soviet uranium deposits are associated with other valuable elements. Thus, in many cases, the other elements are also recovered, thereby making the uranium recovery more economical (Laskorin et a1. 1982).

According to Soviet geologic literature, almost every type of uranjum deposit found elsewhere in the world has been found and exploited in the USSR. In addition, some of the uranjum deposits described seem to have no Western counterparts. These include deposits associated with iron ores and albitites in Precambrian metamorphic rocks and those with phosphates in clays with detrital fishbones (CIA 1985).

Uranium deposits in the Soviet Union are generally classified as either vein-type ores associated with metamorphic and intrusive-extrusive igneous rocks or hydrothermal deposits emplaced in sedimentary rocks. These two geologically distinct types, which seldom occur together, are roughly of equal importance as a uranium resource (CIA 1985).

Uranium-ore deposits in the Soviet Union are located in very different climatic and geographic zones; many of them have complicated geological, hydrological, and climatic conditions. They are found and mined at depths from a few meters to $2000 \mathrm{~m}$ and even deeper. The ore bodies are of very different shapes in different locations and of varying mineralogical content. At the present time uranium mining represents a separate and important branch of the mining industry. A combination of open pit and underground mining has been used successfully at a number of uranium deposits, with a high production rate (Laskorin et al. 1982 ). 
Geologists think that the USSR has enough uranium to meet the demands of its nuclear program, but finding and exploiting it will take time and money. Rumors in 1986 were that the Soviets were looking into the possibility of mining uranium from the B1ack Sea and in Afghanistan (Economist 5/10/86). Uranium ore was found in the mountains north of Kabul in 1983 (whereupon the Afghans were quickly relocated), and it is believed that the USSR has been secretly mining this ore. It is also believed that the Soviets were mining uraniur in some areas of the Kandahar Province in Afghanistan (BBC 6/16/84).

Uranium exploration and mining methods in the Soviet Union are essentially the same as those applied in the West. Mining methods inciude:

- underground mining to recover high-grade, vein-type deposits at a depth of $200 \mathrm{~m}$ or more

- oven pit methods applicable for low-grade ores dispersed near the sirface in large areas

- in situ leaching techniques that use sulfuric-acidified waters to exploit low-grade deposits that cannot be mined economically by open pit or underground methods (Semenov 1983; CIA 1985).

I: 1965, the USSR signed an agreement with Czechoslovakia for sole rights to all Czech uranium. However, the East German and Czech uranium deposits have al ready been heavily mined. Some estimates put $75 \%$ of the remaining Czech reserves in the sandstone deposits in the Hamr region. These deposits are reputed to be recoverable only by drijling boreholes and leaching the uraniun in situ. This practice would cause problems because the uraniumcontaining ore runs close to wells that provide Prague with its drinking water (Econgnist 5/10/86). The Soviets may be changing past agreements with respect to taking uranium from CMEA country mining operations. It was recently reported that, due to changes in commercial and strategic requirements, the Soviets will not take Czech uranium after 1991. They have been taking all of the (zech annual production, amounting to 1.8 to 2.6 mitition pounds of $\mathrm{U}_{3} \mathrm{O}_{8}$ (Nuclear Fuel 1990a).

About 10,000 workers were employed in 1987 for the mining activities in CMEA countries, which are for USSR military purposes and for nuclear power reactors ( $B B C 11 / 12 / 87$ ). Uranium ore has been mined in Hungary in the Mascek 
Hilis for USSR military purposes and for the Hungarian nuclear power program since the 1950s. The Hungarian ore and ore products for Hungarian civilian uses are shipped to the USSR where they are converted into nuclear fuel for Hungarian nuclear reactors (BBC 2/23/89).

The Soviets are aware of the limited life of their East European sources and have been stockpiling uranium for decades. Some believe the stockpile exceeds 200,000 MT. This amount is much more than the current (1986) Sovjet demand, but with its planned nuclear program [as of 1986], it could need up to 325,000 MT between 1980 and 2000 (Economist 5/10/86). Stockpiling of large amounts of uranium was also reported as early as 1977, where it was indicated that 200,000 tons had been built up since 1946. An additional 160,000200,000 MT were estimated to be added to the stockpile by 1990 (Duffy 1979). In 1990, it was reported that the Soviet Union holds inventories of at least 500 million pounds [or about 227,000 MT] of uranium, and had until recently, provided the only market for CMEA country uranium production (Nuclear Fue] 1990b).

As elsewhere in the world, uranium milling, leaching and concentration processes in the Soviet Union are carried out in proximity to mining operations to facilitate the separation of relatively small quantities of $\mathrm{U}_{3} \mathrm{O}_{8}$ from large volumes of ore. Three distinct stages in processing are:

- extraction of $\mathrm{U}_{3} \mathrm{O}_{8}$ at or near the mining site

- conversion of $\mathrm{U}_{3} \mathrm{O}_{8}$ to uranium tetrafluoride $\left(\mathrm{UF}_{4}\right)$ by reaction with fluoride

- reduction of $U_{4}$ to metal for direct use in weapons or reactor fuel or for conversion to gaseous hexafluoride $\left(U_{6}\right)$ to permit enrichment in the uranium-235 isotope (CIA 1985).

Western estimates of past USSR production of $\mathrm{U}_{3} \mathrm{O}_{8}$ (yellowcake) for nuclear power are as follows (CIA 1985):

$$
\begin{array}{ll}
1960=200 \text { MT } & 1975=1400 \text { MT } \\
1965=500 \text { MT } & 1980=2500 \text { MT } \\
1970=750 \text { MT } &
\end{array}
$$


Annual production, as reported in 1990, was estimated by the Uranium Producers of America to be at least 35 million pounds of $\mathrm{U}_{3} \mathrm{O}_{8}$ [or about 15,900 MT] (Nuclear Fuel 1990b).

\section{A5.2 URANIUM RECOVERY}

For open-pit mining, the Soviets use rotary cutters and loaders with capacities of $1,000-5,000 \mathrm{~m}^{3} / \mathrm{h}$, which includes areas where overburden is 50 $60 \mathrm{~m}^{3} / \mathrm{MT}$ of ore and higher. Hard rock is first loosened by blasting to reduce costs by $20-60 \%$. For some deep pits, costs can be reduced by $20-30 \%$ by using a combination of trucks, conveyors and rail cars, compared to by trucks alone. For underground mining, improvements have been made by a number of techniques, such as by working separately but simultaneously, different ore bodies, enlarcing the height of diggings from a previous iimit of about $45-60 \mathrm{~m}$ to $90-12 \mathrm{~cm}$, etc. Mines are worked from the lower levels first, gradually moving to upfer levels. In so doing, tailings and gangues from the upper levels are places in the excavations at lower levels (Laskorin et al. 1982).

The Soviets have found underground leaching to be an effective way of mining some low-grade uranium ores. For hydrothermally formed uranium deposits, underground leaching is primarily used in combination with undergrounc mining. This is done when first starting to mine deposits, and in mining the low-grade edges of the deposits that have been mined underground. In sone cases, underground leaching following prior blasting have raised uranitm recovery rates to $70 \%$, and even up to $90 \%$ by repeated underground blasting (Laskorin et al. 1982).

Primary recovery of uranium from mined and leached (acid or alkaline) ores is commonly done by ion exchange. The process is used with fixed-bed or with continuous moving beds. Solvent extraction using trialkylamines, tributylphosphate or di-2-ethylhexylphosphoric acid as solvents are used to recover and purify uranium from ore solutions directly or from product streams from ion es:change. Most plants use box-type mixer-settlers for the solvent extraction contactor vessels (Laskorin et al. 1982).

As of 1983, ion-exchange technology had been developed very rapidly in the Soviet Union for the uranium milling industry. It was the basic indus- 
industrial method of extracting uranium and other elements from the ores and concentrates, from natural and mine water, to obtain end-products of high purity. A method of uranium extraction from phosphoric acid solutions that form in the process of acid-leaching of uranium-bearing phosphoride rocks has been successfully used in industrial-scale operation in the Soviet Union since the late 1960s (Semenov 1983).

Sodium carbonate and bicarbonate leaching of ore in milling facilities is used for ores with high contents of acid-consuming components. This leaching is used in combination with industrial oxygen, air, and oxidation catalysts. Autoclave leaching under pressure is also carried out with carbonate leaching. Pressurized autociaves have capacities of 100-200 $\mathrm{m}^{3}$ (Laskorin et al. 1982).

The valuable components that accompany uranium are normally extracted with the uranium at the leaching stage and subsequently separated at the sorption or desorption, or extraction stages using a variety of processes. These components include molybdenum, vanadium, copper, zirconium, tantalum, niobium, gold, cesium, thorjum, scandium and rare earth elements, and phosphate fertilizers (Laskorin et al. 1982).

As of 1982, long-range R\&D for milling processing was aimed at the use of more effective super solvent extraction agents, which include phosphinoxides, phosphoric acid amides, cyclotriphosphasotrienes, and crown ethers. Iria] full-scale production testing was planned. Also, impregnated solid extraction agents were being studied for uranium extraction (Laskorin et al. 1982).

The Soviets found that low-grade deposits could be mined with a $100-200 \%$ reduction in capital outlays and a $200 \%$ improvement in labor productivity. The use of autoclaves for high-pressure and hich-temperature leaching of mined ores was stated as paying for itself in 1.5 to 2 years (Laskorin et a1. 1982).

The budget for uranium mining in Hungary is 2,000 million Hungarian forints/year (BBC 2/23/89). 


\section{A6.0 URANIUM CONYERSION, ENRICHMENT AND FUEL FABRICATION}

\section{Background information on uranium conversion, enrichment and fuel fabrication for the USSR nuclear power program is given in this section.}

\section{A6.1 URANIUM CONVERSION}

In the second half of the 1940s, industrial facilities for the production of uranium hexafluoride and its subsequent enrichment by gaseous diffusion were developed and built in the Soviet Union within a very short time period. The technology of hexafluoride production developed in parallel with that of nuclear power and as of 1983 had reached a high degree of sophistication (Semencv 1983). As of 1983, the front end of the Soviet nuclear fuel cycle included a step to convert the milled uranium product into uranium tetrafluorice. The next step [apparently in another facility] is conversion to uranium hexafluoride (Sedov et al. 1983).

Since 1973, the USSR has been offering uranium purification, conversion and enrichment services to other countries, including western countries (Semenov 1989).

Uranium hexafluoride that is received from or delivered to other countries is transported in thick-walled containers made from a special alloy. These containers have been endorsed by the competent bodies in the respective countres and meet all the IAEA transportation standards. Since 1974, there has not been one single accident in the USSR involving containers holding natura or enriched uranium hexafluoride (Semenov 1989). Uranium hexafluoride in containers that hold 15 MT from the United Kingdom is transported on Soviet ships and is received at Riga, Latvia. From there it is transported to the Soviet enrichment facility at an unknown location (Fairhall 1984).

\section{A6.2 URANIUM ENRICHMENT}

The Soviet Union has reserved for export about half of the output of its 10 million SWU/yr centrifuge enrichment enterprise, according to Boris Nikipelov, first deputy minister of the Ministry of Atomic Energy \& Industry. 
Nikipelov, interviewed in the November issue of Nuexco's Monthly Report, al so said that the Soviets are prepared to sell SwU contained in Soviet-enriched uranium. Nikipelov said current Sovjet annual sales are about 2 million SwU. The Soviet official said that Techsnabexport, the foreign trade organization within the Ministry of Atomc Energy, will "continue competing aggressively to sell all of our available output, but without sacrificing favorable prices" (Nuclear Fuel 11/89). The estimated availability to western countries by the Energy Information Administration is 3 MSWU (EIA 1989b).

Soviet officials have told Western experts that the USSR has a total centrifuge capacity of about 10 million SwU/yr, consisting of modular centrifuge facilities with a capacity of about 1 milition SWU/yr each. These, Western officials believe, are located at least three sites in the USSR. The piants are believed to have replaced almost all of the Soviet's gaseous diffusion capacity, although one of five diffusion plants may still be operating. Alexander Chernov, deputy general director of Techsnabexport, Moscow, stated that the USSR's first enrichment facility was a gaseous diffusion plant put into operation in 1949. This plant, he said, was similar to a facility bujlt in the U.S. four years earlier. He indicated that the first pilot centrifuge plant was built in 1952, the first industrial pilot plant [centrifuge] went into operation on October 4, 1957--the same day as the USSR launched the Sputnik satellite, and the first full-fledged industrial centrifuge unit was put into operation in 1959, with the full-scale plant, based on three modules, going on line between 1962 and 1964 (Nuclear Fuel 10/89c).

While the USSR's centrifuge technology was originally developed for the Soviet weapons program, Chernov confirmed recent statements from other Soviet officials that the country's centrifuge plants have been placed at the disposal of Techsnabexport for enrichment for power reactors. Over the last several years, Chernov said, Techsnabexport has offered one- to three-year enrichment contracts in the world market, as well as spot contracts and one shipping contract. Beginning in 1988 he said, Techsnabexport offered enriched uranium produced from Soviet material (Nuclear Fuel 10/89c). Techsnabexport recently entered into agreements under which General Electric and Westinghouse 
are each storing about 400,000 SWU contained in 100,000 kilograms of enriched uranium products at its fuel fabrication plants (Nuclear Fuel 10/89b).

Several alternatives to the gaseous diffusion method of uranium enrichment have received attention in the USSR, including experimentation with photochemical technology using lasers (CIA 1985). According to a number of knowledgeable U.S. government and industry sources, the Soviet Union could have as much, if not more, enrichment capacity as the U.S.--capacity not only from gaseous diffusion plants, but also from more modern centrifuge facilities. Because of this capacity, the Soviets may be able to offer as much as 10-million SWU for sale to the west, more than triple the amount commonly believed to be the Soviet limit for Western sales. A policy decision to stop high-e:iriched uranium production for weapons and the recent cancellations of reactors probably has freed up capacity, according to one analyst, so that the Soviets have at least 5- to 6-million SWU for sale to western countries (Nuclear Fuel 6/89).

Gas centrifuge enrichment production capacity is said to be modern and highly efficient, according to Nuexco, in its 1988 Annual Review. After World War II, the Soviets captured a group of German scientists, including Gernot Zippe, considered by many the father of centrifuge isotope separation, who continued work in the Soviet Union on centrifuge development. (Zippe, after being released by the Soviets, went on to make contributions to both the U.S. and Urenco centrifuge efforts.) But according to one U.S. source, the Soviets have several warehouses full of centrifuge machines and would be willing to sel] them to a bona fide company. Another source, however, said his firm was told by Soviet representatives that "there are no current plans to offer (the machines) to the West" (Nuclear Fuel 6/89).

As of about 1982, the USSR had an operational enrichment capacity of about $10 \mathrm{MSWU} / \mathrm{yr}$ in gaseous diffusion plant(s) at unknown location(s) in Siberia, with no projected capacity change by 1990 (IAEA 1987). British Nuclear Fuels LTD sources know very little about the Soviet enrichment facilities, but they believe the facilities have capacities that are several times the Soviet requirements. The capacities are presumably dictated by the needs of both nuclear power and military programs. Available information suggests 
that foreign contracts up to 1990 wi11 account for about $75 \%$ of Soviet enrichment output [this may mean $75 \%$ of the excess output] as of 1984 (Fairhal] 1984). In 1977, it was reported that $55 \%$ of the European communities' contracted enrichment services were supplied by the Soviet Union (Duffy 1979).

\section{A6.3 FUEL FABRICATIDN}

After fuel reprocessing, the recovered uranyl nitrate hexahydrate is converted to uranium hexafluoride for enrichment before fabrication into new fuel elements (Sedov et al. 1988). In Soviet fuel fabrication plants, welding and filling of the fuel tubes with pellets is fully automated. Ultrasonic checks on weld quality, monitoring of fuel-rod integrity and of the rods' geometrical parameters, density, etc., are all highly mechanized. The high level of technology practically el iminated fuel-element failures in the initial period of operation, when fabrication defects are usually revealed. Fuel pin failure, resulting in the release of fission products into the coolant, has become a very rare phenomenon, and the number of failed fuel rods was less than $0.2 \%$ as of 1983 (Semenov 1983).

Recovered plutonium oxide will be used for preparing fuel for fast- or high-temperature reactors (Sedov et a1. 1988). 


\section{A7.0 NUCLEAR REACTOR SYSTEMS}

Background information on nuclear reactor systems for USSR nuclear power ocean vessel propulsion, research, and defense activities is given in this section.

\section{A7.1 GENERAL INFORMATION}

TJ select the types of reactors that would be most appropriate and econonic for the Soviet Union, the State Committee for the Utilization of Atomic Energy set up a research and development program on different types of nuclear power reactors: PWR and BWR (vessel type), channe]-type BWRs, organicmoderated and cooled reactors, etc. In the course of this work some types of power "eactors were abandoned before they reached the prototype stage, such as reactors with organic moderators and coolants. Work on organic-moderated reactors did result, however, in the construction during 1963 of a transportable nuclear power plant that had an electrical capacity of $750 \mathrm{~kW}$. Research and development on a number of thermal nuclear power reactor concepts resulted in the construction of three different prototype units: the first and second units of Novovoronezh with PWRs; the first and second units of Beloyarsk with channel-type reactors; and the Dimitrovograd BWR (Semenov 1983).

Since the Chernobyl accident, pressure by the public (including some party leaders and scientists) against nuclear power has forced the Soviets to scale back their plans for expansion of nuclear power. There is now almost no site in the USSR where the population is not opposed to nuclear power (NEI 4/89). Following decisions made in March 1988, construction was stopped on 13 nuclear reactor units; and eight planned units, plus four more units for cogeneration, were abandoned altogether. The listing of these units is given in subsection A7.11. In addition, commissioning of nuclear power projects that were under way when the Chernoby? accident occurred have been delayed by longer and more stringent licensing procedures and by backfitting units with safety improvements developed in 1988 (MacLachlan 1989).

The projections for instalied nuclear capacity in the USSR by the year 2000 have recently been scaled back from 150,000 to 100,000 MWe. However, 
even increasing the current capacity of about 35,000 to 100,000 MWe will be difficult to achieve (MacLachlan 1989).

The USSR is counting on "advanced WVERs" (i.e., safer and ultimately more economical VVERs) to provide the mainline of nuclear power to the year 2000. HTGRs and FBRs are under study, but they are not expected to provide a significant part of the nuclear power in the near future (MacLachian 1989).

Early on in its nuclear power program, the USSR paid special attention to the development of fast breeder reactors. The first experimental reactor, with plutonium fuel, went into operation in 1955. The capacities of experimental reactors which then followed have been successively increased (Semenov 1983).

The Soviets have maintained serious intentions to implement nuclear district-heating stations, of which several versions are under consideration. As of 1980, for instance, four units of the smallest RBMK version of 12 MWe each, located beyond the Arctic Circle in Bilibino (in northeast Siberia), had been supplying local mining operations and the workers' settlement (including hothouses) with electricity and heat for many years. Besides these heating units, other nuclear district-heating plants of 500 Mwth are based on the WVER design and operated at low reactor pressure (about 16 atmospheres) and with output temperatures of on $7 y 200^{\circ} \mathrm{C}$. These nuclear heating units were planned to be installed in the immediate neighborhood of urban centers. In 1980, there were many other projects for pure district-heating or cogeneration nuclear power plants (Feuz 1980).

As of 1986, two district heating units of 500 Mwth each were nearing completion in Gorky and Voronezh, cities of a half-million inhabitants. A peer group design review of the Gorky AST-500 district heating unit was done in 1989 under the auspices of the International Atomic Energy Agency (NEI $4 / 89)$.

As reported in 1986, nuclear cogeneration units of 940 and 1000 Mwe were being built in Odessa (two units), Volvograd, Kharkov, and Minsk, with half of 
their capacity reserved for electricity production and the other half for heat production (Nucleonics Week 1/86). These units, however, have since been cancelled or postponed.

Outside the Soviet Union in other CMEA countries, the PWR is the only system being adopted (Rippon 1984). The other CMEA countries had a total installed capacity at the end of 1989 of 10,300 MWe, not including the USSR (AIJ $3 / 89$, p. 27).

\section{A7.2 VVER REACTORS}

The VVER is a further development of the reactors built in the late 1950 s to power the "Lenin" nuclear icebreaker. Initially, the Novo-Voronezh nuclear power plant was equipped with 210 MWe and 365 MWe WVER units. Then the 440 MWe units were introduced which became the basis for the standard designs of the first, fully industrial generation of Soviet nuclear power plants equipped with PWRs. These were planned to be built in large numbers, mainly in the other CMEA countries. The change to the WVER-1000 in the early 1980s was intended primarily to cut construction costs and improve operational efficiency, in order to achieve lower electricity production costs (Feuz 1980).

At the beginning of 1983, 27 VVER-type power reactors were in operation throughout the world, including 13 units in Bulgaria, Czechoslovakia, Finland, the German Democratic Republic, and Hungary. An example of their base-load operational data for some Soviet WVER is shown in Table A7.1 (Semenov 1983; IAEA 1988).

Some of these units were constructed in the far north (e.g., at Kolsk). The Armenian nuclear power plant was designed to withstand for seismic conditions and was, therefore, more expensive. However, capital costs of Soviet VVERs did not increase as did those for PWR costs in the west during the same period (Semenov 1983).

On the basis of the technological achievements in fuel fabrication, the operating parameters for VVER fue? had been further upgraded as of 1984 (Semenov 1983; Rippon 1984). In 1977, average burnup in the WVE-440 reactors 
TABLE A7.1. Performance of Selected Soviet VVERs Through 1987

\begin{tabular}{|c|c|c|c|c|c|}
\hline Power Plant & Unit & $\begin{array}{l}\text { Installed } \\
\text { Capacity } \\
\text { (Mwe) }\end{array}$ & $\begin{array}{c}\text { Capital cost } \\
\text { (ruble } / \mathrm{kW} \text { ) }\end{array}$ & $\begin{array}{c}\text { Startup Date/ } \\
\text { Cumulative } \\
\text { Electricity } \\
\text { Production, } \\
\text { GWhe } \\
\text { (through 1987) }\end{array}$ & $\begin{array}{c}\text { Lifetime } \\
\text { Average } \\
\text { Load-Factor } \\
\text { (through 1987) }\end{array}$ \\
\hline Novovoronezh & $\begin{array}{r}\text { I } \\
\text { II } \\
\text { II } \\
\text { IV } \\
\text { V }\end{array}$ & $\begin{array}{r}210 \\
365 \\
440 \\
440 \\
1,000\end{array}$ & $\begin{array}{l}326 \\
256 \\
200 \\
200 \\
308\end{array}$ & $\begin{array}{l}1964 /-- \\
1969 / 45.5 \\
1971 / 44.2 \\
1972 / 45.6 \\
1981 / 45.9\end{array}$ & $\begin{array}{l}0 . \\
0.74 \\
0.64 \\
0.89 \\
0.81\end{array}$ \\
\hline $\begin{array}{l}\text { Kolsk } \\
\text { (or Kola) }\end{array}$ & II & $\begin{array}{l}440 \\
440\end{array}$ & $\begin{array}{l}263 \\
263\end{array}$ & $\begin{array}{l}1973 / 40.7 \\
1974 / 38.7\end{array}$ & $\begin{array}{l}0.85 \\
0.87\end{array}$ \\
\hline Armenian & $\begin{array}{r}\text { I } \\
\text { II }\end{array}$ & $\begin{array}{l}408 \\
408 \\
\end{array}$ & $\begin{array}{l}327 \\
327 \\
\end{array}$ & $\begin{array}{l}1976 / 22.6 \\
1979 / 19.6 \\
\end{array}$ & $\begin{array}{l}0.59 \\
0.74 \\
\end{array}$ \\
\hline TOTALS & 9 & 4,150 & 280 (average) & & \\
\hline
\end{tabular}

was about 28 GWd/MT; for the WWER-1000 reactors, burnup averaged about $41 \mathrm{GWd} / M T$ (Kondratyev et a1. 1977). More recent information gives the average fuel burnup of WWER-440 reactors as $33.2 \mathrm{GWd} / \mathrm{MT}$ (Ignatenko et a]. 1986) and WWER-1000 reactors as 42.7 GWd/MT (DOE 1989). Fue1 for WWER-1000 reactors, which was originally designed for a two-year regime with a maximum burnup of $40 \mathrm{GWd} / \mathrm{MT}$ of uranium, was designed in 1983 for a three-year cycle of operation, with a burnup of 55 GWd/MT of uranium. Starting in 1983, the WVER-1000 reactors were planned to operate on a three-year cycle (Semenov 1983; Rippon 1984).

Two WVERs to be used for district heating were nearing commissioning at Gorky, about $300 \mathrm{~km}$ east of Moscow, as of early 1989. The two 500-MWth reactor units, called AST-500, are considered "super-safe," with a doublereactor vessel and a third-cooling circuit. The Soviets have asked the IAEA to review the safety of these units. Other AST units are under construction or planned at three locations: a district heating station is nearing completion in Voronezh in southern Russia; one is under construction at Arkhangelsk on the white Sea in northern Siberia; and siting surveys are being completed 
for a third unit at Khabarovsk in the Soviet far east on the Amur River just across the border from Chinese Manchuria (MacLachlan 1989).

\section{A7.3 RBMK REACTORS}

The development of channel-type, iight-water-cooled, graphite-moderated reactors (LWGRS) began with the commissioning of the first nuclear power plant in Obrinsk in 1954 (Semenov 1983). Between 1958 and 1963, several LWGR plutoniusil production reactors were built in Siberia which also were reported to provicle electric generating capacity (Rippon 1984). Commissioning of the first and second units of Beloyarsk, with capacities of 100 and $200 \mathrm{MW}$, followed (Semenov 19B3).

The next stage in the development of channel-type reactors in the USSR was the boiling-water, high-power reactor designated as the RBMK-1000. It was noted by Semenov that the design feature of having more than 1000 individual primary circuits increased the safety of the reactor system to the extent that a ser:ous loss-of-coolant accident "is practically impossible" (Semenov 1983). The successful operation of RBMK-1000 reactors at nominal power, and the reserve capacity found in their design (without changing the size and number of fuel assemblies), have made it possible to increase the power of each process channel or fuel assembly by a factor of 1.5. The average construction time "or two $1000 \mathrm{MW}$-units was 7.68 years (Semenov 1983). The average fuel burn-ı:p for an RBMK-1000 reactor in 1986 was 15.5-22.3 GWd/MT (Kondratyev et al. 1986).

\section{A7.4 FBR REACTORS}

The USSR is very interested in the sodium-cooled fast breeder reactor to make better use of its uranium reserves. As of 1980, the main stages of the fast reactor program in the USSR were characterized as follows (Kochetkov et a 1, 1980):

1948-1958 Scientific research and substantiation of principal technological solutions 
1958-1969 Creation of large experimental rigs and facilities in order to obtain and verify main physical data and prerequisites, to gain technical know-how and operating experience with liquid metal coolant, and to choose and substantiate structural and fuel materiais.

1969-1980 Deve1opment and construction of large prototype plants, creation of the base for the development and fabrication of commercial size reactor components.

Development and construction of advanced prototype fast reactors for their serial introduction.

solution of fuel cycle problems (i.e., reprocessing and fabrication of recycle fuels).

Important FBR milestones completed over 30 years up to 1980 were:

1955, Obninsk - Construction of the BR-1 experimental fast fue 7 assembly and the first substantiation of the breeding concept

1958, Obninsk - Construction of the BR-5 reactor and first experience gained with the operation of the plutonium dioxide-based core and with radioactive liquid. metal coolant

1961 and 1971,

Obninsk- 1961: BFS-microtron; 1971: BFS-2, construction of the experimental physical complex to mock-up the power fast reactor cores and to study their physical characteristics

1969

Dimitrovgrad - Construction of the BOR-60 reactor, which allowed for intensification of studies on reactor materials, to test tentative fuel and absorbing subassemblies as well as steam generators of different types

1973 ,

Shevchenko - Construction of the first industrial loop-type reactor of 1000 Mwth power, the BN-350; first industrial experience gained with the development, fabrication and operation of large fast reactor components and the core

1980 ,

Zarechny - Startup of a larger industrial power poo]-type reactor, the BN-600, of 1400 MWth (Kochetkov et a1. 1980). 
The BN-350 was built at Shevchenko, on the Caspian Sea. Besides an electricity-generating capacity of $150 \mathrm{MWe}$, the facility was also designed for the desalination of $120,000 \mathrm{~m}^{3}$ of seawater daily. A serious stean generator accident occurred in 1974, and since then, the installation could be operated at only $65 \%$ of its initially-planned thermal capacity. The BN-600 started power operation in April 1980, and in December 1981 the reactor was brought up to its nominal power of $1470 \mathrm{MWth}$. The maximum burn-up of fuel reached $7 \%$. As of 1983, the next generation of fast breeder reactors, $\mathrm{BN}-800$ and $\mathrm{BN}-1600$, was being designed for commercial introduction (Semenov 1983).

The Soviet Union is proceeding with plans for a series of batch-produced $\mathrm{BN}-800$ sodium-cooled fast reactors to be deployed in the 1990 s. The existing oxide fuel (used in the smaller fast reactors) is to be used, although a core containing both oxide and metal fuel elements is under consideration (NEI 10/883).

The Soviets have made some basic decisions on the steam generating section of the planned successor to the BN-800 FBR, the BN-1600 FBR. This reactor will be a pool-type plant with four heat output loops located in a 19-meter-diameter vessel (NEI 6/88b).

More information on the USSR fast reactors was given in the recent NRDC report. At the Kyshtym site, they mentioned that three BN-800 liquid metal fast breeder reactor (LMFBR) power plants, the "South Urals Power Station," have been proposed. One or two of the reactor foundations are lajd; however, construction is delayed pending review of the entire program. The $\mathrm{BN}-1600$ is in the design stage; construction is unlikely before 2020 . The breecer program is delayed by two concerns. The first concerns the possibility of a runaway chain reaction during an overheating accident, and the secord, a lack of need. Research is expected to be completed "in the near future," on mixed-oxide (MOX) fuel for recycle in existing thermal power reactors, leading to construction of a MOX fuel plant and possible commercial export of MOX fuel to other countries (NRDC 1989). 


\section{A7.5 OCEAN VESSELS}

The first nuclear-powered ice-breaker in the world, the Lenin, was constructed in 1959 and celebrated its twentieth anniversary of operation in the Arctic ice in December 1979. The next ship in the series of nuclearpowered ice-breakers, the Arktika, went into operation in 1974; and in 1977 the ice-breaker, Sibir, started work. The latter two ships are equipped with a standard 75,000-horsepower nuclear power installation, and their technical performance was claimed to be better than those of the ice-breaker, Lenin. The Soviet Union is also considering the use of nuclear-powered carrier-ships in Arctic regions (Semenov 1983).

A fifth nuclear-powered icebreaking ship, the Sevmorput, was commissioned in November 1988. The Sevmorput is designed to break ice of moderate thickness. Two more nuclear-powered icebreakers are due to come into service shortly (Nuclear News 1/89).

\section{A7.6 RESEARCH REACTORS}

There are over 60 research reactors [Table A.7.2 lists those known as of 1963] constructed in the USSR, of which about 36 are for civilian uses. Most are operated by the research institutes. A wide variety of research reactor types is used. Dispersion-type of fuel elements are used in 31 of the reactors, and assemblies with tubular rods are used in 27 research reactors. Fue 1 enrichment levels range from 10-90\% uranium-235. Research reactor power levels range from $1 \mathrm{~kW}-20 \mathrm{MW}$ or more. Seven civilian reactors are pulsed reactors (Kritsky et al. 1988).

\section{A7.7 DEFENSE REACTORS}

Only very recently has there been any publicly available information on the Soviet defense reactors, other than the brief mention as indicated at the beginning of Section A7.3. In July 1989, some information was released on the reactors at Kyshtym. The Soviet government decided to shut down all five nuclear reactors producing plutonium for nuclear weapons at the Kyshtym Industrial Complex, a top-secret military center in the Urals, idling two more reactors than were announced originally by Soviet President Mikhail Gorbachev 
in the spring of 1989 in London. The decision was revealed by Boris $V$. Brokhovich, the center's director. He said in an interview that two of the site's reactors are shut down now, a third will be closed in August 1989, and the remaining two will cease operation in 1991 (Washington Post 1989c; TASS $8 / 12 / 89)$.

Additional information on production reactors was given in a recent fact sheet prepared by the NRDC. At the Kyshtym site visit, they visited the first Soviet plutonium production reactor, A-Reactor called "Anotchka," or "Little Anna" (in English), and the source of plutonium for the first Soviet atomic bomb called "Joe-1" in the West. Construction began around 1946 and initial operation started June 19, 1948. Shutdown occurred in 1987, after 39 years of operation, and it is now being dismantled. The initial power level was 100 Mwth and the final power level was 500 Mwth. Cooling water from a nearby lake was pumped directly through the core, with an average $70^{\circ} \mathrm{C}$ discharge temperature into the lake and a maximum discharge temperature of $80-85^{\circ} \mathrm{C}$. The reactor is being dismantled in three stages, reported as follows: first stage-shutdown, fuel unloaded; second stage--up to five years, includes dismantling of control and operating system, filling empty spaces with concrete; and third stage--20-25 years, no activity, after which a decision will be made to bury on the site or remove. The B-Reactor at the Kyshtym site was reported to be a dual-purpose reactor for fuel rod research for RBMK's and plutonium production. It was scheduled for shutdown on August 8, 1987, and is now being dismantled. Its power leve] was $65 \mathrm{Mw}$ th and was more or less the same throughout its $h$ :story. The third reactor had an initial power level of 100 MWth and a final power level of $500 \mathrm{Mwth}$, and was scheduled for shutdown in August 1989. The fourth and fifth reactors are in operation. They were built more recently, operate at a higher power level, and are located in a separate area of the complex. The NRDC also reported other production reactor sites at Tomsk and Krasnoyarsk (NRDC 1989). It has been reported that the Kyshtym site will have a new manufacturing mission, such as for producing Tightguides (TASS $7 / 17 / 89)$. 


\section{A7.8 NUCLEAR REACTOR RESEARCH AND DEVELOPMENT}

The Soviets are working on enhanced safety features for RBMK and WVER reactors. This is being done by improving the safety features of projects currently in the planning and construction stages, as well as with entirely new reactor engineering systems (Nuclear News 5/88).

An enhanced safety version of the RBMK channel reactor known as the UKR is being developed from the 1500-MWe RBMK-type now operating at Ignalina. The improvements in the UKR compared with the current RBMK reactors are: 1) eliminating the RBMK's positive void coefficient by reducing the lattice pitch of the fuel and increasing the uranium:graphite ratio, 2) use of higher-enriched uranium without the need for additional fixed absorbers in the core, 3) use of an accelerated insertion mechanism for the control and protection rods, 4) limiting the power rating of the fuel to $370 \mathrm{H} / \mathrm{cm}$ and the maximum graphite temperature to less than $\left.750^{\circ} \mathrm{C}, 5\right)$ reducing the size and number of the feedwater and steam collection headers, 6) use of three 50\% emergency core cooling trains, 7) use of a new decay heat removal system supplied from a water reservoir built into the roof of the reactor building, 8) use of a cooledbase slab below the reactor, and 9) installing extra hafnium detectors in the central tubes of fuel bundles for better reactor control. Design work has been reported on a further development of the channel-type reactor that would have an output of 2400 MWe derived from 1920 boiling water channels with zirconium-clad fuel and 960 channels with steel-clad fuel for superheating steam from the bolling channels. Superheating channels of this type have beer demonstrated in one of the Beloyarsk reactors. Parallel development work reported at Electrosila is directed toward a 1200-Mwe turbogenerator to operate at a speed of 3000 revolutions/minute, which would, presumably, be able to make good use of the improved steam conditions from the superheattype reactors (Nuclear News 5/88; Adamov 1988).

Additionally, work was reported to be in progress at the Kurchatov Institute on a "super-safe" graphite-moderated channel reactor (MacLachlan 1989).

The Soviets are studying two advanced concepts for WVERs. A project called VVER-88 was initiated in 1988 (with contributions by West Germany) to 
demonstrate several of the safety features (Adamov 1988). The first concept, part of Project WVER-88, incorporates a passive emergency flooding system. The concept is intended to provide prolonged retention of a molten core in contalinment through the use of boric acid injection, reinforced concrete founclation and filtered venting. The first complete WVER-88 will be commissioned about 1994 at Khmelnitsy-5 in the Ukraine. The second WVER concept may include additional passive flooding and a steel envelope inside containment to allow for natural circulation air cooling. These enhancements include: 1) a passive system for flooding the reactor basement with boric acid, 2) an increase in the thickness of concrete below the reactor vessel, 3) a containment venting system with $99.9 \%$ efficiency removal of iodine and cesium, and 4) a possible concept that uses a second concrete shell around the primary steel containment, with provision for natural circulation air cooling in the annulus (Nuclear News 5/88; NEI 6/88b; MacLachlan 1989).

Work has begun on further improvements to the VVER beyond those developed in Project-WVER-88. Development of the new concept, called WVER-92, will continue for the next five to six years. This concept will feature a radically simplified design, passive safety and unproved diagnostics. The other comecon countries are joining the Soviets on these studies, and the Soviets are looking to the West for other "partners" (e.g., France is a prime candidate) (MacLachlan 1989; NEI 4/89).

Design of a VVER-1800 reactor, an upgraded, more economical, and safer version of the VVER-1000 reactor, was started in the USSR in 1987. The new version will have a planned reactor 1 ife of 70 years and four coolant loops. Major safety improvements will be: 1) decrease of power peaking in the core, 2) increased fuel-cladding gap conductivity, 3) more optimal core configurations including refueling one-quarter of the fuel each year, 4) use of zirconiun instead of stainless steel in fuel spacer grids and guide tubes, 5) low leakange cores, 6) long radiation 1 ife of the reactor vessel, and 7) more reliable control and protection systems (Nucleonics Week 11/87).

"he Soviets are studying three advanced concepts for HTGRs. The first advanced modular HTGR incorporates a steam generator and a heat exchanger along side the reactor vesse]; the second concept incorporates the steam 
generator integral with and above the reactor; and the third concept incorporates more than one reactor-steam generator in an integral multi-cavity, prestressed concrete pressure vessel (NEI 6/88b).

The Germans and Soviets plan on construction of a 200 - to 300-MWth pilot HTR at the NIIAR Nuclear Research Center in Dimitrovgrad, near Ulyanovsk about $800 \mathrm{~km}$ east of Moscow. The modular-design reactor will be built on a site at the foot of a hydroelectric dam on a tributary of the Volga river, and is expected to be completed in 1996. Follow-on HTR projects are foreseen for generation of process heat, process stearn and electric power. The total cost of this project is estimated at about $\$ 525 \mathrm{million}$. The pebble-bed reactor uses graphite pebbles containing about $10 \%$ uranium-235, and comes close to being qualified as an inherently safe reactor. The reactor will operate at $700-750^{\circ} \mathrm{C}$, then may be backfitted to operate as high as $950^{\circ} \mathrm{C}$ to enable coal gasification and production of process heat for the Soviet chemical industry (Nucleonics Week 10/88; Radwaste News 10/27/88).

The USSR is turning away from traditional fast-breeding FBRs to smaller, simpler FBR designs under study at the Kurchatov and Obninsk research centers. The earlier BN-800 FBR project at Byeloyarsk has evidently been postponed indefinitely (MacLach1an 1989).

\section{A7.9 REACTOR COST INFORMATION}

The initial cost of the Novovoronezh nuclear power project, including the first 210-M unit completed in 1964, and general facilities common to the first two units, was given as (Seaborg et a1. 1963):

Power plant $\quad 50$ million rubles

Site preparation $10 \mathrm{million}$ rubles

Town

14 million rubles

Total $\quad 74$ million rubles

The plant was expected to operate for the equivalent of $6000 \mathrm{hr} /$ year at full load. The expected cost of power from the first unit was 0.8 kopecks/ kWh; this includes depreciation of the entire investment of 74 million rubles over a 20-year period, but carries no interest charge. [No interest is 
charged on domestic projects; $2.5 \%$ per year is charged abroad.] From these figures, the capital component of power cost would be 0.33 kopecks/kWh, leaving 0.47 kopecks/kWh for fuel and operating costs (Seaborg et al. 1963).

The cost of power from the second unit at Novovoronezh was expected to be 0.60 kopecks $/$ kWh. The lower figure is due to the higher capacity and costs for facilities common to both units will have been charged to the first unit (Seaborg et al. 1963).

The Politburo of the USSR has stated that the accident recovery program for the Chernobyl accident cost U.S. $\$ 7$ billion, and the replacement power costs were an additional U.S. $\$ 7$ billion. The recovery costs include U.S. $\$ 1.6$ billion for compensation and additional costs for construction of houses and apartments for the 135,000 evacuees (Nucleonics Week $1 / 88$ ).

A common fund to finance the decommissioning of Soviet and Comecon's nuclear power plants has been set up. A multinational economic association will be created to manage the fund (NEI 12/87a).

Electricity costs from breeder reactors have been reported to be 2.5 times higher than from other nuclear power plants (NRDC 1989).

\section{A7.10 REACTOR SAFETY AND QUALITY ASSURANCE}

Documents such as codes, guides, rules and procedures develop Soviet reactor safety requirements further and specify them more concretely than the "General Regulations." They also establish the basis for activities of designers and corresponding supervisory bodies. One of the main documents in the field of engineering safety is "Regulations for Design and Safe Operation of Cormonents for Nuclear Power Plants, Test and Research Reactors, and Insta lations" (Semenov 1983).

"he system of Soviet regulatory documents on nuclear power plant safety is corplemented by the system of state standards developed and established by the S1.ate Committee on Standards (Gosstandart of the USSR). The system of standards extends the system of regulatory documents by ensuring nuclear plant safety' through establishing requirements for many components, materials, processes, etc. (Semenov 1983). 
New Soviet regulations require that nuclear power stations be built at least $25 \mathrm{~km}$ from cities over 100,000 in population, but they do not prohibit cities from being built around existing nuclear sites (Nucleonics Week 9/88b). Also, the nature of district heating, where used, requires district heating reactors to be located closer to the population centers, but the new regulations limit the distance between district heating units and population centers to $5 \mathrm{~km}$ (NEI 4/89). Longer and more stringent licensing procedures for nuclear reactors are being encountered to meet the more stringent safety requirements and to backfit improved safety features developed in 1988 into existing projects. An example reason for the delays is the new requirement to carry out more detailed site-specific seismic analyses (MacLachlan 1989).

Vladimir Asmilov, a key Soviet scientist, believes the target for reactor core melt damage probability should be no more than once per 100,000 reactoryears, and that for an accident with off-site consequences should be once per $10^{6}$ to $10^{7}$ reactor years. He feels that the Soviets need to learn more on how to assess the safety of their reactors in this manner and to carry out such assessments in close international cooperation (NEI 4/89).

The Soviets have recently used internal and international peer groups to review the design and safety aspects of their reactor systems. At the end of 1988, an Operational Safety Review Team (OSART) sponsored by the International Atomic Energy Agency (IAEA) visited the Rovno-3 WVER-1000 unit. Other OSART missions are expected in the future, including one to a RBMK unit. Also, the Gorky AST-500 district heating station has been reviewed by a peer group under the auspices of the IAEA. This review included concept and design analysis, as well as some probabilistic safety assessment (NEI 4/89).

\section{A7.11 USSR NUCLEAR REACTORS: TABLES AND FIGURES}

The following tables and figures appear in this section:

TABLE A7.2 USSR Power Reactors - Operational and Shutdown

TABLE A7.3 USSR Power Reactors - Planned

TABLE A7.4 USSR Research and Test Reactors Built or Authorized 
TABLE A7.5 USSR Power Reactors Stopped or Cancelled Since the Chernobyl \#4 Accident

TABLE A7.6 USSR Power Reactor History: Generation Capacity From 1958-1989

TABLE A7.7 USSR Power Reactor History: Units on Line From 1958-1989

TABLE A7.8 Countries With Reactors Operating (or Planned) Using USSRSupplied Fuel

FIGURE A7.1 USSR Yearly Nuclear Power Generation Capacity

FIGURE A7.2 USSR Total Nuclear Power Generation Capacity 


\section{TABLE A7.2. USSR Power Reactors - Operational and Shutdown}

\begin{tabular}{|c|c|c|c|c|c|}
\hline Location & Name & Type & $\begin{array}{l}\text { Capacity, } \\
\text { Mwe } \\
\end{array}$ & $\begin{array}{l}\text { Year in } \\
\text { Operation }\end{array}$ & Reference \\
\hline abninsk & $A M-1$ & $\begin{array}{l}\text { Pressurized water (PWR). } \\
\text { graphite moderated }\end{array}$ & 5 & 1954 & A \\
\hline$"$ & -- & Mobile; PWR & 1.5 & 1961 & A \\
\hline Siberian & Unit 1 & LWGR & 100 & 1958 & 8 \\
\hline " & Unit 2 & LWGR & 100 & 1958 & B \\
\hline$"$ & Unit 3 & LWGR & 100 & 1958 & 8 \\
\hline$"$ & Unit 4 & LWGR & 100 & 1958 & $B$ \\
\hline$"$ & Unit 5 & LHGR & 100 & 1958 & $B$ \\
\hline$"$ & Unit 6 & LWGR & 100 & 1958 & B \\
\hline New Melekess & ARBUS & \multicolumn{2}{|c|}{ Organic-cooled and -moderated $(0.75)^{(a)}$} & $(1963)$ & A \\
\hline " & -- & Boiling water & (50) & $(1964)$ & A \\
\hline$"$ & -- & Boiling water; superheat & $?$ & $?$ & A \\
\hline $\begin{array}{l}\text { Beloyarsk } \\
\text { (Zarechnyy, Sverdlovsk) }\end{array}$ & AMB -1 & $\begin{array}{l}\text { Boiling water; superheat: } \\
\text { graphite moderated }\end{array}$ & $100^{(b)}$ & 1963 & A, B, C \\
\hline & $A M B-2$ & $\begin{array}{l}\text { Boiling water; superheat; } \\
\text { graphite moderated }\end{array}$ & 200 & 1967 & A, $\mathrm{B}$ \\
\hline$"$ & $B N-600$ & LMFBR & 600 & 1981 & D \\
\hline Novovoronezh & Unit 1 & WVER ${ }^{(c)}$ & 210 & 1964 & $A, D$ \\
\hline$"$ & Unit 2 & VWER & 365 & 1969 & 8 \\
\hline “ & Unit 3 & WVER & 440 & 1971 & $B$ \\
\hline$"$ & Unit 4 & VVER & 440 & 1972 & B \\
\hline$"$ & Unit 5 & VYER & 1000 & 1981 & 0 \\
\hline Ulyanorsk & $V K-50$ & BWR & 50 & 1965 & B \\
\hline$"$ & Unit 1 & LMFBR & 12 & 1969 & B \\
\hline Shevchenko & & & & & \\
\hline (Caspian Sea) & $\mathrm{BN}-350$ & LMFBR & $350^{(d)}$ & 1973 & $\mathrm{~B}$ \\
\hline Bilibino & Unit 1 & LWGR & 12 & 1973 & $B$ \\
\hline$"$ & Unit 2 & LWGR & 12 & 1974 & $B$ \\
\hline$"$ & Un it 3 & LWGR & 12 & 1975 & B \\
\hline$"$ & Unit 4 & LWGR & 12 & 1976 & $\mathrm{~B}$ \\
\hline Kola or Kolsk & Unit 1 & WEER & 440 & 1973 & B. D \\
\hline (Polyarnyye & Unit 2 & WER & 440 & 1974 & B \\
\hline Zori, Murmansk) & Unit 3 & WER & 440 & 1982 & 0 \\
\hline 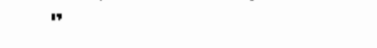 & Unit 4 & WWER & 440 & 1984 & 0 \\
\hline Sosnoviy Bor, Leningrad & Unit 1 & RBMK & 1000 & 1973 & B \\
\hline & Unit 2 & RBMK & 1000 & 1975 & $B$ \\
\hline$"$ & Unit 3 & R日NK & 1000 & 1979 & $B$ \\
\hline$"$ & Unit 4 & RBMK & 1000 & 1981 & 0 \\
\hline $\begin{array}{l}\text { Oktemberyan, Arrnenia } \\
\text { " }\end{array}$ & $\begin{array}{l}\text { Unit } 1 \\
\text { Unit } 2\end{array}$ & $\begin{array}{l}\text { VVER } \\
\text { VWER }\end{array}$ & ${ }_{408}^{(e)}(e)$ & $\begin{array}{l}1976 \\
1979\end{array}$ & $\begin{array}{l}B, E \\
B, E\end{array}$ \\
\hline
\end{tabular}


IABLE A7.2. (contd)

\begin{tabular}{|c|c|c|c|c|c|}
\hline Location & Name & Type & $\begin{array}{l}\text { Capacity, } \\
\text { Mive }\end{array}$ & $\begin{array}{l}\text { Year in } \\
\text { Operation }\end{array}$ & Reference \\
\hline $\begin{array}{l}\text { Kursk } \\
\text { (Kurchatov, Kursk) } \\
"\end{array}$ & $\begin{array}{l}\text { Unit } 1 \\
\text { Unit } 2 \\
\text { Unit } 3 \\
\text { Unit } 4\end{array}$ & $\begin{array}{l}\text { RBMK } \\
\text { RBMK } \\
\text { RBMK } \\
\text { RBMK }\end{array}$ & $\begin{array}{l}1000 \\
1000 \\
1000 \\
1000\end{array}$ & $\begin{array}{l}1975 \\
1979 \\
1984 \\
1986\end{array}$ & $\begin{array}{l}B \\
B \\
D \\
D\end{array}$ \\
\hline $\begin{array}{l}\text { Chernobyl } \\
\text { (Pripyat, Ukraine) } \\
" \\
"\end{array}$ & $\begin{array}{l}\text { Unit } 1 \\
\text { Unit } 2 \\
\text { Unit } 3 \\
\text { Unit } 4\end{array}$ & $\begin{array}{l}\text { RBMK } \\
\text { RBMK } \\
\operatorname{RBMK}(f) \\
\operatorname{RBMK}^{(f)}\end{array}$ & $\begin{array}{l}1000 \\
1000 \\
1000 \\
1000\end{array}$ & $\begin{array}{l}1977 \\
1979 \\
1982 \\
1983\end{array}$ & $\begin{array}{l}B \\
B \\
0 \\
D\end{array}$ \\
\hline $\begin{array}{l}\text { Smolersk } \\
\quad \text { (Desnogorsk. Smolemsk) }\end{array}$ & $\begin{array}{l}\text { Unit } 1 \\
\text { Lnit } 2\end{array}$ & $\begin{array}{l}\text { RBMK } \\
\text { RBMK }\end{array}$ & $\begin{array}{l}1000 \\
1000\end{array}$ & $\begin{array}{l}1979 \\
1985\end{array}$ & $\begin{array}{l}B \\
D\end{array}$ \\
\hline $\begin{array}{l}\text { Rovno } \\
\text { (Kuznetsovsk, } \\
\text { West Ukraine) }\end{array}$ & $\begin{array}{l}\text { Unit } 1 \\
\text { Unit } 2 \\
\text { Unit } 3\end{array}$ & $\begin{array}{l}\text { WUER } \\
\text { WWER } \\
\text { WWER }\end{array}$ & $\begin{array}{r}402 \\
416 \\
1000\end{array}$ & $\begin{array}{l}1981 \\
1982 \\
1987\end{array}$ & $\begin{array}{l}D \\
D \\
D\end{array}$ \\
\hline $\begin{array}{l}\text { Nikolaivev or } \\
\text { Konstantinovka } \\
\text { or South Ukraine } \\
\text { " }\end{array}$ & $\begin{array}{l}\text { Unit } 1 \\
\text { Unit } 2 \\
\text { Unit } 3\end{array}$ & $\begin{array}{l}\text { WWER } \\
\text { WEER } \\
\text { WVER }\end{array}$ & $\begin{array}{l}1000 \\
1000 \\
1000\end{array}$ & $\begin{array}{l}1983 \\
1985 \\
1989\end{array}$ & $\begin{array}{l}\text { B. C } \\
\text { D } \\
\text { D }\end{array}$ \\
\hline $\begin{array}{l}\text { Ignalina } \\
\quad \text { (Srieckus, Lithuania) }\end{array}$ & $\begin{array}{l}\text { Unit 1 } \\
\text { Unit } 2\end{array}$ & $\begin{array}{l}\text { RBMK } \\
\text { REMK }\end{array}$ & $\begin{array}{l}1500 \\
1500\end{array}$ & $\begin{array}{l}1985 \\
1987\end{array}$ & $\begin{array}{l}0 \\
0\end{array}$ \\
\hline $\begin{array}{l}\text { Kalinin } \\
\text { (Udomlya, Kalinis) }\end{array}$ & $\begin{array}{l}\text { Unit } 1 \\
\text { Unit } 2\end{array}$ & $\begin{array}{l}\text { WWER } \\
\text { WVER }\end{array}$ & $\begin{array}{l}1000 \\
1000\end{array}$ & $\begin{array}{l}1985 \\
1987\end{array}$ & $\begin{array}{l}D \\
D\end{array}$ \\
\hline $\begin{array}{l}\text { Zaporozhye } \\
\quad \text { (Energodar. Ukraine) }\end{array}$ & $\begin{array}{l}\text { Unit } 1 \\
\text { Unit } 2 \\
\text { Unit } 3 \\
\text { Unit } 4 \\
\text { Unit } 5\end{array}$ & $\begin{array}{l}\text { WVER } \\
\text { YWER } \\
\text { WVER } \\
\text { YVER } \\
\text { WVER }\end{array}$ & $\begin{array}{l}1000 \\
1000 \\
1000 \\
1000 \\
1000\end{array}$ & $\begin{array}{l}1985 \\
1985 \\
1987 \\
1987 \\
1989\end{array}$ & $\begin{array}{l}D \\
D \\
0 \\
D \\
F\end{array}$ \\
\hline $\begin{array}{l}\text { 8alakovo } \\
\text { (8alakovo, Saratow) }\end{array}$ & $\begin{array}{l}\text { Unit } 1 \\
\text { Unit } 2\end{array}$ & $\begin{array}{l}\text { WVER } \\
\text { WVER }\end{array}$ & $\begin{array}{l}1000 \\
1000\end{array}$ & $\begin{array}{l}1986 \\
1987\end{array}$ & $\begin{array}{l}0 \\
0\end{array}$ \\
\hline $\begin{array}{l}\text { Khmel'nitskiy } \\
\text { (Netes רin. } \\
\text { West. kraine) }\end{array}$ & Unit 1 & WHER & 1000 & 1987 & 0 \\
\hline
\end{tabular}

Referenices:

$A=$ Seathorg, et a]., May 1963.

Notes:

$B=$ Atorinaya Energiya, November 1977.

$C=$ Nuclear News, August 1987.

$D=$ Nuclear News. February 1989.

(a) Data in parentheses represent estimates.

(b) Plant was taken off line for decomissioning in 1987. Reference $C$.

$E=$ Hucleonics Week, March 9, 1989, pg. 3.

(c) Plant was taken off 7 ine for decomissioning in 1988 , Reference D. (It was noted that the plant was shut down in 1984, according to information given during a National Academy of Sciences tour February 10-25, 1990 to the USSR.)

(d) Plant also desalinates 120,000 cubic neters of seawater per day.

(e) WVER-440 has an output of $405 \mathrm{MWe}$ due to cooling conditions (Reference 8 ). Units 1 and 2 were shut down in February and March of 1989 respectively for conversion to a fossil-fired plant (Reference E).

(f) Unit 4 was destroyed in an accident on April 26. 1986. 
TABLE A7.3. USSR Power Reactors - Planned (a)

\begin{tabular}{|c|c|c|c|c|}
\hline _____ocation & Name & Type & $\begin{array}{l}\text { Capacity, } \\
\text { MWe }\end{array}$ & $\begin{array}{l}\text { Expected } \\
\text { Year for } \\
\text { operation }\end{array}$ \\
\hline $\begin{array}{l}\text { Konstantinovka } \\
\text { (South Ukraine) }\end{array}$ & Unit 4 & VVER & 950 & 1989 \\
\hline $\begin{array}{l}\text { Tatar } \\
\text { (Kama, Tatar) }\end{array}$ & Unit 1 & WVER & 950 & 1989 \\
\hline $\begin{array}{l}\text { Khmel'nitskiy } \\
\text { (Neteshin, Ukraine) }\end{array}$ & $\begin{array}{l}\text { Unit } 2 \\
\text { Unit } 3\end{array}$ & $\begin{array}{l}\text { VWER } \\
\text { VVER }\end{array}$ & $\begin{array}{l}950 \\
950\end{array}$ & $\begin{array}{l}1989 \\
1990\end{array}$ \\
\hline $\begin{array}{l}\text { Bashkir } \\
\text { (Agide1, Baskir) }\end{array}$ & $\begin{array}{l}\text { Unit } 1 \\
\text { Unit } 2\end{array}$ & $\begin{array}{l}\text { WVER } \\
\text { WVER }\end{array}$ & $\begin{array}{l}950 \\
950\end{array}$ & $\begin{array}{l}1989 \\
1990\end{array}$ \\
\hline $\begin{array}{l}\text { Crimea } \\
\text { (Shchelkino, Ukraine) }\end{array}$ & $\begin{array}{l}\text { Unit } 1 \\
\text { Unit } 2\end{array}$ & $\begin{array}{l}\text { WVER } \\
\text { WVER }\end{array}$ & $\begin{array}{l}950 \\
950\end{array}$ & $\begin{array}{l}1989 \\
1990\end{array}$ \\
\hline $\begin{array}{l}\text { Rostov } \\
\text { (Volgodansk, Rostov) }\end{array}$ & $\begin{array}{ll}\text { Unit } & 1 \\
\text { Unit } & 2 \\
\text { Unit } & \\
\text { Unit } & 4\end{array}$ & $\begin{array}{l}\text { WVER } \\
\text { WVER } \\
\text { VVER } \\
\text { WVER }\end{array}$ & $\begin{array}{l}950 \\
950 \\
950 \\
950\end{array}$ & $\begin{array}{l}1989 \\
1990 \\
1991 \\
1992\end{array}$ \\
\hline $\begin{array}{l}\text { Baiakovo } \\
\text { (Balakovo, Saratov) }\end{array}$ & Unit 3 & VVER & 950 & 1990 \\
\hline $\begin{array}{l}\text { Rovno } \\
\text { (Kuznetsovsk, Ukraine) }\end{array}$ & Unit 4 & VVER & 950 & 1990 \\
\hline $\begin{array}{l}\text { Smolensk } \\
\text { (Desnogorsk, Smolensk) }\end{array}$ & $\begin{array}{ll}\text { Unit } & 3 \\
\text { Unit } 4\end{array}$ & $\begin{array}{l}\text { RBMK } \\
\text { RBMK }\end{array}$ & $\begin{array}{l}950 \\
950\end{array}$ & $\begin{array}{l}1990 \\
1991\end{array}$ \\
\hline $\begin{array}{l}\text { Beloyarskiy } \\
\text { (Zarechnyy, Sverdlovsk) }\end{array}$ & $\mathrm{BN}-800$ & LMFBR & 800 & 1993 \\
\hline $\begin{array}{l}\text { Kostroma } \\
\text { (Buy, Kostroma) }\end{array}$ & $\begin{array}{l}\text { Unit } 1 \\
\text { Unit } 2\end{array}$ & $\begin{array}{l}\text { RBMK } \\
\text { RBMK }\end{array}$ & $\begin{array}{l}1450 \\
1450\end{array}$ & $\begin{array}{l}1993 \\
1994\end{array}$ \\
\hline $\begin{array}{l}\text { Kursk } \\
\text { (Kurchatov, Kursk) }\end{array}$ & Unit 5 & VVER & 950 & 1994 \\
\hline
\end{tabular}

(a) Nuclear News, February 1989. 
IABLE A7.4. USSR Research and Test Reactors Built or Authorized (a)

\begin{tabular}{|c|c|c|c|c|c|}
\hline Name & Location & Purpose & Type & $\begin{array}{l}\text { Capacity. } \\
M W(t h)\end{array}$ & $\begin{array}{l}\text { Year in } \\
\text { Operation }\end{array}$ \\
\hline- & Moscow, Kurchatov & Reactor physics & Natura] U-graphite & 5.5 & 1946 \\
\hline $\operatorname{IRT}(b)$ & Hoscow, Kurchatov & Research & Swimning pool & 2 & 1952 \\
\hline RPT & Hoscow. Kurchatov & Materials testing & $\mathrm{H}_{2} \mathrm{O}$-tank & 20 & 1952 \\
\hline$B R-:$ & Obninsk & Fast reactor physics & Pu meta 1-uncooled & Q & 1955 \\
\hline$B R-\ddot{z}$ & Obninsk & Fast reactor experience & $\mathrm{PuO}_{2}$-mercury cooled & 0.1 & dismant led \\
\hline$B R=-$ & obrinsk & Reactor phys ics & Fast-themal & 8 & dismant led \\
\hline$B R-t$ & Obrinsk & Fast reactor experience & $\mathrm{PuO}_{2}$-sodium-cooled & 5 & 1959 \\
\hline BFS & obninsk & $\begin{array}{l}\text { Critical measurement of } \\
\text { large fast systems }\end{array}$ & Fast critical assembly & $B$ & $?$ \\
\hline$S M-2$ & New Me lekess & $\begin{array}{l}\text { Transuranium production } \\
\text { and materials testing }\end{array}$ & $\mathrm{H}_{2} \mathrm{O}$-tank & 50 & 1962 \\
\hline-- & New Melekess & Materials testing & $\mathrm{H}_{2} \mathrm{O}-\tan \mathrm{x}$ & (75) & $(1965)$ \\
\hline WVRM & Leningrad, Ioffe & Research & $D_{2} 0-\tan k$ & 16 & 1960 \\
\hline Merry-go-round & Dubna & Pulsed fast neutrons & Godiva & Variable & $?$ \\
\hline
\end{tabular}

(a) Seaborg et a 1., May 1963.

(b) About 10 other similar reactors eisewhere in the USSR.

NOIE: Data in parentheses represent estimates. 
TABLE A7.5. USSR Power Reactors Stopped or Cancelled Since the Chernobyl \#4 Accident (MacLachian 1989)

\begin{tabular}{|c|c|c|c|c|}
\hline $\begin{array}{l}\text { Station } \\
\text { (Location) }\end{array}$ & $\begin{array}{l}\text { No. } \\
\text { Unit }\end{array}$ & Type & Status Early 1988 & Reason \\
\hline \multirow{2}{*}{$\begin{array}{l}\text { Chernobyl } \\
\text { (Ukraine) }\end{array}$} & 4 & RBMK- 1000 & Completed & Accident \\
\hline & $\begin{array}{l}5 \\
6\end{array}$ & $\begin{array}{l}\text { RBMK - } 1000 \\
\text { RBMK-1000 }\end{array}$ & $\begin{array}{l}\text { Under construction } \\
\text { Under construction }\end{array}$ & $\begin{array}{l}\text { Accident } \\
\text { Accident }\end{array}$ \\
\hline $\begin{array}{l}\text { Novovoronezh } \\
\text { (Russia) }\end{array}$ & 1 & WVER-200 & Completed & 01d prototype \\
\hline \multirow[t]{4}{*}{$\begin{array}{l}\text { Oktemberyan } \\
\text { (Armenia) }\end{array}$} & 1 & WVER-440 & Completed & $\begin{array}{l}\text { Backfits too expensive; } \\
\text { seismic risk }\end{array}$ \\
\hline & 2 & VVER-440 & Completed & \\
\hline & 3 & WVER-1000 & Planned & Seismic risk \\
\hline & 4 & WVR- 1000 & Planned & Seismic risk \\
\hline $\begin{array}{l}\text { Georgia } \\
\text { (Georgia) }\end{array}$ & 1 & VWER-1000 & Under construction & $\begin{array}{l}\text { Seismic risk; public } \\
\text { opposition }\end{array}$ \\
\hline \multirow[t]{2}{*}{$\begin{array}{l}\text { Ignalina } \\
\text { (Lithuania) }\end{array}$} & 3 & RBMK- 1500 & Under construction & $\begin{array}{l}\text { Delayed for design update; } \\
\text { public opposition }\end{array}$ \\
\hline & 4 & RBMK- 1500 & Under construction & $\begin{array}{l}\text { Insufficient cooling water; } \\
\text { public opposition }\end{array}$ \\
\hline \multirow{2}{*}{$\begin{array}{l}\text { Kharkov } \\
\text { (Ukraine) }\end{array}$} & 1 & VVER-1000 & Under construction & \multirow{2}{*}{$\begin{array}{l}\text { No more nuclear cogenera- } \\
\text { tion units close to cities } \\
\text { " }\end{array}$} \\
\hline & 2 & WVER-1000 & PTanned & \\
\hline $\begin{array}{l}\text { Krasnodar } \\
\text { (Caucasus) }\end{array}$ & 1 & WVER-1000 & Under construction & Seismic risk \\
\hline $\begin{array}{l}\text { Minsk } \\
\text { (Byelorussia) }\end{array}$ & $\frac{1}{2}$ & $\begin{array}{l}\text { VVER-1000 } \\
\text { VVER-1000 }\end{array}$ & $\begin{array}{l}\text { Under construction } \\
\text { Planned }\end{array}$ & $\begin{array}{l}\text { Co-generation unit } \\
\text { Co-generation unit }\end{array}$ \\
\hline $\begin{array}{l}\text { Odessa } \\
\text { (S. Ukraine) }\end{array}$ & $\begin{array}{l}1 \\
2\end{array}$ & $\begin{array}{l}\text { VVER-1000 } \\
\text { VVER-1000 }\end{array}$ & $\begin{array}{l}\text { Under construction } \\
\text { Under construction }\end{array}$ & $\begin{array}{l}\text { Co-generation unit } \\
\text { Co-generation unit }\end{array}$ \\
\hline \multirow[t]{2}{*}{$\begin{array}{l}\text { Sangachaly } \\
\text { (Azerbaijan) }\end{array}$} & $i$ & WVER-1000 & Under construction & \multirow[t]{2}{*}{$\begin{array}{l}\text { Seismic risk; public } \\
\text { opposition }\end{array}$} \\
\hline & 2 & VVER-1000 & Planned & \\
\hline $\begin{array}{l}\text { Aktash } \\
\text { (Kertch) }\end{array}$ & $\begin{array}{l}3 \\
4\end{array}$ & $\begin{array}{l}\text { WVER-1000 } \\
\text { VVER-1000 }\end{array}$ & $\begin{array}{l}\text { Planned } \\
\text { Planned }\end{array}$ & " " " \\
\hline $\begin{array}{l}\text { Volgograd } \\
\text { (Russia) }\end{array}$ & $\begin{array}{l}1 \\
2\end{array}$ & $\begin{array}{l}\text { WVER-1000 } \\
\text { VVER-1000 }\end{array}$ & $\begin{array}{l}\text { Under construction } \\
\text { Planned }\end{array}$ & $\begin{array}{l}\text { Co-generation unit } \\
\text { Co-generation unit }\end{array}$ \\
\hline
\end{tabular}


TABLE A7.6. USSR Power Reactor History: Generation Capacity from 1958-1989

\begin{tabular}{|c|c|c|c|c|c|}
\hline \multirow[b]{2}{*}{ Year } & \multicolumn{4}{|c|}{ Reactor Type } & \multirow[b]{2}{*}{ Totals, MWe } \\
\hline & BWR, MWe & RBMK, MWe (a) & WVER, MWe & FBR, MWe & \\
\hline $\begin{array}{l}1958 \\
1959\end{array}$ & & $\begin{array}{l}600 \\
600\end{array}$ & $\begin{array}{l}0 \\
0\end{array}$ & $\begin{array}{l}0 \\
0\end{array}$ & $\begin{array}{l}600 \\
600\end{array}$ \\
\hline $\begin{array}{l}1960 \\
1961 \\
1962 \\
1963 \\
1964 \\
1965 \\
1966 \\
1967 \\
1968 \\
1969\end{array}$ & $\begin{array}{l}100 \\
100 \\
150 \\
150 \\
350 \\
350 \\
350\end{array}$ & $\begin{array}{l}600 \\
600 \\
600 \\
600 \\
600 \\
600 \\
600 \\
600 \\
600 \\
600\end{array}$ & $\begin{array}{r}0 \\
0 \\
0 \\
0 \\
210 \\
210 \\
210 \\
210 \\
210 \\
575\end{array}$ & $\begin{array}{l}0 \\
0 \\
0 \\
0 \\
0 \\
0 \\
0 \\
0 \\
0 \\
0\end{array}$ & $\begin{array}{r}600 \\
600 \\
600 \\
700 \\
910 \\
960 \\
960 \\
1160 \\
1160 \\
1525\end{array}$ \\
\hline $\begin{array}{l}1970 \\
1971 \\
1972 \\
1973 \\
1974 \\
1975 \\
1976 \\
1977 \\
1978 \\
1979\end{array}$ & $\begin{array}{l}350 \\
350 \\
350 \\
350 \\
350 \\
350 \\
350 \\
350 \\
350 \\
350\end{array}$ & $\begin{array}{r}600 \\
600 \\
600 \\
1600 \\
1600 \\
2600 \\
3600 \\
4600 \\
4600 \\
8600\end{array}$ & $\begin{array}{r}575 \\
1015 \\
1455 \\
1895 \\
2335 \\
2335 \\
2743 \\
2743 \\
2743 \\
3151\end{array}$ & $\begin{array}{r}0 \\
0 \\
0 \\
350 \\
350 \\
350 \\
350 \\
350 \\
350 \\
350\end{array}$ & $\begin{array}{r}1525 \\
1965 \\
2405 \\
4195 \\
4635 \\
5635 \\
7043 \\
8043 \\
8043 \\
12451\end{array}$ \\
\hline $\begin{array}{l}1980 \\
1981 \\
1982 \\
1983 \\
1984 \\
1985 \\
1986 \\
1987 \\
1988 \\
1989\end{array}$ & $\begin{array}{l}350 \\
350 \\
350 \\
350 \\
350 \\
350 \\
350 \\
250 \\
250 \\
250\end{array}$ & $\begin{array}{r}8600 \\
9600 \\
10600 \\
11600 \\
12600 \\
14100 \\
15100 \\
16600 \\
16600 \\
16600\end{array}$ & $\begin{array}{r}3151 \\
4553 \\
5409 \\
6409 \\
6849 \\
10849 \\
11849 \\
17849 \\
18849 \\
20033\end{array}$ & $\begin{array}{l}350 \\
950 \\
950 \\
950 \\
950 \\
950 \\
900 \\
950 \\
950 \\
950\end{array}$ & $\begin{array}{l}12451 \\
15453 \\
17309 \\
19309 \\
20749 \\
26249 \\
28199 \\
35649 \\
36649 \\
37833\end{array}$ \\
\hline
\end{tabular}

(a) Includes Siberian LWGRs.

Reference: Based on Table A7.1. 
TABLE A7.7. USSR Power Reactor History: Units on Line from 1958-1989

Reactor Type

\begin{tabular}{|c|c|c|c|c|c|}
\hline Year & BWR, MWe & RBMK, MWe (a) & WVER, MWe & FBR, MWe & Totals, MWe \\
\hline $\begin{array}{l}1958 \\
1959\end{array}$ & $\begin{array}{l}0 \\
0\end{array}$ & $\begin{array}{l}6 \\
6\end{array}$ & $\begin{array}{l}0 \\
0\end{array}$ & $\begin{array}{l}0 \\
0\end{array}$ & $\begin{array}{l}6 \\
6\end{array}$ \\
\hline $\begin{array}{l}1960 \\
1961 \\
1962 \\
1963 \\
1964 \\
1965 \\
1966 \\
1967 \\
1968 \\
1969\end{array}$ & $\begin{array}{l}0 \\
0 \\
0 \\
1 \\
1 \\
2 \\
2 \\
3 \\
3 \\
3\end{array}$ & $\begin{array}{l}6 \\
6 \\
6 \\
6 \\
6 \\
6 \\
6 \\
6 \\
6 \\
6\end{array}$ & $\begin{array}{l}0 \\
0 \\
0 \\
0 \\
1 \\
1 \\
1 \\
1 \\
1 \\
2\end{array}$ & $\begin{array}{l}0 \\
0 \\
0 \\
0 \\
0 \\
0 \\
0 \\
0 \\
0 \\
0\end{array}$ & $\begin{array}{r}6 \\
6 \\
6 \\
7 \\
8 \\
9 \\
9 \\
10 \\
10 \\
11\end{array}$ \\
\hline $\begin{array}{l}1970 \\
1971 \\
1972 \\
1973 \\
1974 \\
1975 \\
1976 \\
1977 \\
1978 \\
1979\end{array}$ & $\begin{array}{l}3 \\
3 \\
3 \\
3 \\
3 \\
3 \\
3 \\
3 \\
3 \\
3\end{array}$ & $\begin{array}{r}6 \\
6 \\
6 \\
7 \\
7 \\
8 \\
9 \\
1 \\
10 \\
14\end{array}$ & $\begin{array}{l}2 \\
3 \\
4 \\
5 \\
6 \\
6 \\
7 \\
7 \\
7 \\
8\end{array}$ & $\begin{array}{l}0 \\
0 \\
0 \\
1 \\
1 \\
1 \\
1 \\
1 \\
1 \\
1\end{array}$ & $\begin{array}{l}11 \\
12 \\
13 \\
16 \\
17 \\
18 \\
20 \\
21 \\
21 \\
26\end{array}$ \\
\hline $\begin{array}{l}1980 \\
1981 \\
1982 \\
1983 \\
1984 \\
1985 \\
1986 \\
1987 \\
1988 \\
1989\end{array}$ & $\begin{array}{l}3 \\
3 \\
3 \\
3 \\
3 \\
3 \\
3 \\
2 \\
2 \\
2\end{array}$ & $\begin{array}{l}14 \\
15 \\
16 \\
17 \\
18 \\
19 \\
20 \\
21 \\
21 \\
21\end{array}$ & $\begin{array}{r}8 \\
10 \\
12 \\
13 \\
14 \\
18 \\
19 \\
25 \\
25 \\
25\end{array}$ & $\begin{array}{l}1 \\
2 \\
2 \\
2 \\
2 \\
2 \\
2 \\
2 \\
2 \\
2\end{array}$ & $\begin{array}{l}26 \\
30 \\
33 \\
35 \\
37 \\
42 \\
44 \\
50 \\
50 \\
50\end{array}$ \\
\hline
\end{tabular}

(a) Includes Siberian LWGRs.

Reference: Based on Table A7.1. 
IABLE A7.8. Countries with Reactors Operating (or Planned) Using USSR-Supplied Fuel (Nuclear News 8/89)

\begin{tabular}{|c|c|c|c|c|}
\hline Location & Name & & $\begin{array}{c}\text { Capacity. } \\
\text { Mile } \\
\end{array}$ & $\begin{array}{c}\text { Year in } \\
\text { Operation }\end{array}$ \\
\hline Bulgaria & Koz loduy & -1 & 440 & 1974 \\
\hline "1 & " & -2 & " & 1975 \\
\hline$"$ & " & -3 & $"$ & 1981 \\
\hline " & $"$ & -4 & " & 1982 \\
\hline$\ddot{*}$ & $"$ & -5 & 1000 & 1988 \\
\hline " & " & -6 & " & 1989 \\
\hline$"$ & Be lene & -1 & $n$ & 1992 \\
\hline$"$ & 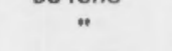 & -2 & $"$ & 1994 \\
\hline Cuba & Juragua & -1 & $"$ & 1990 \\
\hline " & " & -2 & $\bullet$ & 1992 \\
\hline Czechos lovak ia & Bohunice & -1 & 446 & 1979 \\
\hline " & $"$ & -2 & " & 1981 \\
\hline$"$ & $"$ & -3 & $n$ & 1985 \\
\hline$"$ & " & -4 & $"$ & 1986 \\
\hline$"$ & Dukovany & -1 & $"$ & 1985 \\
\hline$"$ & " & -2 & $"$ & 1986 \\
\hline$"$ & $"$ & -3 & $"$ & 1987 \\
\hline " & " & -4 & $"$ & 1987 \\
\hline$"$ & Mochovce & -1 & $"$ & 1989 \\
\hline$"$ & " & -2 & $"$ & 1990 \\
\hline$"$ & $"$ & -3 & $"$ & 1991 \\
\hline$"$ & " & -4 & " & 1992 \\
\hline$"$ & Teme l in & -1 & 1000 & 1992 \\
\hline$"$ & " & -2 & " & 1994 \\
\hline " & $"$ & -3 & $"$ & 1995 \\
\hline " & " & -4 & $"$ & 1997 \\
\hline Fin land & Loviisa & -1 & $"$ & 1977 \\
\hline$"$ & " & -2 & " & 1981 \\
\hline Germany (Dem. Rep.) & Rhe insbers & $g-1$ & 70 & 1966 \\
\hline " & Nord & -1 & 440 & 1974 \\
\hline$"$ & " & -2 & $"$ & 1975 \\
\hline 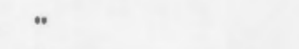 & $"$ & -3 & $n$ & 1978 \\
\hline$"$ & $"$ & -4 & $"$ & 1979 \\
\hline$"$ & $"$ & -5 & $"$ & 1989 \\
\hline$"$ & 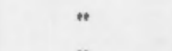 & -6 & $"$ & 1996 \\
\hline$"$ & $"$ & -7 & 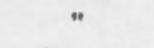 & -- \\
\hline$"$ & " & -8 & " & -- \\
\hline$"$ & Stenda 1 & -1 & 1000 & -- \\
\hline " & " & -2 & " & - \\
\hline Hungary & Paks & -1 & 440 & 1983 \\
\hline " & " & -2 & $"$ & 1984 \\
\hline$"$ & $"$ & -3 & $"$ & 1986 \\
\hline$"$ & $"$ & -4 & " & 1987 \\
\hline " & $"$ & -5 & 1000 & -- \\
\hline " & " & -6 & " & -- \\
\hline Poland & Zarnowiec & -1 & $"$ & 1992 \\
\hline " & $"$ & -2 & $"$ & 1992 \\
\hline " & " & -3 & $"$ & 1994 \\
\hline " & $"$ & -4 & $"$ & 1995 \\
\hline
\end{tabular}




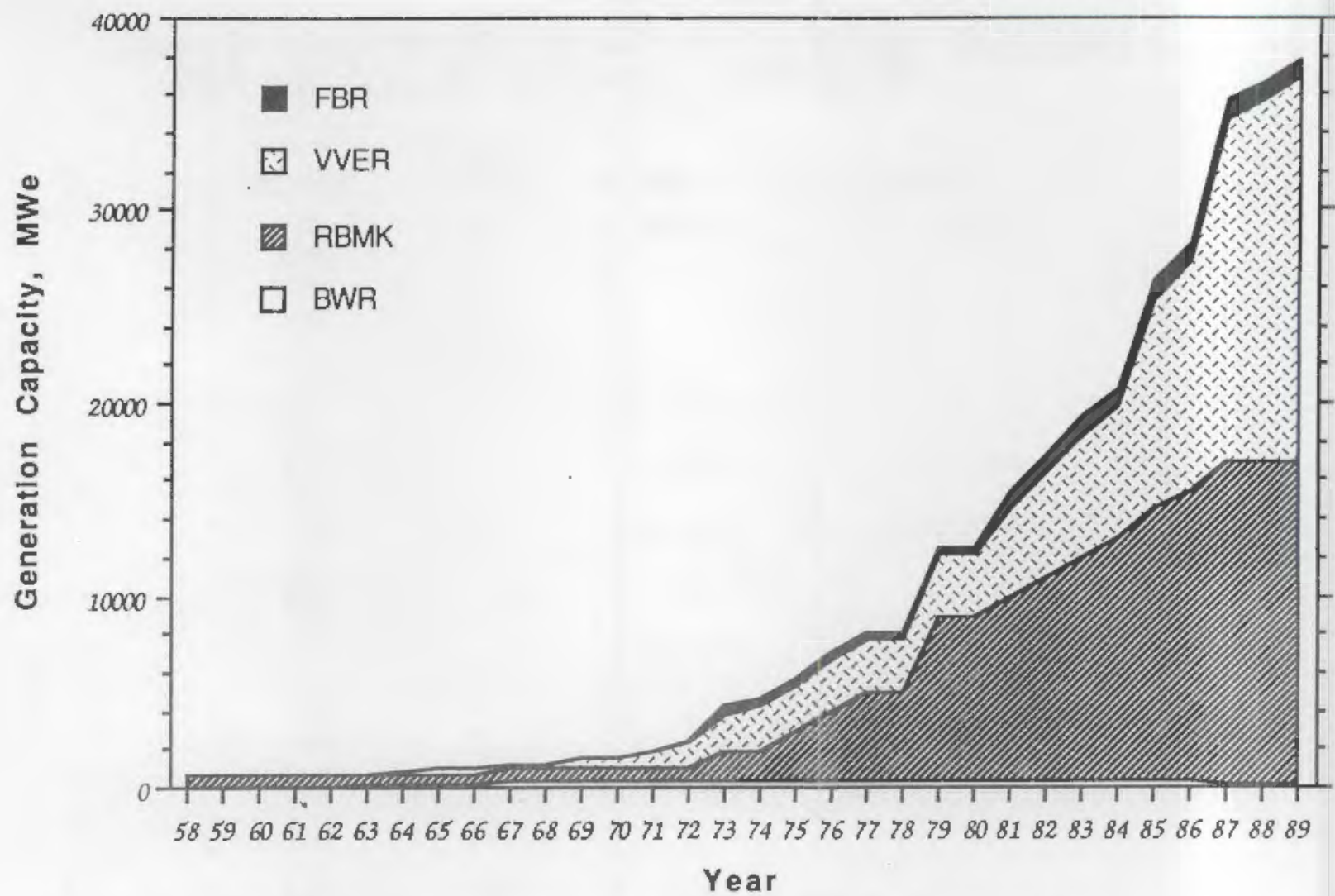

FIGURE A7.1. USSR Yearly Nuclear Power Generation Capacity
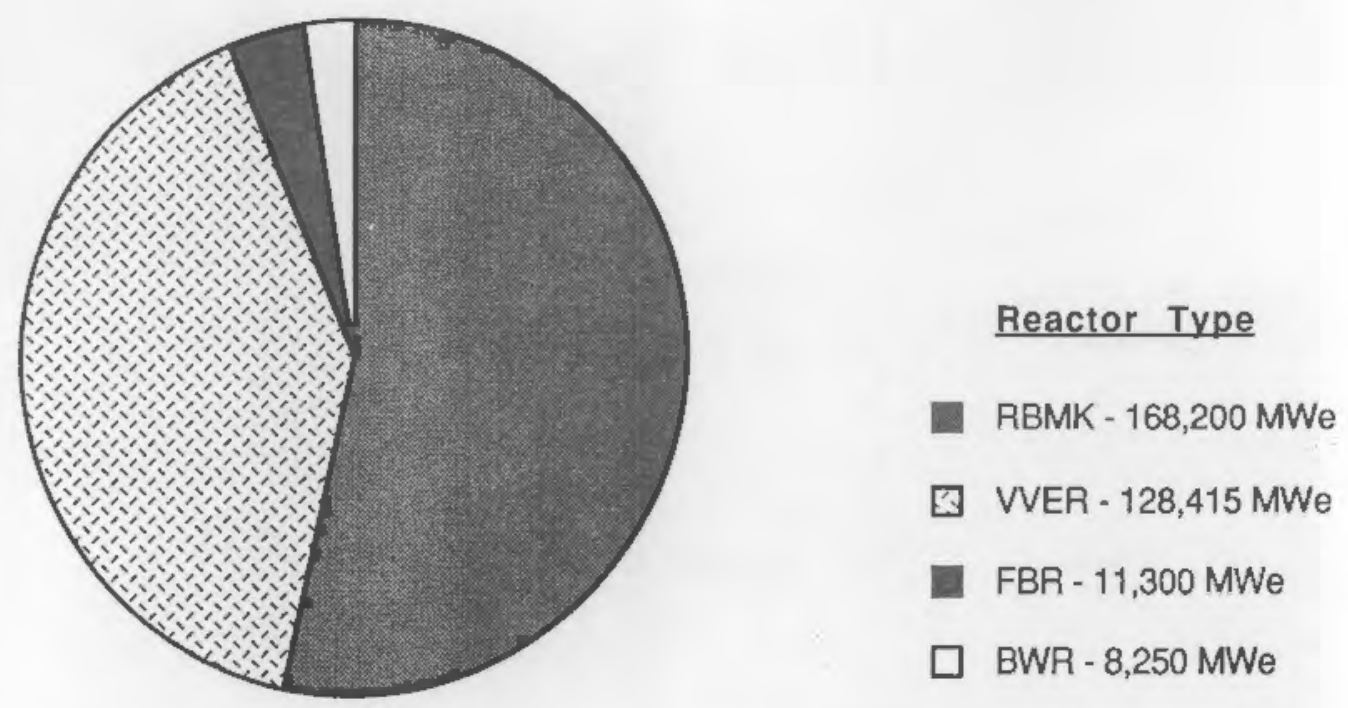

FIGURE A7.2. USSR Cumulative Nuclear Power Generation Capacity: 1958-1989 


\section{APPENDIX B}

MAPS 


\section{APPENDIX B}

\section{MAPS}

\section{LEGEND FOR MAP B.1 USSR Uranium-Thorium Deposits and Processing Centers}

Deposit No, and Location

European USSR

1-Sillamae

2-Zhel tyye Vody-Terny

3-Lermontov

4-Chupa District

5-Lake Onega

6-Lovozero Tundra

$\underline{\text { Urals }}$

7-Vishnevogorsk

8-Novogornyy

Kazakhstan and Central Asia

9-Aksuyek-Ki yakhty

10-Koktas

11-Stepnogorsk
Description

Uranium-phosphate rare earths associated with clays with detrital fishbones.

Uranium mining and milling operations.

Precambrian uranium-iron ore formation.

Irregular stratiform albitized uranium bodies.

Uranium associated with conglomerates. Uranium minerals include uraninite, pitchblende and nenadkevite.

Uranium mining and milling.

Uranium-molybdenum associated with volcanic rocks.

Mining and milling operations.

Uraniferous pegmatites in Precambrian gneisses.

Uranium mineralization in paleovolcanic and intrusive rocks of Baltic shields.

Uranium and vanadium minerals associated with black graphitic marine shales, peat, and asphaltite.

Thorium in phosphate and rare earths in syenite complex.

Uranium with thorium minerals in alkalic rocks.

Uranium mineralization in nepheline syenite intrusions.

Uranium mineralization in nepheline syenite.

Uranium mining.

Uranium associated with copper mining.

Possible in situ leaching of deep-seated uranium deposit.

Uranium extraction as part of the "Tselinnyy Mining Complex."

B. 1 
Deposit No. and Location

12-Ak-Tyuz-Bordunskiy

13-Chigirik

14-Gran itogorsk

15-Min-Kush

16-Tyuya-Muyun

17-Kyzy 1-Dzhar

18-Kadzhi-Say

19-Taboshar

20-Chka lovsk

21-Sumsar

22-Uchkuduk

23-Naugarzan

24-Charkesar

25-Chav lisay-Krasnogorsk iy-Yangiabad

26-Kara-Balta

Siberia

27-Vikhorevka

28-Krasnokamensk

29-S lyudyanka

30-A ldan
Description

Uranium, thorium, and rare earths associated with lead mining.

Uranium milling and processing facilities.

Uranium possibly associated with lead mining, milling, and concentration center.

Uranium mining and milling operations associated with lignite in 1960s.

Uranium-vanadium associated with metamorphic limestone interlayered with volcanic tuffs and breccia.

Tyuyamuyunite, a uranium-vanadium mineral species that was named after this locality.

Uranium mining associated with gold production.

Uranium associated with lignite mining.

Uranium vanadium mining.

$\mathrm{U}_{3} \mathrm{O}_{8}$ extraction plant.

Possible uranium extraction and hexafluoride conversion site for Taboshar mine ore.

Possible uranium mining.

Uranium associated with gold mining at Kokpatas gold mine.

Possible uranium extraction at Navoi Mining and Metallurgical

Complex.

Ore genetically similar to South African deposits.

Uranium-fluorite mining. Ore milling at Chigirik.

Site of former uranium mining.

Site of uranium mining operation.

Uranium processing center.

Possible uranium-thorium mining of vein-type deposits in ultrametamorphic Archean rocks.

Uranium-fluorspar associated with Mesozoic volcanic basins.

Pegmatites-uranium and rare earths.

Mining reported in 1958 from Precambrian crystalline limestone. Uranium, thorium, and rare earths associated with gold mining.

\section{B.2}




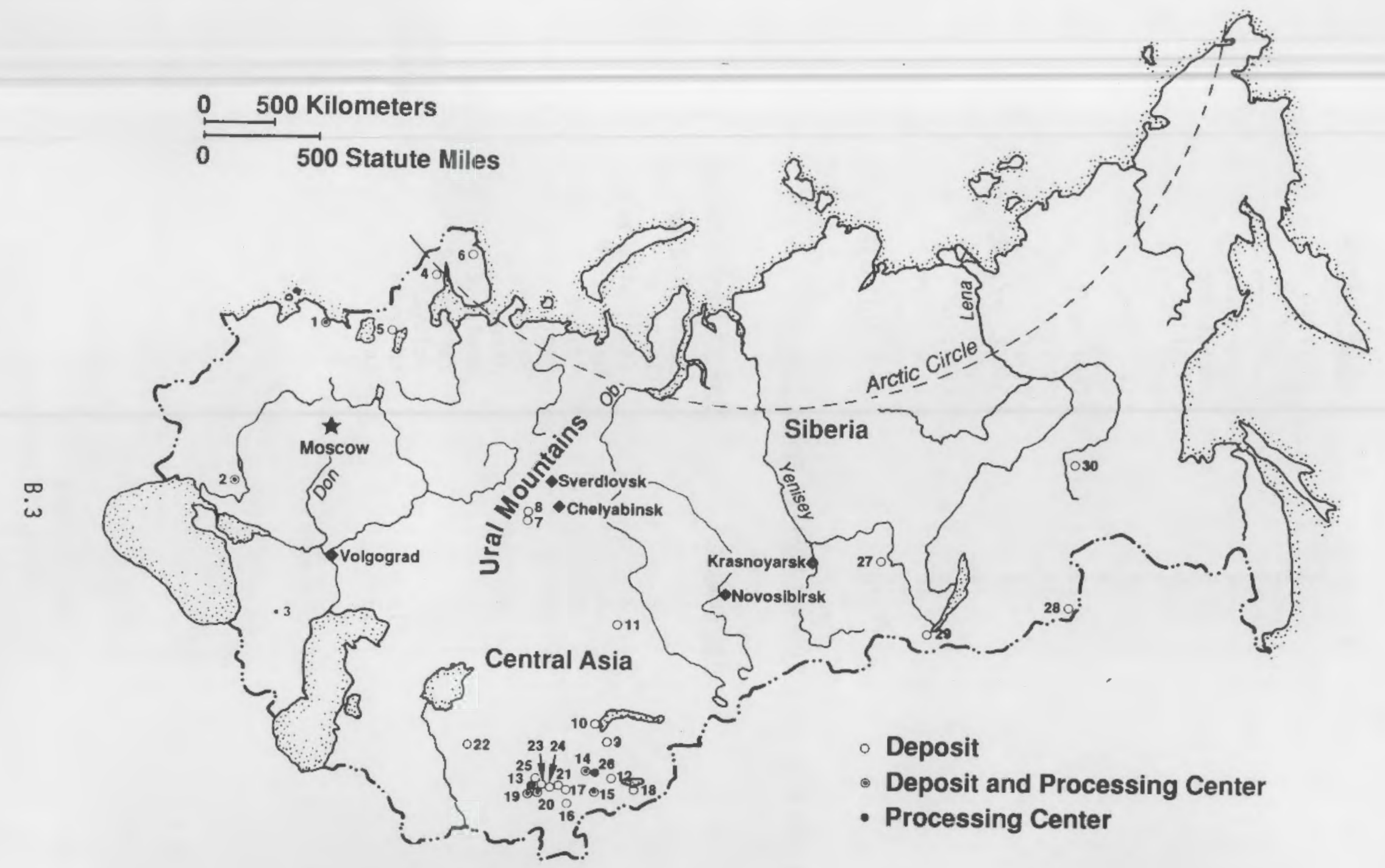

FIGURE B.1. USSR Uranium-Thorium Deposits and Processing Centers 
LEGEND FOR MAP B.2 USSR Nuclear Power Stations

\begin{tabular}{cll} 
Map Number & & Power Station \\
\cline { 3 - 3 } 1 & & Siberian \\
2 & Beloyarsk \\
3 & Novoronezh \\
4 & Ulyunosvsk \\
5 & Shevchenko \\
6 & Bilibino \\
7 & Kola \\
8 & Leningrad \\
9 & Kursk \\
10 & Chernobyl \\
11 & Smolensk \\
12 & Rovno \\
13 & South Ukraine \\
14 & Ignalina \\
15 & Kalinin \\
16 & Zaporozhye \\
17 & Balakovo \\
18 & Khmel'nitskiy
\end{tabular}

LEGEND FOR MAP B.3 USSR Planned Nuclear Power Stations

Map Number

1

2

3

4

5

6

7

8

9

10

11

12

13
Planned Power Station

South Ukraine

Tatar

Khmel'nitskiy

Bashkir

Crimea

Rostov

Bal akovo

Rovno

Smolensk

Zaporozhye

Beloyarsk

Kostroma

Kursk 


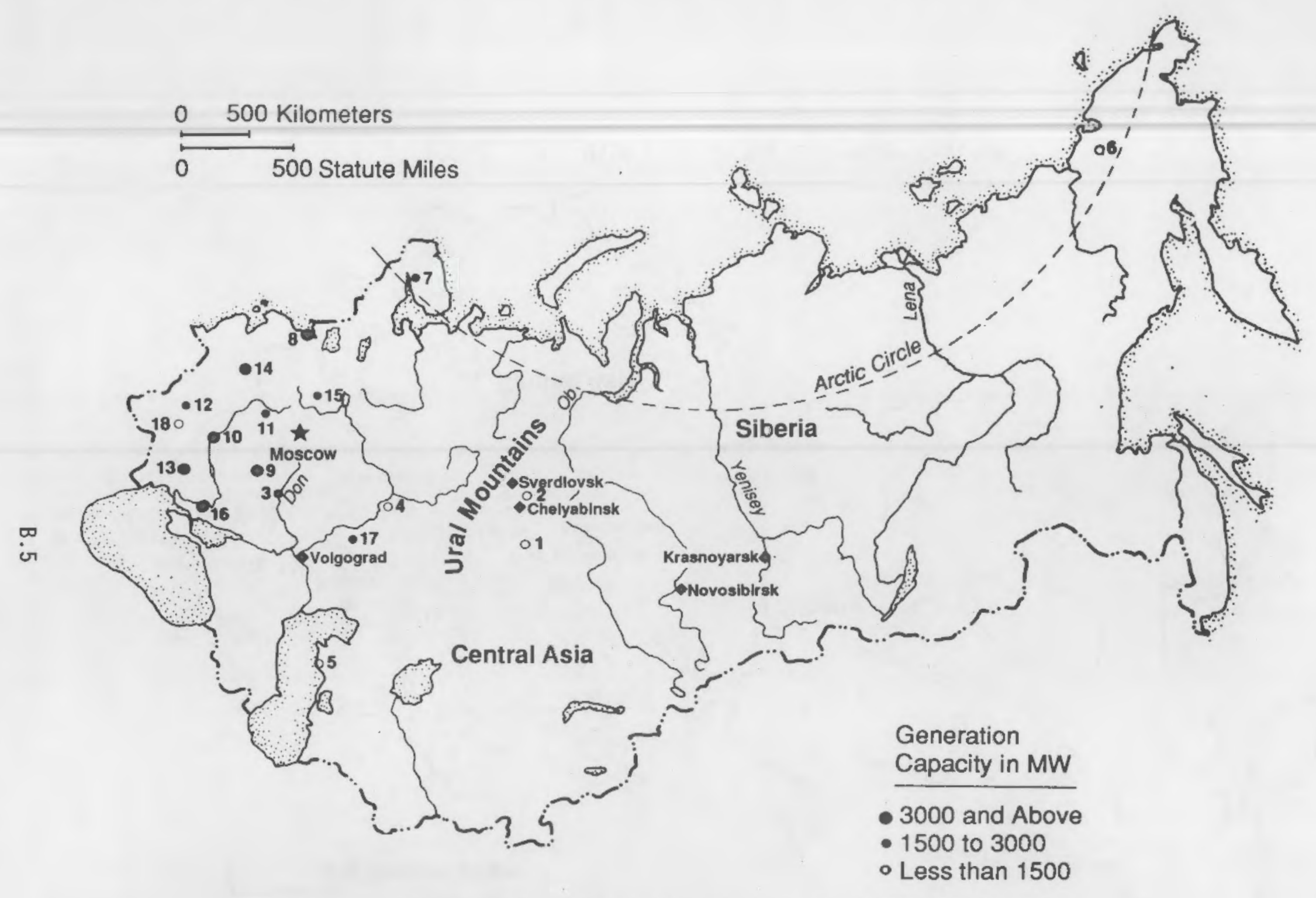

FIGURE B.2. USSR Active Nuclear Power Stations 


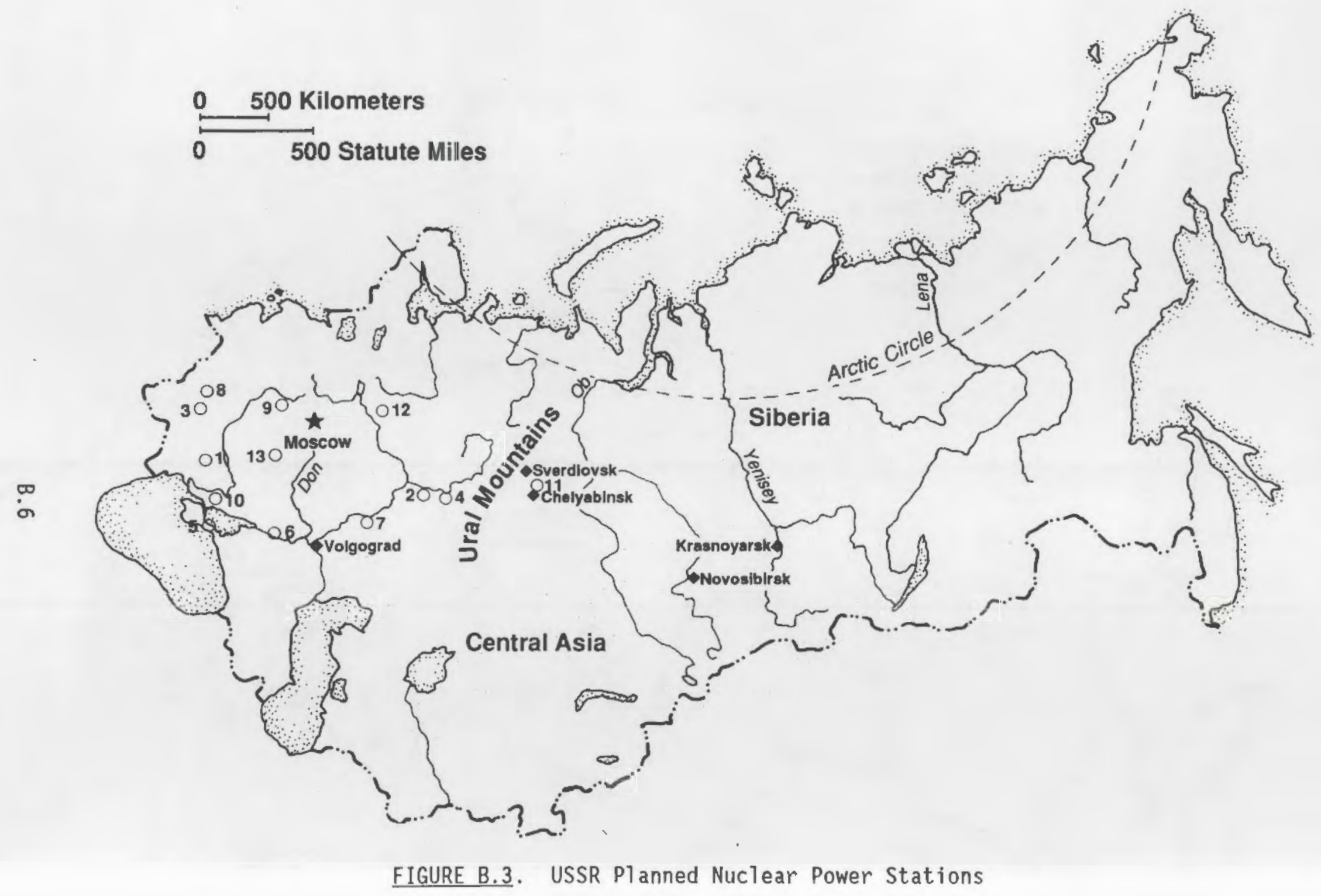




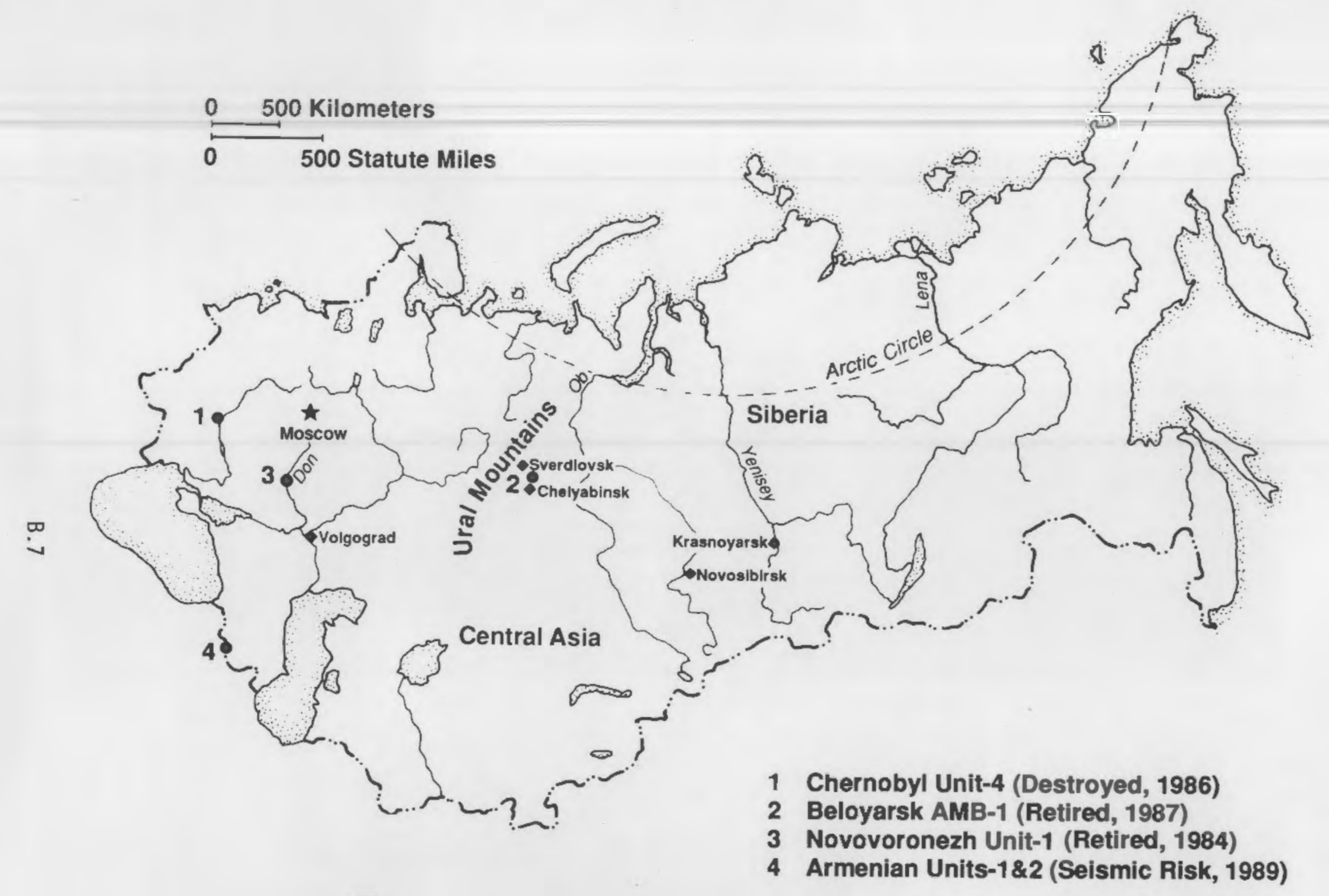

FIGURE B.4. USSR Decommissioned Nuclear Power Stations or Units 
T

II

(1)

1

$\pi$

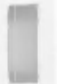

F

$\square$

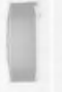

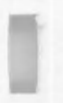

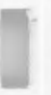

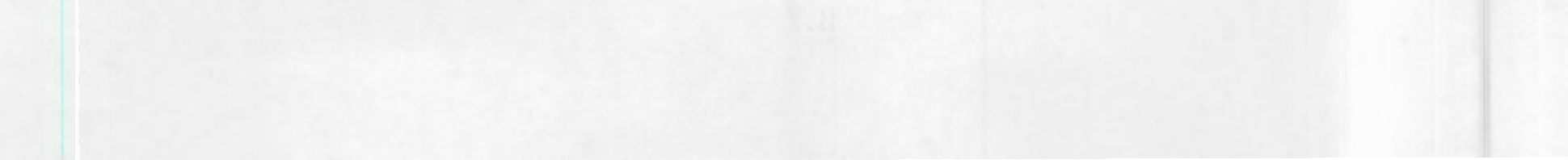




\section{APPENDIX C}

CHART OF SOVIET WASTE MANAGEMENT ACTIVITIES ACROSS THE NUCLEAR FUEL CYCLE 
FIGURE C.1. Chart of Soviet waste Management Activities Across the Nuclear Fuel Cycle

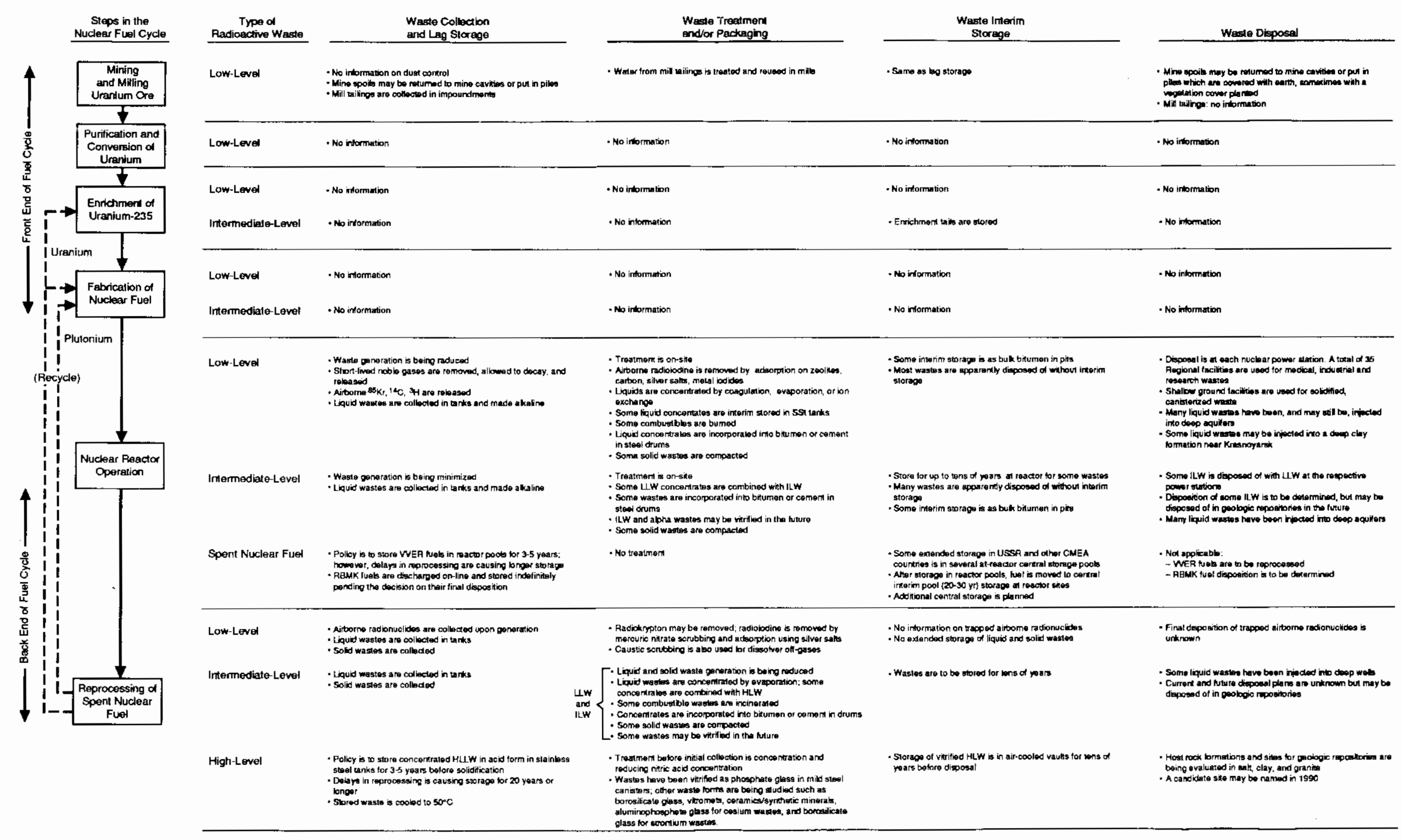



At-reactor storage, 5.6, 6.1, 6.5

Calciner, $2.4,8.5,8.7,8.8,8.11,8.12,8.15$

Canister, 8.1, 8.9, 8.14

Cask, xvi, 6.1, 6.2, 6.8, 6.9, 6.11, 6.12, 7.6, $11.2-11.6$

Central storage, $6.1,6.8,6.11, \mathrm{C} .1$

Container, $7.6,8.6,8.9,8.11,8.13-8.15,8.24$, 11.2

Decontamination, $x v i, 2.4,5.4,5.5,6.11,6.13$, $6.22,6.23,7.8,8.5,8.28,8.29,9.2,9.3,9.5,9.6$, $9.8,11.5$

Decontamination station, 2.4, 9.5, 9.6, 9.8

Enrichment $x$ vi, 2.3, 3.1, 3.3, 4.1, 4.3, 6.3, 6.6, $6.13,6.14$, A.1, A.16, A.19, A.20, A.22, A.24, A. $27-A .30$, A.38

Fast breeder reactor, FBR or BN, 6.1, 6.3, 6.6, $6.7,7.2$ 7.3, 7.8, 8.12, 8.17, A.7-A.9, A.15, A.35-A.37, A.42, A.46, A.48, A.51, A.52

GAEN, ix, 2.2, 3.3, 5.1, A.2-A.4

GKAE, ix, 2.1, 3.3, 3.4, 6.21, 10.2, 10.3, 10.12, A. 2, A. 15, A. 18, A. 20

High-level waste or HLW, iii, iv, v, 1.1, 1.3, 2.4, 3.5, 7.1. 7.6, Section 8, 9.2, 9.11, 10.1-10.7, 10.2, $10.4,10.15, \mathrm{C} .1$

Incineration, 9.4, 9.10

Injection, iv, 1.1, 5.1, 9.1, 9.8, 9.9, 10.1, 10.3, 10.10-10.12, 10.15, A.41

Intermediate-level waste or ILW, $v, 1.1,1.3$, 2.4, 8.15, 8.17, Section 9, 10.1, 10.3, 10.4, 10.8, $10.12,10.14,10.15,11.7$, A.14, C. 1 lon-exchange, $5.4,5.5,7.4,9.4,9.5, \mathrm{~A} .25, \mathrm{C} .1$

Low-level waste or LLW, 1.1, 1.3, 1.4, 5.1, 5.3, 5.5. Section 9, 10.1, 10.3, 10.4, 10.8, 10.13-10.15, A.20, C.1

Melter, iv, 2.4, 7.6, 8.1, 8.5-8.10, 8.12-8.15, 8.17, $8.18,9.11$

Melter electrode, $8.6,8.14,8.16,11.5$

Quality assurance, 5.7, 11.6, A.9, A.10, A.43

Radionuclide migration, 10.11

RBMK Reactor, iii, ix, 5.1, 5.3-5.5, 6.2-6.4, 6.6, $6.11-6.14,7.1,7.3,7.7,9.1-9.3,10.12,10.14$, 11.2, 11.4, A.8, A.9, A.32, A.35, A.39, A.40, A.44, A. $46-A .48$, A. $50-A .52$

Repository, iv, $v, 1.1,3.1,5.3,5.5,8.1,8.7,8.18$, $10.2-10.7,10.12$

Reprocessing, iii, iv, $1.1,6.1,6.2,6.7,7.1-7.10$, $8.1,8.2,8.4,8.6,8.12,8.17-8.19,8.22,8.25$, $8.26,8.28,9.3,9.4,9.8,9.9,10.12,10.15$, 11.4-11.6, A.1, A.9, A.12, A.13, A.20, A.30, A.36, C.1

Solidification, iv, 1.1, 1.3, 2.4, 8.2, 8.5-8.8, 8.11, $8.13,8.17,8.19,9.4,9.8-9.11$

Spent fuel, iii, 1, 3.2, 3.3, 4.1, 6.1-6.12, 7.1-7.4, $7.6,7.8,7.10,8.1,8.4,8.12,10.12,11.1-11.6$, A.9, A.13, A.17, C. 1

Transportation, 5.2, 6.11, 6.12, 8.7, 10.1-10.4, 11.i-11.7, A.27

Vitrification, iv, 2.4, 3.5, 5.1, 5.6, 8.1, 8.2, $8.5-8.12,8.14,8.15,8.18,8.19,9.1,9.5,9.10$, $9.1 \%, 10.15$

VVER Reactor, iii, ix, 3.3, 5.1, 5.4, 5.5, 6.1-6.5, $6.7,6.8,6.10-6.12,7.1,7.2,7.4,7.6,7.7,8.4$, $8.12,8.17,8.19,9.2,9.3,11.2-11.4,11.6$, A.8. A.9, A.17, A.32-A.34, A.39-A.41, A.44, A.46-A.48, A.50-A.52 
Waste forms, $2.4,5.3,8.8,10.14,10.15, \mathrm{C} .1$

Bitumen, iv, 5.1, 5.2-5.4, 5.6, 5.5, 9.1, $9.4-9.11,10.4,10.12-15$, C.1

Cement, 5.5, 5.6, 9.4, 9.7, 9.8, 9.10, 9.11, 10.6, 10.14, C.1

Ceramic, 7.4, 7.7, 8.1, 8.5, 8.8-8.13, 8.16-8.18, 9.11, C.1

Glass, iv, 2.4, 5.4, 7.6, 8.1, 8.5-8.9, $8.11-8.16,8.18,8.28,9.5,9.7,9.8,9.11$, $10.1,10.4,10.14,10.15$

Metal matrix, 8.1, 8.4, 8.13, 10.13

Polymers, 9.5, 9.10

Waste minimization, $\mathrm{N}, 9.1$ 